\title{
Dietary proteins and blood pressure regulation
}

Citation for published version (APA):

Teunissen-Beekman, K. F. M. (2015). Dietary proteins and blood pressure regulation. [Doctoral Thesis, Maastricht University]. Uitgeverij BOXPress. https://doi.org/10.26481/dis.20150123kt

Document status and date:

Published: 01/01/2015

DOI:

$10.26481 /$ dis.20150123kt

Document Version:

Publisher's PDF, also known as Version of record

\section{Please check the document version of this publication:}

- A submitted manuscript is the version of the article upon submission and before peer-review. There can be important differences between the submitted version and the official published version of record.

People interested in the research are advised to contact the author for the final version of the publication, or visit the DOI to the publisher's website.

- The final author version and the galley proof are versions of the publication after peer review.

- The final published version features the final layout of the paper including the volume, issue and page numbers.

Link to publication

\footnotetext{
General rights rights.

- You may freely distribute the URL identifying the publication in the public portal. please follow below link for the End User Agreement:

www.umlib.nl/taverne-license

Take down policy

If you believe that this document breaches copyright please contact us at:

repository@maastrichtuniversity.nl

providing details and we will investigate your claim.
}

Copyright and moral rights for the publications made accessible in the public portal are retained by the authors and/or other copyright owners and it is a condition of accessing publications that users recognise and abide by the legal requirements associated with these

- Users may download and print one copy of any publication from the public portal for the purpose of private study or research.

- You may not further distribute the material or use it for any profit-making activity or commercial gain

If the publication is distributed under the terms of Article $25 \mathrm{fa}$ of the Dutch Copyright Act, indicated by the "Taverne" license above, 


\section{DIETARY PROTEINS AND BLOOD PRESSURE REGULATION}

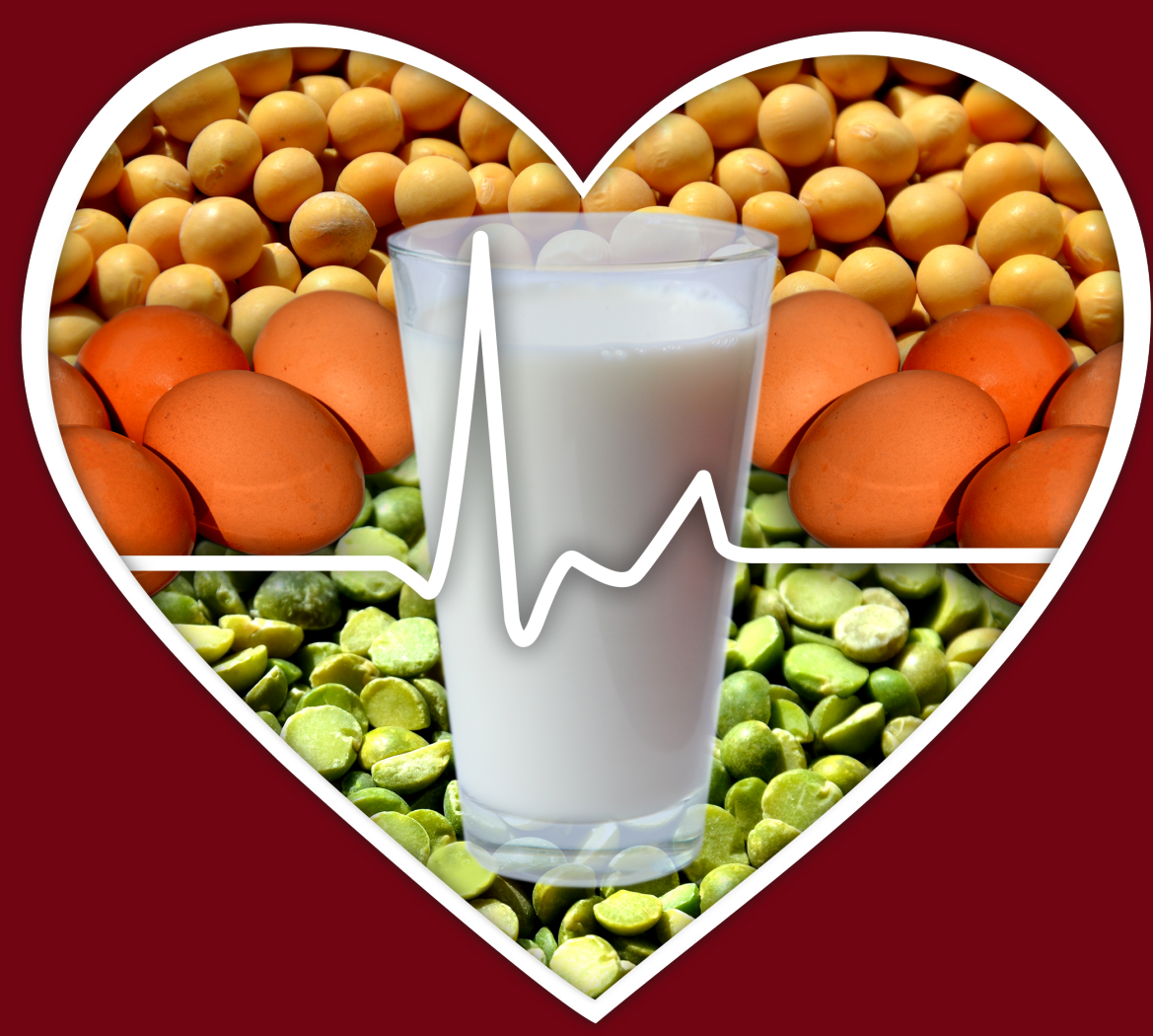

Karianna Teunissen-Beekman 


\section{Dietary proteins and blood pressure regulation}

Karianna Teunissen-Beekman 


\section{TIFOOD Outrim NUTRITION I IULIII II}

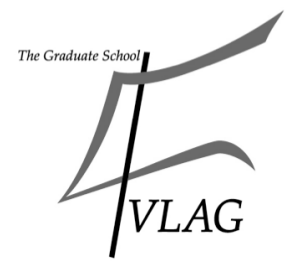

The studies presented in this thesis were performed within the framework of TI Food and Nutrition and within NUTRIM, School for Nutrition, Toxicology and Metabolism, which participates in the Graduate School VLAG (Food, Technology, Agrobiotechnology, Nutrition and HEalthy Sciences), accredited by the Royal Netherlands Academy of Arts and Sciences.

Cover design: Karianna Teunissen-Beekman, Paul Teunissen en proefschriftmaken.nl Lay-out: Karianna Teunissen-Beekman

Printed by: Proefschriftmaken.nl || Uitgeverij BOXPress

Published by: Uitgeverij BOXPress, 's-Hertogenbosch

(C) Copyright Karianna Teunissen-Beekman, Maastricht 2015

ISBN 978-94-6295-041-2 


\title{
Dietary proteins and blood pressure regulation
}

\author{
PROEFSCHRIFT \\ Ter verkrijging van de graad van doctor \\ aan de Universiteit Maastricht, \\ Op gezag van de Rector Magnificus, \\ Prof. dr. L.L.G. Soete, \\ Volgens het besluit van het College van Decanen, \\ In het openbaar te verdedigen \\ Op vrijdag 23 januari 2015 om 10.00 uur \\ door \\ Karianna Francisca Maria Beekman
}

Geboren te Cadier en Keer op 17 februari 1983 


\section{PROMOTORES}

Prof. dr. M.A. van Baak

Prof. dr. P.W. de Leeuw

\section{BEOORDELINGSCOMMISSIE}

Prof. dr. R.P. Mensink (voorzitter)

Prof. I.A. Macdonald (University of Nottingham, United Kingdom)

Prof. dr. H.A.J. Struijker Boudier

Dr. P. Zock (Unilever R\&D, Vlaardingen)

Financial support from the Dutch Heart Foundation for the publication of this thesis is gratefully acknowledged.

Financial support from the Netherlands Association for the Study of Obesity (NASO) for publication of this thesis is gratefully acknowledged. 


\section{TABLE OF CONTENTS}

List of abbreviations $\quad 6$

Chapter 1 General Introduction 9

Chapter 2 The role of dietary protein in blood pressure regulation $\quad 19$ Curr Opin Lipidol. 2013 Feb; 24(1):65-70

Chapter 3 Protein supplementation lowers blood pressure in overweight adults: effect of dietary proteins on blood pressure (PROPRES), a randomized trial

Am J Clin Nutr. 2012 Feb 22;95(4):966-71

Chapter 4 Blood pressure decreases more after high-carbohydrate meals than after high-protein meals in overweight adults with elevated blood pressure, but there is no difference after 4 weeks of consuming a carbohydrate-rich or protein-rich diet

J. Nutr. 2013 Apr; 143(4):424-9

Chapter 5 Differential effects of proteins and carbohydrates on 69 postprandial blood pressure-related responses

Br J Nutr. 2014, 112: 600-8

Chapter 6 Effects of dietary proteins and carbohydrates on markers of 89 endothelial function and low-grade inflammation

$\begin{array}{lll}\text { Chapter } 7 & \text { Effect of increased protein intake on renal acid load and renal } & 107\end{array}$ hemodynamic responses

$\begin{array}{lll}\text { Chapter } 8 & \text { General discussion } & 123\end{array}$

Summary $\quad 139$

Summary in Dutch (Samenvatting) 143

$\begin{array}{ll}\text { Valorization } & 147\end{array}$

Acknowledgements (Dankwoord) 155

$\begin{array}{ll}\text { Curriculum Vitae } & 161\end{array}$

List of publications $\quad 163$ 


\section{LIST OF ABBREVIATIONS}

ACE angiotensin converting enzyme

ADMA asymmetric dimethylarginine

Alx

augmentation index

$\mathrm{BP}$

blood pressure

CO cardiac output

CRP

C-reactive protein

CVD

cardiovascular disease

DASH

dietary approaches to stop hypertension

DBP

diastolic blood pressure

$\mathrm{E}$

epinephrine

ECV

extracellular volume

ED

endothelial dysfunction

eGFR

estimated glomerular filtration rate

ERPF

effective renal plasma flow

ESC

European Society of Cardiology

ESH

European Society of Hypertension

FBF

forearm blood flow

$\mathrm{FF}$

filtration fraction

FMD

flow-mediated dilation

GFR

glomerular filtration rate

GIP

Glucose-dependent insulinotropic polypeptide

GLP-1

glucagon-like peptide-1

$\mathrm{HC}$

high carbohydrate

HP

high protein

HR

heart rate

IL-6

interleukin 6

LGI

low-grade inflammation

MAP

mean arterial pressure

MDRD

modification of diet in renal disease

MSNA

muscle sympathetic nerve activity

NE

norepinephrine

NO

nitric oxide

NOCs

$\mathrm{N}$-nitroso compounds

NOx

nitrite, nitroso compounds (RXNO) and S-nitrosothiols

$\mathrm{PAH}$

para-aminohippurate 


$\begin{array}{ll}\text { PAI-1 } & \text { plasminogen activator inhibitor-1 } \\ \text { PP } & \text { pulse pressure } \\ \text { PROPRES } & \text { randomized clinical trial on the effects of PROteins on blood PRESsure } \\ \text { PWA } & \text { pulse wave analysis } \\ \text { PWV } & \text { pulse wave velocity } \\ \text { RAAS } & \text { renin-angiotensin-aldosterone system } \\ \text { RBF } & \text { renal blood flow } \\ \text { RVR } & \text { renal vascular resistance } \\ \text { SAA } & \text { serum amyloid A } \\ \text { SBP } & \text { systolic blood pressure } \\ \text { SE-selectin } & \text { soluble endothelial selectin } \\ \text { SICAM } & \text { soluble intercellular adhesion molecule 1 } \\ \text { SNS } & \text { sympathetic nervous system } \\ \text { SV } & \text { stroke volume } \\ \text { SVCAM } & \text { soluble vascular cell adhesion molecule 1 } \\ \text { TPR } & \text { total peripheral resistance } \\ \text { TNFa } & \text { tumor necrosis factor a } \\ \text { UPRAL } & \text { urinary potential renal acid load } \\ \text { VWf } & \text { von Willebrand factor }\end{array}$





\section{Chapter 1}

General introduction 


\section{HYPERTENSION}

Cardiovascular diseases (CVD) are responsible for $30 \%$ of all deaths world wide (1). In the Netherlands, CVD were the second major cause of mortality, accounting for $28 \%$ of deaths in 2012 (2). One of the risk factors for CVD is hypertension (1,3,4). Over $25 \%$ of adults world-wide was estimated to have hypertension in the year 2000 (4). Prehypertension (systolic blood pressure (SBP) 120-139 mmHg, diastolic blood pressure (DBP) 80-89 $\mathrm{mmHg}$ ) also increases the risk for myocardial infarction and coronary artery disease (5). One way to reduce blood pressure (BP) is by use of medication (6). However, for individuals with prehypertension, it is unknown whether medication reduces CVD risk. Because prehypertensive individuals are often relatively young and at low risk, the question remains whether they should use medication at all (7). Current guidelines from the European Society of Hypertension (ESH) and European Society of Cardiology (ESC) state that individuals with SBP $<140 \mathrm{mmHg}$ and DBP $<90 \mathrm{mmHg}$ should not be treated with medication (8). Depending on their BP and the number of other risk factors for CVD, individuals with higher BP should first start with lifestyle changes before starting with BPlowering medication. These lifestyle changes include dietary advices, like restriction of salt intake, which have been proven to reduce BP (8). The dietary approaches to stop hypertension (DASH) diet, with plenty of fruits and vegetables, low-fat dairy foods and reduced saturated fat, was found to lower BP compared to a control diet with less fruit and vegetables, low-fat dairy and more saturated fat $(9,10)$. Another food source hypothesized to be effective in lowering BP is dietary protein. A large controlled feeding crossover trial showed that BP decreased when carbohydrate-rich foods in the diet were replaced by protein-rich foods (11).

High protein diets are often prescribed to overweight and obese individuals for weight loss because of the satiating and fat free mass sparing effects of dietary proteins (12). At least $75 \%$ of the incidence of hypertension is related to obesity (3). In addition, visceral obesity and hypertension are both included in the definition criteria of the metabolic syndrome (13).

One possible mechanism linking hypertension and obesity is insulin resistance, which is also a characteristic of the metabolic syndrome (13). Hyperinsulinemia, an impaired baroreflex and dysfunctional hormonal mechanisms may result in obesity-related sympathetic overdrive, and consequently an increased BP (figure 1) (14). Reninangiotensin-aldosterone system activity is also increased in obesity. As a consequence, aldosterone levels are increased in obese individuals, which induces water and salt retention resulting in increased blood volume and BP (figure 1)(3). Since obesity often goes together with hypertension, high protein diets may have additional benefits for this particular group, independent of weight changes, because of their BP lowering effects. 


\section{DIETARY PROTEINS}

Proteins are polymers of amino acids, which are characterized by the presence of an amino $\left(-\mathrm{NH}_{2}\right)$ and an acid group $(-\mathrm{COOH})$ (15). Although over 300 amino acids exist in nature, only 20 amino acids are built into proteins (15). They can be classified as essential, non-essential or conditionally essential. Nutritionally essential amino acids need to be consumed in the diet, because the body cannot synthesize these de novo in sufficient amounts. Non-essential amino acids can be synthesized in sufficient amounts by the body. Conditionally essential amino acids are essential under special circumstances, for instance during pregnancy, when utilization exceeds synthesis rates (15). A newer classification system also refers to functional amino acids, which are involved in important metabolic pathways to improve health, survival, growth, development, lactation and reproduction of organisms. All three categories mentioned before contain functional amino acids (16).

On average, energy intake in a general Dutch diet consists of $45 \%$ carbohydrates, $16 \%$ proteins, $34 \%$ fat and $5 \%$ other energy containing nutrients like alcohol, fiber and organic acids (17). For instance, a 40-year-old woman weighing $75 \mathrm{~kg}$ with a sedentary life style and an energy need of $2000 \mathrm{kcal}$ per day would typically consume $79 \mathrm{~g}$ protein per day. Intake of $0.83 \mathrm{~g}$ protein per $\mathrm{kg}$ body weight is the recommended daily allowance for protein intake to remain in nitrogen balance (18). Hence, the recommended daily allowance for this woman, weighing $75 \mathrm{~kg}$, would be 62 grams of protein per day. Thus, protein consumption in a general Dutch diet is sufficient to remain in nitrogen balance. Dietary protein intake originates from different food sources. Proteins are usually present in higher amounts and quality in animal food sources like meat, eggs and milk compared to plant sources. Legumes, like beans, peas and lentils are the most protein-rich plant sources. Few plant sources contain sufficient amounts of all indispensible amino acids. The protein quality of a vegetarian diet can be increased by consuming combinations of different plant sources (19). In the Netherlands, the main food sources of dietary proteins are meat, dairy products and cereals. About $60 \%$ of protein intake originates from animal food sources (17). Health effects of dietary proteins may be dependent on whether they originate from animal or plant foods. A recently published systematic review concluded that available evidence suggests an inverse relationship between vegetable protein intake and $\mathrm{BP}$, but is inconclusive regarding the effects of total and animal protein intake on $\mathrm{BP}$ (18). However, only studies that investigated effects of food products were included in this review (18). One problem with increasing the intake of protein-rich foods is that measured health effects could also be a consequence of beneficial or adverse effects of other macro- and micronutrients present in the food products. For instance, increased low-fat dairy intake can reduce the risk for elevated BP because of the presence of bioactive milk peptides but also because of a high content of calcium, vitamin $D$, 
magnesium, and potassium $(20,21)$. When studying the effect of protein intake on BP, bias by other nutrients can be controlled better when protein intake is increased with protein isolates. Protein isolates are the purest sources of dietary protein. For instance, whey protein isolate and soy protein isolate consist of at least $90 \%$ protein (22). However, even protein isolates are not $100 \%$ pure and may also contain small amounts of bioactive compounds, which underlines the importance of taking comparable amounts of bioactive nutrients not under investigation in the protein group and in the control group into account. It has been suggested that different food processing methods may also influence metabolic effects of nutrients. For instance, different processing methods of soybean may alter isoflavone content, fiber, fat, sugars, phytic acid, and saponin (23). However, in a crossover trial, BP and other cardiovascular risk factors did not differ between 6-week diets containing either soybean, soy flour, soymilk, or animal proteins (23). In contrast, a crossover trial testing postprandial changes in insulin and glucagon after different amounts of intact and hydrolyzed soy protein and whey protein found that soy protein isolate induced a larger insulin and glucagon response, expressed as area under the curve, compared to the hydrolyzed form, while hydrolyzed and intact whey protein did not differ in insulin and glucagon responses (24). Another difficulty when investigating effects of macronutrients on health is that a combination of macronutrients has to be consumed. Increasing intake of one macronutrient has to be combined with decreased intake of another macronutrient in order to maintain energy balance. Therefore, it is never certain whether health effects are the result of increased intake of one macronutrient or decreased intake of one of the other macronutrients.

\section{DIETARY PROTEINS AND BLOOD PRESSURE REGULATION}

From a hemodynamic point of view, BP is determined by total peripheral resistance (TPR) and cardiac output (CO) (figure 1). $\mathrm{CO}$ is the product of heart rate (HR) and stroke volume (figure 1). TPR is determined by the sum of resistances from all blood vessels. Vasoconstriction reduces the diameter of a blood vessel and thereby increases BP, while vasodilation has the opposite effect (figure 1). Homeostatic regulation of these variables depends on several mechanisms. Some of these BP regulation mechanisms may be modulated by peptides $(25,26)$ and amino acids $(27)$.

When a decrease in BP is sensed by baroreceptors in the aortic arch and carotid sinuses, the central nervous system will respond with an increase in sympathetic nervous system activity, which, amongst stress, results in an increased HR and heart muscle contractility. A protein load induces a smaller postprandial increase in muscle sympathetic nerve activity (MSNA) compared to a carbohydrate load (28). Therefore, dietary proteins may lower BP more compared to carbohydrates because they induce a smaller postprandial increase in 
sympathetic activity (29). Insulin induces increased SNS activity $(30,31)$ and CO $(32,33)$ and may increase BP via this pathway. On the other hand, insulin also induces nitric oxide (NO)-dependent vasodilation (31), which results in lower TPR and decreased BP. Since dietary proteins and amino acids are insulinotropic $(34,35)$, these may affect BP via increased insulin concentrations. However, in healthy humans the opposing vasoconstrictor and vasodilator effects of insulin will have a minimal net effect on BP (36). Vasodilation can be brought about via NO-dependent pathways or NO-independent pathways (figure 1), for example via the release of other endothelium-derived relaxing factors $(37,38)$. NO bioavailability can be directly improved by dietary proteins, because the amino acid arginine is a precursor of NO (39). A recent meta-analysis of randomized placebo-controlled trials showed that oral arginine supplementation overall lowered BP (40).

Responsiveness of the endothelium to vasodilator or vasoconstrictor stimuli can be reduced by endothelial dysfunction (ED). The endothelium is the active inner layer of blood vessels, which normally decreases vascular tone, leukocyte adhesion, inflammatory activity and platelet aggregation while maintaining vascular permeability to nutrients, hormones etcetera. ED is present when the endothelium functions inappropriately in resting conditions or after stimulation (41) and is associated with hypertension $(3,42)$. Flow-mediated dilation (FMD) is a very popular technique to measure endothelial/vascular function because it is non-invasive and relatively easy to perform. The technique measures changes in the diameter of the brachial artery in response to reactive hyperemia. FMD is considered to be proportional to endothelial function. Because of a lack of standardization, measurements are difficult to compare between studies (38). Another way to assess ED is by measuring the release of biomarkers of ED and low-grade inflammation (LGI) (43) (figure 1). In an early phase of inflammation plasma levels of the LGI markers i.e. C-reactive protein (CRP) and serum amyloid A (SAA), are increased (44). Pro-inflammatory stimuli activate endothelial cells, which then increase their expression of adhesion molecules like soluble intercellular adhesion molecule 1 (sICAM), soluble vascular adhesion molecule 1 (sVCAM) and soluble E-selectin (sE-selectin) (45, 46). Increased levels of von Willebrand factor (vWf) indicate prothrombotic and procoagulant activity of the endothelium and are therefore considered as a marker of $\operatorname{ED}(41,46)$.

Another pathway through which dietary proteins can reduce TPR is via the release of vasoactive hormones like insulin, glucagon-like peptide-1 (GLP-1) and glucagon. Dietary proteins induce release of GLP-1 (47), which could reduce BP via both NO-dependent and NO-independent mechanisms (48). Glucagon is also increased by protein intake (34) and this hormone may reduce BP via its vasodilator effects (49). However, mechanisms through which glucagon induces vasodilation are not clear. One more way via which dietary proteins may reduce $\mathrm{BP}$ is through modulation of the renin-angiotensin- 
aldosterone system (RAAS) (figure 1) (50). Medication targeting ACE improves ED by increasing NO levels and lowering levels of the vasoconstrictors endothelin-1 and angiotensin II (51). Dietary proteins could also influence the volume of blood present in the circulation. Dietary proteins are able to affect kidney function, since several studies have reported an increased glomerular filtration rate (GFR) after consumption of a protein load (52)(figure 1). The kidneys are also involved in long-term BP regulation because of their role in maintaining blood volume. Renin release from juxtaglomerular cells in the afferent arterioles in the kidneys is stimulated by decreased renal perfusion, decreased delivery of chloride to the macula densa or by sympathetic nerve stimulation (53). Renin is an enzyme involved in the formation of angiotensin I from angiotensinogen, which is released from the liver. ACE is involved in the formation of angiotensin II from angiotensin I. Angiotensin II is not only a strong vasoconstrictor but it also stimulates aldosterone, which induces sodium and water retention resulting in an increased CO (figure 1) (51).

\section{AIMS AND OUTLINE OF THE THESIS}

Hypertension is a global problem and one way to reduce the incidence and prevalence of hypertension may be via increased protein intake. The research question to be answered is the present thesis is: "Does protein intake affect blood pressure?" and "Do dietary proteins influence blood pressure by affecting SNS activity, humoral mechanisms, endothelial function, the RAAS, and/or kidney function?"

First, an overview of current literature on the effect of dietary proteins on BP will be discussed (chapter 2). Next, the effect of 4 weeks of increased protein intake versus maltodextrin intake on BP has been studied in overweight and obese individuals with untreated elevated BP in a randomized controlled trial (chapter 3). In a subgroup of trial participants, the acute effects of meals supplemented with dietary protein and maltodextrin on 12-hour postprandial hemodynamics (chapter 4) and endothelial function (Chapter 6) were investigated. In a follow-up study, the postprandial effects of proteins and carbohydrates isolated from different food sources on 4-hour postprandial hemodynamics, hormones (Chapter 5) and endothelial function (chapter 6) were examined. Finally, the effects of 4 weeks increased protein intake on renal acid load and fasting and postprandial renal function and the renin-angiotensin-aldosterone system were studied (Chapter 7). The main results and conclusions of the studies described in chapter 2-7 are discussed in chapter 8 , which is concluded with implications for future research. 


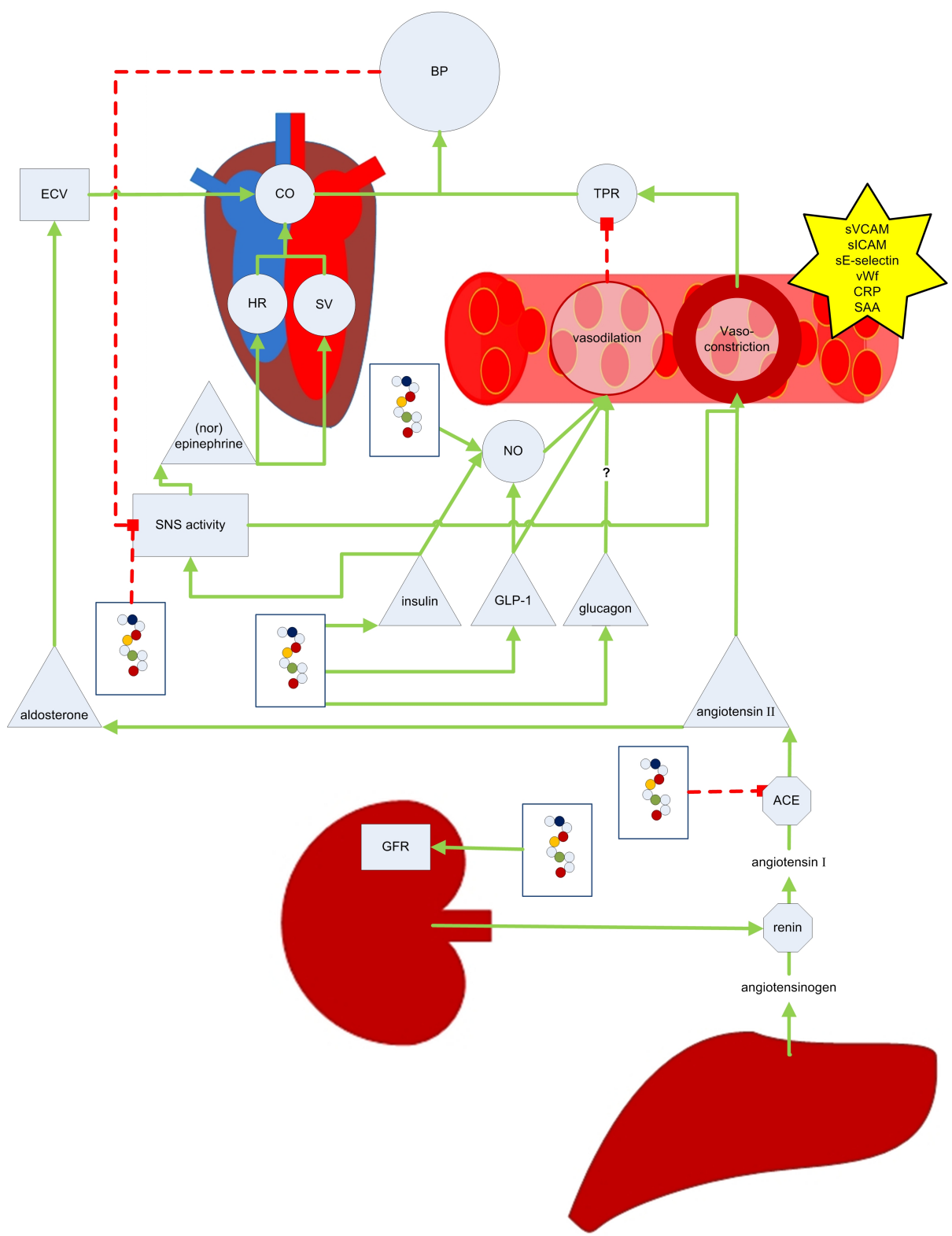

Figure 1. Effects of dietary proteins on blood pressure regulation

Proteins are depicted as multicolored chains composed of different amino acids. Green lines ending with an arrow indicate a stimulating effect. Red dotted lines ending in a square indicate an inhibitory effect.

Abbreviations: ACE, angiotensin converting enzyme; BP, blood pressure; ECV, extracellular volume; GFR, glomerular filtration rate, CO, cardiac output; CRP, C-reactive protein; GLP-1, Glucagon-like peptide-1; HR, heart rate; NO, nitric oxide; $\mathrm{SE}$-selectin, soluble E-selectin; sICAM, soluble intercellular adhesion molecule 1 ; SVCAM, soluble vascular molecule; SNS, sympathetic nervous system; TPR, total peripheral resistance; vWf, von Willebrand factor. 


\section{REFERENCES}

1. Deaton C, Froelicher ES, Wu LH, Ho C, Shishani K, Jaarsma T. The global burden of cardiovascular disease. J Cardiovasc Nurs. 2011;26(4 Suppl):S5-14.

2. Vaartjes I, Koopman C, van Dis I, Visseren FL, Bots ML. Hart- en vaatziekten in Nederland 2013, cijfers over leefstijl, risicofactoren, ziekte en sterfte. 2013. Available from: https://http://www.hartstichting.nl/downloads/cijferboek-2013.

3. Landsberg L, Aronne LJ, Beilin LJ, Burke V, Igel LI, Lloyd-Jones D, et al. Obesity-related hypertension: Pathogenesis, cardiovascular risk, and treatment-A position paper of the The Obesity Society and the American Society of Hypertension. Obesity (Silver Spring). 2013;21(1):8-24.

4. Kearney PM, Whelton M, Reynolds K, Muntner P, Whelton PK, He J. Global burden of hypertension: analysis of worldwide data. Lancet. 2005;365(9455):217-23.

5. Qureshi Al, Suri MF, Kirmani JF, Divani AA, Mohammad Y. Is prehypertension a risk factor for cardiovascular diseases? Stroke; a journal of cerebral circulation. 2005;36(9):1859-63.

6. Turnbull F. Effects of different blood-pressure-lowering regimens on major cardiovascular events: results of prospectively-designed overviews of randomised trials. Lancet. 2003;362(9395):1527-35.

7. McInnes GT. Drug treatment of prehypertension: Not now, not ever? Blood Press. 2009;18(6):304-7.

8. Mancia G, Fagard R, Narkiewicz K, Redón J, Zanchetti A, Böhm M, et al. 2013 Practice guidelines for the management of arterial hypertension of the European Society of Hypertension (ESH) and the European Society of Cardiology (ESC): ESH/ESC Task Force for the Management of Arterial Hypertension. J Hypertens. 2013;31(10):1925-38.

9. Appel LJ, Moore TJ, Obarzanek E, Vollmer WM, Svetkey LP, Sacks FM, et al. A clinical trial of the effects of dietary patterns on blood pressure. DASH Collaborative Research Group. $N$ Engl J Med. 1997;336(16):1117-24

10. Lin PH, Allen JD, Li YJ, Yu M, Lien LF, Svetkey LP. Blood Pressure-Lowering Mechanisms of the DASH Dietary Pattern. J Nutr Metab. 2012;2012:472396.

11. Appel LJ, Sacks FM, Carey VJ, Obarzanek E, Swain JF, Miller ER, 3rd, et al. Effects of protein, monounsaturated fat, and carbohydrate intake on blood pressure and serum lipids: results of the OmniHeart randomized trial. Jama. 2005;294(19):2455-64.

12. Fromentin G, Darcel N, Chaumontet C, Marsset-Baglieri A, Nadkarni N, Tome D. Peripheral and central mechanisms involved in the control of food intake by dietary amino acids and proteins. Nutrition research reviews. 2012;25(1):29-39.

13. Wiernsperger N, Nivoit P, De Aguiar LG, Bouskela E. Microcirculation and the metabolic syndrome. Microcirculation. 2007;14(4-5):403-38.

14. Grassi G. Sympathetic overdrive and cardiovascular risk in the metabolic syndrome. Hypertens Res. 2006;29(11):839-47.

15. Wu G. Amino acids: metabolism, functions, and nutrition. Amino Acids. 2009;37(1):1-17.

16. Wu G. Functional amino acids in nutrition and health. Amino Acids. 2013;45(3):407-11.

17. van Rossum CTM, Fransen HP, Verkaik-Kloosterman J, Buurma-Rethans EJM, Ocké MC. Dutch national food consumption survey 2007-2010: Diet of children and adults aged 7 to 69 years. RIVM rapport 350050006/2011 [Internet]. 2011 [cited 2014 May 26]:[148 p.]. Available from: http://www.rivm.nl/dsresource?objectid=rivmp:55436\&type=org\&disposition=inline\&ns_nc=1.

18. Pedersen AN, Kondrup J, Borsheim E. Health effects of protein intake in healthy adults: a systematic literature review. Food Nutr Res. 2013;57.

19. Watford M, Wu G. Protein. Advances in nutrition (Bethesda, Md). 2011;2(1):62-3

20. Ralston RA, Lee JH, Truby H, Palermo CE, Walker KZ. A systematic review and meta-analysis of elevated blood pressure and consumption of dairy foods. J Hum Hypertens. 2012;26(1):3-13. 
21. Chrysant SG, Chrysant GS. An update on the cardiovascular pleiotropic effects of milk and milk products. J Clin Hypertens (Greenwich). 2013;15(7):503-10.

22. Hoffman JR, Falvo MJ. Protein - Which is Best? Journal of sports science \& medicine. 2004;3(3):118-30.

23. Matthan NR, Jalbert SM, Ausman LM, Kuvin JT, Karas RH, Lichtenstein AH. Effect of soy protein from differently processed products on cardiovascular disease risk factors and vascular endothelial function in hypercholesterolemic subjects. Am J Clin Nutr. 2007;85(4):960-6.

24. Claessens $M$, Saris WH, van Baak MA. Glucagon and insulin responses after ingestion of different amounts of intact and hydrolysed proteins. Br J Nutr. 2008;100(1):61-9.

25. Raybould HE, Glatzle J, Freeman SL, Whited K, Darcel N, Liou A, et al. Detection of macronutrients in the intestinal wall. Autonomic neuroscience : basic \& clinical. 2006;125(1-2):28-33.

26. Sartor DM. Sympathoinhibitory signals from the gut and obesity-related hypertension. Clinical autonomic research : official journal of the Clinical Autonomic Research Society. 2013;23(1):33-9.

27. Vasdev S, Stuckless J. Antihypertensive effects of dietary protein and its mechanism. Int J Angiol. 2010;19(1):e7-e20.

28. Fagius J, Berne C. Increase in muscle nerve sympathetic activity in humans after food intake. Clin Sci (Lond). 1994;86(2):159-67.

29. Fagius J. Sympathetic nerve activity in metabolic control--some basic concepts. Acta Physiol Scand. 2003;177(3):337-43.

30. Landsberg L. Insulin-mediated sympathetic stimulation: role in the pathogenesis of obesity-related hypertension (or, how insulin affects blood pressure, and why). J Hypertens. 2001;19(3 Pt 2):523-8.

31. Scherrer U, Sartori C. Insulin as a vascular and sympathoexcitatory hormone: implications for blood pressure regulation, insulin sensitivity, and cardiovascular morbidity. Circulation. 1997;96(11):4104-13.

32. Baron $A D$, Brechtel $G$. Insulin differentially regulates systemic and skeletal muscle vascular resistance. Am J Physiol. 1993;265(1 Pt 1):E61-7.

33. Russell RR, 3rd, Chyun D, Song S, Sherwin RS, Tamborlane WV, Lee FA, et al. Cardiac responses to insulin-induced hypoglycemia in nondiabetic and intensively treated type 1 diabetic patients. Am J Physiol Endocrinol Metab. 2001;281(5):E1029-36.

34. Claessens $M$, Calame W, Siemensma AD, van Baak MA, Saris WH. The effect of different protein hydrolysate/carbohydrate mixtures on postprandial glucagon and insulin responses in healthy subjects. Eur J Clin Nutr. 2009;63(1):48-56.

35. Gannon MC, Nuttall FQ. Amino acid ingestion and glucose metabolism--a review. IUBMB Life. 2010;62(9):660-8.

36. Muniyappa R, Montagnani M, Koh KK, Quon MJ. Cardiovascular actions of insulin. Endocrine reviews. 2007;28(5):463-91.

37. Vanhoutte PM, Shimokawa H, Tang EH, Feletou M. Endothelial dysfunction and vascular disease. Acta Physiol (Oxf). 2009;196(2):193-222.

38. Le Brocq M, Leslie SJ, Milliken P, Megson IL. Endothelial dysfunction: from molecular mechanisms to measurement, clinical implications, and therapeutic opportunities. Antioxid Redox Signal. 2008;10(9):1631-74.

39. Bode-Boger SM, Boger RH, Galland A, Tsikas D, Frolich JC. L-arginine-induced vasodilation in healthy humans: pharmacokinetic-pharmacodynamic relationship. Br J Clin Pharmacol. 1998;46(5):489-97.

40. Dong JY, Qin LQ, Zhang Z, Zhao Y, Wang J, Arigoni F, et al. Effect of oral L-arginine supplementation on blood pressure: a meta-analysis of randomized, double-blind, placebo-controlled trials. Am Heart J. 2011;162(6):959-65.

41. Schalkwijk CG, Stehouwer CD. Vascular complications in diabetes mellitus: the role of endothelial dysfunction. Clin Sci (Lond). 2005;109(2):143-59.

42. Watson T, Goon PK, Lip GY. Endothelial progenitor cells, endothelial dysfunction, inflammation, and oxidative stress in hypertension. Antioxid Redox Signal. 2008;10(6):1079-88. 
43. van Bussel BC, Henry RM, Schalkwijk CG, Ferreira I, Feskens EJ, Streppel MT, et al. Fish consumption in healthy adults is associated with decreased circulating biomarkers of endothelial dysfunction and inflammation during a 6-year follow-up. J Nutr. 2011;141(9):1719-25.

44. Zakynthinos E, Pappa N. Inflammatory biomarkers in coronary artery disease. J Cardiol. 2009;53(3):31733.

45. Badimon L, Romero JC, Cubedo J, Borrell-Pages M. Circulating biomarkers. Thrombosis research. 2012;130 Suppl 1:S12-5.

46. Tousoulis D, Papageorgiou N, Androulakis E, Siasos G, Latsios G, Tentolouris K, et al. Diabetes mellitusassociated vascular impairment: novel circulating biomarkers and therapeutic approaches. J Am Coll Cardiol. 2013;62(8):667-76.

47. Hall WL, Millward DJ, Long SJ, Morgan LM. Casein and whey exert different effects on plasma amino acid profiles, gastrointestinal hormone secretion and appetite. Br J Nutr. 2003;89(2):239-48.

48. Wang B, Ni Y, Zhong J, Sun F. Effects of incretins on blood pressure: a promising therapy for type 2 diabetes mellitus with hypertension. J Diabetes. 2012;4(1):22-9.

49. Farah AE. Glucagon and the circulation. Pharmacol Rev. 1983;35(3):181-217.

50. Boelsma E, Kloek J. Lactotripeptides and antihypertensive effects: a critical review. $\mathrm{Br} J \mathrm{Nutr}$. 2009;101(6):776-86.

51. Pacurari M, Kafoury R, Tchounwou PB, Ndebele K. The Renin-Angiotensin-Aldosterone System in Vascular Inflammation and Remodeling. International journal of inflammation. 2014;2014:689360.

52. Bernstein AM, Treyzon L, Li Z. Are high-protein, vegetable-based diets safe for kidney function? A review of the literature. J Am Diet Assoc. 2007;107(4):644-50.

53. Moon JY. Recent Update of Renin-angiotensin-aldosterone System in the Pathogenesis of Hypertension. Electrolyte \& blood pressure : E \& BP. 2013;11(2):41-5. 


\section{Chapter 2}

\section{The role of dietary protein in blood pressure regulation}

Curr Opin Lipidol. 2013 Feb; 24(1):65-70

Karianna F.M. Teunissen-Beekman Marleen A. van Baak 


\section{ABSTRACT}

Purpose of review

Despite a considerable amount of research, the blood pressure (BP) lowering effect of dietary proteins is still not fully established. This review discusses the most recent findings on BP lowering of dietary proteins and protein sources, the possible mechanisms and the safety of increasing protein intake.

\section{Recent findings}

Recent short-term, strictly controlled, randomized clinical trials show a BP lowering effect of increased protein intake. Longer-term trials, however, show inconsistent results. Because all recent trials exchanged carbohydrates, and not fats, for proteins, the question remains whether potential beneficial effects of high protein diets are due to increased protein intake or decreased carbohydrate intake. No clear differences between plant protein and animal protein are found in observational studies, and trials comparing plant versus animal protein are lacking. Different protein sources may lower BP via different mechanisms, which might explain divergent findings. Potential harms of high protein diets are not confirmed in recent trials in healthy persons.

\section{Summary}

Increasing dietary protein intake or decreasing carbohydrate intake within reasonable limits may be beneficial for BP. The most and least beneficial protein sources still need to be determined.

\section{Keywords}

Animal protein, blood pressure, plant protein, protein intake, safety 


\section{KEY POINTS}

- $\quad$ Randomized trials show BP lowering effects of dietary proteins, whereas findings in long-term studies are less clear.

- Does higher protein intake or lower carbohydrate intake lower BP? More trials comparing the hypotensive effect of protein consumption with carbohydrate or fat consumption are needed.

- Available evidence does not support a difference in hypotensive effects of plant versus animal protein intake.

- $\quad$ Acute studies give insight into BP lowering mechanisms, but findings are hard to translate into longterm effects.

\section{INTRODUCTION}

Many beneficial effects have been ascribed to dietary protein $(1,2)$. Satiating and lean body mass sparing effects make high protein diets popular in weight loss and weight management programs (3). Another favorable effect of dietary proteins may be improvement of blood pressure (BP) and cardiovascular health $(4,5)$. A systematic review of observational and intervention studies until June 2010 concluded that dietary protein may have a small beneficial effect on BP. Strongest evidence for this effect came from randomized controlled trials, which may be due to better controlled food intake and reduced risk of residual confounding in trials compared with observational studies (6). However, since the publication of this review (6), new studies have been published on the BP lowering effects of high protein diets. The most recent evidence will be discussed in this review. Beneficial protein sources and BP lowering mechanisms are also addressed. In addition, recent studies on possible adverse effects of high protein diets are discussed. Most of the studies mentioned in this article increased protein intake from $15 \%$, which is considered normal, to $25-30 \%$ of energy intake. Thus a high protein diet of $2000 \mathrm{kcal}$ per day would increase protein intake from the normal value of $74 \mathrm{~g}$ per day to a maximum of $148 \mathrm{~g}$ per day.

Recently published short-term trials found a BP lowering effect of dietary proteins. The randomized clinical trial on the effects of proteins on blood pressure found that isoenergetically replacing $60 \mathrm{~g}$ per day maltodextrin for a protein mixture $130 \%$ egg protein, $30 \%$ milk protein, $20 \%$ soy protein, $20 \%$ pea protein) for 4 weeks lowered SBP ($4.9 \mathrm{mmHg}, P=0.005)$ and DBP $(-2.7 \mathrm{mmHg}, P=0.05)(7)^{\prime}$. Another randomized trial found that supplementation of $40 \mathrm{~g}$ per day soy protein or milk protein for 8 weeks compared with a complex carbohydrate lowered SBP $(-2.0 \mathrm{mmHg}, P=0.002$ and $-2.7 \mathrm{mmHg}, P=0.001$, respectively), with no differences between the protein sources (8) ${ }^{\boldsymbol{\prime}}$. In contrast, longer trials show less clear effects. Supplementation with $30 \mathrm{~g}$ per day of whey protein compared with maltodextrin did not lower BP in elderly women after either 1 or 2 years of 
supplementation (9) ${ }^{\boldsymbol{m}}$. In type 2 diabetic patients, 12 months (3 months caloric restriction and 9 months weight maintenance) of dietary advice for a high protein diet (30\% protein, $40 \%$ carbohydrate) versus high carbohydrate diet (15\% protein, $55 \%$ carbohydrate) reduced SBP more after 3 months $(-3.0 \mathrm{mmHg}, P=0.04)$ as well as after 12 months (-4.3 $\mathrm{mmHg}, P=0.05)$ in the high protein group. However these differences were no longer statistically significant after stringent corrections for multiple testing (10). Another study found no differences in BP after 6 and 18 weeks on a high protein diet (131g per day), a high carbohydrate diet, a high cereal fiber diet and a mixed diet with increased protein and fiber content (11). Reasons that long-term studies found no effects may be decreased dietary compliance (11), higher dropout rates (12), or weakening of the short-term hypotensive effects of increased protein intake in the long term. More detailed time course trials are needed to study changes in BP during high protein diets over time. Weight loss trials with high protein diets are also inconclusive. One large trial found no effects of high protein diets (13), whereas the other found significantly lower DBP (-3.7 $\mathrm{mmHg}, P=0.01$ ) (14).

Since the Omniheart trial in 2005 (15) the question rose whether the beneficial effects of high protein diets on BP are due to increased protein content or due to reduced carbohydrate content (6). The Omniheart trial, a large well-controlled intervention trial, suggested that lowering carbohydrate intake rather than increasing protein intake may lower BP, because only increasing protein intake at the expense of carbohydrates, but not at the expense of fat, reduced SBP (15). As all abovementioned studies compared dietary protein with carbohydrates, this question remains unanswered. Only one other small study (16) compared protein with fat intake and found, in contrast to the Omniheart trial, that increased protein intake also lowered BP compared with fat. Larger trials are necessary to confirm this. Therefore, the question whether the beneficial effects of high protein diets on BP are due to increased protein content or due to reduced carbohydrate content (6) has not been resolved yet.

\section{EFFECTS OF DIFFERENT PROTEIN SOURCES ON BLOOD PRESSURE}

Altorf-van der Kuil et al. (6) concluded, based on observational studies, that the small beneficial effect of dietary protein on BP was mainly attributable to plant protein (6). Additional findings in a Dutch cross-sectional sample confirmed that higher plant protein intake was associated with lower BP, whereas no clear associations were found between total protein or animal protein intake and BP (17). A cross-sectional study in Iran found that the ratio between animal and plant protein intake was not associated with BP (18). Also a prospective Dutch cohort study found no association of total protein, plant protein or animal protein with risk for hypertension. Only protein intake from grain was inversely 
associated with incident hypertension (19). A 2-year prospective cohort study suggested a beneficial effect of plant versus animal proteins on BP (20). Quartiles of methionine and alanine intake were directly associated with BP, whereas quartiles of threonine and histidine intake showed an inverse association. Plant proteins have a lower ratio of methionine and alanine to threonine and histidine compared to animal proteins (20)".

BP lowering effects of specific animal and plant protein sources have also been investigated in trials. A meta-analysis of randomized controlled trials found that soy protein lowers BP compared with carbohydrates (SBP $-4.5 \mathrm{mmHg}, P=0.002$, DBP -3.0 $\mathrm{mmHg}, P=0.004)$, but this BP reduction tended to be smaller and not significant when soy protein was compared with milk proteins (SBP $-2.0 \mathrm{mmHg}, P=0.18, D B P-1.3 \mathrm{mmHg}$, $P=0.13)(21)^{\prime}$. Soy foods are thought to be hypotensive due to their protein and flavonoid content. Lupin is a legume high in protein and fiber. Consumption of products containing lupin flour (16-20g protein, 11g fiber per 100g), compared with wheat flour (4-11g protein, 3-5g fiber per 100g), during 4 months of weight loss and 8 months of ad libitum weight maintenance reduced $24 \mathrm{~h}$ ambulatory BP (systolic BP $-1.3 \mathrm{mmHg}$, diastolic BP $-1.0 \mathrm{mmHg}$, both $P=0.02$ ) (22). Many (23-26), but not all (27) recent observational studies found beneficial effects of dairy or low-fat dairy intake on BP. Recent randomized trials are inconclusive. One trial found that SBP was lowered after 8 weeks of low-fat dairy consumption $(-2.9 \mathrm{mmHg}, P=0.03)(28)$, whereas another study found no effect on $B P$ after 6 months of increased low-fat dairy consumption $(0.9 \mathrm{mmHg}, P=0.51)$ (29). Dairy foods may lower BP because of their protein content, their micronutrient content and the formation of angiotensin converting enzyme (ACE) inhibiting bioactive peptides in the gastrointestinal tract $(25,30)$.

Differing amino acid compositions of animal and plant proteins may explain differences in their BP lowering effects. An overview of the effects of different amino acids on BP is provided in the review by Vasdev and Stuckless (5). Two additional reviews, on the BP lowering effects of taurine and arginine respectively, have been published recently. Taurine is an amino acid-like component of foods of animal origin, which has beneficial effects on BP and the vasculature (31). Arginine, present in animal and plant proteins, was found to have hypotensive effects according to a meta-analysis of 11 randomized placebo controlled trials (32).

Thus, although observational studies suggest that plant protein intake may be more beneficial for BP than animal protein, trials have, thus far not confirmed such general difference. Further randomized controlled trials are needed to investigate the hypotensive effect of specific proteins, peptides and amino acids. 


\section{BLOOD PRESSURE LOWERING MECHANISMS OF DIETARY PROTEINS}

Understanding of the mechanisms by which dietary proteins, peptides and amino acids modulate BP, also discussed by Vasdev and Stuckless (5), can provide further insight into which sources of dietary proteins may lower BP. BP is a product of cardiac output and total peripheral resistance (TPR). Thus, BP lowering mechanisms act via these parameters. One BP lowering mechanism may be ACE inhibition by bioactive peptides. ACE inhibition results in reduced angiotensin II formation, reduced vasoconstriction and lower TPR and BP (33). Studies with milk-derived ACE inhibiting peptides are inconsistent $(34,35)$. A recent review (33) and meta-analysis (36) both pointed out that even though earlier research has shown promising results, many recent studies could not demonstrate a BP lowering effect or an ACE inhibiting effect of lactotripeptides. An acute study found that active milk (containing bioactive tripeptides and plant sterols) lowered BP postprandially for $8 \mathrm{~h}$ compared with control milk. However, the renin-angiotensin system was not affected systemically. Higher urinary NO values and cyclic guanosine monophosphate excretion suggested that improved endothelial function may have reduced BP (37). Bioactive peptides from other sources apart from milk are being developed and tested for their effects on BP and ACE inhibition $(38,39)$. However, their effects need to be confirmed in large randomized trials with humans. Although systemic ACE inhibition is usually not found, this does not exclude a role of local ACE inhibition (for example, in the gastrointestinal tract) in the BP lowering effect of bioactive peptides. Taken together, recent trials and reviews do not support the idea that bioactive peptides inhibit ACE systemically. In addition, in the light of recent studies a potential BP lowering effect of bioactive peptides also remains controversial.

Another BP lowering mechanism is arginine-induced vasodilation with arginine serving as a substrate for NO production. L-arginine may only augment NO production when levels of asymmetric dimethylarginine (ADMA), an endogenous NO synthase inhibitor, are elevated. Physiological concentrations of plasma arginine may be sufficient for saturating the NO synthase pathway when ADMA levels are normal (40). Tryptophan may also reduce BP by augmenting NO production. Tryptophan is a precursor of serotonin, which may stimulate NO-synthase via yet unknown mechanisms (41). Tryptophan may also modulate BP by reducing epinephrine and norepinephrine release (5).

Despite these and other (5) BP lowering effects associated with dietary protein intake, acute BP responses to protein consumption compared with other macronutrients are not always in line with the chronic hypotensive effect of dietary protein. For instance, isoenergetic breakfasts supplemented with $45 \mathrm{~g}$ casein, whey or glucose did not differ in 6h postprandial response of BP, augmentation index and inflammatory markers (42)" Although $60 \mathrm{~g}$ per day of whey protein isolate during 20 weeks ( 8 weeks weight loss, 12 
weeks ad libitum diet) reduced SBP compared with the control (carbohydrate) diet (43). Another acute study found that postprandial TPR and mean arterial pressure (MAP) were decreased in elderly patients after consumption of meals composed of high carbohydrate or high fat foods, but not after an isoenergetic meal composed of high protein foods. The absence of a response after the protein meal was ascribed to differences in postprandial gut hormones. However, these were not measured (44)" ${ }^{\boldsymbol{\prime}}$. Interactions of dietary proteins with the gastrointestinal tract and release of vasoactive hormones, such as glucagon-like peptide-1 (GLP-1), glucose-dependent insulinotropic polypeptide (GIP) and insulin, from the gastrointestinal tract have been reviewed recently (45)".

In summary, dietary proteins may lower BP via several mechanisms. However, postprandial changes in BP after protein consumption are not necessarily in line with longterm effects. Divergent postprandial BP responses may be explained by differences in the degree of vasodilation, mediated by NO, ACE inhibition or gastrointestinal hormones, and differences in the compensatory response of cardiac output, although this mechanism has hardly been studied so far. Further research is necessary to explore mechanisms involved in postprandial responses to dietary protein and to find out whether and how differences in acute responses are linked to differences in long-term effects of increased protein intake.

\section{ADVERSE EFFECTS OF INCREASED PROTEIN INTAKE}

A concern of high protein intake is that it may be harmful for renal function, especially in vulnerable groups. Therefore, patients with chronic renal failure are advised to consume 0.6-0.75 g protein/kg body weight per day. This amount of protein intake should be enough to maintain a healthy nutritional status, although limiting possible adverse effects of high protein intake (46). It has been suggested that mainly animal protein may be harmful for kidney function (47). One of the reasons why increased protein intake may negatively affect renal function and BP is the increased acid load associated with high protein intake. This could introduce a vicious cycle because acid load may lead to kidney damage and hypertension, which are interrelated (48). Indeed, increased protein intake was directly associated with net acid excretion in a cross-sectional sample of renal transplant recipients, but no associations were observed between net acid excretion and acidosis related complications like hypertension and insulin resistance in this susceptible group (49). Furthermore, no association between dietary acid load and risk of hypertension was found in a Dutch prospective cohort (50).

Three months on a high protein weight loss diet was shown to induce hyperfiltration (51) ". Hyperfiltration is hypothesized to be a precursor of intra-glomerular hypertension leading to albuminuria. Glomerular filtration rate (GFR) then falls progressively, which may 
lead, in the long run, to end-stage renal failure (52). However no adverse effects were found on GFR, albuminuria or fluid and electrolyte balance after 2 years on the high protein weight loss diet in healthy obese subjects $(51)^{\boldsymbol{m}}$. This could be because increased GFR with high protein intake is associated with increased renal size (53).

It has been suggested that colonic health may be adversely affected by high protein diets characterized by high meat intake. Four weeks on high protein (138g per day) weight loss diets increased the amount of fecal carcinogenic N-nitroso compounds (NOCs)(54)" Further analyses revealed that the amount of fecal NOC was directly associated with meat intake and nitrate intake (from vegetables) and inversely associated with energy intake, vitamin C intake and nonstarch polysaccharides (55). This suggests that both increased meat protein intake and low carbohydrate intake may be harmful for colonic health. Other studies also suggested that a very low carbohydrate content in high protein diets may increase the risk for all-cause mortality (56), cardiovascular disease (57) and type 2 diabetes (58).

In summary, concerns still exist for the safety of high protein diets, especially in vulnerable subgroups, due to increased acid loading and hyperfiltration. However, recent studies found that increased acid load and hyperfiltration induced by high protein diets may not be as harmful as initially thought. In addition other possible adverse effects from high protein diets, like decreased colonic health, may arise from the low carbohydrate intake characterizing these diets rather than the high protein intake per se.

\section{CONCLUSION}

Randomized trials, especially long-term trials, remain inconclusive on the BP lowering effects of dietary proteins. This may result from different protein sources affecting differing hypotensive mechanisms. Available evidence shows no clear differences in the hypotensive effects of plant protein intake versus animal protein intake. Acute studies may give insight into their hypotensive mechanisms but are not easily translated to longterm effects. Evidence suggests that it may be safe for kidney function to increase protein intake. The question whether it is increased protein intake or decreased carbohydrate intake that affects BP has not yet been answered.

\section{ACKNOWLEDGEMENTS}

TI Food and Nutrition is a public private partnership of science, industry and government conducting strategic research in food and nutrition (www.tifn.nl).

Conflicts of interest

There are no conflicts of interest. 


\title{
REFERENCES AND RECOMMENDED READING
}

Papers of particular interest, published within the annual period of review, have been highlighted as:

\author{
- of special interest \\ - of outstanding interest
}

1. Sousa GT, Lira FS, Rosa JC, de Oliveira EP, Oyama LM, Santos RV, et al. Dietary whey protein lessens several risk factors for metabolic diseases: a review. Lipids Health Dis. 2012;11:67.

2. Santesso N, Akl EA, Bianchi M, Mente A, Mustafa R, Heels-Ansdell D, et al. Effects of higher- versus lower-protein diets on health outcomes: a systematic review and meta-analysis. Eur J Clin Nutr. 2012;66(7):780-8.

3. Johnstone AM. Safety and efficacy of high-protein diets for weight loss. Proc Nutr Soc. 2012;71(2):33949.

4. Cam A, de Mejia EG. Role of dietary proteins and peptides in cardiovascular disease. Mol Nutr Food Res. 2012;56(1):53-66.

5. Vasdev S, Stuckless J. Antihypertensive effects of dietary protein and its mechanism. Int J Angiol. 2010;19(1):e7-e20.

6. Altorf-van der Kuil W, Engberink MF, Brink EJ, van Baak MA, Bakker SJ, Navis G, et al. Dietary protein and blood pressure: a systematic review. PLoS One. 2010;5(8):e12102.

7. Teunissen-Beekman KF, Dopheide J, Geleijnse JM, Bakker SJ, Brink EJ, de Leeuw PW, et al. Protein supplementation lowers blood pressure in overweight adults: effect of dietary proteins on blood pressure (PROPRES), a randomized trial. Am J Clin Nutr. 2012;95(4):966-71.

Randomized trial showing that a protein mixture lowers BP in 4 weeks compared with carbohydrate.

8. He J, Wofford MR, Reynolds K, Chen J, Chen CS, Myers L, et al. Effect of dietary protein supplementation on blood pressure: a randomized, controlled trial. Circulation. 2011;124(5):589-95.

Randomized trial showing that soy and milk protein isolate equally lower BP compared with carbohydrate in 8 weeks.

9. Hodgson JM, Zhu K, Lewis JR, Kerr D, Meng X, Solah V, et al. Long-term effects of a protein-enriched diet on blood pressure in older women. Br J Nutr. 2012;107(11):1664-72.

Randomized trial showing no effects on BP after 1 and 2 year of whey protein supplementation.

10. Larsen RN, Mann NJ, Maclean E, Shaw JE. The effect of high-protein, low-carbohydrate diets in the treatment of type 2 diabetes: a 12 month randomised controlled trial. Diabetologia. 2011;54(4):731-40.

11. Weickert MO, Roden M, Isken F, Hoffmann D, Nowotny P, Osterhoff M, et al. Effects of supplemented isoenergetic diets differing in cereal fiber and protein content on insulin sensitivity in overweight humans. Am J Clin Nutr. 2011;94(2):459-71.

12. Crichton GE, Howe PR, Buckley JD, Coates AM, Murphy KJ, Bryan J. Long-term dietary intervention trials: critical issues and challenges. Trials. 2012;13(1):111.

13. Campbell DD, Meckling KA. Effect of the protein:carbohydrate ratio in hypoenergetic diets on metabolic syndrome risk factors in exercising overweight and obese women. Br J Nutr. 2012;108(9):1658-71.

14. Te Morenga LA, Levers MT, Williams SM, Brown RC, Mann J. Comparison of high protein and high fiber weight-loss diets in women with risk factors for the metabolic syndrome: a randomized trial. Nutr J. 2011;10:40.

15. Appel LJ, Sacks FM, Carey VJ, Obarzanek E, Swain JF, Miller ER, 3rd, et al. Effects of protein, monounsaturated fat, and carbohydrate intake on blood pressure and serum lipids: results of the OmniHeart randomized trial. Jama. 2005;294(19):2455-64.

16. Papakonstantinou E, Triantafillidou D, Panagiotakos DB, Koutsovasilis A, Saliaris M, Manolis A, et al. A high-protein low-fat diet is more effective in improving blood pressure and triglycerides in calorierestricted obese individuals with newly diagnosed type 2 diabetes. Eur J Clin Nutr. 2010;64(6):595-602.

17. Altorf-van der Kuil W, Engberink MF, Vedder MM, Boer JM, Verschuren WM, Geleijnse JM. Sources of dietary protein in relation to blood pressure in a general Dutch population. PLoS One. 2012;7(2):e30582. 
18. Mirmiran P, Hajifaraji M, Bahadoran Z, Sarvghadi F, Azizi F. Dietary protein intake is associated with favorable cardiometabolic risk factors in adults: Tehran Lipid and Glucose Study. Nutr Res. 2012;32(3):169-76.

19. Altorf-van der Kuil W, Engberink MF, Geleijnse JM, Boer JM, Verschuren WM. Sources of dietary protein and risk of hypertension in a general Dutch population. Br J Nutr. 2012;108(10):1897-903.

20. Tuttle KR, Milton JE, Packard DP, Shuler LA, Short RA. Dietary amino acids and blood pressure: a cohort study of patients with cardiovascular disease. Am J Kidney Dis. 2012;59(6):803-9.

Two-year prospective cohort study adressing associations between intake of amino acids and BP.

21. Dong JY, Tong X, Wu ZW, Xun PC, He K, Qin LQ. Effect of soya protein on blood pressure: a meta-analysis of randomised controlled trials. Br J Nutr. 2011;106(3):317-26.

Meta-analysis showing that soy protein intake reduces BP compared with control diets.

22. Belski R, Mori TA, Puddey IB, Sipsas S, Woodman RJ, Ackland TR, et al. Effects of lupin-enriched foods on body composition and cardiovascular disease risk factors: a 12-month randomized controlled weight loss trial. Int J Obes (Lond). 2011;35(6):810-9.

23. Crichton GE, Elias MF, Dore GA, Abhayaratna WP, Robbins MA. Relations between dairy food intake and arterial stiffness: pulse wave velocity and pulse pressure. Hypertension. 2012;59(5):1044-51.

24. Rangan AM, Flood VL, Denyer G, Ayer JG, Webb KL, Marks GB, et al. The effect of dairy consumption on blood pressure in mid-childhood: CAPS cohort study. Eur J Clin Nutr. 2012;66(6):652-7.

25. Ralston RA, Lee JH, Truby H, Palermo CE, Walker KZ. A systematic review and meta-analysis of elevated blood pressure and consumption of dairy foods. J Hum Hypertens. 2012;26(1):3-13.

26. Vernay M, Aidara M, Salanave B, Deschamps V, Malon A, Oleko A, et al. Diet and blood pressure in 1874-year-old adults: the French Nutrition and Health Survey (ENNS, 2006-2007). J Hypertens. 2012;30(10):1920-7.

27. Heraclides A, Mishra GD, Hardy RJ, Geleijnse JM, Black S, Prynne CJ, et al. Dairy intake, blood pressure and incident hypertension in a general British population: the 1946 birth cohort. Eur J Nutr. 2012;51(5):583-91.

28. van Meijl LE, Mensink RP. Low-fat dairy consumption reduces systolic blood pressure, but does not improve other metabolic risk parameters in overweight and obese subjects. Nutr Metab Cardiovasc Dis. 2011;21(5):355-61.

29. Crichton GE, Howe PR, Buckley JD, Coates AM, Murphy KJ. Dairy consumption and cardiometabolic health: outcomes of a 12-month crossover trial. Nutr Metab (Lond). 2012;9(1):19.

30. McGrane MM, Essery E, Obbagy J, Lyon J, Macneil P, Spahn J, et al. Dairy Consumption, Blood Pressure, and Risk of Hypertension: An Evidence-Based Review of Recent Literature. Curr Cardiovasc Risk Rep. 2011;5(4):287-98.

31. Abebe W, Mozaffari MS. Role of taurine in the vasculature: an overview of experimental and human studies. Am J Cardiovasc Dis. 2011;1(3):293-311.

32. Dong JY, Qin LQ, Zhang Z, Zhao Y, Wang J, Arigoni F, et al. Effect of oral L-arginine supplementation on blood pressure: a meta-analysis of randomized, double-blind, placebo-controlled trials. Am Heart $\mathrm{J}$. 2011;162(6):959-65.

33. Ricci-Cabello I, Herrera MO, Artacho R. Possible role of milk-derived bioactive peptides in the treatment and prevention of metabolic syndrome. Nutr Rev. 2012;70(4):241-55.

34. Cicero AF, Rosticci M, Ferroni A, Bacchelli S, Veronesi M, Strocchi E, et al. Predictors of the Short-Term Effect of Isoleucine-Proline-Proline/Valine-Proline-Proline Lactotripeptides from Casein on Office and Ambulatory Blood Pressure in Subjects with Pharmacologically Untreated High-Normal Blood Pressure or First-Degree Hypertension. Clin Exp Hypertens. 2012;34(8):601-5.

35. Jauhiainen T, Niittynen L, Oresic M, Jarvenpaa S, Hiltunen TP, Ronnback M, et al. Effects of long-term intake of lactotripeptides on cardiovascular risk factors in hypertensive subjects. Eur J Clin Nutr. 2012;66(7):843-9.

36. Usinger L, Reimer C, Ibsen H. Fermented milk for hypertension. Cochrane Database Syst Rev. 2012;4:CD008118.

37. Turpeinen AM, Ehlers PI, Kivimaki AS, Jarvenpaa S, Filler I, Wiegert E, et al. Ile-Pro-Pro and Val-Pro-Pro tripeptide-containing milk product has acute blood pressure lowering effects in mildly hypertensive subjects. Clin Exp Hypertens. 2011;33(6):388-96.

38. Li H, Prairie N, Udenigwe CC, Adebiyi AP, Tappia PS, Aukema HM, et al. Blood pressure lowering effect of a pea protein hydrolysate in hypertensive rats and humans. J Agric Food Chem. 2011;59(18):9854-60. 
39. Udenigwe CC, Adebiyi AP, Doyen A, Li H, Bazinet L, Aluko RE. Low molecular weight flaxseed proteinderived arginine-containing peptides reduced blood pressure of spontaneously hypertensive rats faster than amino acid form of arginine and native flaxseed protein. Food Chemistry. 2012;132:468-75.

40. Alvares TS, Conte-Junior CA, Silva JT, Flosi Paschoalin VM. Acute L-Arginine supplementation does not increase nitric oxide production in healthy subjects. Nutrition \& metabolism. 2012;9(1):54.

41. Watts SW, Morrison SF, Davis RP, Barman SM. Serotonin and blood pressure regulation. Pharmacol Rev. 2012;64(2):359-88.

42. Pal S, Ellis V. Acute effects of whey protein isolate on blood pressure, vascular function and inflammatory markers in overweight postmenopausal women. Br J Nutr. 2011;105(10):1512-9.

Acute study showing no differences in BP, vascular function and inflammatory markers in $6 \mathrm{~h}$ after breakfasts supplemented with whey protein, casein protein or carbohydrate.

43. Aldrich ND, Reicks MM, Sibley SD, Redmon JB, Thomas W, Raatz SK. Varying protein source and quantity do not significantly improve weight loss, fat loss, or satiety in reduced energy diets among midlife adults. Nutr Res. 2011;31(2):104-12.

44. Ferreira-Filho SR, de Castro Rodrigues Ferreira AC, de Oliveira PC. Systemic hemodynamic changes in young and elderly normotensive individuals after ingestion of meals with high lipid, protein, and carbohydrate contents. Blood Press Monit. 2012;17(3):110-5.

Acute study showing no changes in BP $1 \mathrm{~h}$ after protein consumption in elderly and young patients, whereas carbohydrate and fat ingestion reduced BP.

45. Jahan-Mihan A, Luhovyy BL, El Khoury D, Anderson GH. Dietary proteins as determinants of metabolic and physiologic functions of the gastrointestinal tract. Nutrients. 2011;3(5):574-603.

Review addressing differential interactions of protein sources with the gastro-intestinal tract.

46. K/DOQI. Clinical practice guidelines for nutrition in chronic renal failure. K/DOQI, National Kidney Foundation. Am J Kidney Dis. 2000;35(6 Suppl 2):S1-140.

47. Odermatt A. The Western-style diet: a major risk factor for impaired kidney function and chronic kidney disease. Am J Physiol Renal Physiol. 2011;301(5):F919-31.

48. van den Berg E, Hospers FA, Navis G, Engberink MF, Brink EJ, Geleijnse JM, et al. Dietary acid load and rapid progression to end-stage renal disease of diabetic nephropathy in Westernized South Asian people. J Nephrol. 2011;24(1):11-7.

49. van den Berg E, Engberink MF, Brink EJ, van Baak MA, Joosten MM, Gans RO, et al. Dietary Acid Load and Metabolic Acidosis in Renal Transplant Recipients. Clin J Am Soc Nephrol. 2012;7(11):1811-8.

50. Engberink MF, Bakker SJ, Brink EJ, van Baak MA, van Rooij FJ, Hofman A, et al. Dietary acid load and risk of hypertension: the Rotterdam Study. Am J Clin Nutr. 2012;95(6):1438-44.

51. Friedman AN, Ogden LG, Foster GD, Klein S, Stein R, Miller B, et al. Comparative effects of lowcarbohydrate high-protein versus low-fat diets on the kidney. Clin J Am Soc Nephrol. 2012;7(7):1103-11.

Randomized trial showing no adverse outcomes on kidney function after 2 years consumption of a low carbohydrate high protein weight loss diet in obese individuals.

52. Palatini P. Glomerular hyperfiltration: a marker of early renal damage in pre-diabetes and prehypertension. Nephrol Dial Transplant. 2012;27(5):1708-14.

53. Skov AR, Toubro S, Bulow J, Krabbe K, Parving HH, Astrup A. Changes in renal function during weight loss induced by high vs low-protein low-fat diets in overweight subjects. Int J Obes Relat Metab Disord. 1999;23(11):1170-7.

54. Russell WR, Gratz SW, Duncan SH, Holtrop G, Ince J, Scobbie L, et al. High-protein, reducedcarbohydrate weight-loss diets promote metabolite profiles likely to be detrimental to colonic health. Am J Clin Nutr. 2011;93(5):1062-72.

Randomized trial addressing adverse effects of reduced carbohydrate content in high protein weight loss diets on colonic health.

55. Holtrop G, Johnstone AM, Fyfe C, Gratz SW. Diet composition is associated with endogenous formation of N-nitroso compounds in obese men. J Nutr. 2012;142(9):1652-8.

56. Nilsson LM, Winkvist A, Eliasson M, Jansson JH, Hallmans G, Johansson I, et al. Low-carbohydrate, highprotein score and mortality in a northern Swedish population-based cohort. Eur J Clin Nutr. 2012;66(6):694-700.

57. Lagiou P, Sandin S, Lof M, Trichopoulos D, Adami HO, Weiderpass E. Low carbohydrate-high protein diet and incidence of cardiovascular diseases in Swedish women: prospective cohort study. BMJ. 2012;344:e4026. 
58. Simila ME, Kontto JP, Valsta LM, Mannisto S, Albanes D, Virtamo J. Carbohydrate substitution for fat or protein and risk of type 2 diabetes in male smokers. Eur J Clin Nutr. 2012;66(6):716-21 


\section{Chapter 3}

Protein supplementation lowers blood pressure in overweight adults: effect of dietary proteins on blood pressure (PROPRES), a randomized

trial

Am J Clin Nutr. 2012 Feb 22;95(4):966-71

Karianna F.M. Teunissen-Beekman Janneke Dopheide Johanna M. Geleijnse Stephan J.L. Bakker Elizabeth J. Brink Peter W. de Leeuw Marleen A. van Baak 


\section{ABSTRACT}

\section{Background}

Dietary protein intake may help to manage blood pressure (BP) and prevent complications associated with elevated BP.

\section{Objective}

The objective of this study was to determine whether $4 \mathrm{wk}$ of increased protein intake ( 25\% compared with $\sim 15 \%$ of energy intake that isoenergetically replaces carbohydrate intake) lowers office and daytime BP compared with increased carbohydrate intake.

\section{Design}

A randomized, double-blind, parallel study compared consumption of $3 \times 20 \mathrm{~g}$ protein/d ( $20 \%$ pea, $20 \%$ soy, $30 \%$ egg, and 30\% milk-protein isolate) with $3 \times 20$ g maltodextrin/d. Protein or maltodextrin were isoenergetically substituted for a sugar-sweetened drink. Primary outcomes were office and daytime BP. A total of 99 men and women (age range 20-70 y; BMI (in $\mathrm{kg} / \mathrm{m}^{2}$ ): 25 - 35) with untreated elevated BP ( $B P \geq 130 / 85$ and $<160 / 100 \mathrm{mmHg}$ ) were randomly assigned. Ninety-four completers (51 subjects in the maltodextrin group, 43 subjects in the protein group) were included in the analyses.

Results

Office systolic blood pressure (SBP) and diastolic blood pressure (DBP) were $4.9 \pm 1.7$ $\mathrm{mmHg}(P=0.005)$ and $2.7 \pm 1.3 \mathrm{mmHg}(P=0.05)$ lower in the protein group. Daytime SBP was $4.6 \pm 1.7 \mathrm{mmHg}$ lower in the protein group $(P=0.006)$, whereas daytime DBP did not differ between groups $(P=0.37)$. Urinary sodium excretion was higher in the maltodextrin group $(P=0.004)$.

\section{Conclusions}

Increased protein intake, at the expense of maltodextrin, lowers BP in overweight adults with upper-range prehypertension and grade 1 hypertension. This trial was registered at www.trialregister.nl as NTR 1362. 


\section{INTRODUCTION}

Observational studies indicated that protein intake $(1,2)$, particularly plant protein intake $(3,4)$, may be inversely related to BP. However, randomized controlled trials on the BPlowering effects of dietary protein have produced inconsistent results (5-9). In a systematic review, Altorf-van der Kuil et al. (10) concluded that increased protein intake may have beneficial effects on BP.

The question of whether it is really the protein fraction of the diet that is responsible for the BP-lowering effect of protein-enriched diets remained because most studies increased the intake of protein-rich foods (6-9) and reduced the intake of carbohydrate-rich foods (6-8) to attain the difference in macronutrient composition. This may have introduced changes in other nutrients or nonnutrients that influenced the BP response. To eliminate these factors as much as possible, we performed the effect of dietary proteins on blood pressure (PROPRES) study, in which an isocaloric difference in protein and carbohydrate intakes was created by providing supplements on top of a standard diet. The protein supplement consisted of a mixture of 4 proteins from different sources, which represented the balance between sources of animal and plant protein in the habitual Dutch diet. We hypothesized that the protein-supplemented diet would lower office and daytime BP over a 4-wk period compared with a maltodextrin-supplemented diet in overweight and obese individuals with untreated upper-range prehypertension or grade 1 hypertension.

\section{SUBJECTS AND METHODS}

PROPRES was a 2-arm, double-blind, randomized, parallel trial that compared the BP effects of a diet high in protein to those of a diet high in carbohydrates. The study was conducted in Maastricht (Netherlands) from September 2008 until December 2009. The study was approved by the Medical-Ethical Committee of Maastricht University Medical Center and Maastricht University in Maastricht. All participants gave written informed consent.

\section{Participants}

Participants were overweight (BMI (in kg/ $\mathrm{m}^{2}$ ): 25-35) men and women, aged 20-70 y, with untreated upper-range prehypertension or hypertension grade 1 (SBP of 130-159 mm Hg and/or DBP of $85-99 \mathrm{mmHg}$ ) at the time of random assignment. Participants were nonsmokers with a fasting plasma glucose concentration $<7 \mathrm{mmol} / \mathrm{L}$ and an estimated glomerular filtration rate (on the basis of plasma creatinine, age, and sex) of $\geq 60 \mathrm{~mL} \cdot \mathrm{min}^{-}$ ${ }^{1} \cdot\left(1.73 \mathrm{~m}^{2}\right)^{-1}$ at screening. Furthermore, participants had stable weight in the 3 mo before the study and did not use vitamin or mineral supplements or take medication that could 


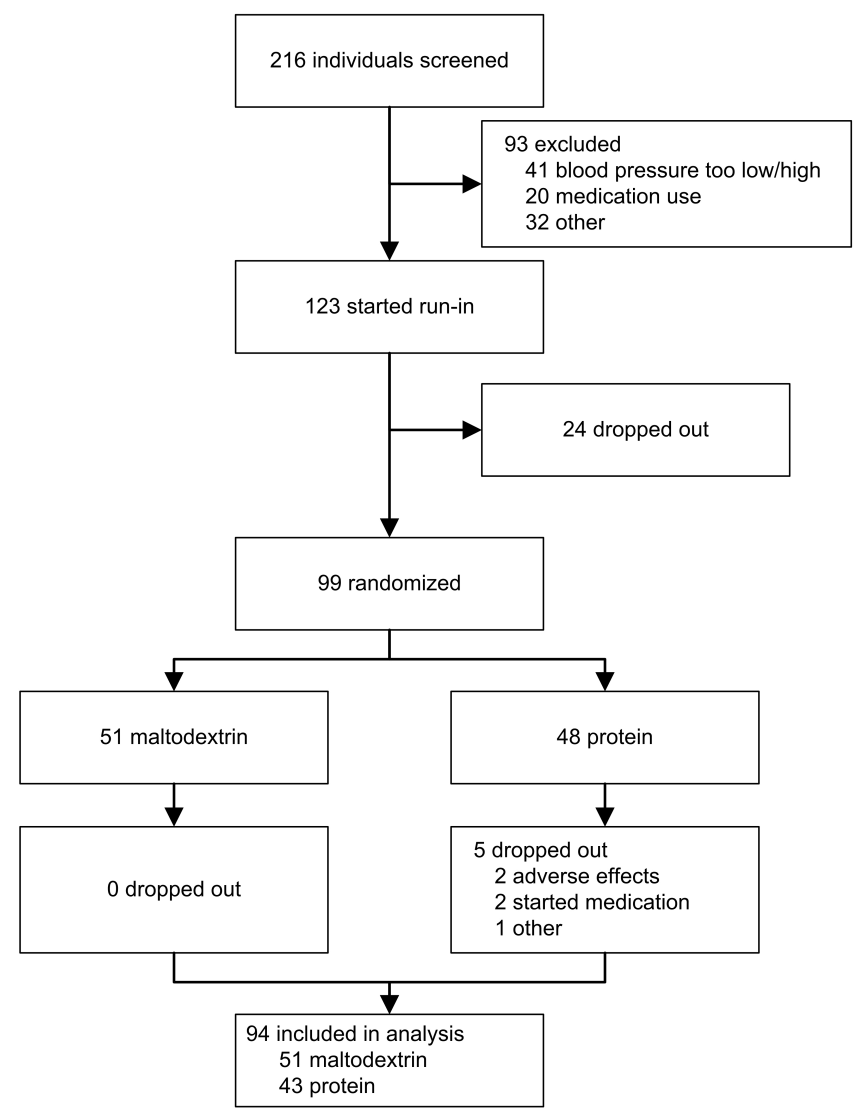

Figure 1. Flow diagram of participants in the effect of dietary proteins on blood pressure (PROPRES) study.

influence BP. The absence of proteinuria was tested by using a Multistix urine dipstick (Siemens Healthcare Diagnostics BV).

\section{Study protocol}

Participant eligibility for the study was established during a screening visit. After inclusion, participants started with a 2-wk run-in period followed by the 4-wk intervention. Each week, participants visited a dietitian who weighed them, measured their BP, advised them on a weight-maintaining diet with a standard composition, and provided them with supplement sachets during the intervention period.

If the BP of participants met the inclusion criteria at the end of the run-in period, participants were stratified for SBP (130-139 and $\geq 140 \mathrm{mmHg})$, sex, and age $(<50 \mathrm{y}$ and $\geq 50 y$ ), and randomly assigned to the protein or control group (maltodextrin) with a computer program (MINIM; http://www-users.york.ac.uk/ mb55/ guide/minim.htm). Supplement sachets were marked A or B to blind participants and the research staff to the

\section{Chapter 3}


Table 1. Supplement composition per serving and intake from supplements per day ${ }^{1}$

\begin{tabular}{|c|c|c|c|c|c|c|}
\hline & \multicolumn{3}{|c|}{ Protein } & \multicolumn{3}{|c|}{ Maltodextrin } \\
\hline & $\begin{array}{c}\text { Per } \\
\text { serving }\end{array}$ & Per day & $\mathrm{mmol} / \mathrm{day}$ & $\begin{array}{c}\text { Per } \\
\text { serving }\end{array}$ & Per day & $\mathrm{mmol} / \mathrm{day}$ \\
\hline Weight, g & 24.9 & 74.7 & & 24.1 & 72.3 & \\
\hline Energy, kcal & 89 & 267 & & 84 & 252 & \\
\hline Protein, $\mathrm{g}$ & 20.3 & 60.9 & & 0.0 & 0 & \\
\hline Carbohydrate, g & 0.3 & 0.9 & & 20.1 & 60.3 & \\
\hline Fat, $g$ & 0.7 & 2.1 & & 0.0 & 0 & \\
\hline Fibre, $g$ & 0.2 & 0.6 & & 0.0 & 0 & \\
\hline \multicolumn{7}{|l|}{ Minerals } \\
\hline Sodium, mg & 196 & 587 & 26 & 241 & 724 & 32 \\
\hline Potassium, mg & 103 & 310 & 8 & 139 & 416 & 11 \\
\hline Calcium, mg & 148 & 445 & 11 & 188 & 564 & 14 \\
\hline Phosphate, mg & 191 & 574 & 6 & 226 & 679 & 7 \\
\hline Magnesium, mg & 16 & 49 & 2 & 22 & 65 & 3 \\
\hline
\end{tabular}

${ }^{1}$ Supplements were dissolved in $200 \mathrm{~mL}$ water and consumed with each meal (3 times per day). During the run-in period, participants consumed $200 \mathrm{ml}$ of soft drink or lemonade with each meal ( 20 gram sucrose)

intervention. Supplements were flavored with orange or vanilla flavor to mask the difference in sweetness between test substances. Participants were instructed not to communicate about the taste and texture of supplements with the research staff. At the end of the run-in period and 4-wk intervention, participants collected 24-h urine and measured their ambulatory BP during waking hours (0930-2130) on the same day.

\section{Diet}

A dietitian instructed participants to consume a diet that was composed of $15 \%$ of energy from protein, $30 \%$ of energy from fat, and $55 \%$ of energy from carbohydrates and to be moderate with salt intakes. During the 2 -wk run-in period, participants were instructed to drink a noncaffeine-containing sugar-sweetened drink ( $20 \mathrm{~g}$ of sucrose) with each meal. Participants were not allowed to consume $>2$ alcoholic consumptions/d and $>4$ caffeinecontaining consumptions/d.

During the 4-wk intervention period, participants replaced the sugar-sweetened drinks with each meal with $20 \mathrm{~g}$ maltodextrin or protein (Agglomix) dissolved in $200 \mathrm{~mL} \mathrm{H}_{2} \mathrm{O}$. Thus, $3 \times 20$ g sucrose was replaced by $3 \times 20$ g maltodextrin in the control group or $3 \times 20$ g protein in the protein group. The protein supplement consisted of $20 \%$ pea, $20 \%$ soy, $30 \%$ egg white and $30 \%$ milk-protein isolate. The mixture reflected the ratio between plant and animal proteins (40:60) in the average Dutch diet (11). Protein supplementation increased the protein intake to $25 \%$ of energy and decreased the carbohydrate intake to $\sim 45 \%$ of energy. Maltodextrin, which is a glucose polymer, is representative of starch-like foods. Supplements were isocaloric and matched for sodium, potassium, phosphate, magnesium, and calcium contents (table 1 ). 


\section{Measurements}

Primary study outcomes were between-group differences in office and daytime ambulatory BP after the 4-wk intervention. Office BP was measured during the weekly visits. Participants were $\geq 2 \mathrm{~h}$ postprandial at the start of measurements. After $10 \mathrm{~min}$ of rest, 3 BP measurements were taken in a sitting position (OMRON 6 comfort; Omron Healthcare Europe BV). The mean of the last 2 measurements was recorded for analysis. The run-in BP was calculated as the average BP measured at the end of the first and second week of the run-in period. The intervention BP was the BP measured at the end of week 4.

Ambulatory BP and HR were measured hourly between 0930 and $2130 \mathrm{~h}$ at the end of the run-in period and 4-wk intervention. Measurements were done with a validated (12) ambulatory BP monitor (Spacelabs 90207; Spacelabs Healthcare Ltd). The appropriate cuff size was chosen according to arm circumference, and subjects were instructed to hold their arm still during the BP measurement. The LCD display of the BP monitor was inactivated. Participants were instructed to perform their normal daily activities during the measurement day. Prolonged intense physical activity was to be avoided. The BP monitor was set to remove measurements with SBP $<70 \mathrm{mmHg}$ or $>260 \mathrm{mmHg}$, DBP $<40 \mathrm{mmHg}$ or $>150 \mathrm{mmHg}$ or pulse pressure $<20 \mathrm{mmHg}$ or $>150 \mathrm{mmHg}$.

A 24-h urine collection was performed at the end of the run-in and after 4 wk supplementation. An unprocessed urine sample was used for analysis of 24-h urinary sodium, potassium, creatinine, magnesium, albumin, sulfate and phosphate. Urine was acidified to $\mathrm{pH}=2$ for analysis of urinary calcium. Unprocessed and acidified urine samples were stored at $-80^{\circ} \mathrm{C}$ until analysis.

\section{Statistical analysis}

All analyses were performed with SPSS software (version 19.0; IBM). Values are expressed as means \pm SEs. Baseline and run-in characteristics were tested with an independent samples $t$ test for between-group differences unless stated otherwise. Weight changes during the intervention were analyzed by repeated-measures ANCOVA with run-in body weight as a covariate. Between-group differences in BP and urinary excretions after 4 wk supplementation were tested with a univariate ANCOVA with the run-in value as the covariate (analysis of completers) or with mixed-model analyses including all participants who were randomly assigned. In the mixed-model, run-in BP and BP after 4 wk were analyzed as repeated measures, and an interaction between group and time was tested. Available data from all participants who were randomly assigned were considered in the model, which, thus, included run-in BP from dropouts. The model assumed that BP in dropouts would follow the same course as in completers. 
Differences in albumin excretion between groups after the run-in period and after 4 wk supplementation were tested by using Mann-Whitney $U$ tests. Because urine collections are prone to collection errors, changes in urinary excretions were also analyzed after exclusion of subjects with $>20 \%$ difference in 24 -h urinary creatinine excretion between the 24-h urine collected after the run-in period and after 4 wk (13). Between-group difference in office and daytime BP was also analyzed with changes in urinary sodium excretion over $4 \mathrm{wk}$ as an additional covariate. Furthermore, the effect of hypertension status was explored by adding the interaction between hypertension status and supplementation group as a covariate to the initial model. Hypertension status was 1 for upper-range prehypertension and 2 for hypertension. For SBP, participants with SBP $\geq 140$ $\mathrm{mmHg}$ were considered hypertensive and for DBP, participants with DBP $\geq 90 \mathrm{mmHg}$ were considered hypertensive.

Between-group differences in run-in daytime BP were tested with a linear mixed-model analysis. Differences between groups in daytime (0930- 2230) BP and HR after 4 wk were tested with a linear mixed-model analysis, with correction for all run-in daytime BP or HR measurements at the end of the run-in period.

With a sample size of 94 subjects and SD of $7.7 \mathrm{mmHg}$ in the maltodextrin group and 9 $\mathrm{mmHg}$ in the protein group, the power to show a significant difference $(\propto=0.05)$ of 5 $\mathrm{mmHg}$ in office SBP between groups was 0.81 .

\section{RESULTS}

\section{Participants}

A total of 123 participants started with the run-in period, of whom 99 subjects were randomly assigned (figure 1). Five participants in the protein group dropped out during the intervention. Two participants stopped because of immediate adverse effects after consumption of the supplement (one subject experienced nausea, and one subject experienced a lightly swollen face, abdomen, and thighs. Two participants were excluded after randomization because they started with antihypertensive medication, and one subject stopped for personal reasons that were not related to the intervention. A total of 94 participants completed the trial (51 subjects in the maltodextrin group and 43 subjects in the protein group) (figure 1).

\section{Baseline characteristics}

The protein and maltodextrin groups were comparable at screening for BMI, age, SBP, DBP, and plasma creatinine. Fasting blood glucose was higher in the maltodextrin group $(P$ $=0.05$ ). Run-in office SBP and DBP and daytime SBP and DBP did not differ between groups (table 2). 
Table 2. Baseline and run-in characteristics $(n=94)^{1}$.

\begin{tabular}{|c|c|c|c|}
\hline & Protein & Maltodextrin & P value \\
\hline Participants, $\mathrm{n}$ & 43 & 51 & \\
\hline Women, n, (\%) & $14(33)$ & $16(31)$ & \\
\hline $\mathrm{BMI}, \mathrm{kg} / \mathrm{m}^{2}$ & $27.9 \pm 0.4^{2}$ & $28.8 \pm 0.4$ & $0.11^{3}$ \\
\hline Age, yr & $55.3 \pm 1.1$ & $55.0 \pm 1.3$ & $0.90^{3}$ \\
\hline $\mathrm{SBP}, \mathrm{mmHg}$ & $147.7 \pm 1.9$ & $150.1 \pm 2.0$ & $0.41^{3}$ \\
\hline $\mathrm{DBP}, \mathrm{mmHg}$ & $95.9 \pm 1.1$ & $97.1 \pm 1.1$ & $0.45^{3}$ \\
\hline Fasting glucose, $\mathrm{mmol} / \mathrm{L}$ & $5.4 \pm 0.1$ & $5.6 \pm 0.1$ & $0.045^{3}$ \\
\hline \multicolumn{4}{|l|}{ Plasma creatinine, $\mu \mathrm{mol} / \mathrm{L}$} \\
\hline Men & $86.0 \pm 1.7$ & $86.1 \pm 2.0$ & $0.96^{3}$ \\
\hline Women & $70.7 \pm 2.2$ & $69.8 \pm 2.6$ & $0.78^{3}$ \\
\hline Run-in office SBP, $\mathrm{mmHg}$ & $143.3 \pm 1.8$ & $142.5 \pm 1.6$ & $0.76^{3}$ \\
\hline Run-in office DBP, mmHg & $92.9 \pm 1.0$ & $92.2 \pm 0.9$ & $0.63^{3}$ \\
\hline Run-in daytime SBP, $\mathrm{mmHg}^{4}$ & $147.0 \pm 1.4$ & $147.9 \pm 1.3$ & $0.64^{5}$ \\
\hline Run-in daytime $\mathrm{DBP}, \mathrm{mmHg}^{4}$ & $92.7 \pm 0.9$ & $91.3 \pm 0.8$ & $0.21^{5}$ \\
\hline Run-in daytime $H R$, beats $/ \mathrm{min}^{4}$ & $73.7 \pm 1.1$ & $74.3 \pm 1.0$ & $0.69^{5}$ \\
\hline \multicolumn{4}{|c|}{$\begin{array}{l}{ }^{1} \text { DBP, diastolic blood pressure; SBP, systolic blood pressure. } \\
{ }^{2} \text { mean } \pm \text { SE (all such values). } \\
{ }^{3} \text { from independent-samples } t \text { test for between-group differences. } \\
{ }^{4} \text { daytime was from } 9.30 \text { to } 21.30\end{array}$} \\
\hline
\end{tabular}

\section{Body weight}

Repeated-measures analysis showed no significant weight changes $(P=0.99)$ during the intervention. Body weight did not differ between groups during the intervention, with mean values of $85.9 \mathrm{~kg}$ in the maltodextrin group and $85.7 \mathrm{~kg}$ in the protein group $(P=$ $0.35)$.

\section{Office BP}

All between-group differences after 4 wk discussed in the next 3 paragraphs were tested with corrections for run-in values. Office SBP and DBP at run-in and after the intervention are shown in figure 2. Office SBP was $4.9 \pm 1.7 \mathrm{mmHg}(95 \% \mathrm{Cl} 1.5,8.2 \mathrm{mmHg})$ lower in the protein group than in the maltodextrin group $(P=0.005)$ after 4 wk supplementation. DBP was $2.7 \pm 1.3 \mathrm{mmHg}(95 \% \mathrm{Cl} 0.1,5.4 \mathrm{mmHg})$ lower $(P=0.05)$ after $4 \mathrm{wk}$. Analysis of completers included 2 subjects in the protein group who missed their endpoint measurement after 4 wk. BP at the end of week 4 in these subjects was estimated from BP changes in the rest of the protein group from weeks 3 to 4 . When the last-observationcarried-forward procedure was applied for these 2 subjects, similar results were obtained (not shown). Mixed-model analyses in all 99 subjects who were randomly assigned, which, thus, included the dropouts, resulted in the same conclusions as in the analyses of 

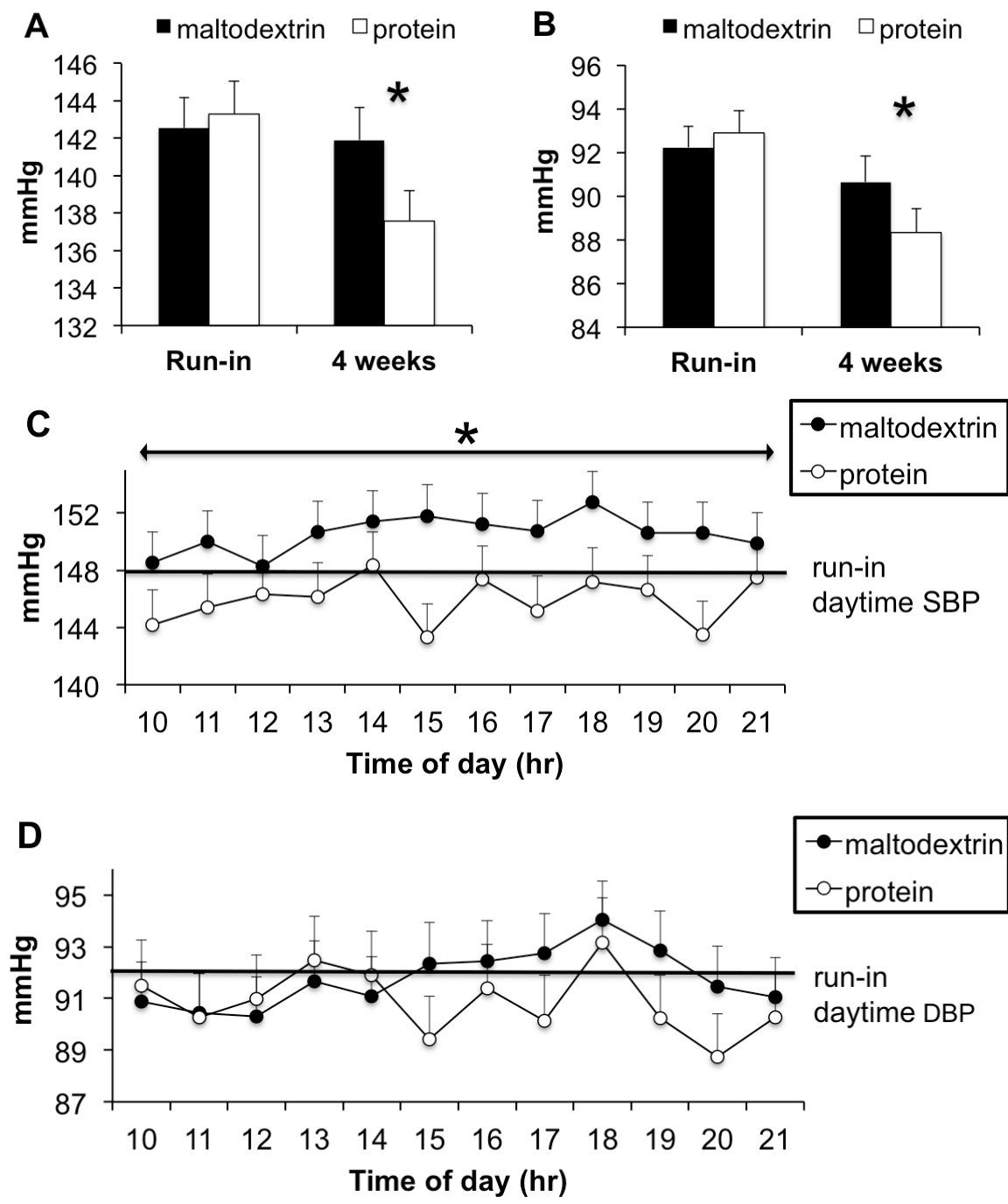

Figure 2. Maltodextrin group (black, $n=51$ ) and protein group (white, $n=43$ ). Between-group differences in office BP after 4 weeks were analyzed by using ANCOVA with run-in as a covariate. Displayed office SBP (A) and DBP (B) values were the uncorrected group means and SEs. Between-group differences in daytime BP values were analyzed by using a mixed-model analysis with run-in daytime BP as a covariate. Displayed daytime SBP (C) and DBP (D) values are variable estimates and SEs corrected for run-in daytime BP. $* P<0.05$. BP, blood pressure; DBP, diastolic blood pressure; SBP, systolic blood pressure. 
Table 3. 24-h urinary excretions after run-in and after 4 weeks ${ }^{1}$

\begin{tabular}{|c|c|c|c|c|c|c|c|c|}
\hline & \multicolumn{3}{|c|}{ Run-in ${ }^{2}$} & \multicolumn{5}{|c|}{4 weeks } \\
\hline & $\mathbf{P}$ & M & $\mathrm{P} / \mathrm{M}^{3}$ & $\mathbf{P}$ & M & $\begin{array}{c}\text { difference P-M } \\
(95 \% \mathrm{CI})\end{array}$ & $\boldsymbol{P}$ & $\mathrm{P} / \mathrm{M}^{3}$ \\
\hline \multicolumn{9}{|l|}{ 24-h urinary excretion } \\
\hline Urea, mmol/day & $442 \pm 15^{4}$ & $437 \pm 15$ & $41 / 48$ & $631 \pm 24$ & $424 \pm 18$ & $206(155,257)$ & $<0.001^{5}$ & $41 / 45$ \\
\hline Sulfate, $\mathrm{mmol} / \mathrm{day}$ & $20 \pm 0.8$ & $20 \pm 0.8$ & $41 / 48$ & $27 \pm 1.0$ & $19 \pm 0.9$ & $8(6,11)$ & $<0.001^{5}$ & $41 / 45$ \\
\hline Sodium, mmol/day & $174 \pm 11$ & $169 \pm 7$ & $41 / 48$ & $175 \pm 9$ & $214 \pm 12$ & $-42(-70,-14)$ & $0.004^{5}$ & $41 / 45$ \\
\hline Potassium, mmol/day & $86 \pm 4$ & $81 \pm 3$ & $41 / 48$ & $74 \pm 3$ & $80 \pm 3$ & $-8(-17,0)$ & 0.06 & $41 / 45$ \\
\hline Calcium, $\mathrm{mmol} / \mathrm{day}$ & $5 \pm 0.3$ & $5 \pm 0.4$ & $35 / 43$ & $6 \pm 0.4$ & $5 \pm 0.4$ & $0.8(-0.1,1.7)$ & 0.07 & $35 / 40$ \\
\hline Magnesium, mmol/day & $5 \pm 0.2$ & $5 \pm 0.2$ & $41 / 48$ & $5 \pm 0.2$ & $5 \pm 0.2$ & $0.1(-0.4,0.7)$ & 0.59 & $41 / 45$ \\
\hline Phosphate, mmol/day & $30 \pm 1$ & $30 \pm 1$ & $41 / 48$ & $31 \pm 1$ & $35 \pm 2$ & $-3(-7,1)$ & 0.10 & $41 / 45$ \\
\hline Creatinine, $\mathrm{mmol} / \mathrm{day}$ & $13 \pm 0.5$ & $14 \pm 0.5$ & $41 / 48$ & $13 \pm 0.5$ & $14 \pm 0.6$ & $0.2(-1.0,1.3)$ & 0.78 & $41 / 45$ \\
\hline Albumin, Q1-Q2-Q3; mg/L & $2-4-9$ & $2-4-8$ & $41 / 48$ & $1-4-8$ & $3-6-13$ & - & 0.05 & $43 / 46$ \\
\hline
\end{tabular}

$1 \mathrm{P}$ values of between-group differences were calculated by using ANCOVA with run-in as a covariate. $M$, maltodextrin group; $P$, protein group; $Q$, quartile.

2 none of the differences between groups were significant after the run-in period $(P>0.05)$ on the basis of an independent-sample $t$ test (for urea, sulfate, sodium, potassium, calcium, magnesium, phosphate, creatinine) or Mann-Whitney $U$ test (for albumin).

3 number of subjects included in the analysis, which was lower than the number of participants because of missing values

4 mean \pm SE (all such values).

$5 \mathrm{P}<0.05$.

completers. The effect of supplementation on SBP and DBP was not influenced by hypertension status ( $P=0.47$ and $P=0.07$, respectively).

\section{Daytime SBP, DBP and $H R$}

After 4 wk supplementation, daytime SBP was $4.6 \pm 1.7 \mathrm{mmHg}(95 \% \mathrm{Cl} 1.3,7.9 \mathrm{mmHg})$ lower in the protein group than in the maltodextrin group $(P=0.006)$, whereas daytime DBP was comparable in both groups $(P=0.43,95 \% \mathrm{Cl}-3.2,1.4 \mathrm{mmHg})$. The betweengroup difference in daytime SBP appeared to be as much due to an increase in the maltodextrin group as to a decrease in the protein group (figure 2). The daytime HR was not different between groups after 4 wk supplementation ( $P=0.52$, data not shown).

\section{4-hour urinary excretions}

Run-in 24-h urine excretions did not differ between groups (table 3). Urinary markers of protein intake (urea and sulfate excretion) were significantly higher in the protein group after 4 wk supplementation $(P<0.001$, both). Sodium excretion at $24 \mathrm{~h}$ was significantly lower in the protein group than in the maltodextrin group $(P=0.004)$. Potassium excretion at $24 \mathrm{~h}$ tended to be lower in the protein group $(P=0.06)$ whereas $24 \mathrm{~h}$ calcium excretion 
tended to be higher in the protein group $(P=0.07)$. Albumin excretion tended to be higher in the maltodextrin group $(P=0.05)$. None of the other urinary excretions differed significantly between groups after 4 wk supplementation (table 3 ).

When only subjects with a $<20 \%$ change in $24-h$ urinary creatinine excretion $(n=33$ protein, $n=32$ maltodextrin) were analyzed, between-group differences in 24- $h$ potassium, phosphate and albumin excretion became significant. Potassium and phosphate excretion were $9 \pm 4 \mathrm{mmol} / \mathrm{d}(P=0.03)$ and $4 \pm 2 \mathrm{mmol} / \mathrm{d}(P=0.01)$ lower in the protein group. Albumin excretion was significantly lower in the protein group $(P=0.04$; first, second, and third quartiles of albumin excretion: maltodextrin group $=3,7$, and 13 ; protein group $=1,3$, and 7 ).

Changes in urinary sodium excretion over 4 wk did not significantly contribute to the initial model that explained group differences in 4-wk office BP corrected for run-in office BP $(P$ $=0.35$ for SBP, $P=0.69$ for DBP).

\section{DISCUSSION}

The PROPRES trial aimed to investigate whether a moderately increased protein intake ( $+10 \%$ of energy) compared with isocalorically increased maltodextrin intake for $4 \mathrm{wk}$ lowers BP in overweight individuals with upper-range prehypertension or grade 1 hypertension. Increased protein consumption was shown to significantly decrease office SBP by $4.9 \mathrm{mmHg}$ and DBP by $2.7 \mathrm{mmHg}$ compared with maltodextrin intake. In addition, daytime SBP was $4.6 \mathrm{mmHg}$ lower in the protein group. If a reduction of $5 \mathrm{mmHg}$ in office SBP would be attained at the population level a $14 \%$ risk reduction in stroke mortality and a $9 \%$ risk reduction in coronary heart disease mortality are expected (14). Trials that study the effects of BP-lowering antihypertensive agents have also shown risk reductions of 15$22 \%$ for major cardiovascular events with modest decreases in BP (15).

The findings in the PROPRES trial are in agreement with those from other large randomized trials that investigated the effects of protein intake on BP $(9,16-18)$. The effects of an increased protein intake on SBP and DBP in the PROPRES trial were larger than those shown in the OmniHeart trial $(\triangle \mathrm{SBP}=-1.4 \mathrm{mmHg} ; \triangle \mathrm{DBP}=-1.2 \mathrm{mmHg}$ ) (9) and in the recently published study by He et.al. 2011 (16) ( $\triangle \mathrm{SBP}-2.0 \mathrm{mmHg}$ for soy-protein isolate and $-2.3 \mathrm{mmHg}$ for milk-protein isolate). Differences in BP-lowering effects of protein may be due to the use of different control foods. The PROPRES trial and the study by $\mathrm{He}$ et al (16) used complex carbohydrate supplements as a control, whereas control diets in the OmniHeart trial consisted of carbohydrates from different food sources (9). The larger effects shown in the PROPRES trial may also be explained by the higher average $B P$ in our study population. The PROPRES trial included participants with SBP $\geq 130 \mathrm{mmHg}$, 
whereas the other 2 studies also included subjects with SBP of $120-129 \mathrm{mmHg}(9,16)$. It is not likely that the larger effects shown in PROPRES were due to the duration of the intervention. Although the PROPRES intervention lasted 4 weeks compared with 6 weeks (9) and 8 (16) wk in the OmniHeart trial (9) and the study by He et al (16), respectively, a study by Pal and Ellis (19) showed that reductions in SBP remained stable from 6 to $12 \mathrm{wk}$ of supplementation, and DBP even showed an additional reduction. In the PROPRES trial, the protein supplement was $60 \mathrm{~g} / \mathrm{d}$, whereas in the study of He et al (16) the protein supplement was $40 \mathrm{~g} / \mathrm{d}$. A final reason why effects in the PROPRES study may be larger is the higher sodium excretion in the maltodextrin group after the 4-wk intervention, although changes in sodium excretion during the intervention did not significantly contribute to our model that explained office BP after $4 \mathrm{wk}$. Dietary sodium intake is positively associated with BP (20). An increased sodium intake is likely to explain at least part of the difference in sodium excretion in the PROPRES study. Although sodium intake from the supplements was slightly higher in the maltodextrin group, the extra $6 \mathrm{mmol}$ sodium/d (table 1) from maltodextrin supplements could not explain the $42 \mathrm{mmol}$ sodium/d higher excretion in the maltodextrin group. We could not fully exclude possible confounding effects from dietary differences between groups in the PROPRES study. Measures of compliance were urinary nitrogen and sulfate excretion, which confirmed that subjects in the protein group consumed more protein than did subjects in the maltodextrin group. Incomplete urine collection did not explain the higher sodium excretion in the maltodextrin group because the difference remained significant when only subjects with a change in $24-\mathrm{h}$ urinary creatinine below $20 \%$ were included in the analysis.

Urinary potassium and phosphate tended to be lower in the protein group, and calcium excretion tended to be higher in the protein group than in the maltodextrin group. $A$ calciuretic effect of protein consumption has previously been shown $(21,22)$. An important concern of high protein intake is the possibility of kidney damage (23), especially in individuals at risk of renal disease (24). This study showed no short-term adverse changes in urinary albumin excretion in the protein group, which is in agreement with another recent study (25). Albumin excretion even tended to be higher in the maltodextrin group compared to the protein group after the intervention.

A limitation of this study was the inability to distinguish the effects of increased protein consumption from the effects of decreased carbohydrate consumption. This problem was inevitable, because an increased intake of one macronutrient will always result in a decreased intake of at least one of the other macronutrients under isocaloric conditions (10). Supplements were well tolerated by most participants. Two of the 48 subjects in the protein group (4\%) experienced adverse effects. One participant felt bloated after consumption of the protein supplement, whereas the other participant experienced 
nausea. Adverse feelings disappeared when the participants stopped consuming supplements.

A strength of this study was that the effects of isolated proteins and carbohydrates, rather than the effects of protein- and carbohydrate-rich foods, were tested, which strengthened the conclusion that it was the increase in protein intake (or reduction in carbohydrate intake) that was responsible for the BP reduction. Because the supplements were matched for micronutrients, confounding effects by these minerals were limited. In addition, body weight was controlled for throughout the whole intervention to avoid a confounding effect of weight changes on BP (26). Both the OmniHeart (9) and Diogenes (27) trials have shown that an increase in protein intake to $25 \%$ of energy is feasible with normal foods. However, it is hard to predict whether such dietary changes that do not involve protein supplementation will lead to comparable results to those shown in the PROPRES study because protein rich foods also contain other macronutrients and micronutrients, which may affect BP.

In conclusion, the PROPRES study shows that BP can be lowered by increasing the intake of proteins in exchange for carbohydrates in the context of an isocaloric weightmaintaining diet for $4 \mathrm{wk}$ in overweight subjects with upper-range prehypertension and grade 1 hypertension.

\section{ACKNOWLEDGEMENTS}

We thank all study participants for their contributions to the trial. In addition, we thank Harrie Robins and Jeroen Smets for help in the PROPRES trial.

TI Food and Nutrition, which supported this study, is a public private partnership of science, industry, and government that conducts strategic research in food and nutrition (http://www.tifn.nl).

The authors' responsibilities were as follows - MAvB, EJB, JMG, PWdL and SJLB: designed the study; JD, KFMT-B, MAvB: conducted the study; KFMT-B and MAvB: analyzed the data; KFMT-B, MAvB, JD, EJB, JMG, PWdL and SJLB: wrote the manuscript; MAvB: assumed primary responsibility for the final content of the manuscript; and all authors read and approved the final version of the manuscript. None of the authors had a conflict of interest. 


\section{REFERENCES}

1. Stamler J, Elliott P, Kesteloot H, Nichols R, Claeys G, Dyer AR, et al. Inverse relation of dietary protein markers with blood pressure. Findings for 10,020 men and women in the INTERSALT Study. INTERSALT Cooperative Research Group. INTERnational study of SALT and blood pressure. Circulation. 1996;94(7):1629-34.

2. Stamler J, Caggiula A, Grandits GA, Kjelsberg M, Cutler JA. Relationship to blood pressure of combinations of dietary macronutrients. Findings of the Multiple Risk Factor Intervention Trial (MRFIT). Circulation. 1996;94(10):2417-23.

3. Wang YF, Yancy WS, Jr., Yu D, Champagne C, Appel LJ, Lin PH. The relationship between dietary protein intake and blood pressure: results from the PREMIER study. J Hum Hypertens. 2008;22(11):745-54.

4. Elliott P, Stamler J, Dyer AR, Appel L, Dennis B, Kesteloot H, et al. Association between protein intake and blood pressure: the INTERMAP Study. Arch Intern Med. 2006;166(1):79-87.

5. Burke V, Hodgson JM, Beilin L, Giangiulioi N, Rogers P, Puddey IB. Dietary protein and soluble fiber reduce ambulatory blood pressure in treated hypertensives. Hypertension. 2001;38(4):821-6.

6. Hodgson JM, Burke V, Beilin LJ, Puddey IB. Partial substitution of carbohydrate intake with protein intake from lean red meat lowers blood pressure in hypertensive persons. Am J Clin Nutr. 2006;83(4):780-7.

7. Brinkworth GD, Noakes M, Parker B, Foster P, Clifton PM. Long-term effects of advice to consume a high-protein, low-fat diet, rather than a conventional weight-loss diet, in obese adults with type 2 diabetes: one-year follow-up of a randomised trial. Diabetologia. 2004;47(10):1677-86.

8. Ferrara LA, Innelli P, Palmieri V, Limauro S, De Luca G, Ferrara F, et al. Effects of different dietary protein intakes on body composition and vascular reactivity. Eur J Clin Nutr. 2006;60(5):643-9.

9. Appel LJ, Sacks FM, Carey VJ, Obarzanek E, Swain JF, Miller ER, 3rd, et al. Effects of protein, monounsaturated fat, and carbohydrate intake on blood pressure and serum lipids: results of the OmniHeart randomized trial. Jama. 2005;294(19):2455-64.

10. Altorf-van der Kuil W, Engberink MF, Brink EJ, van Baak MA, Bakker SJ, Navis G, et al. Dietary protein and blood pressure: a systematic review. PLoS One. 2010;5(8):e12102.

11. Hulshof KFAM, Ocké MC, van Rossum CTM, Buurma-Rethans EJM, Brants HAM, Drijvers JJMM, et al. Results of the national food consumption survey 2003 (Dutch). RIVM rapport 350030002/2004 [Internet]. 2004 [cited 2011 Jun 29]:[111 p.]. Available from: http://www.rivm.nl/bibliotheek/rapporten/350030002.html.

12. O'Brien E, Mee F, Atkins N, O'Malley K. Accuracy of the SpaceLabs 90207 determined by the British Hypertension Society protocol. J Hypertens. 1991;9(6):573-4.

13. Stuveling EM, Bakker SJ, Hillege HL, Burgerhof JG, de Jong PE, Gans RO, et al. C-reactive protein modifies the relationship between blood pressure and microalbuminuria. Hypertension. 2004;43(4):791-6.

14. Whelton PK, He J, Appel LJ, Cutler JA, Havas S, Kotchen TA, et al. Primary prevention of hypertension: clinical and public health advisory from The National High Blood Pressure Education Program. Jama. 2002;288(15):1882-8.

15. Turnbull F. Effects of different blood-pressure-lowering regimens on major cardiovascular events: results of prospectively-designed overviews of randomised trials. Lancet. 2003;362(9395):1527-35.

16. He J, Wofford MR, Reynolds K, Chen J, Chen CS, Myers L, et al. Effect of dietary protein supplementation on blood pressure: a randomized, controlled trial. Circulation. 2011;124(5):589-95.

17. Delbridge EA, Prendergast LA, Pritchard JE, Proietto J. One-year weight maintenance after significant weight loss in healthy overweight and obese subjects: does diet composition matter? Am J Clin Nutr. 2009;90(5):1203-14.

18. Muzio F, Mondazzi L, Harris WS, Sommariva D, Branchi A. Effects of moderate variations in the macronutrient content of the diet on cardiovascular disease risk factors in obese patients with the metabolic syndrome. Am J Clin Nutr. 2007;86(4):946-51.

19. Pal S, Ellis V. The chronic effects of whey proteins on blood pressure, vascular function, and inflammatory markers in overweight individuals. Obesity (Silver Spring). 2010;18(7):1354-9.

20. Sarkkinen ES, Kastarinen MJ, Niskanen TH, Karjalainen PH, Venalainen TM, Udani JK, et al. Feasibility and antihypertensive effect of replacing regular salt with mineral salt -rich in magnesium and potassium- in subjects with mildly elevated blood pressure. Nutr J. 2011;10:88.

21. Hunt JR, Johnson LK, Fariba Roughead ZK. Dietary protein and calcium interact to influence calcium retention: a controlled feeding study. Am J Clin Nutr. 2009;89(5):1357-65. 
22. Zhu K, Meng X, Kerr DA, Devine A, Solah V, Binns CW, et al. The effects of a two-year randomised controlled trial of whey protein supplementation on bone structure, IGF-I and urinary calcium excretion in older postmenopausal women. J Bone Miner Res. 2011;26(9):2298-306.

23. Bernstein AM, Treyzon L, Li Z. Are high-protein, vegetable-based diets safe for kidney function? A review of the literature. J Am Diet Assoc. 2007;107(4):644-50.

24. Fouque D, Laville M. Low protein diets for chronic kidney disease in non diabetic adults. Cochrane Database Syst Rev. 2009;(3):CD001892.

25. Jacobs DR, Jr., Gross MD, Steffen L, Steffes MW, Yu X, Svetkey LP, et al. The effects of dietary patterns on urinary albumin excretion: results of the Dietary Approaches to Stop Hypertension (DASH) Trial. Am J Kidney Dis. 2009;53(4):638-46.

26. Neter JE, Stam BE, Kok FJ, Grobbee DE, Geleijnse JM. Influence of weight reduction on blood pressure: a meta-analysis of randomized controlled trials. Hypertension. 2003;42(5):878-84.

27. Larsen TM, Dalskov SM, van Baak M, Jebb SA, Papadaki A, Pfeiffer AF, et al. Diets with high or low protein content and glycemic index for weight-loss maintenance. N Engl J Med. 2010;363(22):2102-13. 



\section{Chapter 4}

Blood pressure decreases more after highcarbohydrate meals than after high-protein meals in overweight adults with elevated blood pressure, but there is no difference after 4 weeks of consuming a carbohydrate-rich or protein-rich diet

J. Nutr. 2013 Apr; 143(4):424-9

Karianna F.M. Teunissen-Beekman

Janneke Dopheide Johanna M. Geleijnse Stephan J.L. Bakker Elizabeth J. Brink Peter W. de Leeuw Jan Serroyen Marleen A. van Baak 


\section{ABSTRACT}

The replacement of dietary carbohydrates with proteins can lower blood pressure (BP), but the mechanisms remain unclear. This randomized, double-blind, parallel-group study aimed to compare $12 \mathrm{~h}$ postprandial sympathetic and hemodynamic responses after highprotein (HP) meals and high-carbohydrate (HC) meals. Fifty-two men and women with untreated elevated BP were tested on $\mathrm{d} 1$ and after $4 \mathrm{wk}$ of supplementation $(3 \times 20 \mathrm{~g}$ protein (HP) or maltodextrin (HC) per day). No between-group differences were found in postprandial plasma norepinephrine on $\mathrm{d} 1$ and at wk 4 . On $\mathrm{d} 1$, postprandial mean arterial pressure (MAP) decreased more in the HC group than in the HP group $(P=0.002)$. This difference was not present at $4 \mathrm{wk}$, because the postprandial decline in MAP tended to become larger in the HP group after 4 wk of supplementation $(P=0.07)$. On both test days, postprandial total peripheral resistance tended to decrease more in the HC group ( $P$ $<0.08)$. After $4 \mathrm{wk}$ of supplementation, cardiac output tended to increase more in the $\mathrm{HC}$ group $(P=0.08)$. In conclusion, ingestion of an HP diet induced a smaller decrease in BP on d 1 than did ingestion of an $\mathrm{HC}$ diet. This difference disappeared after $4 \mathrm{wk}$ due to a more pronounced decrease in BP in the HP group after $4 \mathrm{wk}$ than on $\mathrm{d} 1$. These findings cannot explain the BP-lowering effect ascribed to dietary proteins. 


\section{INTRODUCTION}

The potential of dietary proteins to lower blood pressure (BP) could contribute to lifestyle modifications aimed at BP control in (pre)hypertensive patients. Although trials studying the effect of dietary proteins on BP have produced inconsistent results (1-5), the randomized clinical trial on the effects of PROteins on blood PRESsure (PROPRES) has shown that $4 \mathrm{wk}$ of protein supplementation is able to lower BP in overweight men and women with untreated elevated BP as compared with 4 wk of maltodextrin supplementation (6). A subgroup of the PROPRES participants participated in the present substudy addressing possible mechanisms involved in the BP-lowering effect of proteins. High postprandial levels of sympathetic nervous system (SNS) activation may be important in the development of high BP, because chronically elevated SNS activity plays a role in the onset of hypertension in obesity (7). Carbohydrate-supplemented meals may induce greater postprandial SNS activation as a result of a greater postprandial decrease in total peripheral resistance (TPR) compared with protein-supplemented meals. Although the mechanism is not fully known, insulin may be involved in decreasing the TPR (8), and increased SNS activation may be necessary to maintain BP. Few studies compared postprandial hemodynamics of meals with varying macronutrient composition (9-13). These studies reported no differences in postprandial BP responses between high-protein (HP) and high-carbohydrate (HC) meals $(9,11-13)$, but inconsistent findings with respect to cardiac output (CO) and TPR changes $(9,11)$.

We hypothesized that the postprandial activation of the SNS would be more pronounced after carbohydrate-supplemented meals, compared with protein-supplemented meals, to compensate for a greater decrease in TPR induced by glucose ingestion. This would result in similar postprandial BP levels after both meals. In addition, we were interested to see whether these responses would persist after consuming a diet high in protein versus a diet high in carbohydrate for $4 \mathrm{wk}$. The aim of this substudy was to compare changes in SNS activity and postprandial hemodynamics induced by protein- and carbohydrate- enriched meals. Postprandial responses were observed for $12 \mathrm{~h}$ (including breakfast, lunch, and dinner) at $\mathrm{d} 1$ and after $4 \mathrm{wk}$ of protein or maltodextrin supplementation in the PROPRES intervention study (6).

\section{PARTICIPANTS AND METHODS}

\section{Experimental design}

This study was conducted in a subgroup of participants in the PROPRES study, which compared the effects of $4 \mathrm{wk}$ protein supplementation to $4 \mathrm{wk}$ maltodextrin supplementation on BP in a parallel-group design. A more detailed description of the design of the PROPRES study with inclusion and exclusion criteria can be found elsewhere 
(6). All PROPRES participants were asked whether they wanted to take part in a substudy in which the postprandial effects of the supplements were investigated on 2 extra test days during the PROPRES intervention. This substudy was powered to significantly show between-group differences of at least $10 \%$ with an SD of $15 \%$ of group means and a power of 0.8 . Based on these values, 50 participants would be necessary. The aim was to recruit 60 participants to allow for a dropout of 10 participants. After a 2-wk run-in period, subjects were prestratified for systolic blood pressure (SBP; $<140 \mathrm{mmHg}, \geq 140 \mathrm{~mm} \mathrm{Hg}$ ), age $(<50 y, \geq 50 y)$, and sex and randomized for protein or maltodextrin supplementation with a computer program (14). Participants in the substudy were randomized separately from the PROPRES participants who did not take part in the substudy (supplemental fig. 1). This substudy was approved by the local medical ethics committee of the academic hospital Maastricht and Maastricht University. All participants gave written informed consent.

\section{Study protocol}

Participants in this substudy visited the university on $\mathrm{d} 1$ of supplementation and after 4 wk of supplementation for a test day in order to investigate the postprandial effects of the supplements. During these visits, participants arrived at the university at 0730 after an overnight fast and stayed until $2200 \mathrm{~h}$. Breakfast (1000), lunch (1400) and dinner (1800) were each supplemented with $20 \mathrm{~g}$ of the protein supplement in the HP group or with 20 $\mathrm{g}$ maltodextrin in the $\mathrm{HC}$ group. On the test days, measurements were taken at $0 \mathrm{~min}$ (before breakfast) and 30, 60, 90, 120, 180, 240, 300, 360, 420, 480, 540, 600, 660, and $720 \mathrm{~min}$ after breakfast. The main outcome measure was plasma norepinephrine (NE).

The meals served during the test days (supplemental table 1 ) were adapted to individual daily energy needs, which were calculated with the revised Harris and Benedict equation (15) multiplied by 1.3. Supplement drinks were prepared in nontransparent cups by a research assistant who was not involved in the measurements. The composition of the supplements can be found in supplemental table 2 .

\section{SNS activity}

SNS activity was estimated by assessment of venous plasma norepinephrine (NE) and epinephrine (E). Venous blood was collected in EDTA-coated vials. Blood was centrifuged at $4^{\circ} \mathrm{C}, 1000 \times \mathrm{g}$ for $10 \mathrm{~min}$ to acquire plasma, which was stored at $-80^{\circ} \mathrm{C}$ until further analyses. Plasma catecholamines were analyzed by the Dutch organization for Applied Scientific Research, TNO (16).

Urine was collected before each meal and at the end of the test day. The volume was recorded and aliquots stored at $-80^{\circ} \mathrm{C}$ until further analyses. Urinary catecholamine concentrations were analyzed by liquid chromatography-MS at the University Medical 
Center Groningen. The amount of $\mathrm{E}$ and NE excreted during the first $4 \mathrm{~h}$ after each meal was calculated by multiplying urinary concentrations by the volume of excreted urine. The preprandial values from the first urine collection were expressed per mole creatinine excretion because the first urine sample did not represent a standard time period.

\section{$B P$ and heart rate}

At each time point, $B P$ and heart rate $(H R)$ were measured twice with a validated automated BP measuring device (OMRON 6 comfort; Omron Healthcare Europe B.V.) in a semisupine position. The mean was used for further analysis. Mean arterial pressure (MAP) was calculated from SBP and diastolic blood pressure (DBP) with the following formula:

$$
M A P=D B P+1 / 3 \cdot(S B P-D B P) .
$$

$C O, T P R$, and stroke volume

$\mathrm{CO}$ was measured noninvasively with the Finometer midi and Beatscope easy software (Finapres Medical Systems B.V.) (17). TPR was derived from MAP and CO with the following formula:

$$
\operatorname{TPR}\left(\mathrm{mmHg} \cdot \min \cdot \mathrm{L}^{-1}\right)=\mathrm{MAP} / \mathrm{CO} \text {. }
$$

Stroke volume (SV) was calculated as:

$$
\mathrm{SV}(\mathrm{mL})=\mathrm{CO}\left(\mathrm{L} \cdot \mathrm{min}^{-1}\right) \cdot \mathrm{HR}\left(\text { beats } \cdot \mathrm{min}^{-1}\right)^{-1} \cdot 10^{3} \text {. }
$$

\section{Forearm blood flow}

Forearm blood flow (FBF) was measured with venous occlusion strain-gauge plethysmography (Hokanson EC6; Jordan Medical B.V.). During measurement, blood flow through the hand was excluded with a wrist cuff, which was inflated to $220 \mathrm{mmHg}$. Means of all measurement cycles were included in analyses if at least 3 cycles were available.

\section{Glucose and Insulin}

Blood drawn from the antecubital vein was collected in a tube containing sodium-fluoride for determination of plasma glucose and in a serum tube for assessment of serum insulin. Blood in the sodium-fluoride tube was immediately centrifuged at $4^{\circ} \mathrm{C}, 1000 \mathrm{x}$ g for 10 min, whereas the serum tube was kept at room temperature for $20 \mathrm{~min}$ before centrifugation. Plasma and serum were taken and immediately stored at $-80^{\circ} \mathrm{C}$ until analysis. Plasma glucose was analyzed with the glucose/HK assay (Roche Diagnostics), and serum insulin was determined with an electrochemiluminescence immunoassay (Roche Diagnostics) by MLM Medical Labs (Mönchengladbach, Germany). Serum insulin is expressed in $\mathrm{mU} \cdot \mathrm{L}^{-1}$. Values can be converted to $\mathrm{pmol} \cdot \mathrm{L}^{-1}$ by multiplying by 6.945 . 


\section{Statistical analyses}

Baseline characteristics were tested for between-group differences with an independentsamples $t$ test. Between-group differences in weight changes were tested for a group*time interaction by a repeated-measures ANCOVA model.

Postprandial data were analyzed by a linear mixed model, separately on each test day. The basic model consisted of a random intercept and the following fixed-effects variables: intercept, group, time (as a discrete variable), and the preprandial measurement on that test day. Additional covariates were added to the model one-by-one in the order age, sex, BMI. Covariates with a P-value $<0.10$ based on the likelihood ratio test were kept in the model. The final models are summarized in supplemental table 3.

Skewed distributions of FBF, NE, E, and serum insulin were normalized by transformation of these variables to their natural logarithms (In) for the statistical analyses. Betweengroup differences of In-transformed data are expressed in percentages calculated as $\%$ difference $=100\left(e^{\text {(difference) }}-1\right)$ with difference being the difference in the means of Intransformed data, i.e. $\ln$ (HC group) - In(HP group).

Incremental AUCS (iAUCs) were calculated to test for changes in postprandial responses over 4 wk. Changes in iAUCs were tested by repeated-measures ANOVA.

To test whether the responses of TPR were related to the serum insulin responses, Pearson correlation coefficients between changes in TPR and changes in insulin during the test days were calculated within each participant. Changes were calculated for each subject by subtracting the preprandial value from the individual postprandial values. The mean of all Pearson correlation coefficients was tested for deviation from zero by a 1sample t test.

To check whether postprandial responses were significant changes from the preprandial measurement, the iAUCs were tested for deviations from zero with a 1-sample t test.

All analyses were performed with SPSS software (version 19.0; IBM). A $P$ value smaller than 0.05 was considered to be significant.

\section{RESULTS}

\section{Participants}

Fifty-six participants were randomly assigned (Supplemental fig. 1). Three participants in the HP group and 1 in the HC group dropped out after randomization. In the HP group, 1 participant stopped because he felt unwell immediately after consumption of the supplement. One participant started with antihypertensive medication within $1 \mathrm{wk}$ after $\mathrm{d}$ 1 of the study, and 1 participant stopped for personal reasons not related to the intervention. The participant who dropped out in the HC group was not able to come to the test day after $4 \mathrm{wk}$ of supplementation due to illness not related to the supplements. 
Table 1. Baseline characteristics of the HP and HC group. ${ }^{1}$

\begin{tabular}{lccc}
\hline & HP & HC & P value \\
\hline Participants, $\mathrm{n}$. & 25 & 27 & \\
Women, $\mathrm{n}, \%$ & 7,28 & 7,26 & 0.33 \\
$\mathrm{BMI}, \mathrm{kg} / \mathrm{m}^{-2}$ & $28 \pm 1$ & $29 \pm 1$ & 0.76 \\
Age, $\mathrm{y}$ & $54 \pm 2$ & $55 \pm 2$ & 0.05 \\
Fasting plasma glucose, $\mathrm{mmol}^{-1}{ }^{-1}$ & $5.4 \pm 0.5$ & $5.7 \pm 0.6$ & 0.21 \\
SBP, mmHg & & & 0.57 \\
$\quad$ Screening & $146 \pm 3$ & $151 \pm 3$ & $145 \pm 3$ \\
$\quad$ Run-in & $143 \pm 2$ & & 0.20 \\
DBP, $\mathrm{mmHg}$ & & $98 \pm 1$ & 0.59 \\
$\quad$ Screening & $96 \pm 1$ & $94 \pm 1$ & \\
$\quad$ Run-in & $93 \pm 1$ & & \\
\hline
\end{tabular}

${ }^{1}$ Values are mean \pm SE unless stated otherwise. DBP, Diastolic blood pressure; HC, high carbohydrate group; $\mathrm{HP}$, high protein group; SBP; systolic blood pressure.

\section{Baseline characteristics}

Fifty-two participants were included in the analyses. Baseline characteristics were comparable between groups (Table 1). Body weight increased by $0.4 \pm 0.1 \mathrm{~kg}$ during the intervention $(P=0.002)$. This change was similar in both groups.

\section{Meal-induced changes}

IAUCs revealed no significant changes in plasma $N E$ and $E$, whereas postprandial concentrations of plasma glucose and serum insulin were significantly elevated compared with preprandial concentrations $(P<0.001)$. This was accompanied by a significant postprandial decrease in TPR $(P<0.008)$. The subsequent postprandial decreases in SBP, $\mathrm{DBP}$, and MAP (HC group, d 1 and wk 4; HP group, only 4 wk; $P<0.008$ ) were only partly compensated for by the significant postprandial increase in $\mathrm{CO}(P<0.02)$. The postprandial increase in CO was mainly due to the increased HR $(P<0.001)$, whereas SV did not change significantly. Postprandial FBF was significantly elevated after HP at 4 wk ( $P$ $<0.002)$.

\section{Differences in meal-induced responses between diet groups on $d 1$}

Postprandial responses in SNS activity, as reflected by NE concentrations, did not differ significantly between groups on $d 1$ (fig. 1A), whereas postprandial plasma $E$ concentrations tended to be $11 \%$ lower in the $\mathrm{HC}$ group $(P=0.06$, fig. $1 \mathrm{~B})$. In addition, urinary E excretion tended to be $0.9 \pm 0.5 \mathrm{nmol} \cdot 4 \mathrm{~h}^{-1}$ lower in the $\mathrm{HC}$ group $(P=0.09)$. On $\mathrm{d}$ 1 , plasma glucose and serum insulin concentrations increased more after the $\mathrm{HC}$ meals than after the HP meals ( $P<0.001$, fig. $1 K$, L, respectively). The higher serum insulin 

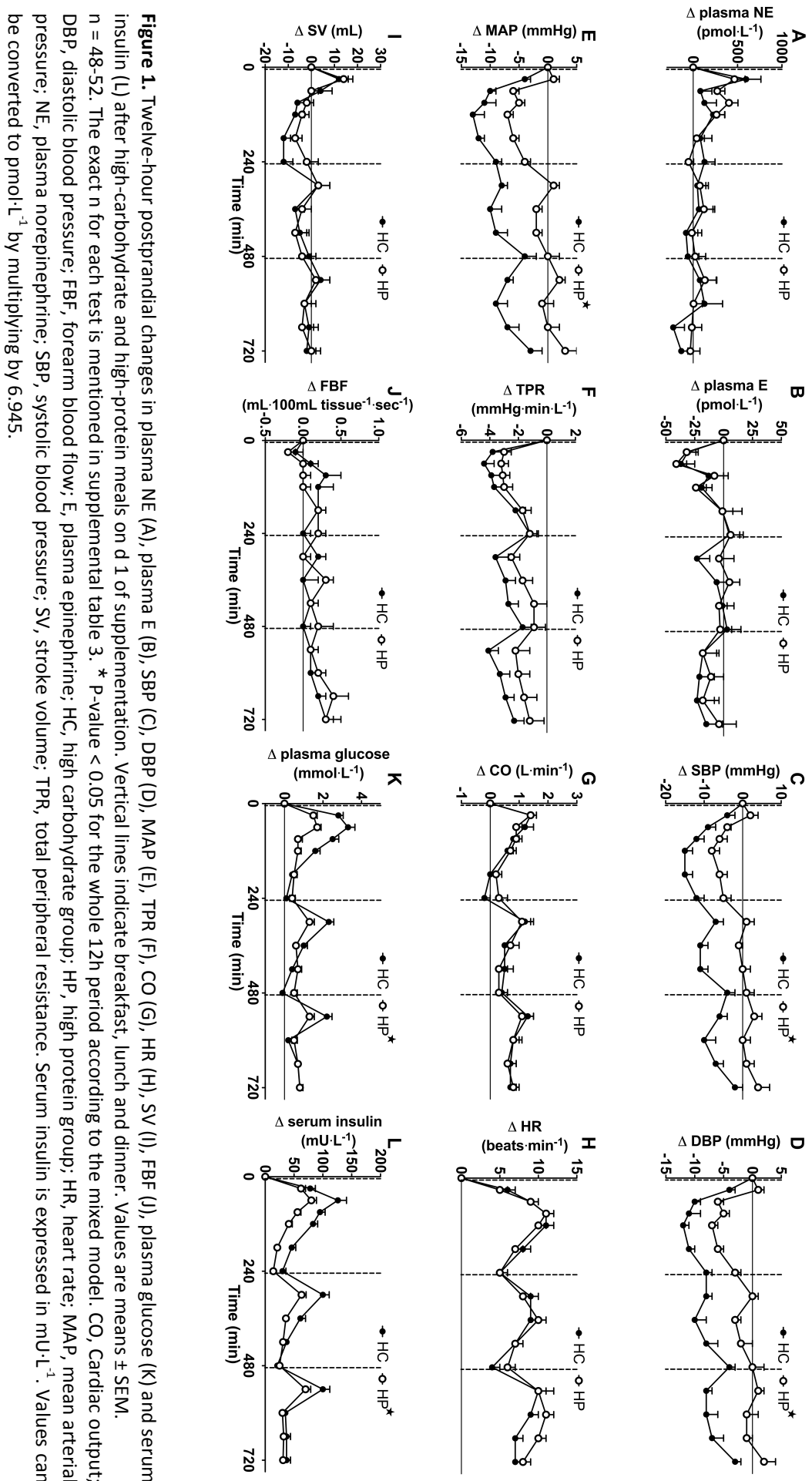
concentration in the $\mathrm{HC}$ group was accompanied by a $1.1 \pm 0.6 \mathrm{mmHg} \cdot \mathrm{min} \cdot \mathrm{L}^{-1}$ larger postprandial reduction in TPR in this group as compared with the HP group $(P=0.05$, fig. 1F). Postprandial CO, HR, and SV responses did not differ significantly between groups (fig. $1 \mathrm{G}-\mathrm{I}$, respectively). As a consequence, SBP, DBP, and MAP decreased $3.6 \pm 1.6 \mathrm{mmHg}, 3.6$ $\pm 1.3 \mathrm{mmHg}$ and $3.9 \pm 1.2 \mathrm{mmHg}$ more in the HC group than in the HP group $(P<0.03$, fig. $1 \mathrm{C}-\mathrm{E}$ respectively). Postprandial FBF was similar between groups (fig. 1J).

\section{Changes in meal-induced responses over the 4-wk intervention period}

Postprandial plasma NE and $E$ did not differ between groups after 4 wk of supplementation (fig. 2A, B respectively) nor did the urinary excretions of NE and E. After $4 \mathrm{wk}$ of supplementation, between-group differences in plasma glucose and insulin were maintained $(P<0.006$, fig. $2 \mathrm{~K}, \mathrm{~L}$, respectively). TPR tended to decrease $1.0 \pm 0.5$ $\mathrm{mmHg} \cdot \mathrm{min} \cdot \mathrm{L}^{-1}$ more in the $\mathrm{HC}$ group $(P=0.07$, fig. $2 \mathrm{~F})$. However, after exclusion of 1 outlier with an extremely high fasting TPR in the HP group, TPR decreased significantly more in the HC group compared with the HP group $(P=0.01)$. CO tended to increase 0.4 $\pm 0.2 \mathrm{~L} \cdot \mathrm{min}^{-1}$ more in the HC group ( $P=0.08$, fig. $2 \mathrm{G}$ ), although HR and SV did not differ significantly after 4 wk of supplementation (fig. $2 \mathrm{H}, \mathrm{I}$ respectively). Reductions in SBP and MAP were no longer significantly different after $4 \mathrm{wk}$ (fig. 2C, E respectively). DBP tended to decrease $2.0 \pm 1.1 \mathrm{mmHg}$ more in the $\mathrm{HC}$ group $(P=0.07$, fig. $2 \mathrm{D})$. Longitudinal analyses of iAUCs revealed a significant between-group difference in the change of the response of SBP over $4 \mathrm{wk}$ and a tendency for different changes in MAP over 4 wk $(P<0.06)$. Disappearance of the difference in SBP and MAP responses between groups appeared to be due to a more pronounced reduction in SBP and MAP after 4 wk of supplementation in the HP group compared with $\mathrm{d} 1$ ( $P=0.07$ for both).

\section{Association between meal-induced TPR and insulin responses}

Because between-group differences in the postprandial insulin response may contribute to the between-group differences in postprandial TPR, correlations between the changes in insulin and changes in TPR were tested. The mean of all individual correlation coefficients $\left(r_{\text {mean }}\right)$ was $-0.30 \pm 0.05$ on $d 1$ and $-0.39 \pm 0.04$ after 4 wk $(P<0.001)$.

\section{DISCUSSION}

Contrary to our hypothesis, this study did not show differences in SNS activation between meals supplemented with carbohydrates or proteins, and although the expected larger decrease in TPR after carbohydrate-supplemented meals was observed, the difference was not significant on either of the test days $(P<0.08)$. A possible contributor to the 

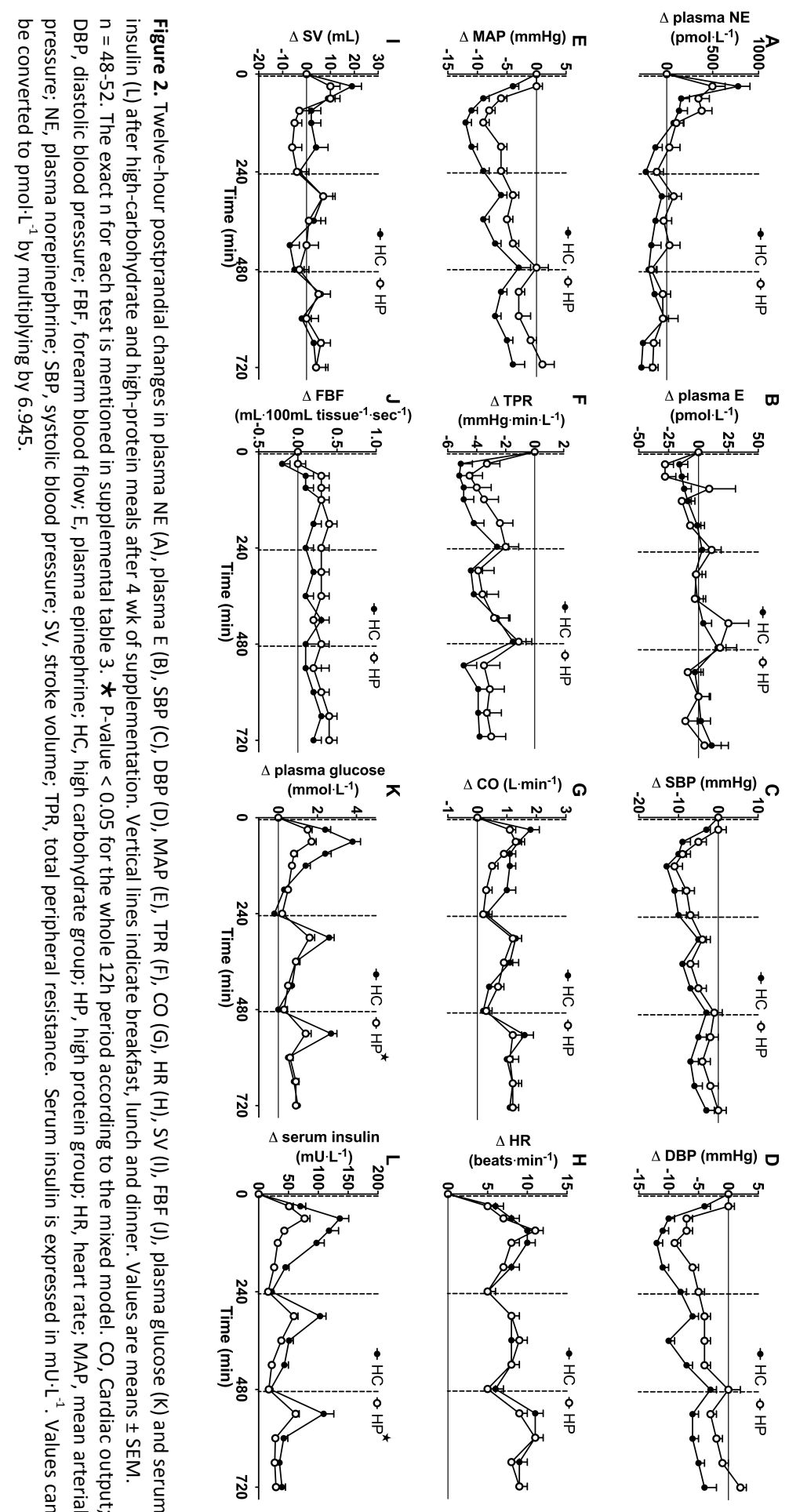
decrease in TPR is vasodilation in the splanchnic area. This is an acknowledged mechanism for increasing blood flow in this area to facilitate effective nutrient absorption from the gut (11). We hypothesized that TPR would decrease more after HC meals than after HP meals due to the larger insulin response after the carbohydrate-rich meals. Insulin induces NO-dependent vasodilation (8). Our data confirmed the larger decrease in TPR with consumption of the $\mathrm{HC}$ diet, although this was not significant on either of the test days ( $P$ $<0.08$ ), and the inverse association with the insulin response both acutely and after $4 \mathrm{wk}$. We further hypothesized that the BP response would be similar after the HC and HP meals. However, BP responses to the $\mathrm{HC}$ and $\mathrm{HP}$ meals were significantly different on $\mathrm{d} 1$. We found that meal ingestion reduced SBP, DBP, and MAP, with a significantly greater reduction in the $\mathrm{HC}$ group. Apparently, the postprandial decrease in TPR was only partly compensated for by an increase in $\mathrm{CO}$, resulting in a net decrease in BP in both groups. The larger BP reduction in the HC group on 11 could imply a less efficient baroreflex after the HC meals compared with the HP meals. This is in agreement with the finding that cardiac baroreflex sensitivity was reduced in middle-aged men and women with central obesity after a $75 \mathrm{~g}$ glucose load (18). However, it is in contrast with the finding that insulin increases baroreflex sensitivity in young men (19). Reduced baroreflex sensitivity may be a characteristic of our relatively old participants. A recently published study showed that isoenergetic meals high in carbohydrate or fat content induced a decrease in MAP within 60 min in elderly but not in younger persons, whereas HP meals did not reduce MAP (10). Differences in the postprandial release of the incretin hormone glucagon-like peptide-1 (GLP-1) may have contributed to the difference in postprandial BP between groups because GLP-1 is known to affect BP (20) and GLP-1 release can be modulated by diet (21). Differences in plasma osmolality after consumption of the 2 supplements may also have affected the BP response (22). However, we did not measure GLP-1 and osmolality in our study.

Previous studies on postprandial BP responses have suggested that SBP is maintained or even increased after food consumption $(18,23-28)$. However, decreases in MAP, SBP, and/or DBP have also been reported $(12,13,18,23-25,29-31)$. BP responses to a meal can vary depending on meal composition, meal size, and the individuals being studied. Studies comparing HP with $\mathrm{HC}$ meals did not report differences in postprandial BP responses between meals $(9,11-13)$. Three of these studies $(9,11,12)$ measured postprandial BP only for $1-2 \mathrm{~h}$ and included a small number of participants ( $\mathrm{n} \leq 10)$, which may explain why no significant differences were found. The fourth study, by Pal and Ellis (13), measured postprandial BP for $6 \mathrm{~h}$ and included 20 women. In this study the high fat content $(45 \%$ of energy) of the meals may have masked differences in postprandial BP between the $\mathrm{HC}$ and HP meals. Although the abovementioned studies, unlike ours, did not show a difference in postprandial BP responses between $\mathrm{HC}$ and HP meals, large postprandial decreases in BP 
after carbohydrate consumption have been described in persons with postprandial hypotension (32). After $4 \mathrm{wk}$ of supplementation, the between-group differences in postprandial BP had disappeared because the postprandial decrease in BP in the HP group had become larger after $4 \mathrm{wk}$ of supplementation, whereas the postprandial response after the carbohydrate-supplemented diet had not changed over 4 wk. Because other hemodynamic variables did not significantly change over 4 wk of supplementation, we cannot explain why the postprandial BP response declined in the HP group.

We expected lower postprandial SNS activity in the HP group, but this was not observed in the present study. Although postprandial NE was not significantly elevated, venous plasma NE concentrations showed postprandial patterns comparable to those reported by Penev et al. (33). No differences were found between our diet groups. Although plasma NE is an indicator of SNS activity, it only reflects whole-body sympathetic activation (34) and may be too insensitive to detect small differences in sympathetic activation on the whole-body level. In addition, it does not allow detection of regional differences in sympathetic activation (34), which are likely to be present(26). This is a clear limitation of our study. Another study looked at differences in muscle sympathetic nerve activity (MSNA) and found that the MSNA response was greater after glucose ingestion compared with after protein and fat ingestion. A mixed meal (44\% carbohydrate, 36\% fat, $20 \%$ protein) invoked an intermediate response, which did not differ from either the MSNA response to glucose or the responses to protein and fat (28). The tendency for a higher $\mathrm{CO}$ in the $\mathrm{HC}$ group after 4 wk $(P=0.08)$, although not reflected in higher HR and/or SV, could point to a higher level of sympathetic activation to the heart. Therefore, we cannot definitively exclude a differential level of sympathetic activation as a mechanism explaining the lower office BP and ambulatory BP in the HP group compared with the HC group in the overall PROPRES study (6).

This study has strengths and limitations. A strength of this study is that responses were measured during a whole day including 3 meals. Another strength is that the test days were conducted on $\mathrm{d} 1$ and after $4 \mathrm{wk}$ of supplementation to see whether differences between HP and HC meals would persist. A limitation of our study is that venous plasma catecholamines are not the most sensitive measure of SNS activity, but more direct measurements such as MSNA could not be implemented in our study protocol. Therefore, data on SNS activity after the HC and HP meals should be interpreted taking this limitation into account.

In conclusion, our data indicate that ingestion of an HP diet induces a smaller decrease in $\mathrm{BP}$ in overweight men and women with upper-range prehypertension or first-grade hypertension than ingestion of an $\mathrm{HC}$ diet on $\mathrm{d} 1$. However, this difference was not present after $4 \mathrm{wk}$ of treatment. The role of SNS activation in this adaptation needs 
further exploration using better techniques to measure (regional) sympathetic activation. These findings cannot explain the BP-lowering effect ascribed to dietary proteins.

\section{ACKNOWLEDGMENTS}

The authors thank Harrie Robins, Jeroen Smets, Sander Offermans, and Frank Engel for their work on the test days. They thank Yvette Jansen for analyzing the raw cardiac output data and Jos op ' $t$ Roodt for sharing his expertise on the different measurements and for analyzing the raw plethysmograph data.

TI Food and Nutrition, which supported this study, is a public private partnership of science, industry, and government that conducts strategic research in food and nutrition (http://www.tifn.nl).

The authors' responsibilities were as follows: M.A.v.B., E.J.B., J.M.G., P.W.d.L. and S.J.L.B.: designed the study; J.D., K.F.M.T-B., and M.A.v.B.: conducted the study; K.F.M.T-B., M.A.v.B. and J.S.: analyzed the data; K.F.M.T-B., M.A.v.B., J.D., E.J.B., J.M.G., P.W.d.L., J.S. and S.J.L.B.: wrote the manuscript; and M.A.v.B assumed primary responsibility for the final content. All authors read and approved the final version of the manuscript. 


\section{REFERENCES}

1. Burke V, Hodgson JM, Beilin LJ, Giangiulioi N, Rogers P, Puddey IB. Dietary protein and soluble fiber reduce ambulatory blood pressure in treated hypertensives. Hypertension. 2001;38(4):821-6.

2. Hodgson JM, Burke V, Beilin LJ, Puddey IB. Partial substitution of carbohydrate intake with protein intake from lean red meat lowers blood pressure in hypertensive persons. Am J Clin Nutr. 2006;83(4):780-7.

3. Brinkworth GD, Noakes M, Parker B, Foster P, Clifton PM. Long-term effects of advice to consume a high-protein, low-fat diet, rather than a conventional weight-loss diet, in obese adults with type 2 diabetes: one-year follow-up of a randomised trial. Diabetologia. 2004;47(10):1677-86.

4. Ferrara LA, Innelli P, Palmieri V, Limauro S, De Luca G, Ferrara F, et al. Effects of different dietary protein intakes on body composition and vascular reactivity. Eur J Clin Nutr. 2006;60(5):643-9.

5. Appel LJ, Sacks FM, Carey VJ, Obarzanek E, Swain JF, Miller ER, 3rd, et al. Effects of protein, monounsaturated fat, and carbohydrate intake on blood pressure and serum lipids: results of the OmniHeart randomized trial. Jama. 2005;294(19):2455-64.

6. Teunissen-Beekman KF, Dopheide J, Geleijnse JM, Bakker SJ, Brink EJ, de Leeuw PW, et al. Protein supplementation lowers blood pressure in overweight adults: effect of dietary proteins on blood pressure (PROPRES), a randomized trial. Am J Clin Nutr. 2012;95(4):966-71.

7. Masuo K, Rakugi H, Ogihara T, Esler MD, Lambert GW. Cardiovascular and renal complications of type 2 diabetes in obesity: role of sympathetic nerve activity and insulin resistance. Curr Diabetes Rev. 2010;6(2):58-67.

8. Scherrer U, Sartori C. Insulin as a vascular and sympathoexcitatory hormone: implications for blood pressure regulation, insulin sensitivity, and cardiovascular morbidity. Circulation. 1997;96(11):4104-13.

9. Ferreira-Filho SR, Ferreira AC, Oliveira PC, Moreira JF, Ribeiro EC, Oliveira AM, et al. Systemic hemodynamic changes in elderly hypertensive patients after ingesting foods with lipid, protein, and carbohydrate contents. Journal of clinical hypertension. 2009;11(5):271-6.

10. Ferreira-Filho SR, de Castro Rodrigues Ferreira AC, de Oliveira PC. Systemic hemodynamic changes in young and elderly normotensive individuals after ingestion of meals with high lipid, protein, and carbohydrate contents. Blood Press Monit. 2012;17(3):110-5.

11. Hoost $U$, Kelbaek $H$, Rasmusen $H$, Court-Payen $M$, Christensen NJ, Pedersen-Bjergaard $U$, et al. Haemodynamic effects of eating: the role of meal composition. Clin Sci (Lond). 1996;90(4):269-76.

12. Potter JF, Heseltine D, Hartley G, Matthews J, MacDonald IA, James OF. Effects of meal composition on the postprandial blood pressure, catecholamine and insulin changes in elderly subjects. Clin Sci (Lond). 1989;77(3):265-72.

13. Pal S, Ellis V. Acute effects of whey protein isolate on blood pressure, vascular function and inflammatory markers in overweight postmenopausal women. Br J Nutr. 2011;105(10):1512-9.

14. Evans S, Royston P, Day S. Minim: allocation by minimisation in clinical trials [Internet]. [updated 2004 Jun 29; cited 2012 Dec 13]. Available from: http://www-users.york.ac.uk/ mb55/guide/minim.htm.

15. Roza AM, Shizgal HM. The Harris Benedict equation reevaluated: resting energy requirements and the body cell mass. Am J Clin Nutr. 1984;40(1):168-82.

16. van der Hoorn FA, Boomsma F, Man in 't Veld AJ, Schalekamp MA. Determination of catecholamines in human plasma by high-performance liquid chromatography: comparison between a new method with fluorescence detection and an established method with electrochemical detection. J Chromatogr. 1989;487(1):17-28.

17. Azabji Kenfack M, Lador F, Licker M, Moia C, Tam E, Capelli C, et al. Cardiac output by Modelflow method from intra-arterial and fingertip pulse pressure profiles. Clin Sci (Lond). 2004;106(4):365-9.

18. Straznicky NE, Lambert GW, Masuo K, Dawood T, Eikelis N, Nestel PJ, et al. Blunted sympathetic neural response to oral glucose in obese subjects with the insulin-resistant metabolic syndrome. Am J Clin Nutr. 2009;89(1):27-36.

19. Young CN, Deo SH, Chaudhary K, Thyfault JP, Fadel PJ. Insulin enhances the gain of arterial baroreflex control of muscle sympathetic nerve activity in humans. The Journal of physiology. 2010;588(Pt 18):3593-603.

20. Grieve DJ, Cassidy RS, Green BD. Emerging cardiovascular actions of the incretin hormone glucagon-like peptide-1: potential therapeutic benefits beyond glycaemic control? Br J Pharmacol. 2009;157(8):134051. 
21. Bowen J, Noakes M, Clifton PM. Appetite hormones and energy intake in obese men after consumption of fructose, glucose and whey protein beverages. Int J Obes (Lond). 2007;31(11):1696-703.

22. May M, Jordan J. The osmopressor response to water drinking. Am J Physiol Regul Integr Comp Physiol. 2011;300(1):R40-6.

23. De Mey C, Enterling D, Meineke I. Cardiovascular effects of eating, atenolol and their interaction: beta1adrenergic modulation does not play a predominant role in the genesis of postprandial effects. $\mathrm{Br} \mathrm{J} C \mathrm{Clin}$ Pharmacol. 1993;36(5):427-35.

24. Harthoorn LF, Dransfield E. Periprandial changes of the sympathetic-parasympathetic balance related to perceived satiety in humans. Eur J Appl Physiol. 2008;102(5):601-8.

25. Scott EM, Greenwood JP, Vacca G, Stoker JB, Gilbey SG, Mary DA. Carbohydrate ingestion, with transient endogenous insulinaemia, produces both sympathetic activation and vasodilatation in normal humans. Clin Sci (Lond). 2002;102(5):523-9.

26. Cox HS, Kaye DM, Thompson JM, Turner AG, Jennings GL, Itsiopoulos C, et al. Regional sympathetic nervous activation after a large meal in humans. Clin Sci (Lond). 1995;89(2):145-54.

27. Vaz M, Turner A, Kingwell B, Chin J, Koff E, Cox H, et al. Postprandial sympatho-adrenal activity: its relation to metabolic and cardiovascular events and to changes in meal frequency. Clin Sci (Lond). 1995;89(4):349-57.

28. Fagius J, Berne C. Increase in muscle nerve sympathetic activity in humans after food intake. Clin Sci (Lond). 1994;86(2):159-67.

29. Fugmann A, Millgard J, Sarabi M, Berne C, Lind L. Central and peripheral haemodynamic effects of hyperglycaemia, hyperinsulinaemia, hyperlipidaemia or a mixed meal. Clinical science. 2003;105(6):71521.

30. Oberman AS, Gagnon MM, Kiely DK, Nelson JC, Lipsitz LA. Autonomic and neurohumoral control of postprandial blood pressure in healthy aging. J Gerontol A Biol Sci Med Sci. 2000;55(8):M477-83.

31. Masuo K, Mikami H, Ogihara T, Tuck ML. Mechanisms mediating postprandial blood pressure reduction in young and elderly subjects. Am J Hypertens. 1996;9(6):536-44.

32. Luciano GL, Brennan MJ, Rothberg MB. Postprandial hypotension. Am J Med. 2010;123(3):281 e1-6.

33. Penev $\mathrm{P}$, Spiegel K, Marcinkowski T, Van Cauter E. Impact of carbohydrate-rich meals on plasma epinephrine levels: dysregulation with aging. J Clin Endocrinol Metab. 2005;90(11):6198-206.

34. Grassi G, Esler M. How to assess sympathetic activity in humans. J Hypertens. 1999;17(6):719-34. 


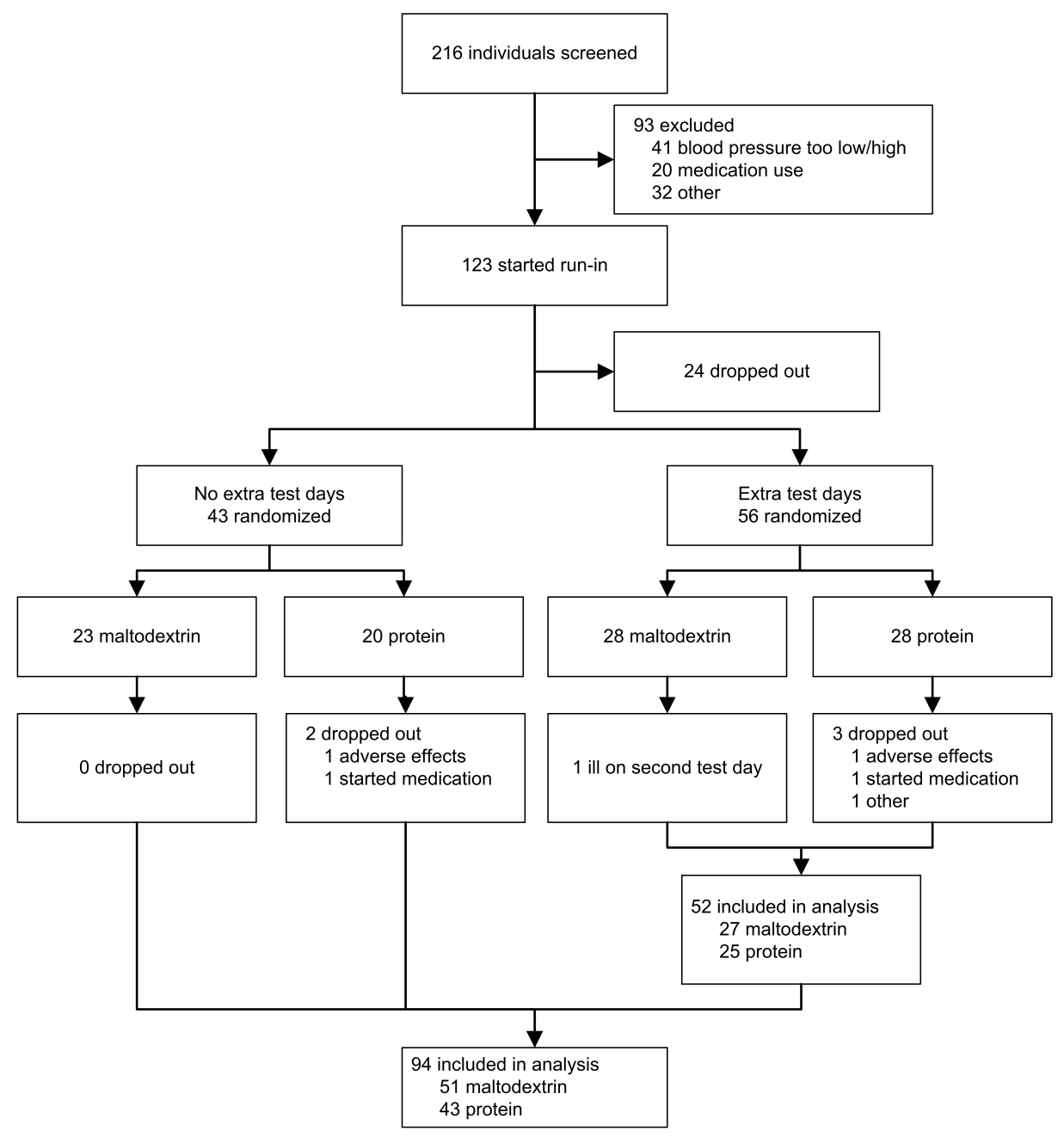

Supplemental Figure 1. Flow chart of PROPRES participants. The right branch shows the subgroup who participated in the extra tests on $\mathrm{d} 1$ and wk 4 . Randomized clinical trial on the effects of PROteins on blood PRESsure, PROPRES. 
Supplemental table 1. Meal composition during the tests on d 1 and wk 4. Example $2000 \mathrm{kcal} / \mathrm{d}$.

\begin{tabular}{|c|c|c|}
\hline & HP & $\mathrm{HC}$ \\
\hline \multicolumn{3}{|l|}{ Meal composition, energy\% } \\
\hline Carbohydrate & 40 & 55 \\
\hline Protein & 25 & 15 \\
\hline Fat & 30 & 30 \\
\hline \multicolumn{3}{|l|}{ Breakfast, lunch } \\
\hline Energy\% ${ }^{1}$ & 30 & 30 \\
\hline Protein supplement, g & 20 & 0 \\
\hline Maltodextrin supplement, g & 0 & 20 \\
\hline Water, mL & 200 & 200 \\
\hline Whole grain bread, g & 88 & 88 \\
\hline Low fat margarine, $\mathrm{g}$ & 20 & 20 \\
\hline Jam, g & 21 & 21 \\
\hline Cheese, g & 20 & 20 \\
\hline Apple, g & 150 & 150 \\
\hline Milk, g & 190 & 190 \\
\hline \multicolumn{3}{|l|}{ Dinner } \\
\hline Energy\% $^{1}$ & 40 & 40 \\
\hline Protein supplement, $\mathrm{g}$ & 20 & 0 \\
\hline Maltodextrin supplement, g & 0 & 20 \\
\hline Water, mL & 200 & 200 \\
\hline Macaroni meal (Albert Heijn), g & 425 & 425 \\
\hline Minced meat, g & 65 & 65 \\
\hline Sunflower oil, g & 0 & 0 \\
\hline Courgette, g & 60 & 60 \\
\hline Non-fat fruit yoghurt (Albert Heijn), g & 140 & 140 \\
\hline
\end{tabular}

${ }^{1} \%$ of daily energy need calculated with the revised Harris \& Benedict equation (15) multiplied by 1.3. High carbohydrate group, HC; high protein group, HP.

Supplemental table 2. Supplement composition per serving ${ }^{1}$

\begin{tabular}{lcc}
\hline & HP & HC \\
\hline Weight, $g$ & 24.9 & 24.1 \\
Energy, $k c a l$ & 89 & 84 \\
Protein, $g$ & 20.3 & 0.0 \\
Carbohydrate, $g$ & 0.3 & 20.1 \\
Fat, $g$ & 0.7 & 0.0 \\
Fiber, $g$ & 0.2 & 0.0 \\
Minerals & & \\
Sodium, $m g$ & 196 & 241 \\
Potassium, $m g$ & 103 & 139 \\
Calcium, $m g$ & 148 & 188 \\
Phosphate, $m g$ & 191 & 226 \\
Magnesium, $m g$ & 16 & 22 \\
\hline
\end{tabular}

${ }^{1}$ Supplements were dissolved in $200 \mathrm{~mL}$ water and consumed with each meal (3 times per d). High carbohydrate group, HC; high protein group, HP. 
Supplemental table 3. Differences in $12 \mathrm{~h}$ postprandial changes in SBP, DBP, MAP, CO, TPR, HR, SV, FBF, plasma NE, plasma E, plasma glucose, serum insulin, urine NE and urine $E$ after HC and HP meals on $\mathrm{d} 1$ (left) and after 4 wk (right) of supplementation. ${ }^{1}$

\begin{tabular}{|c|c|c|c|c|c|c|}
\hline & \multicolumn{3}{|c|}{ day 1} & \multicolumn{3}{|c|}{4 weeks } \\
\hline & $\begin{array}{c}\text { Estimate } \\
(95 \% \mathrm{Cl})\end{array}$ & $\begin{array}{c}\text { P- } \\
\text { value }\end{array}$ & $\begin{array}{c}n \\
\text { HC/HP } \\
\text { (miss) }^{2}\end{array}$ & $\begin{array}{c}\text { Estimate } \\
(95 \% \mathrm{Cl})\end{array}$ & $\begin{array}{c}\text { P- } \\
\text { value }\end{array}$ & $\begin{array}{c}n \\
\mathrm{HC} / \mathrm{HP} \\
(\mathrm{miss})^{2} \\
\end{array}$ \\
\hline \multirow{3}{*}{ Plasma NE, In } & & & $26 / 24$ & & & $27 / 24$ \\
\hline & & & $(12)$ & & & (4) \\
\hline & 0.03 & & & 0.01 & & \\
\hline \multirow[t]{2}{*}{ Group } & $(-0.1,0.1)$ & 0.62 & & $(-0.09,0.1)$ & 0.81 & \\
\hline & 0.005 & & & & & \\
\hline Age & $(-0.001,0.01)$ & 0.10 & & & & \\
\hline \multicolumn{7}{|l|}{ Gender $^{3}$} \\
\hline \multicolumn{7}{|l|}{ BMI } \\
\hline \multirow{3}{*}{ Group, $\%{ }^{4}$} & 3 & & & 1 & & \\
\hline & $(-8,15)$ & & & $(-9,12)$ & & \\
\hline & & & $26 / 24$ & & & $27 / 24$ \\
\hline \multirow[t]{2}{*}{ Plasma $\mathrm{E}$, In } & & & $(12)$ & & & (4) \\
\hline & -0.1 & & & -0.1 & & \\
\hline Group & $(-0.2,0.01)$ & 0.06 & & $(-0.2,0.1)$ & 0.33 & \\
\hline \multicolumn{7}{|l|}{ Age } \\
\hline \multicolumn{7}{|l|}{ Gender $^{3}$} \\
\hline \multirow{3}{*}{ BMI } & 0.03 & & & 0.02 & & \\
\hline & $(0.004,0.05)$ & 0.02 & & $(0.001,0.05)$ & 0.06 & \\
\hline & -11 & & & -6 & & \\
\hline \multirow[t]{2}{*}{ Group, $\%^{4}$} & $(-22,1)$ & & & $(-19,7)$ & & \\
\hline & & & $26 / 23$ & & & $24 / 25$ \\
\hline \multirow[t]{2}{*}{ Urine NE, $\mathrm{nmol}^{-4} \mathrm{~h}^{-1}$} & & & $(4)$ & & & (2) \\
\hline & -1.1 & & & 0.8 & & \\
\hline Group & $(-6.5,4.3)$ & 0.68 & & $(-5.2,6.8)$ & 0.79 & \\
\hline \multicolumn{7}{|l|}{ Age } \\
\hline \multirow{3}{*}{ Gender $^{3}$} & 13.5 & & & 7.6 & & \\
\hline & $(7.1,20.0)$ & $<0.001$ & & $(1.1,14.2)$ & 0.05 & \\
\hline & 1.2 & & & 1.5 & & \\
\hline \multirow[t]{2}{*}{ BMI } & $(0.3,2.2)$ & 0.02 & & $(0.4,2.6)$ & 0.01 & \\
\hline & & & $26 / 23$ & & & $24 / 25$ \\
\hline \multirow[t]{2}{*}{ Urine $\mathrm{E}, \mathrm{nmol} \cdot 4 \mathrm{~h}^{-1}$} & & & (4) & & & (2) \\
\hline & -0.9 & & & -0.3 & & \\
\hline \multirow[t]{2}{*}{ Group } & $(-1.8,0.1)$ & 0.09 & & $(-1.3,0.6)$ & 0.46 & \\
\hline & -0.1 & & & -0.05 & & \\
\hline \multirow[t]{2}{*}{ Age } & $(-0.1,-0.01)$ & 0.07 & & $(-0.1,-0.001)$ & 0.05 & \\
\hline & 1.4 & & & & & \\
\hline \multirow[t]{2}{*}{ Gender $^{3}$} & $(0.3,2.6)$ & 0.01 & & & & \\
\hline & 0.2 & & & & & \\
\hline BMI & $(-0.02,0.33)$ & 0.08 & & & & \\
\hline
\end{tabular}




\begin{tabular}{|c|c|c|c|c|c|c|}
\hline & \multicolumn{3}{|c|}{ day 1} & \multicolumn{3}{|c|}{4 weeks } \\
\hline & Estimate $(95 \% \mathrm{Cl})$ & $\begin{array}{c}\text { P- } \\
\text { value }\end{array}$ & $\begin{array}{c}n \\
\text { HC/HP } \\
(\text { miss) }\end{array}$ & $\begin{array}{c}\text { Estimate } \\
(95 \% \mathrm{Cl})\end{array}$ & $\begin{array}{c}\text { P- } \\
\text { value }\end{array}$ & $\begin{array}{c}n \\
\text { HC/HP } \\
\text { (miss) }^{2}\end{array}$ \\
\hline & & & $27 / 25$ & & & $27 / 25$ \\
\hline $\mathrm{SBP}, \mathrm{mmHg}$ & & & (2) & & & (1) \\
\hline & -3.6 & & & 0.5 & & \\
\hline Group & $(-6.8,-0.3)$ & 0.03 & & $(-2.8,3.8)$ & 0.75 & \\
\hline \multicolumn{7}{|l|}{ Age } \\
\hline & 4.9 & & & 5.2 & & \\
\hline Gender $^{3}$ & $(1.4,8.4)$ & 0.006 & & $(1.6,8.8)$ & 0.01 & \\
\hline \multicolumn{7}{|l|}{ BMI } \\
\hline & & & $27 / 25$ & & & $27 / 25$ \\
\hline \multirow[t]{2}{*}{$\mathrm{DBP}, \mathrm{mmHg}$} & & & $(2)$ & & & (1) \\
\hline & -3.6 & & & -2.0 & & \\
\hline \multirow[t]{2}{*}{ Group } & $(-6.2,-1.0)$ & 0.008 & & $(-4.2,0.2)$ & 0.07 & \\
\hline & -0.1 & & & & & \\
\hline Age & $(-0.3,-0.002)$ & 0.046 & & & & \\
\hline \multicolumn{7}{|l|}{ Gender $^{3}$} \\
\hline \multicolumn{7}{|l|}{ BMI } \\
\hline & & & $27 / 25$ & & & $27 / 25$ \\
\hline \multirow{2}{*}{$\mathrm{MAP}, \mathrm{mmHg}$} & & & (2) & & & (1) \\
\hline & -3.9 & & & -1.2 & & \\
\hline \multirow[t]{2}{*}{ Group } & $(-6.4,-1.5)$ & 0.002 & & $(-3.5,1.2)$ & 0.32 & \\
\hline & -0.2 & & & & & \\
\hline \multirow[t]{2}{*}{ Age } & $(-0.3,-0.03)$ & 0.08 & & & & \\
\hline & 3.3 & & & 2.5 & & \\
\hline Gender $^{3}$ & $(0.6,5.9)$ & 0.02 & & $(-0.03,4.9)$ & 0.05 & \\
\hline \multicolumn{7}{|l|}{ BMI } \\
\hline & & & $24 / 25$ & & & $27 / 25($ \\
\hline \multirow{2}{*}{$\mathrm{TPR}, m m H g \cdot \min \cdot L^{-1}$} & & & (3) & & & 5) \\
\hline & -1.1 & & & -1 & & \\
\hline Group & $(-2.3,-0.02)$ & 0.053 & & $(-2.0,0.1)$ & 0.07 & \\
\hline \multicolumn{7}{|l|}{ Age } \\
\hline & 1.1 & & & & & \\
\hline Gender $^{3}$ & $(-0.2,2.4)$ & 0.09 & & & & \\
\hline \multicolumn{7}{|l|}{ BMI } \\
\hline & & & $24 / 25$ & & & $27 / 25$ \\
\hline \multirow[t]{2}{*}{$\mathrm{CO}, L \cdot \min ^{-1}$} & & & (3) & & & (5) \\
\hline & 0.2 & & & 0.4 & & \\
\hline Group & $(-0.2,0.6)$ & 0.42 & & $(-0.05,0.79)$ & 0.08 & \\
\hline \multicolumn{7}{|l|}{ Age } \\
\hline \multicolumn{7}{|l|}{ Gender $^{3}$} \\
\hline & 0.07 & & & & & \\
\hline BMI & $(-0.01,0.2)$ & 0.08 & & & & \\
\hline
\end{tabular}


Online Supporting Material

Supplemental table 3 continued

\begin{tabular}{|c|c|c|c|c|c|c|}
\hline & \multicolumn{3}{|c|}{ day 1} & \multicolumn{3}{|c|}{4 weeks } \\
\hline & Estimate $(95 \% \mathrm{Cl})$ & $\begin{array}{c}\text { P- } \\
\text { value }\end{array}$ & $\begin{array}{c}n \\
\mathrm{HC} / \mathrm{HP} \\
\text { (miss) }^{2}\end{array}$ & $\begin{array}{c}\text { Estimate } \\
(95 \% \mathrm{Cl})\end{array}$ & $\begin{array}{c}\text { P- } \\
\text { value }\end{array}$ & $\begin{array}{c}n \\
\mathrm{HC} / \mathrm{HP} \\
\text { (miss) } \\
\end{array}$ \\
\hline & & & $27 / 24$ & & & $27 / 25$ \\
\hline $\mathrm{HR}$, beats $\cdot \mathrm{min}^{-1}$ & & & (2) & & & (1) \\
\hline & -0.2 & & & -0.03 & & \\
\hline Group & $(-2.3,1.8)$ & 0.81 & & $(-1.8,1.7)$ & 0.97 & \\
\hline \multicolumn{7}{|l|}{ Age } \\
\hline & -4.1 & & & -3 & & \\
\hline \multirow[t]{2}{*}{ Gender $^{3}$} & $(-6.5,-1.8)$ & $<0.001$ & & $(-5.0,-1.0)$ & 0.01 & \\
\hline & & & & 0.4 & & \\
\hline \multirow[t]{2}{*}{ BMI } & & & & $(0.1,0.7)$ & 0.01 & \\
\hline & & & $24 / 24$ & & & $27 / 25$ \\
\hline \multirow[t]{2}{*}{$\mathrm{SV}, m L$} & & & (3) & & & (5) \\
\hline & 2 & & & 3 & & \\
\hline Group & $(-4,9)$ & 0.5 & & $(-4,10)$ & 0.45 & \\
\hline \multicolumn{7}{|l|}{ Age } \\
\hline & & & & 11 & & \\
\hline Gender $^{3}$ & & & & $(3,2)$ & 0.01 & \\
\hline \multicolumn{7}{|l|}{$\mathrm{BMI}$} \\
\hline & & & $25 / 25$ & & & $27 / 23$ \\
\hline $\mathrm{FBF}, \ln$ & & & (9) & & & (11) \\
\hline & 0.02 & & & -0.1 & & \\
\hline Group & $(-0.1,0.1)$ & 0.75 & & $(-0.2,0.03)$ & 0.15 & \\
\hline \multicolumn{7}{|l|}{ Age } \\
\hline \multicolumn{7}{|l|}{ Gender $^{3}$} \\
\hline \multirow{3}{*}{ BMI } & -0.02 & & & & & \\
\hline & $(-0.04,0.002)$ & 0.07 & & & & \\
\hline & 2 & & & -9 & & \\
\hline Group, $\%^{4}$ & $(-10,15)$ & & & $(-19,3)$ & & \\
\hline \multirow[t]{2}{*}{$\begin{array}{l}\text { Plasma glucose, } \\
\mathrm{mmol} \cdot \mathrm{L}^{-1}\end{array}$} & & & $\begin{array}{c}26 / 25 \\
(9)\end{array}$ & & & $\begin{array}{c}27 / 24 \\
(5)\end{array}$ \\
\hline & 0.5 & & & 0.5 & & \\
\hline Group & $(0.2,0.8)$ & $<0.001$ & & $(0.2,0.9)$ & 0.002 & \\
\hline \multicolumn{7}{|l|}{ Age } \\
\hline \multicolumn{7}{|l|}{ Gender $^{3}$} \\
\hline BMI & & & & & & \\
\hline
\end{tabular}




\begin{tabular}{|c|c|c|c|c|c|c|}
\hline & \multicolumn{3}{|c|}{ day 1} & \multicolumn{3}{|c|}{4 weeks } \\
\hline & Estimate $(95 \% \mathrm{Cl})$ & $\begin{array}{c}\text { P- } \\
\text { value }\end{array}$ & $\begin{array}{c}n \\
\mathrm{HC} / \mathrm{HP} \\
\text { (miss) }^{2}\end{array}$ & $\begin{array}{l}\text { Estimate } \\
(95 \% \mathrm{CI})\end{array}$ & $\begin{array}{c}\mathrm{P} \text { - } \\
\text { value }\end{array}$ & $\begin{array}{c}n \\
\text { HC/HP } \\
\text { (miss) }^{2} \\
\end{array}$ \\
\hline Serum insulin, In & & & $\begin{array}{c}26 / 25 \\
(10)\end{array}$ & & & $\begin{array}{c}27 / 25 \\
(5)\end{array}$ \\
\hline Group & $0.2(0.1,0.3)$ & $<0.001$ & & $0.2(0.1,0.4)$ & 0.006 & \\
\hline \multicolumn{7}{|l|}{ Age } \\
\hline \multicolumn{7}{|l|}{ Gender $^{3}$} \\
\hline BMI & & & & $\begin{array}{c}0.03(-0.001 \\
0.1)\end{array}$ & 0.05 & \\
\hline Group, $\%^{4}$ & $24(10,41)$ & & & $24(7,44)$ & & \\
\hline
\end{tabular}

${ }^{1}$ Differences between groups (HC - HP) on $\mathrm{d} 1$ and after $4 \mathrm{wk}$ based on the mixed model analyses.

${ }^{2} \mathrm{n} \mathrm{HC} / \mathrm{HP}$ (miss): number of participants of the HC and HP group in the analyses. Miss is the number of persons included in the analyses who miss more than $20 \%$ of the measurements.

${ }^{3}$ Gender: $\mathrm{M}=1, \mathrm{~F}=0$

${ }^{4}$ Group\%: the difference between groups is also displayed in $\%$ for In data, to help interpretation of between-group differences in In variables.

Serum insulin is expressed in $\mathrm{mU} \cdot \mathrm{L}^{-1}$. Values can be converted to $\mathrm{pmol} \cdot \mathrm{L}^{-1}$ by multiplying by 6.945 .

CO, Cardiac output; DBP, diastolic blood pressure; FBF, forearm blood flow; E, plasma epinephrine; HC, high carbohydrate group; HP, high protein group; HR, heart rate; MAP, mean arterial pressure; NE, plasma norepinephrine; SBP, systolic blood pressure; SV, stroke volume; TPR, total peripheral resistance. 



\title{
Chapter 5
}

\section{Differential effects of proteins and carbohydrates on postprandial blood pressure- related responses}

\author{
Br J Nutr. 2014, 112: 600-8
}

Karianna F.M. Teunissen-Beekman

Janneke Dopheide Johanna M. Geleijnse Stephan J.L. Bakker Elizabeth J. Brink Peter W. de Leeuw Jan Serroyen Marleen A. van Baak 


\section{ABSTRACT}

Diet composition may affect blood pressure (BP), but the mechanisms are unclear. The aim of the present study was to compare postprandial BP-related responses to the ingestion of pea protein, milk protein and egg-white protein. In addition, postprandial BPrelated responses to the ingestion of maltodextrin were compared with those to the ingestion of sucrose and a protein mix. We hypothesised that lower postprandial total peripheral resistance (TPR) and BP levels would be accompanied by higher plasma concentrations of nitric oxide, insulin, glucagon-like peptide 1 (GLP-1) and glucagon. On separate occasions, six meals were tested in a randomised order in forty-eight overweight or obese adults with untreated elevated BP. Postprandial responses of TPR, BP and plasma concentrations of insulin, glucagon, GLP-1 and nitrite, nitroso compounds (RXNO) and Snitrosothiols (NOx) were measured for $4 \mathrm{~h}$. No differences were observed in TPR responses. Postprandial BP levels were higher after the ingestion of the egg-white-protein meal than after that of meals containing the other two proteins $(P \leq 0.01)$. The ingestion of the pea-protein meal induced the highest NOx response $(P \leq 0.006)$. Insulin and glucagon concentrations were lowest after the ingestion of the egg-white-protein meal $(P$ $\leq 0.009$ ). Postprandial BP levels were lower after the ingestion of the maltodextrin meal than after that of the protein mix and sucrose meals $(P \leq 0.004)$, while postprandial insulin concentrations were higher after the ingestion of the maltodextrin meal than after that of the sucrose and protein mix meals after $1-2 h(P \leq 0.0001)$. Postprandial NOx, GLP-1 and glucagon concentrations were lower after the ingestion of the maltodextrin meal than after that of the protein mix meal $(P \leq 0.008)$. In conclusion, different protein and carbohydrate sources induce different postprandial BP-related responses, which may be important for BP management. Lower postprandial BP levels are not necessarily accompanied by higher NOx, insulin, glucagon or GLP-1 responses. 


\section{INTRODUCTION}

The effect of dietary proteins on blood pressure (BP) has been evaluated in two recent meta-analyses, which concluded that replacement of part of dietary carbohydrates with proteins is beneficial in BP management $(1,2)$. It is still unclear whether different dietary proteins have different effects on BP (3). Randomised trials comparing the effects of prolonged intake of different types of proteins or different amino acids on BP are scarce. Mainly soya and milk proteins have been studied in this context, and a recent metaanalysis has shown that soya and milk proteins decrease BP to a similar extent (4). The postprandial BP responses to the ingestion of the milk proteins casein and whey have been found to be similar to those to the ingestion of a carbohydrate control (5). In a randomised clinical trial on the effects of PROteins on blood PRESsure (PROPRES), we found that the consumption of $60 \mathrm{~g} / \mathrm{d}$ of a protein mix for 4 weeks lowered BP compared with that of $60 \mathrm{~g} / \mathrm{d}$ of maltodextrin (6). Additional research in a subgroup of the PROPRES study has shown that the acute BP responses to the ingestion of mixed meals supplemented with the protein mix or maltodextrin differed. We found a smaller postprandial decrease in BP after the ingestion of a protein-supplemented meal than after that of a maltodextrin-supplemented meal, and we suggested that differences in insulin responses might explain these differences in the postprandial BP responses (7). From this study, it remained unclear whether the differences in BP responses after carbohydrate and protein intake can be generalised to ingestion of any kind of proteins and carbohydrates or are dependent on the type of protein or carbohydrate ingested. The aim of the present study was to investigate postprandial BP responses to the ingestion of proteins and carbohydrates from different sources. An additional objective was to explore the mechanisms via which different dietary factors affect BP. Postprandial responses are of interest because in clinical practice BP is often measured in the postprandial state and may therefore be influenced by prior meal ingestion. Moreover, prognostic epidemiological data are usually based on BP measurements taken during daily clinical practice, which are mostly not recorded in the fasted state. We hypothesised that lower postprandial total peripheral resistance (TPR) and BP levels would be accompanied by higher postprandial concentrations of plasma nitric oxide (NO). NO is a potent vasodilator produced in the vascular endothelium. Several hormones, such as insulin and glucagonlike peptide-1 (GLP-1), and amino acids, such as arginine, may increase endothelial NO release (8-10). The concentrations of these hormones and amino acids may be affected by protein ingestion (11-14). Therefore, our second hypothesis was that higher postprandial NO concentrations would be accompanied by higher concentrations of insulin, GLP-1 and/or glucagon. Glucagon has been hypothesised to increase NO production because of its vasodilatory effects; however, these effects can differ between vascular beds (15) and 
the effects of glucagon on NO release may be dependent on the condition studied (16, 17). In the present study, the postprandial effects of pea, milk and egg-white protein isolates were compared. These proteins were selected because they were included in the protein mix that lowered BP in the PROPRES study (6). In addition, we investigated whether the choice of our carbohydrate control in the PROPRES study(6) could have influenced our previous findings. Most studies on the BP-lowering effect of proteins have compared the effects of dietary proteins with those of carbohydrates (18). However, BP may respond differently after the consumption of different carbohydrate sources (19). Therefore, we chose to compare the postprandial effects of maltodextrin with those of sucrose, a widely consumed carbohydrate (table sugar) with a less pronounced insulin response compared with maltodextrin. We hypothesised that TPR and BP would decrease more after the consumption of maltodextrin than after that of sucrose due to a greater insulin response. Responses to the ingestion of maltodextrin were also compared with those to the ingestion of the protein mix tested in the PROPRES study (6).

\section{SUBJECTS AND METHODS}

\section{Subjects}

Subjects were recruited through local newspapers and via our database of subjects of the PROPRES study (6). Inclusion and exclusion criteria for the determination of subject eligibility were similar to those of the PROPRES study (6). The present study was conducted according to the guidelines laid down in the Declaration of Helsinki, and all procedures involving human subjects were approved by the medical ethics committee of Maastricht University Medical Center and Maastricht University (METC azM/UM). Written informed consent was obtained from all the subjects. The study was conducted at Maastricht University (Netherlands) between January and December 2011.

\section{Study diets and design}

The present study was a double-blind six-arm randomised cross-over trial. If eligible, the subjects were enrolled for a run-in period of 2 weeks, during which they followed a standard dietary advice as described previously (6). If their BP still met the inclusion criteria after the 2-week run-in period, the subjects were randomised to one of the six treatment orders using a computer program (MINIM; Stephen Evans, Simon Day and Patrick Royston; http://www-users.york.ac.uk/ mb55/guide/minim.htm). The subjects followed the dietary advice until the end of the study. This trial was registered at http://www.trialregister.nl: as NTR2678.

Test meals were six different powders containing either a protein or a carbohydrate mixed with $\mathrm{H}_{2} \mathrm{O}$ at a ratio of 1:4 and were consumed on six separate test days with a washout 
Table 1. Meal compositions for $70 \mathrm{~g}$ of protein or carbohydrate

\begin{tabular}{|c|c|c|c|c|c|c|}
\hline & $\begin{array}{c}\text { Milk } \\
\text { protein }\end{array}$ & $\begin{array}{l}\text { Egg-white } \\
\text { protein }\end{array}$ & $\begin{array}{c}\text { Pea } \\
\text { protein }\end{array}$ & Protein mix & $\begin{array}{l}\text { Malto- } \\
\text { dextrin }\end{array}$ & sucrose \\
\hline kJ & 1481 & 1443 & 1506 & 1460 & 1439 & 1460 \\
\hline Protein (g) & 70 & 70 & 70 & 70 & 0.37 & 0.36 \\
\hline Carbohydrates (g) & 2.8 & 2.6 & 2.1 & 1.7 & 70 & 70 \\
\hline Fat (g) & 7 & 6 & 8 & 6.9 & 7 & 7.5 \\
\hline Fiber (g) & 0.9 & 3.7 & 1.6 & 1.9 & 3.6 & 1.6 \\
\hline \multicolumn{7}{|l|}{ Minerals (mg) } \\
\hline Sodium & 940 & 980 & 1010 & 1060 & 1050 & 910 \\
\hline Potassium & 830 & 700 & 940 & 830 & 710 & 820 \\
\hline Calcium & 1170 & 1060 & 1160 & 1160 & 1120 & 1110 \\
\hline Phosphorous & 900 & 820 & 920 & 910 & 910 & 860 \\
\hline Magnesium & 66 & 67 & 73 & 71 & 69 & 62 \\
\hline
\end{tabular}

period of 1 week between each test. The test meals consisted of $0.6 \mathrm{~g}$ of protein or carbohydrate per kg body mass. Protein products tested were a pea protein isolate (Roquette), a milk protein isolate (DMV International), an egg-white protein isolate (Noventum Foods), and a mix of protein isolates consisting of $20 \%$ pea protein, $20 \%$ soya protein (ADM Specialty Food Ingredients), 30\% milk protein and 30\% egg-white protein. Carbohydrate products tested were maltodextrin (Syral) and sucrose (Suiker Unie). All the test products were of food grade. The test powders were matched for fat and mineral content (table 1 ) and mixed by NIZO food research. The amino acid compositions of the protein isolates are given in table 2 . The researchers and subjects were blinded to the meals. On the day before each test day, all the subjects consumed the same foods, which were provided by the researchers (15\% energy from protein, 30\% energy from fat and $55 \%$ energy from carbohydrate). On the test day, the subjects arrived at the university at 08.00 hours after an overnight fast. The test meals were consumed at T0. Measurements were taken at time points $-1 \mathrm{~h},+1 \mathrm{~h},+2 \mathrm{~h},+3 \mathrm{~h}$ and $+4 \mathrm{~h}$.

\section{Measurements}

During the screening visit and run-in period, BP and heart rate (HR) measurements were taken as described previously (6) On the test day, systolic blood pressure (SBP), diastolic blood pressure (DBP), mean arterial pressure (MAP) and HR were measured using a Spacelabs 90207 (Spacelabs Healthcare Limited), a validated automated BP monitor (20), with the subjects sitting on a bed in a semi-supine position. Cardiac output (CO) and stroke volume were measured non-invasively using the Finometer MIDI and BeatScope Easy software (Finapres Medical Systems) (21). TPR was calculated from the MAP and CO as described previously (7). Pulse pressure (PP) was calculated as follows: SBP-DBP. The central augmented pressure:pulse height ratio (augmentation index (Alx)), was derived from pulse wave analysis at the arteria radialis using the SphygmoCor CP system (Atcor 
Table 2. Amino acid compositions $(\mathrm{g} / 100 \mathrm{~g})$ of the protein sources.

\begin{tabular}{lccc}
\hline & Milk protein & Egg white protein & Pea protein \\
\hline Ala & 2.9 & 4.3 & 4.2 \\
Arg & 3.7 & 6 & 8.7 \\
Asp & 6.7 & 9.6 & 11.5 \\
Cys & 0.6 & 3 & 1.1 \\
Glu & 19.5 & 17 & 17.2 \\
Gly & 1.6 & 3.2 & 4.2 \\
His & 2.5 & 2.5 & 2.5 \\
Ile & 4.7 & 4.9 & 4.8 \\
Leu & 8.8 & 8.4 & 8.3 \\
Lys & 7.5 & 6.8 & 7.3 \\
Met & 2.6 & 2.3 & 1 \\
Phe & 4.4 & 5.1 & 5.3 \\
Pro & 9.7 & 6 & 4.5 \\
Ser & 5.1 & 5.6 & 5.1 \\
Thr & 3.9 & 4 & 4 \\
Trp & 1.1 & 1.2 & 1 \\
Tyr & 5 & 4.2 & 3.8 \\
Val & 6.3 & 5.8 & 5 \\
\hline
\end{tabular}

Medical) and corrected for a HR of 75 beats/min. Pulse wave velocity (PWV) was measured using the Vicorder (Skidmore Medical Limited). PWV measurements were taken with one loose cuff around the neck monitoring pulse waves in the arteria carotis and another cuff around the upper leg monitoring pulse waves in the arteria femoralis. PWV was assessed by recording the distance between the sternal notch and the middle of the leg cuff and dividing this by the time lag between the pulses from the carotis and femoralis. PWV was measured three times, and the average was used in analyses.

\section{Serum and plasma analyses}

Blood samples were collected in tubes containing heparin and lithium for the determination of nitrite, nitroso compounds (RXNO) and S-nitrosothiols (NOx). The samples in the tubes were centrifuged within $10 \mathrm{~min}$ after collection for $17 \mathrm{~min}$ at $4^{\circ} \mathrm{C}$ and $87 \mathrm{~g}$. Plasma was collected and stored at $-80^{\circ} \mathrm{C}$ until analysis. The concentrations of NOx were determined using a previously described chemiluminescence technique of Rikilt (22). The concentrations of plasma glucose, GLP-1, glucagon, angiotensin-converting enzyme (ACE) and serum insulin were measured by MLM Medical Labs. The concentrations of plasma glucose and serum insulin were determined as described previously (7). Blood samples were collected in EDTA collection tubes containing a dipeptidyl peptidase-IV inhibitor for GLP-1 analysis. The concentrations of active GLP-1 were measured with an ELISA (Linco Research). Blood samples were collected in EDTA tubes containing aprotinin for glucagon analysis. The concentrations of glucagon were determined using a RIA (Euro74 Chapter 5 
Diagnostic). The activity of ACE was also measured, because dietary proteins can affect BP via the inhibition of ACE (23). The activity of ACE was determined using the ACE-colour method (Fujirebio).

\section{Statistical analyses}

Baseline characteristics are reported as means with their standard errors. Changes in weight between week 3 (end of the run-in period) and week 8 were tested using a paired $t$ test. Postprandial responses were analysed with a linear mixed model approach to take the cross-over design and the correlation between repeated measures into account. The basic model consisted of a random intercept at the individual level. If significant, this model was extended with a random intercept at the meal within the individual level (individual*meal) or with a serial correlation over time. The basic model always included the following variables: time, meal, baseline measurements, and two variables controlling for the cross-over design: meal order and test day number. The interaction term between meal and time (meal*time) and the covariates age, sex and BMI were included in the model if $P \leq 0.05$. In case of a significant meal*time or meal effect, five post hoc comparisons were made, i.e. maltodextrin v. sucrose, maltodextrin v. protein mix, pea protein v. milk protein, pea protein v. egg-white protein, and milk protein v. egg-white protein. The critical $P$ value was corrected for these comparisons; therefore, post hoc differences were considered significant at $P \leq 0.01$. To determine whether postprandial changes from baseline were significant, the incremental AUC (iAUC) was tested for a significant difference from zero for each meal. This was done using a one-sample t-test and a critical $P$ value corrected for the six meals $(P=0.0083)$. All the analyses were carried out using SPSS software (version 19; IBM). The present study was powered to show a significant difference in TPR of at least $1 \mathrm{mmHg} / \mathrm{L}$ per min with a SD of $2.2 \mathrm{mmHg} / \mathrm{L}$ per min with a power of 0.8 . Based on these values forty participants would be needed. The aim was to include fifty participants, accounting for a dropout rate of $20 \%$.

\section{RESULTS}

\section{Subjects}

A total of forty-eight subjects were included in the present study (table 3 ). The subjects lost an average of 0.4 (SEM 0.2) kg of body mass during the six test weeks $(P=0.009)$. The carbohydrate test meals were well tolerated, but some subjects had trouble with fully finishing the protein meals. Of these subjects, three were unable to finish the pea-protein meal, three were unable to finish the milk-protein meal, one subject did not finish the egg-white-protein meal and one subject did not finish the protein mix meal completely.Because most of the meal was still consumed in these cases, data obtained 
Table 3. Baseline characteristics of the study participants (mean values \pm SEM)

\begin{tabular}{lc}
\hline & Mean \\
\hline Sex $(\mathrm{n})$ & 31 \\
Male & 17 \\
Female & $58 \pm 1$ \\
Age (years) & $28.6 \pm 0.3$ \\
BMI (kg/m ${ }^{2}$ ) & $5.5 \pm 0.1$ \\
Fasting plasma glucose $(\mathrm{mmol} / \mathrm{L})$ & $99 \pm 3$ \\
eGFR $\left(\mathrm{mL} \cdot \mathrm{min}^{-1} \cdot\left(1.73 \mathrm{~m}^{2}\right)^{-1}\right)$ & $144 \pm 1$ \\
SBP during run-in $(\mathrm{mmHg})$ & $92 \pm 1$ \\
DBP during run-in $(\mathrm{mmHg})$ &
\end{tabular}

DBP, diastolic blood pressure; eGFR, estimated glomerular filtration rate; SBP, systolic blood pressure.

${ }^{*}$ Estimated by the modification of diet in renal disease formula.

from these subjects were included in all the analyses.

\section{Postprandial responses}

Overall, significant time*meal interactions were found for SBP, DBP, MAP, HR, Alx, NOx, glucose, insulin, GLP-1 and glucagon responses after the ingestion of the six meals $(P \leq$ 0.03). PP responses to the ingestion of the six meals differed significantly, independent of time $(P=0.007)$. Details on how responses to the ingestion of the six meals differed are discussed below. TPR, CO, stroke volume, PWV and ACE responses to the ingestion of the six meals did not differ significantly.

\section{Responses to the ingestion of egg-white, milk and pea proteins}

The ingestion of the egg-white-protein meal resulted in a significant increase in SBP, MAP and $P P$, while that of the pea-protein meal significantly reduced DBP (iAUC, $P \leq 0.001$ ). At 2-4h, MAP was significantly higher after the ingestion of the egg-white-protein meal than after that of meals containing the other two proteins $(P \leq 0.01)$. SBP and DBP were also significantly higher after the ingestion of the egg-white-protein meal than after that of meals containing the other two proteins at most time points $(P \leq 0.008$, fig. 1 (a)-(c)). PP was significantly higher after the ingestion of the egg-white-protein meal than after that of the milk-protein meal, independent of time $(P=0.009$, data not shown). The ingestion of the pea-protein meal significantly decreased TPR and increased HR, while only the ingestion of the milk-protein meal significantly increased CO (iAUC, $P \leq 0.005$; fig. 1 (d)-(f)). Postprandial HR was significantly higher after the ingestion of the pea-protein meal than after that of the egg-white-protein meal between 1 and $3 \mathrm{~h}(P \leq 0.008$, fig. $1(\mathrm{~d}))$. The ingestion of all the three protein meals resulted in a decrease in the Alx (iAUC, $P \leq 0.001$ ). The Alx was significantly higher after the ingestion of the egg-white-protein meal than 


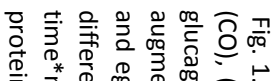

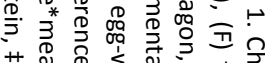

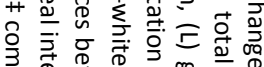

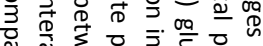

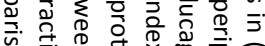

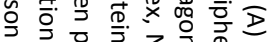

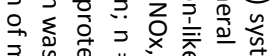

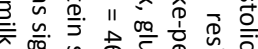

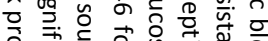

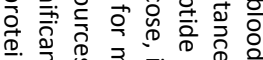

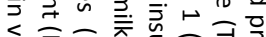

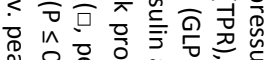
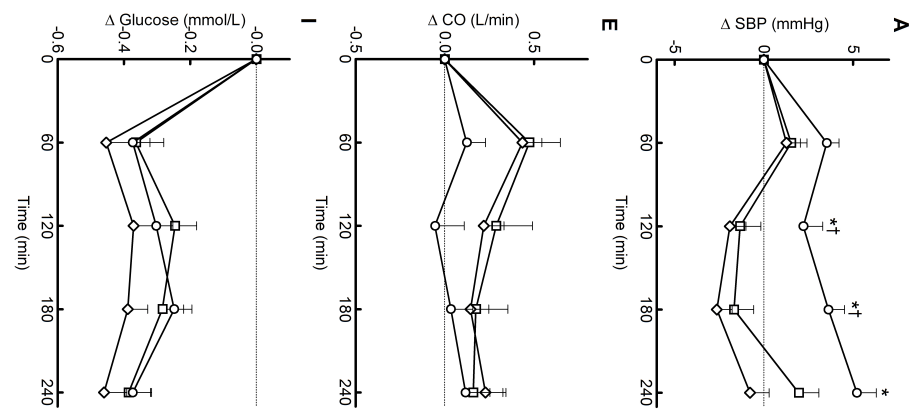

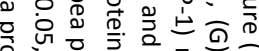

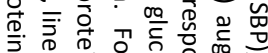

品 旁 옹

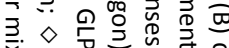

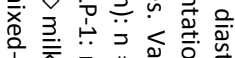

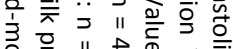

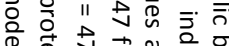

兽苦.

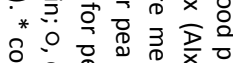

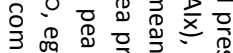

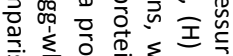

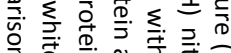
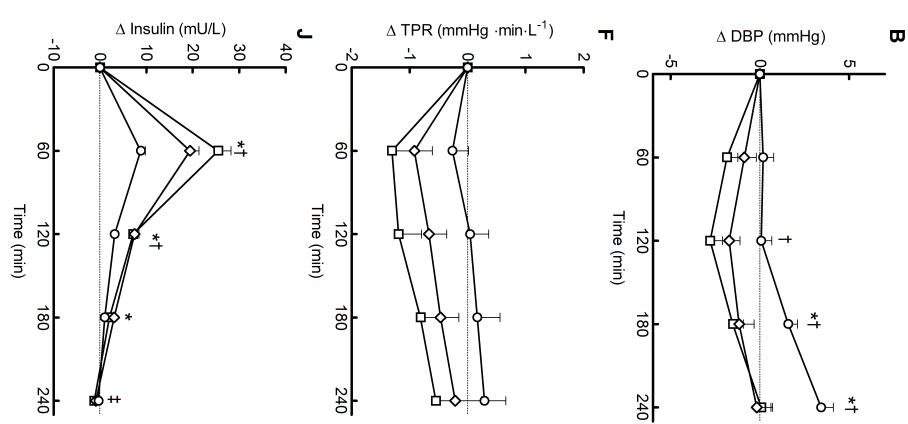

앙후의

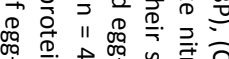

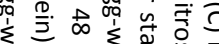

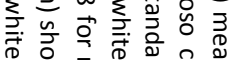

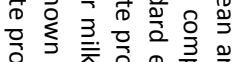

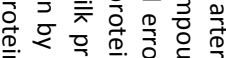

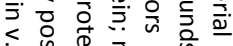

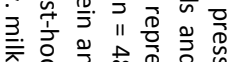

玄 욱

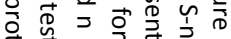

它.

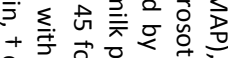

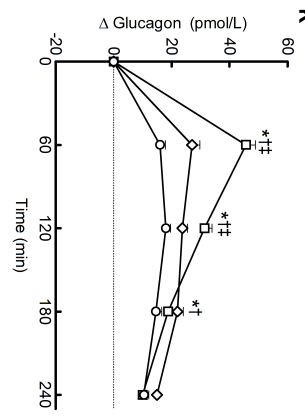

ᄌ $\Delta$ Augmentation index $(\%)$

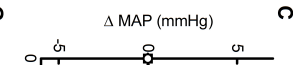

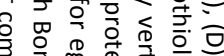

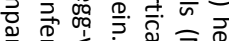

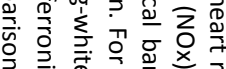

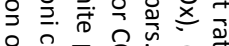

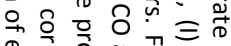

学

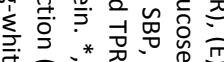

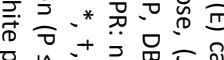

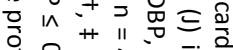

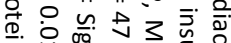

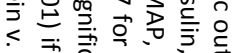
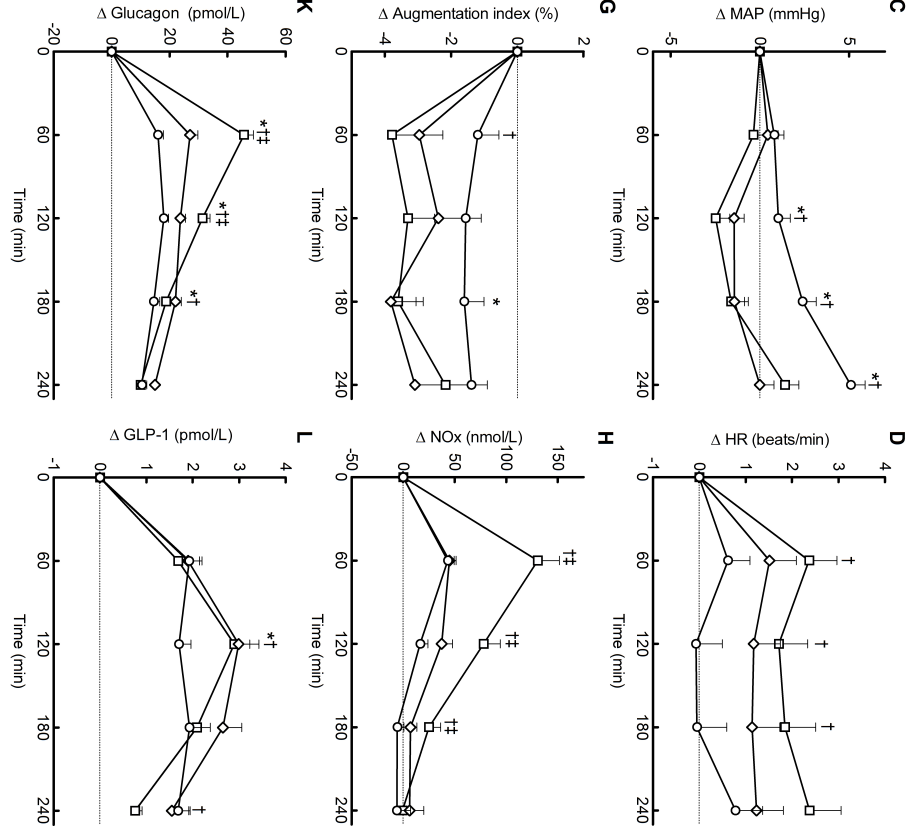

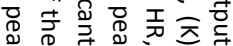


after that of the pea-protein meal at $1 \mathrm{~h}$ and higher than that after the ingestion of the milk-protein meal at $3 \mathrm{~h}(P \leq 0.002$, fig. $1(\mathrm{~g}))$. Plasma NOx concentrations were significantly increased after the ingestion of the pea- and milk-protein meals (iAUC, $P \leq 0.0001$ ). NOx concentrations were significantly higher after the ingestion of the pea-protein meal than after that of meals containing the other two proteins at $1-3 \mathrm{~h}(P \leq 0.006, \mathrm{fig} .1(\mathrm{~h}))$. The ingestion of all the three protein meals significantly reduced plasma glucose concentrations and increased insulin concentrations (IAUC, $P \leq 0.0001$, fig. $1(\mathrm{i})$ and (j)). No differences were observed in the postprandial plasma glucose responses to the ingestion of all the three protein meals (fig. 1(i)). Serum insulin concentrations were significantly lower at 1-3h after the ingestion of the egg-white-protein meal than after that of the milk-protein meal and at 1-2h compared with those after the ingestion of the pea-protein meal $(P \leq 0.0001)$. Serum insulin concentrations were significantly higher after the ingestion of the milk-protein meal than after that of the pea-protein meal after $4 \mathrm{~h}(P=$ 0.009 , fig. $1(\mathrm{j}))$. Postprandial plasma glucagon concentrations were increased after the ingestion of all the three protein meals (iAUC, $P \leq 0.0001$, fig. $1(\mathrm{k})$ ), but remained lowest after the ingestion of the egg-white-protein meal than after that of meals containing the other two proteins at $1-3 \mathrm{~h}(P \leq 0.009)$. At $1-2 \mathrm{~h}$ plasma glucagon concentrations observed after the ingestion of the pea-protein meal also differed significantly from those observed after the ingestion of the milk-protein meal, with the highest plasma glucagon concentrations being detected after the ingestion of the pea-protein meal $(P \leq 0.003$, fig. $1(k)$ ). Plasma GLP-1 concentrations were increased after the ingestion of all the three protein meals (iAUC, $P \leq 0.0001$, figure $1(I)$ ), but were significantly lower after the ingestion of the egg-white-protein meal than after that of meals containing the other two proteins after $2 \mathrm{~h}(P \leq 0.0001)$, while being higher after the ingestion of the egg-whiteprotein meal than after that of the pea-protein meal after $4 \mathrm{~h}(P=0.002$, fig. $1(\mathrm{I}))$. Plasma ACE activity was significantly decreased after the ingestion of the pea-protein meal (iAUC, $P=0.005$, data not shown); however, no differences were observed in the plasma ACE activity responses to the ingestion of the three protein meals.

Responses to the ingestion of maltodextrin compared with those to the ingestion of the protein mix and sucrose

DBP and MAP were significantly decreased after the ingestion of the maltodextrin meal (iAUC, $P \leq 0.0004$ ), but not after that of the protein mix or sucrose meal. SBP was not significantly increased or decreased after the ingestion of any of the three meals. PP was significantly increased after the ingestion of the protein mix meal (iAUC, $P=0.0001$, data not shown). SBP, DBP and MAP were significantly lower at $1 \mathrm{~h}$ after the ingestion of the maltodextrin meal than after that of the sucrose and protein mix meals ( $P \leq 0.003)$. DBP 


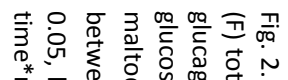

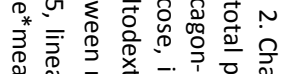

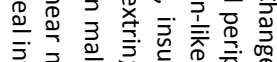

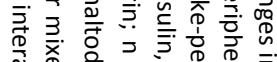

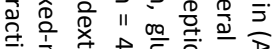

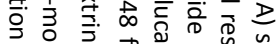

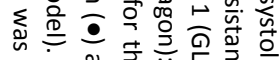

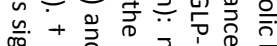

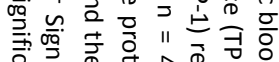

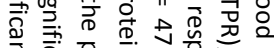

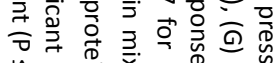

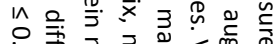

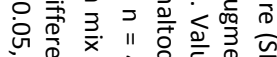

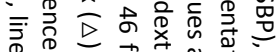

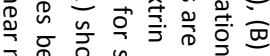

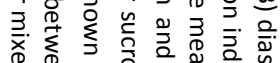

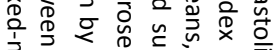

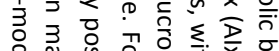

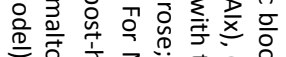

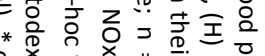

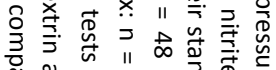

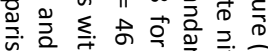

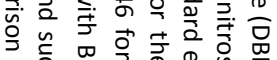

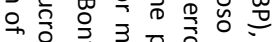

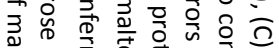

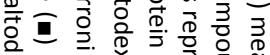

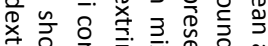

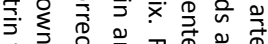

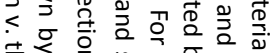

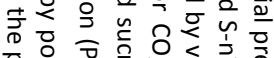

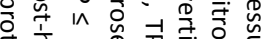

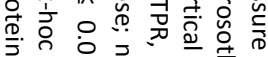
उ. $\overrightarrow{0}$ 过

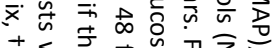

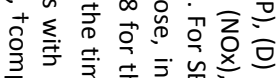

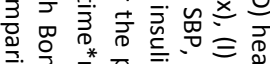

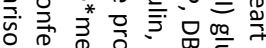

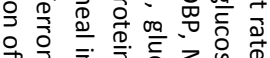

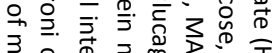

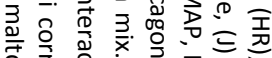

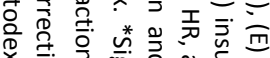

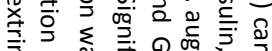

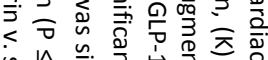

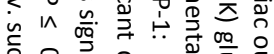

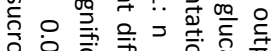

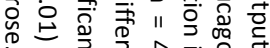

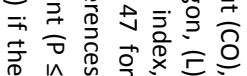
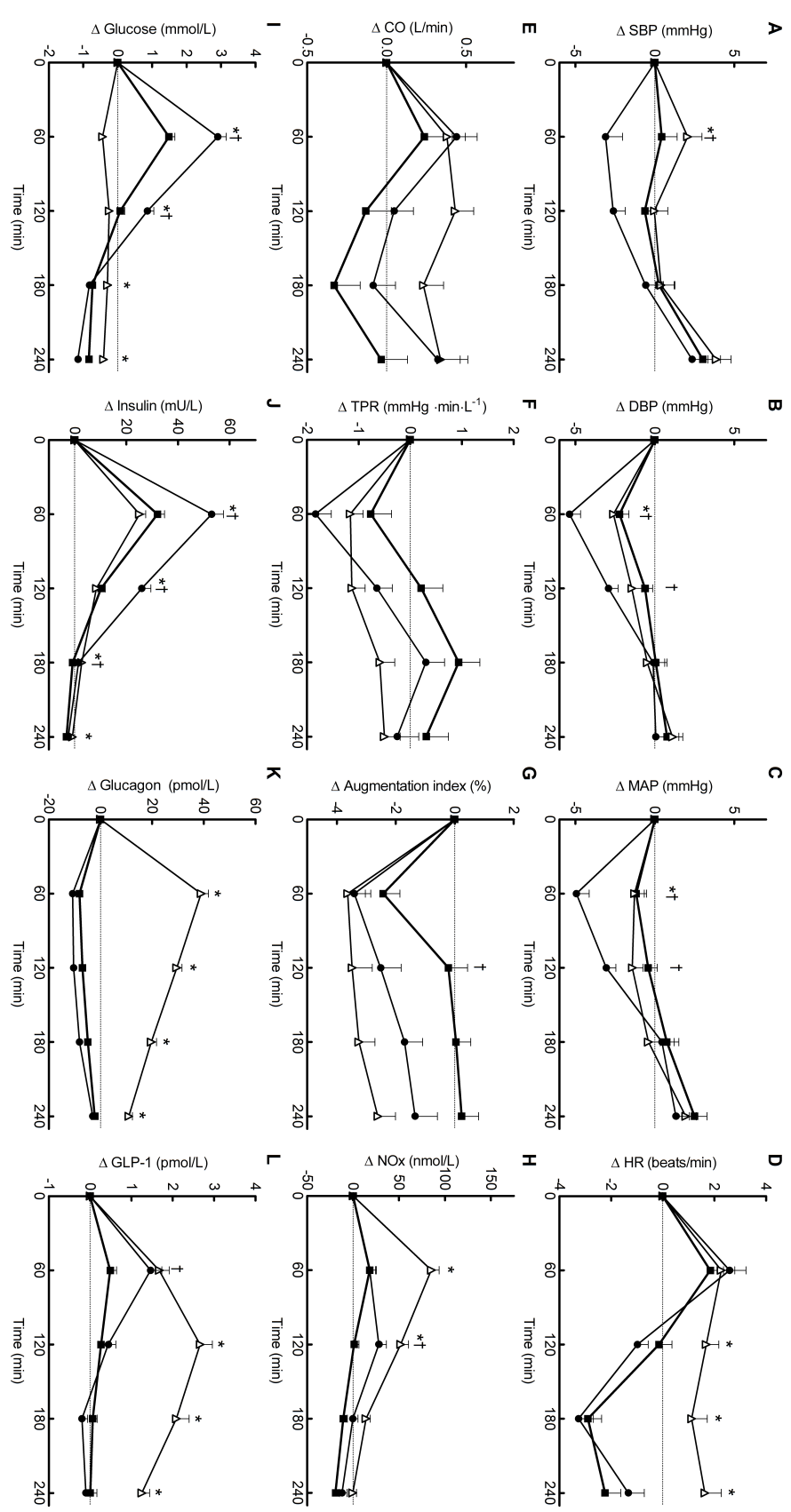
and MAP were also significantly lower after the ingestion of the maltodextrin meal than after that of the sucrose meal after $2 \mathrm{~h}(\mathrm{P} \leq 0.004$, fig. $2(\mathrm{a})-(\mathrm{c}))$. TPR was significantly decreased after the ingestion of the protein mix meal (iAUC, $P=0.0001$, figure 2(f)), while $\mathrm{HR}$ and $\mathrm{CO}$ were significantly increased after the ingestion of this meal (iAUC, $P \leq 0.001$, fig. 2(d) and (e)). TPR, CO and HR did not change significantly after the ingestion of the maltodextrin or sucrose meal. Postprandial HR was significantly higher after the ingestion of the protein mix meal than after that of the maltodextrin meal after $2-4 h(P \leq 0.0001$, fig. 2(d)). The Alx was significantly decreased after the ingestion of the maltodextrin and protein mix meals (iAUC, $\mathrm{P} \leq 0.0001$ ), but not after that of the sucrose meal. The Alx was significantly higher at $2 \mathrm{~h}$ after the ingestion of the sucrose meal than after that of the maltodextrin meal ( $P=0.005$, fig. 2(g)).

Plasma NOx concentrations were significantly increased after the ingestion of the protein mix meal (iAUC, $P \leq 0.0001$ ). NOx concentrations were significantly higher at $1-2 \mathrm{~h}$ after the ingestion of the protein mix meal than after that of the maltodextrin meal $(P \leq 0.008)$, but were lower at $2 \mathrm{~h}$ after the ingestion of the sucrose meal than after that of the maltodextrin meal $(P=0.002$, fig. $2(h))$. The ingestion of the maltodextrin meal resulted in significant increases in glucose and insulin concentrations (iAUC, $\leq 0.0001$ ). The ingestion of the sucrose and protein mix meals also increased insulin concentrations (iAUC, $\leq$ 0.0001 ). In addition, the ingestion of the protein mix meal significantly lowered plasma glucose concentrations (iAUC, $\leq 0.0001$, fig. $2(i)-(j)$ ). The ingestion of the maltodextrin meal resulted in significantly higher plasma glucose concentrations at $1-2 \mathrm{~h}$ and serum insulin concentrations at $1-3 \mathrm{~h}$ compared with that of the sucrose meal $(P \leq 0.002)$. Compared with those observed after the ingestion of the protein mix meal, plasma glucose and serum insulin concentrations were significantly higher at $1-2 \mathrm{~h}$ after the ingestion of the maltodextrin meal and significantly lower at 3-4h after that of the maltodextrin meal $(P \leq 0.0001)$. Plasma glucagon concentrations were significantly decreased after the ingestion of the maltodextrin and sucrose meals and significantly increased after the ingestion of the protein mix meal (IAUC, P $\leq 0.0001$, fig. 2(k)). Glucagon concentrations observed after the ingestion of the maltodextrin meal did not differ from those observed after the ingestion of the sucrose meal. Glucagon concentrations were significantly higher after the ingestion of the protein mix meal than after that of the maltodextrin meal at $1-4 \mathrm{~h}(\mathrm{P} \leq 0.0001)$. GLP-1 concentrations were significantly increased after the ingestion of the maltodextrin and protein mix meals (IAUC, $P \leq 0.0001$, fig. $2(I)$ ). GLP-1 concentrations were significantly higher at $1 \mathrm{~h}$ after the ingestion of the maltodextrin meal than after that of the sucrose meal $(P \leq 0.0001)$. After $2-4 h, G L P-1$ concentrations were significantly higher after the ingestion of the protein mix meal than after that of the maltodextrin meal ( $P \leq 0.0001$, fig. $2(I))$. ACE activity was significantly decreased after the ingestion of the maltodextrin and protein mix meals $(P \leq 0.001$, data 
not shown); however, there were no differences in the postprandial ACE activity responses to the ingestion of the maltodextrin, sucrose and protein mix meals.

\section{DISCUSSION}

In the present study, we compared the acute postprandial BP-related responses to the ingestion of egg-white, milk and pea proteins and we compared postprandial BP-related responses to the ingestion of maltodextrin with those to the ingestion of sucrose and a protein mix.

When comparing the protein sources, egg-white-protein was found to induce the highest postprandial BP levels compared with the pea and milk proteins. We hypothesised that NO-induced vasodilation might be the mechanism responsible for lowering TPR and consequently BP. The higher BP levels and lower NOx response observed after the ingestion of the egg-white-protein meal compared with the levels observed after the ingestion of the pea-protein meal are in agreement with this hypothesis, but the BP levels following the ingestion of the milk-protein meal were lower than those following the ingestion of the egg-white-protein meal, despite a similar NOx response. An additional mechanism, such as ACE inhibition, might have influenced the BP response after the ingestion of the milk-protein meal (23), but we did not find significant differences in the postprandial plasma ACE activity responses to the ingestion of the protein meals. In addition, we found no differences in TPR or in CO responses to the ingestion of the protein sources. We also hypothesised that NO could be induced by insulin, glucagon and GLP-1 $(9,10,15)$. In accordance with this, pea protein induced the highest hormonal and NOx responses, while egg-white-protein induced the lowest responses. The higher amount of arginine in pea protein could have also contributed to the higher NOx response (8). However, milk protein induced a low NOx response despite inducing intermediate hormonal responses. NO regulation is complex and is influenced by many pathways. For instance, leptin is also known to induce NO (24), while glucagon can counteract insulininduced NO release (16). In addition, several proteins and amino acids have been reported to affect NO synthesis in a variety of tissues (25).

The Alx was decreased after the ingestion of all the three protein meals, which indicates that the diameter or distensibility of arteries or arterioles was increased (26). A postprandial decrease in Alx has been reported previously (27). The smaller decrease in Alx after the ingestion of the egg-white-protein meal could be due to the lower insulin response. Westerbacka et al. (26) demonstrated that a physiological dose of insulin can decrease Alx within $1 \mathrm{~h}$.

Differences in insulin- and glucagon-stimulating properties of different proteins have been reported previously $(11,13,28)$ and may be explained by differences in the amino acid 
composition. Phenylalanine and glycine, which are present in highest amounts in pea protein, have been found to be more insulinotropic compared with other amino acids (12). Glycine and arginine, also most abundant in pea protein, have been found to have higher glucagon-stimulating properties (12). Branched-chain amino acids, which are more common in milk proteins, have also been reported to have higher insulin-stimulating properties (11). Differences in the rate of digestion can also influence postprandial insulin responses as shown in studies comparing insulin responses to the consumption of the fast protein whey and the slow protein casein $(29,30)$. However, the relative rates of digestion of the proteins in the present study are unknown. GLP-1 responses to the ingestion of the different protein sources did not seem to differ much. Limited and conflicting data have been reported in the literature on the effects of different proteins on GLP-1 concentrations. No differences were found in GLP-1 concentrations by two studies after the consumption of meals containing $18 \mathrm{~g}$ of milk, cheese, whey, cod or wheat gluten protein combined with $25 \mathrm{~g}$ of carbohydrates (31) or after the consumption of different amino acid mixtures containing isoleucine, leucine, valine and/or threonine, lysine and whey protein all supplemented with $25 \mathrm{~g}$ carbohydrates (32). A higher GLP-1 response was found by one study after the consumption of whey protein than after that of casein (14). Thus, as hypothesised, the lower BP levels observed after the ingestion of the peaprotein meal compared with the levels observed after the ingestion of the egg-whiteprotein meal was accompanied by higher NOx, insulin, glucagon and GLP-1 responses. However, the lower BP response and higher insulin, glucagon and GLP-1 responses observed after the ingestion of the milk-protein meal compared with the responses observed after the ingestion of the egg-white-protein meal were not accompanied by higher plasma NOx concentrations. Therefore, lower postprandial BP levels and higher concentrations of serum insulin and plasma glucagon and GLP-1 are not always accompanied by higher plasma NOx concentrations.

When comparing maltodextrin and sucrose, we found significantly lower BP levels after the ingestion of the maltodextrin meal. It has previously been suggested that this may be due to the fructose content of sucrose, but a recent meta-analysis has found no significant effect of prolonged fructose intake on BP in human trials (33). We hypothesised that the lower BP levels could be due to a higher NOx response. Indeed, we found significantly higher NOx concentrations after the ingestion of the maltodextrin meal, but only at $2 \mathrm{~h}$. We did not find significant changes in TPR, CO and HR after the ingestion of either carbohydrate. An acute study in healthy subjects found a higher BP increase after fructose consumption than after glucose consumption (19). In contrast to the present study, this study also reported a greater decrease in TPR and a greater increase in CO after glucose consumption (19). A study in healthy elderly subjects (65-78 years) reported that the 
decrease in SBP, DBP and MAP was similar $1 \mathrm{~h}$ after the consumption of a beverage containing $50 \mathrm{~g}$ glucose compared with that observed after the consumption of a beverage containing sucrose (34). Another study comparing a glucose drink with a glucose-fructose drink (45 g glucose and $55 \mathrm{~g}$ fructose) only found a higher HR after the consumption of the glucose-fructose drink with no differences being detected in BP, PWV and nitrite:nitrate in 90 min AUC (35). The higher insulin and GLP-1 responses induced by the higher glucose content of maltodextrin in combination with the higher NOx response compared with the responses observed after the ingestion of the sucrose meal support our second hypothesis that NOx may be induced by these hormones. Others have also reported higher insulin responses after the consumption of glucose than after that of fructose (36-38), while GLP-1 concentrations have been found either to be higher (36) or to not differ (38). However, the time points at which the differences in insulin and GLP-1 responses were observed in the present study were not completely in agreement with our hypothesis, as the concentrations of both hormones were highest after $1 \mathrm{~h}$, while NOx concentrations were higher at $2 \mathrm{~h}$. The Alx was significantly lower after the ingestion of the maltodextrin meal than after that of the sucrose meal at $2 \mathrm{~h}$, which may be due to the higher insulin response (26).

When comparing BP responses to the ingestion of the protein mix and maltodextrin, we did find lower BP levels at $1 \mathrm{~h}$ after the ingestion of the maltodextrin meal, as we found in the PROPRES study (7). In contrast to the PROPRES study, in which both the carbohydrate and protein meals induced a decrease in BP, the protein meals induced no change or an increase in $\mathrm{BP}$ in the present study. However, in the present study, proteins and maltodextrin were tested separately, while in the PROPRES study both were consumed with a mixed meal (7). We hypothesised that lower postprandial BP levels would be accompanied by a higher NOx concentration, which decreases TPR by inducing vasodilation. The NOx response was higher after the ingestion of the protein mix meal, which could have contributed to the decrease in TPR. The reduction in TPR induced by the protein mix was accompanied by increases in $\mathrm{HR}$ and $\mathrm{CO}$, which may explain why BP was not significantly affected by the protein mix. Despite these significant haemodynamic changes after the ingestion of the protein mix meal, we did not find significant differences in TPR, $\mathrm{CO}$ and $\mathrm{HR}$ responses to the ingestion of the protein mix and maltodextrin meals, while we did find a difference in TPR responses in the PROPRES study (7). It may be that the energy content of the test meals used in the present study was not high enough to detect differences in TPR responses to the ingestion of the test meals. As maltodextrin did not induce a significant change in CO or TPR, it is not clear from our data why BP was reduced after the ingestion of the maltodextrin meal.

Our second hypothesis was that higher NOx responses might be accompanied by increased concentrations of insulin, GLP-1 and glucagon, as these hormones may induce 
their vasoactive properties via NO-dependent vasodilation $(9,10,17)$. In accordance with this, the higher NOx response observed after the ingestion of the protein mix meal was accompanied by higher GLP-1 and glucagon responses. GLP-1 responses observed after the ingestion of dietary proteins have been reported to be either higher than (38) or similar to $(39,40)$ those observed after the ingestion of carbohydrates. However, the study carried out by Li et al. (40) measured GLP-1 responses only once after $36 \mathrm{~min}$, while in the present study the difference in GLP-1 responses was detected after $120 \mathrm{~min}$. Karamanlis et al. (39) did measure responses at $180 \mathrm{~min}$, but their study may have been underpowered to detect differences in GLP-1-responses, because it included only nine subjects. The higher glucagon response observed after protein consumption was expected, because the maltodextrin-stimulated insulin increase would inhibit glucagon release to maintain glucose homeostasis, while dietary protein is known to be a stimulus for glucagon release (11). In addition, arginine, which was present in the protein mix, could also have contributed to the higher NOx response after protein consumption (8). In our previous study, we had hypothesised that the increase in insulin response after maltodextrin intake could have induced the decrease in BP after maltodextrin intake (7). In the present study, however, we found no maltodextrin-induced changes in TPR or NOx responses to support this hypothesis. In addition, no differences were observed in the Alx and ACE activity responses to the ingestion of the maltodextrin and protein mix meals. Therefore, the mechanisms involved in the decrease of BP after maltodextrin consumption remain unknown.

The increased or unchanged BP levels observed after protein consumption in the present study contradict the BP-lowering effect after long-term consumption of dietary proteins that has been reported in many studies $(1,2)$. However, the PROPRES study has already demonstrated that postprandial responses are not necessarily similar to the effects of long-term consumption (7). High-carbohydrate diets could increase BP in the long term via insulin-induced $\mathrm{Na}$ retention, because insulin reduces hyperglycaemia-induced $\mathrm{Na}$ excretion (41). As we included only participants with fasting glucose levels $<7 \mathrm{mmol} / \mathrm{L}$ it is unlikely that this mechanism plays a role in the subjects of the present study. Supporting this, we found no differences in Na excretion in urine samples collected after each test (data not shown). Postprandial responses cannot be directly extrapolated to the effects of chronic protein consumption. Therefore, long-term studies are necessary to determine which protein source could be most beneficial in BP management.

In conclusion, we found no significant differences in TPR responses after the ingestion of the six meals. Higher BP responses were found after the ingestion of the egg-whiteprotein meal than after that of the pea- and milk-protein meals and lower BP after the ingestion of the maltodextrin meal than after that of the protein mix and sucrose meals. 
However, larger postprandial reductions in BP after the ingestion of different meals are not necessarily accompanied by higher increases in NOx concentrations. This is not surprising as BP is regulated by many factors not by NO only. We also found that higher postprandial NOx responses were not necessarily accompanied by higher insulin, glucagon and GLP-1 concentrations. Mechanisms through which different proteins and carbohydrates acutely affect TPR and BP remain unclear. These data reveal that different protein and carbohydrate sources can induce different postprandial BP-related responses and thus effects of chronic consumption may also differ between different protein sources.

\section{ACKNOWLEDGEMENTS}

The authors thank all the study participants for their contributions to the trial. They also thank Harrie Robins, Thijs Käfer, Frank Engel, Floor van den Brand and Imco Janssen for their work on the test days and on the finalisation of the data set. They also thank Jos op't Roodt for sharing his expertise on the different measurements.

The present study was funded by the Top Institute Food and Nutrition (project no. A1003), Wageningen, The Netherlands. Top Institute Food and Nutrition is a public-private partnership of science, industry and government conducting strategic research in food and nutrition (http://www.tifn.nl). Top Institute Food and Nutrition had no role in the design and analysis of the study or in the writing of this article.

The authors' contributions are as follows: J. D., M. A. v. B., E. J. B., J. M. G., P. W. d. L. and S. J. L. B. designed the study; J. D., K. F. M. T-B., and M. A. v. B. conducted the study; K. F. M. T-B., M. A. v. B. and J. S. analysed the data; K. F. M. T-B., M. A. v. B., J. D., E. J. B., J. M. G., P. W. d. L., S. J. L. B. and J. S. wrote the paper; M. A. v. B. had primary responsibility for final content. All authors read and approved the final manuscript. None of the authors has any conflicts of interest to declare. 


\section{REFERENCES}

1. Rebholz CM, Friedman EE, Powers LJ, Arroyave WD, He J, Kelly TN. Dietary protein intake and blood pressure: a meta-analysis of randomized controlled trials. Am J Epidemiol. 2012;176 Suppl 7:S27-43.

2. Tielemans SM, Altorf-van der Kuil W, Engberink MF, Brink EJ, van Baak MA, Bakker SJ, et al. Intake of total protein, plant protein and animal protein in relation to blood pressure: a meta-analysis of observational and intervention studies. J Hum Hypertens. 2013;27(9):564-71.

3. Teunissen-Beekman KF, van Baak MA. The role of dietary protein in blood pressure regulation. Curr Opin Lipidol. 2013;24(1):65-70.

4. Dong JY, Tong X, Wu ZW, Xun PC, He K, Qin LQ. Effect of soya protein on blood pressure: a meta-analysis of randomised controlled trials. Br J Nutr. 2011;106(3):317-26.

5. Pal S, Ellis V. Acute effects of whey protein isolate on blood pressure, vascular function and inflammatory markers in overweight postmenopausal women. Br J Nutr. 2011;105(10):1512-9.

6. Teunissen-Beekman KF, Dopheide J, Geleijnse JM, Bakker SJ, Brink EJ, de Leeuw PW, et al. Protein supplementation lowers blood pressure in overweight adults: effect of dietary proteins on blood pressure (PROPRES), a randomized trial. Am J Clin Nutr. 2012;95(4):966-71.

7. Teunissen-Beekman KF, Dopheide J, Geleijnse JM, Bakker SJ, Brink EJ, de Leeuw PW, et al. Blood pressure decreases more after high-carbohydrate meals than after high-protein meals in overweight adults with elevated blood pressure, but there is no difference after 4 weeks of consuming a carbohydrate-rich or protein-rich diet. J Nutr. 2013;143(4):424-9.

8. Bode-Boger SM, Boger RH, Galland A, Tsikas D, Frolich JC. L-arginine-induced vasodilation in healthy humans: pharmacokinetic-pharmacodynamic relationship. Br J Clin Pharmacol. 1998;46(5):489-97.

9. Wang B, Ni Y, Zhong J, Sun F. Effects of incretins on blood pressure: a promising therapy for type 2 diabetes mellitus with hypertension. J Diabetes. 2012;4(1):22-9.

10. Scherrer U, Sartori C. Insulin as a vascular and sympathoexcitatory hormone: implications for blood pressure regulation, insulin sensitivity, and cardiovascular morbidity. Circulation. 1997;96(11):4104-13.

11. Claessens M, Calame W, Siemensma AD, van Baak MA, Saris WH. The effect of different protein hydrolysate/carbohydrate mixtures on postprandial glucagon and insulin responses in healthy subjects. Eur J Clin Nutr. 2009;63(1):48-56.

12. Gannon MC, Nuttall FQ. Amino acid ingestion and glucose metabolism--a review. IUBMB Life. 2010;62(9):660-8.

13. van Loon $\mathrm{L}$, Saris $W H$, Verhagen $H$, Wagenmakers AJ. Plasma insulin responses after ingestion of different amino acid or protein mixtures with carbohydrate. Am J Clin Nutr. 2000;72(1):96-105.

14. Hall WL, Millward DJ, Long SJ, Morgan LM. Casein and whey exert different effects on plasma amino acid profiles, gastrointestinal hormone secretion and appetite. Br J Nutr. 2003;89(2):239-48.

15. Farah AE. Glucagon and the circulation. Pharmacol Rev. 1983;35(3):181-217.

16. Ding Y, Vaziri ND, Coulson R, Kamanna VS, Roh DD. Effects of simulated hyperglycemia, insulin, and glucagon on endothelial nitric oxide synthase expression. Am J Physiol Endocrinol Metab. 2000;279(1):E11-7.

17. Farghali $\mathrm{H}$, Hodis J, Kutinova-Canova N, Potmesil P, Kmonickova E, Zidek Z. Glucose release as a response to glucagon in rat hepatocyte culture: involvement of NO signaling. Physiol Res. 2008;57(4):569-75.

18. Altorf-van der Kuil W, Engberink MF, Brink EJ, van Baak MA, Bakker SJ, Navis G, et al. Dietary protein and blood pressure: a systematic review. PLoS One. 2010;5(8):e12102.

19. Brown CM, Dulloo AG, Yepuri G, Montani JP. Fructose ingestion acutely elevates blood pressure in healthy young humans. Am J Physiol Regul Integr Comp Physiol. 2008;294(3):R730-7.

20. O'Brien E, Mee F, Atkins N, O'Malley K. Accuracy of the SpaceLabs 90207 determined by the British Hypertension Society protocol. J Hypertens. 1991;9(6):573-4.

21. Azabji Kenfack M, Lador F, Licker M, Moia C, Tam E, Capelli C, et al. Cardiac output by Modelflow method from intra-arterial and fingertip pulse pressure profiles. Clin Sci (Lond). 2004;106(4):365-9.

22. Appeldoorn MM, Venema DP, Peters TH, Koenen ME, Arts IC, Vincken JP, et al. Some phenolic compounds increase the nitric oxide level in endothelial cells in vitro. J Agric Food Chem. 2009;57(17):7693-9. 
23. Qin LQ, Xu JY, Dong JY, Zhao Y, van Bladeren P, Zhang W. Lactotripeptides intake and blood pressure management: a meta-analysis of randomised controlled clinical trials. Nutr Metab Cardiovasc Dis. 2013;23(5):395-402.

24. Trovati M, Doronzo G, Barale C, Vaccheris C, Russo I, Cavalot F. Leptin and vascular smooth muscle cells. Curr Pharm Des. 2014;20(4):625-34.

25. Li X, Bazer FW, Gao H, Jobgen W, Johnson GA, Li P, et al. Amino acids and gaseous signaling. Amino Acids. 2009;37(1):65-78.

26. Westerbacka J, Wilkinson I, Cockcroft J, Utriainen T, Vehkavaara S, Yki-Jarvinen H. Diminished wave reflection in the aorta. A novel physiological action of insulin on large blood vessels. Hypertension. 1999;33(5):1118-22.

27. Funada J, Takata Y, Hashida H, Matsumoto Y, Sato S, Hiasa G, et al. Dysfunctional central hemodynamic regulation after daily meal intake in metabolic syndrome. Atherosclerosis. 2010;210(1):268-73.

28. Morifuji M, Ishizaka M, Baba S, Fukuda K, Matsumoto H, Koga J, et al. Comparison of different sources and degrees of hydrolysis of dietary protein: effect on plasma amino acids, dipeptides, and insulin responses in human subjects. J Agric Food Chem. 2010;58(15):8788-97.

29. Anderson GH, Tecimer SN, Shah D, Zafar TA. Protein source, quantity, and time of consumption determine the effect of proteins on short-term food intake in young men. J Nutr. 2004;134(11):3011-5.

30. Pal S, Ellis V. The acute effects of four protein meals on insulin, glucose, appetite and energy intake in lean men. Br J Nutr. 2010;104(8):1241-8.

31. Nilsson M, Stenberg M, Frid AH, Holst JJ, Bjorck IM. Glycemia and insulinemia in healthy subjects after lactose-equivalent meals of milk and other food proteins: the role of plasma amino acids and incretins. Am J Clin Nutr. 2004;80(5):1246-53.

32. Nilsson M, Holst JJ, Bjorck IM. Metabolic effects of amino acid mixtures and whey protein in healthy subjects: studies using glucose-equivalent drinks. Am J Clin Nutr. 2007;85(4):996-1004.

33. Ha V, Sievenpiper JL, de Souza RJ, Chiavaroli L, Wang DD, Cozma Al, et al. Effect of fructose on blood pressure: a systematic review and meta-analysis of controlled feeding trials. Hypertension. 2012;59(4):787-95.

34. Visvanathan $R$, Chen R, Garcia M, Horowitz $M$, Chapman I. The effects of drinks made from simple sugars on blood pressure in healthy older people. Br J Nutr. 2005;93(5):575-9.

35. Bidwell AJ, Holmstrup ME, Doyle RP, Fairchild TJ. Assessment of endothelial function and blood metabolite status following acute ingestion of a fructose-containing beverage. Acta Physiol (Oxf). 2010;200(1):35-43.

36. Kong MF, Chapman I, Goble E, Wishart J, Wittert G, Morris H, et al. Effects of oral fructose and glucose on plasma GLP-1 and appetite in normal subjects. Peptides. 1999;20(5):545-51.

37. Stanhope KL, Griffen SC, Bair BR, Swarbrick MM, Keim NL, Havel PJ. Twenty-four-hour endocrine and metabolic profiles following consumption of high-fructose corn syrup-, sucrose-, fructose-, and glucosesweetened beverages with meals. Am J Clin Nutr. 2008;87(5):1194-203.

38. Bowen J, Noakes M, Clifton PM. Appetite hormones and energy intake in obese men after consumption of fructose, glucose and whey protein beverages. Int J Obes (Lond). 2007;31(11):1696-703.

39. Karamanlis A, Chaikomin R, Doran S, Bellon M, Bartholomeusz FD, Wishart JM, et al. Effects of protein on glycemic and incretin responses and gastric emptying after oral glucose in healthy subjects. Am J Clin Nutr. 2007;86(5):1364-8.

40. Li J, An R, Zhang Y, Li X, Wang S. Correlations of macronutrient-induced functional magnetic resonance imaging signal changes in human brain and gut hormone responses. Am J Clin Nutr. 2012;96(2):275-82.

41. Brands MW, Manhiani MM. Sodium-retaining effect of insulin in diabetes. Am J Physiol Regul Integr Comp Physiol. 2012;303(11):R1101-9. 



\section{Chapter 6}

Effects of dietary proteins and carbohydrates on markers of endothelial function and lowgrade inflammation

In preparation

Karianna F.M. Teunissen-Beekman Janneke Dopheide Johanna M. Geleijnse Stephan J.L. Bakker Elizabeth J. Brink Peter W. de Leeuw Casper G. Schalkwijk Marleen A. van Baak 


\begin{abstract}
Introduction

Endothelial dysfunction (ED) and low-grade inflammation (LGI) play a role in the development of cardiovascular diseases. This study explored effects of dietary proteins and carbohydrates on markers of ED and LGI in overweight individuals with untreated elevated blood pressure.
\end{abstract}

Methods

In an initial study, participants consumed a protein mix or maltodextrin ( $3 \times 20 \mathrm{~g} /$ day) for 4 weeks. Fasting levels and $12 \mathrm{~h}$-postprandial responses of markers of ED (soluble intercellular adhesion molecule 1 (sICAM), soluble vascular cell adhesion molecule 1 (sVCAM), soluble endothelial selectin (sE-selectin), and von Willebrand factor (vWf)), and markers of LGI (serum amyloid A (SAA), C-reactive protein (CRP), and sICAM) were evaluated before and after intervention. Biomarkers were also combined into mean Zscores of ED and LGI. In a second study, 4h-postprandial responses of ED and LGI markers were compared after ingestion of $0.6 \mathrm{~g} / \mathrm{kg}$ pea protein, milk protein and egg-white protein. Also, postprandial responses after maltodextrin intake were compared to a protein mix and sucrose.

Results

After 4 weeks, fasting ED Z-scores and sICAM were significantly lower after the high protein diet compared to the maltodextrin diet $(P \leq 0.02)$. Postprandial Z-scores and biomarkers of ED and LGI did not clearly differ between test meals. But postprandial sVCAM decreased more after the protein mix compared to maltodextrin in both studies $(P$ $\leq 0.04)$.

Discussion

After 4 weeks of supplementation, dietary protein is beneficial for fasting ED, but not for fasting LGI. Based on Z-scores, postprandial ED and LGI were not differentially affected by protein sources or carbohydrates. 


\section{INTRODUCTION}

Consumption of dietary proteins at the expense of carbohydrates lowers blood pressure $(1,2)$, and mechanisms through which proteins affect blood pressure need to be clarified. Endothelial dysfunction (ED) and low-grade inflammation (LGI) are important factors in the progression of cardiovascular diseases $(3,4)$ and are associated with hypertension (4, $5)$. Both macronutrient and micronutrient intake have been found to affect levels of biomarkers of ED and LGI $(6,7)$. However, thus far no clear effects of long-term increased protein intake on levels of C-reactive protein (CRP) (8-12), interleukin 6 (IL-6), tumor necrosis factor $\alpha$ (TNF $\alpha)$ (8-11), soluble E-selectin (sE-selectin), soluble intercellular adhesion molecule 1 (sICAM) and soluble vascular cell adhesion molecule 1 (sVCAM) (9, 10) have been found.

Although effects of high calorie high fat meals on postprandial levels of markers of ED and LGI have been studied frequently (13-15), effects of protein and carbohydrate intake on postprandial changes in markers of ED and LGI have been investigated less often. In healthy volunteers glucose intake was found to increase SICAM, sVCAM, sE-selectin, IL-6 and CRP postprandially compared to fasting values (16). Others found no effect of carbohydrate intake on postprandial levels of sICAM, sVCAM, IL-6 $(17,18)$, CRP and sEselectin (18). With regard to dietary proteins, postprandial responses of markers of ED and LGI to protein intake did not differ from those after carbohydrate intake (19) or placebo (10).

We previously reported a blood-pressure lowering effect after 4 weeks consumption of a protein mix compared with maltodextrin in the randomized clinical trial on the effects of PROteins on blood PRESsure (PROPRES) (20). The present study aimed to explore chronic and postprandial effects of protein intake compared with carbohydrate intake on ED and LGI. We hypothesized that fasting levels of markers of ED and LGI would be lower after 4 weeks on the high protein diet compared to the high maltodextrin diet in the PROPRES study and thus might contribute to the lower blood pressure reported earlier (20). To determine whether possible chronic effects of dietary protein on ED and LGI can also be observed acutely, we compared postprandial levels of markers of ED and LGI after ingestion of protein- and maltodextrin-supplemented meals on the first and last day of the intervention in the PROPRES trial. A second postprandial study was conducted to investigate whether different types of proteins or carbohydrates would differentially affect postprandial responses of ED and LGI. 


\section{METHODS}

\section{Study population}

The first study was performed in a subset of the study participants of the PROPRES study $(\mathrm{N}=52)(21)$, which consisted of a chronic, 4-week intervention, and postprandial studies with postprandial assessments on the first and last day of the intervention. Participants in the chronic and postprandial parts of the PROPRES study were overweight and obese individuals with untreated elevated blood pressure (SBP of 130-159 $\mathrm{mmHg}$ and/or DBP of 85-99 $\mathrm{mmHg}$ ). More information of inclusion and exclusion criteria are described elsewhere (20). In the second study, which consisted of a cross-over evaluation of postprandial effects, participants had similar characteristics as in the first study and part of this study group had also participated in the PROPRES study (22). Both, the first and second study were approved by the medical ethics committee of Maastricht University Medical Center and Maastricht University (METC azM/UM) and all participants gave written informed consent.

\section{CHRONIC STUDY}

The chronic part of the PROPRES trial had a parallel group design and compared the effects of 4 weeks of exchanging dietary carbohydrates isocalorically with either a protein mix ( $3 \times 20 \mathrm{~g} /$ day) or with maltodextrin (3x $20 \mathrm{~g} /$ day) on ED and LGI. More details on the 4week PROPRES trial can be found elsewhere (20).

\section{FIRST POSTPRANDIAL STUDY}

This study was also part of the PROPRES trial. Twelve-hour postprandial responses to standard mixed meals isocalorically supplemented with $20 \mathrm{~g}$ of a protein mixture $(20 \%$ pea protein, $20 \%$ soy protein, $30 \%$ egg-white protein, $30 \%$ milk protein isolates) or with $20 \mathrm{~g}$ of maltodextrin were tested during test days at the start and end of the PROPRES trial. More details on the postprandial part of the PROPRES study can be found elsewhere (21).

\section{SECOND POSTPRANDIAL STUDY}

$4 \mathrm{~h}$ postprandial responses after single ingestion of three types of protein (pea, milk and egg-white protein isolate) and two types of carbohydrate (maltodextrin and sucrose) and the protein mix used in the PROPRES study were assessed in 48 overweight participants with untreated elevated blood pressure in the morning after an overnight fast. The six test meals in this study contained $0.6 \mathrm{~g} / \mathrm{kg}$ body mass of one of the test products. Products were tested in a randomized order crossover design. Comparisons were made between the three protein sources, and responses to the ingestion of maltodextrin were compared to those after the ingestion of sucrose, and those after the protein mix. More details of this study are described elsewhere (22). 


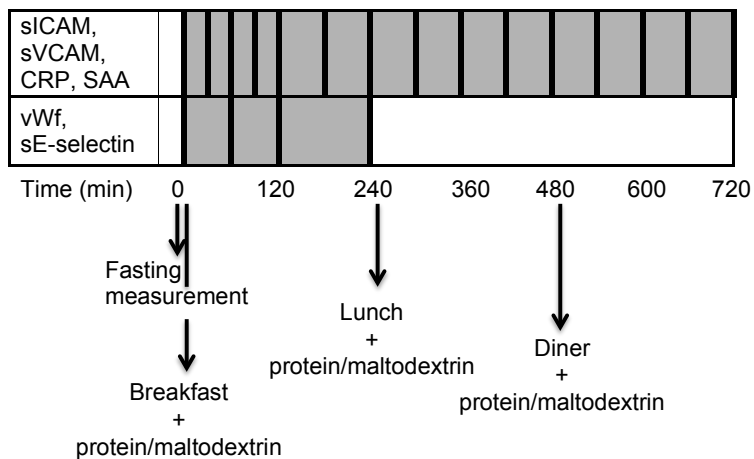

B test day second postprandial study

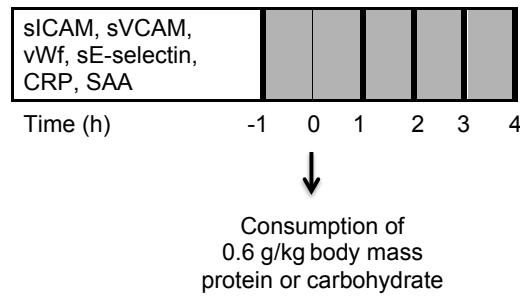

Figure 1. Measurements on the test days in the first postprandial study (panel A) and second postprandial study (panel B). Thick vertical lines represent measurements of parameters mentioned in the same row. CRP, C-reactive protein; ED, endothelial dysfunction; LGI, low-grade inflammation; PROPRES, randomized clinical trial on the effects of PROteins on blood PRESsure; SAA, serum amyloid A; sE-selectin, soluble endothelial selectin; sICAM, soluble intercellular adhesion molecule 1 ; sVCAM, soluble vascular cell adhesion molecule 1; vWf, von Willebrand factor.

\section{Measurements}

\section{CHRONIC STUDY}

Venous blood for measurement of markers of ED (von Willebrand factor ( $v W f$ ), sE-selectin, sICAM and SVCAM) and LGI (CRP, serum amyloid A (SAA) and SICAM) was collected before breakfast in the fasting state on the first and last day of the intervention.

FIRST POSTPRANDIAL STUDY

Postprandial measurements of vWf and sE-selectin were taken at 60, 120 and $240 \mathrm{~min}$ after the protein- or maltodextrin-supplemented breakfast. sICAM, sVCAM, CRP and SAA were measured 30,60,90,120, 180, 240, 300, 360, 420, 480, 540, 600, 660 and 720 min after breakfast (figure $1 \mathrm{~A}$ ). Lunch and dinner were consumed 4 and 8 hours after breakfast respectively. These meals were also supplemented with the protein mix or maltodextrin. More details of the meals are described elsewhere (21). 
SECOND POSTPRANDIAL STUDY

All markers were measured in the fasting state and at 60, 120, 180 and 240 min after the test meal (figure 1B).

Plasma sICAM, sVCAM, sE-selectin, CRP and SAA were assessed using a multi-array detection system based on electro-chemiluminescence technology (SECTOR Imager 2400, Meso Scale Discovery), as previously described (23). vWf was assessed in citrated plasma by means of an enzyme-linked immuno sorbent assay (ELISA) (23).

\section{Statistical analyses}

In addition to responses of individual biomarkers, overall Z-scores for ED and LGI were also analyzed to cope with biological variability of each indivdiual marker (23) and ease interpretation of findings for individual biomarkers. To calculate ED and LGI Z-scores, first a $Z$ was calculated for each individual biomarker as follows $Z$ = (individual value population mean)/population SD. Individual biomarker Z-scores were averaged into the overall Z-scores for ED and LGI. The overall ED Z-scores consisted of the biomarkers sICAM, sVCAM, sE-selectin, and vWf. Overall LGI Z-scores consisted of CRP, SAA, and sICAM. Overall ED Z-scores for the $12 \mathrm{~h}$ test day only included SICAM and SVCAM, because the other markers were not determined after lunch until the end of the test day. Further explanations on the calculation of overall Z-scores can be found elsewhere (23). The population mean and population SD for each individual biomarker were calculated as follows in the different studies: For the chronic study the population mean (and SD) was based on the average of the fasting levels on the first and last day of the intervention. For the first postprandial study the population mean (and SD) was based on the average of all measurements during one test day. For the second postprandial study the population mean (and SD) was based on the average of all measurements during all test days, because this was a crossover trial.

All statistical analyses were performed with SPSS software (version 20; IBM). A $P$ value of $<0.05$ was considered to be significant. CRP and SAA were In-transformed because of their skewed distributions. Participants with CRP values $>10 \mathrm{mg} / \mathrm{L}$ were excluded from analyses, because a CRP value this high indicates presence of inflammation (24), which could confound the postprandial responses.

\section{CHRONIC STUDY}

Differences in fasting values between groups on day 1 of supplementation were tested with an independent samples t-test. Fasting values after 4 weeks were tested with a univariate ANCOVA with the fasting value on day 1 as a covariate.

FIRST POSTPRANDIAL STUDY

Postprandial data on each test day were analyzed by a linear mixed model analysis using a random intercept model. Analyses started off with the full model including group, time, 
fasting measurement, BMI, age and sex. BMI, age and sex were removed from the model one-by-one starting with the least significant covariate to test whether they significantly contributed to the model with a -2 log likelihood test. Significant covariates were kept in final the model. Incremental areas under the curve (iAUCs) were calculated in the PROPRES study and tested for deviance from zero with a one-sample $t$-test to see whether postprandial increases/decreases were significant.

\section{SECOND POSTPRANDIAL STUDY}

Postprandial responses were analyzed with a linear mixed model approach that took the crossover design and the correlation between repeated measures into account. The basic model consisted of a random intercept at the individual level. If significant, this model was extended with a random intercept at the meal within individual level (individual*meal) or with a serial correlation over time. The basic model always included the following variables: time, meal, fasting measurements, and two variables controlling for the crossover design: meal order and test day number. The interaction term between meal and time (meal*time) and the covariates age, gender and BMI were kept in the model if significant. In case of significant meal*time or meal effect, five post hoc comparisons were made i.e. maltodextrin vs. sucrose, maltodextrin vs. protein mix, pea protein vs. milk protein, pea protein vs. egg-white protein, milk protein vs. egg-white protein. The critical $P$-value was corrected for these comparisons, therefore post-hoc differences were considered significant at $P \leq 0.01$ (22).

Table 1. Baseline and 4-week fasting levels (mean \pm SEM) of markers of ED and LGI in the chronic study

\begin{tabular}{|c|c|c|c|c|c|c|}
\hline & \multicolumn{3}{|c|}{ Maltodextrin } & \multicolumn{3}{|c|}{ Protein } \\
\hline & day 1 & 4 weeks & $\mathbf{N}$ & day 1 & 4 weeks & $\mathbf{N}$ \\
\hline ED Z-score & $0.30 \pm 0.18^{*}$ & $0.27 \pm 0.15^{\dagger}$ & 21 & $-0.21 \pm 0.12^{*}$ & $-0.33 \pm 0.10^{\dagger}$ & 22 \\
\hline LGI Z-score & $-0.01 \pm 0.15$ & $0.24 \pm 0.16$ & 24 & $-0.14 \pm 0.18$ & $-0.08 \pm 0.14$ & 25 \\
\hline $\operatorname{sICAM}(\mu \mathrm{g} / \mathrm{L})$ & $215 \pm 8^{*}$ & $224 \pm 8^{\dagger}$ & 24 & $191 \pm 7^{*}$ & $182 \pm 6^{\dagger}$ & 25 \\
\hline sVCAM ( $\mu \mathrm{g} / \mathrm{L})$ & $362 \pm 19$ & $365 \pm 17$ & 24 & $353 \pm 13$ & $351 \pm 13$ & 25 \\
\hline sE-selectin ( $\mu \mathrm{g} / \mathrm{L})$ & $100 \pm 7^{*}$ & $101 \pm 8$ & 21 & $73 \pm 7^{*}$ & $69 \pm 6$ & 22 \\
\hline$v W f(\%)$ & $102 \pm 7$ & $92 \pm 6$ & 21 & $86 \pm 6$ & $86 \pm 6$ & 22 \\
\hline $\mathrm{CRP}(\mathrm{mg} / \mathrm{L})^{1}$ & $1.79 \pm 0.35$ & $2.29 \pm 0.45$ & 24 & $1.51 \pm 0.30$ & $1.50 \pm 0.20$ & 25 \\
\hline $\mathrm{SAA}(\mathrm{mg} / \mathrm{L})^{1}$ & $1.17 \pm 0.23$ & $1.48 \pm 0.28$ & 24 & $1.65 \pm 0.34$ & $1.77 \pm 0.23$ & 25 \\
\hline \multicolumn{7}{|c|}{$\begin{array}{l}{ }^{1} \text { statistical tests were performed with In-transformed data. }{ }^{*} P<0.05 \text { for between-group differences on day } \\
1 \text { tested with an independent samples t-test. }+P<0.05 \text { for between-group differences after } 4 \text { weeks tested } \\
\text { with ANCOVA correcting for the fasting value on day } 1 . \text { CRP, C-reactive protein; ED, endothelial dysfunction; } \\
\text { LGI, low-grade inflammation; PROPRES, randomized clinical trial on the effects of PROteins on blood } \\
\text { PRESsure; sE-selectin, SAA, serum amyloid A; sE-selectin, soluble endothelial selectin; sICAM, soluble } \\
\text { intercellular adhesion molecule } 1 \text {; sVCAM, soluble vascular cell adhesion molecule 1; vWf, von Willebrand } \\
\text { factor. }\end{array}$} \\
\hline
\end{tabular}




\section{RESULTS}

From the 52 participants in the chronic study and first postprandial study (maltodextrin group $\mathrm{N}=27$, protein group $\mathrm{N}=25$ ), three participants in the maltodextrin group were excluded from the present analyses. This was because two participants had CRP values $>10 \mathrm{mg} / \mathrm{L}$ on one of the test days, and another participant had missing fasting values on one test day. In the second postprandial study, product test days were excluded from analyses when a participant had CRP levels $>10 \mathrm{mg} / \mathrm{L}$ during that particular day. As a consequence, one test of sucrose, two tests of pea protein, two tests of milk protein, two tests of egg-white protein, and three tests of the protein mix were excluded from analyses. Baseline characteristics of participants in the first postprandial study and the second postprandial study have been published previously $(21,22)$.

Chronic study: effects of 4 weeks increased protein intake on ED and LGI,

ED Z-scores, sICAM and SE-selectin were significantly lower in the protein group at the start of the intervention ( $P \leq 0.04$, table 1$)$, whereas only baseline-corrected ED Z-scores and sICAM were significantly lower in the protein group after 4 weeks of supplementation, $(P \leq 0.02$, table 1$)$.

First postprandial study: postprandial responses of ED to protein- and maltodextrinsupplemented meals.

Analyses of iAUCs showed significant postprandial decreases on the first day of supplementation and after 4 weeks of supplementation for ED Z-scores, sICAM, sVCAM, and $\mathrm{sE}$-selectin $(P \leq 0.05)$. Postprandial vWf decreased below fasting values on day 1 of supplementation $(P \leq 0.05)$, but not after 4 weeks.

Twelve-hour postprandial levels of ED Z-scores (composed of SICAM, and SVCAM) and sICAM tended to be lower after ingestion of the protein-supplemented meals than after ingestion of the maltodextrin-supplemented meals on day $1(P=0.07, P=0.08$ respectively; figures $2 \mathrm{~A}, \mathrm{C}$ ), but these did not differ significantly after 4 weeks (figure $2 \mathrm{~B}$, D). Postprandial SVCAM levels were significantly lower after ingestion of the proteinsupplemented meals compared with the maltodextrin-supplemented meals after 4 weeks of supplementation ( $P=0.04$, figure $2 \mathrm{~F}$ ), but not on the first day of supplementation (figure 2E). Four-hour postprandial responses of ED Z-scores (composed of sICAM, sVCAM, $\mathrm{sE}$-selectin, and vWf), sE-selectin and vWf did not differ between protein- and maltodextrin-supplemented meals on both test days (data not shown). 

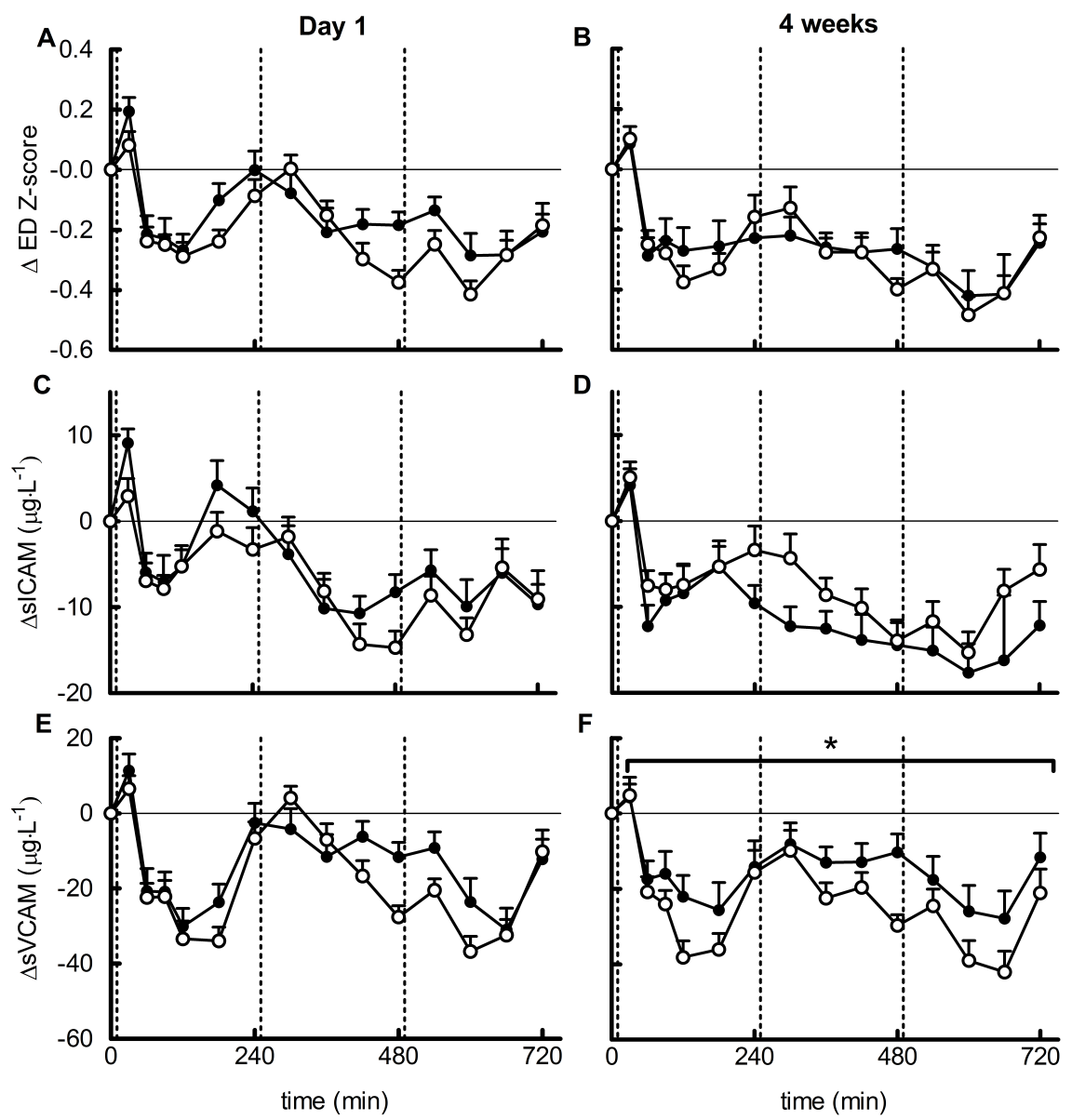

Figure 2. Mean ( \pm SEM) of $12 \mathrm{~h}$ postprandial responses of endothelium function to meals supplemented with protein or maltodextrin on day 1 of supplementation (left) and after 4 weeks of supplementation (right) in the first postprandial study. Panels are ED Z-scores (A, B), sICAM (C, D), sVCAM (E, F). Participants included in analyses maltodextrin group $n=24$, protein group $n=25$. Vertical lines indicate breakfast, lunch, and dinner.

$* \mathrm{P}<0.05$ for the difference between maltodextrin group (black) and protein group (white) over the whole $12 \mathrm{~h}$ period according to the mixed model. ED, endothelial dysfucnction; sICAM, soluble intercellular adhesion molecule 1; sVCAM, soluble vascular cell adhesion molecule 1.

First postprandial study: postprandial responses of LGI to protein- and maltodextrinsupplemented meals.

Analyses of iAUCs revealed significant postprandial decreases of LGI Z-scores (composed of CRP, SAA, and SICAM) on both test days (iAUCs $P \leq 0.05$, figure 3A-B), whereas postprandial CRP levels increased significantly on day 1 and postprandial SAA levels decreased significantly after 4 weeks (iAUCs $P \leq 0.05$, figure 3C, $F$ respectively). Postprandial responses of LGI Z-scores, CRP, and SAA did not differ between protein- and maltodextrin-supplemented meals (figure $3 \mathrm{~A}-\mathrm{F}$ ). 

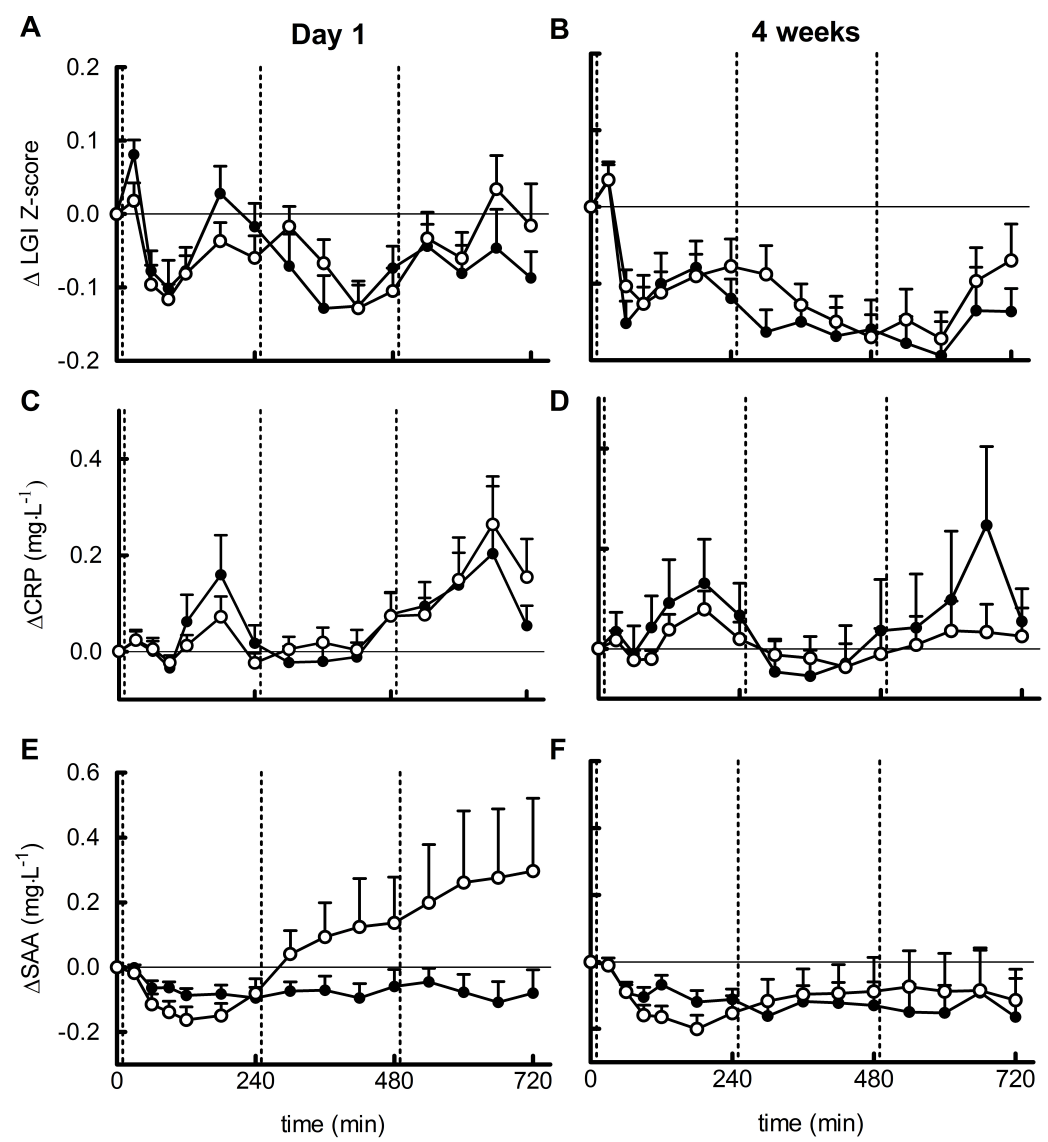

Figure 3. Mean $( \pm \mathrm{SEM}$ ) of $12 \mathrm{~h}$ postprandial responses of low-grade inflammation to meals supplemented with protein or maltodextrin on day 1 of supplementation (left) and after 4 weeks of supplementation (right) in the first postprandial study. Panels are LGI Z-scores (A, B), CRP (C, D), SAA (E, F). Participants included in analyses maltodextrin group $n=24$, protein group $n=25$. Vertical lines indicate breakfast, lunch, and dinner. Postprandial responses did not differ between groups according to the mixed model. CRP, Creactive protein; LGI, low-grade inflammation; SAA, serum amyloid $A$.

Second postprandial study: postprandial responses of ED after consumption of various protein and carbohydrate sources.

Postprandial levels of ED Z-scores did not differ between protein sources or between maltodextrin vs. sucrose or maltodextrin vs. the protein mix (figures $4 A, B$ ). Pea protein consumption induced lower postprandial levels of sICAM compared to egg-white protein consumption $(P \leq 0.001)$. Ingestion of the protein mix resulted in lower postprandial levels of sICAM and SVCAM compared to ingestion of maltodextrin ( $P \leq 0.004$, figures $4 C-F$ ). Postprandial responses of $s E-s e l e c t i n$ and $v W f$ did not differ between test meals (figures and 4G-J). 

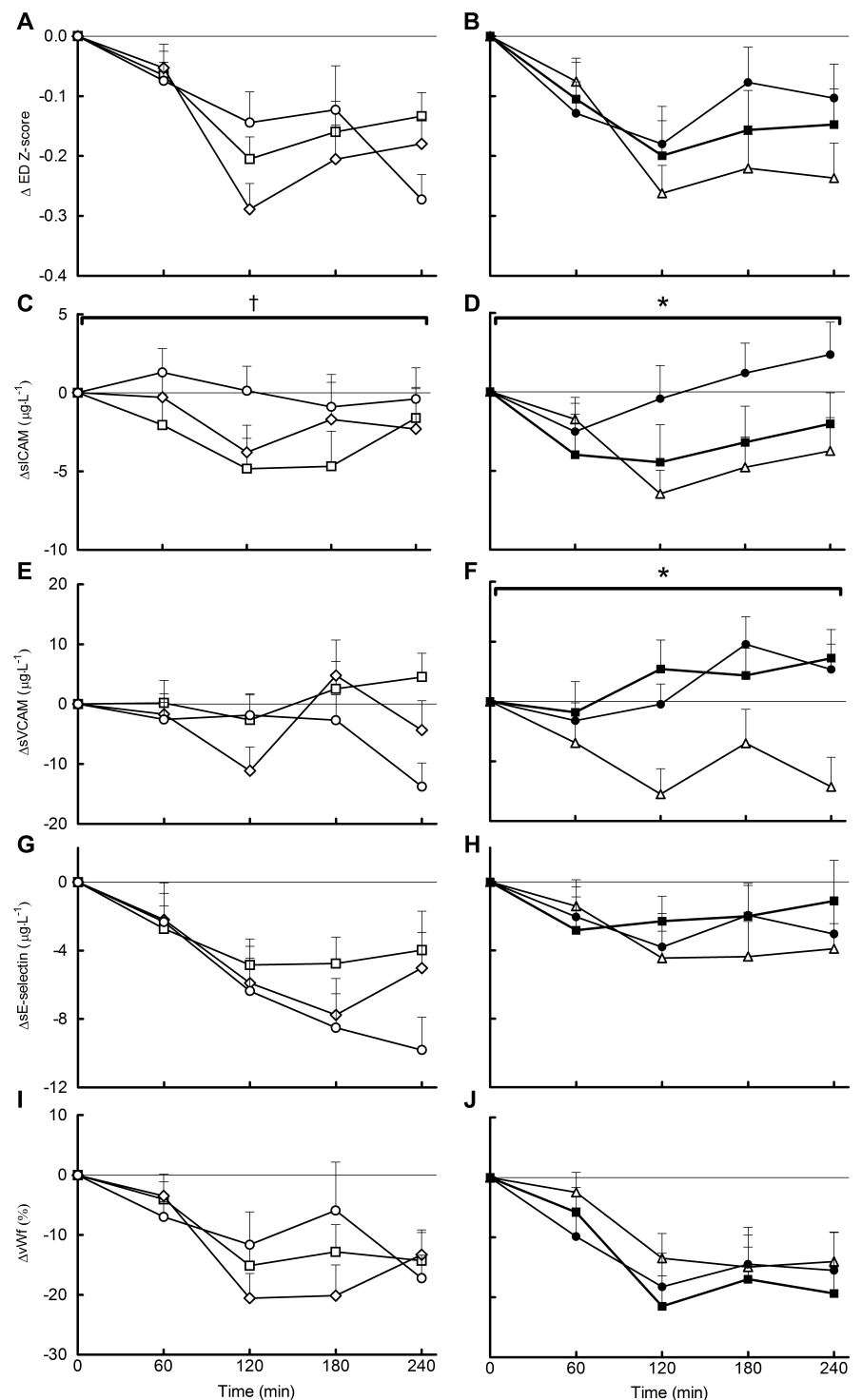

Figure 4. Mean $( \pm S E M)$ of $4 \mathrm{~h}$ postprandial responses of endothelium function to pea protein $(\square)$, milk

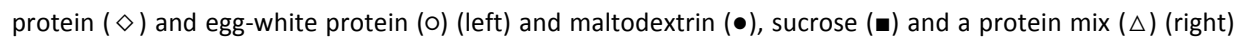
in the second postprandial study. Panels are ED Z-scores (A, B), $\operatorname{sICAM}(C, D), \operatorname{sVCAM}(E, F), \operatorname{sE}$-selectin $(G, H)$, $\mathrm{vWf}(\mathrm{I}, \mathrm{J})$. Participants included in analyses pea protein $\mathrm{n}=45$, milk protein $\mathrm{n}=46$, egg-white protein $\mathrm{n}=45$, maltodextrin $n=47$, sucrose $n=45$, protein mix $n=45$. ${ }^{*}$ significant difference between protein mix and maltodextrin over the whole $4 \mathrm{~h}$ period shown by post-hoc tests with Bonferroni correction $(P \leq 0.01)$ if meal was significant $(P \leq 0.05)$. + significant difference between pea protein and egg-white protein over the whole $4 \mathrm{~h}$ period shown by post-hoc tests with Bonferroni correction $(P \leq 0.01)$ if meal was significant $(P \leq 0.05)$. ED, endothelial dysfunction; sE-selectin, soluble endothelial selectin; sICAM, soluble intercellular adhesion molecule 1; sVCAM, soluble vascular cell adhesion molecule 1; vWf, von Willebrand factor. 

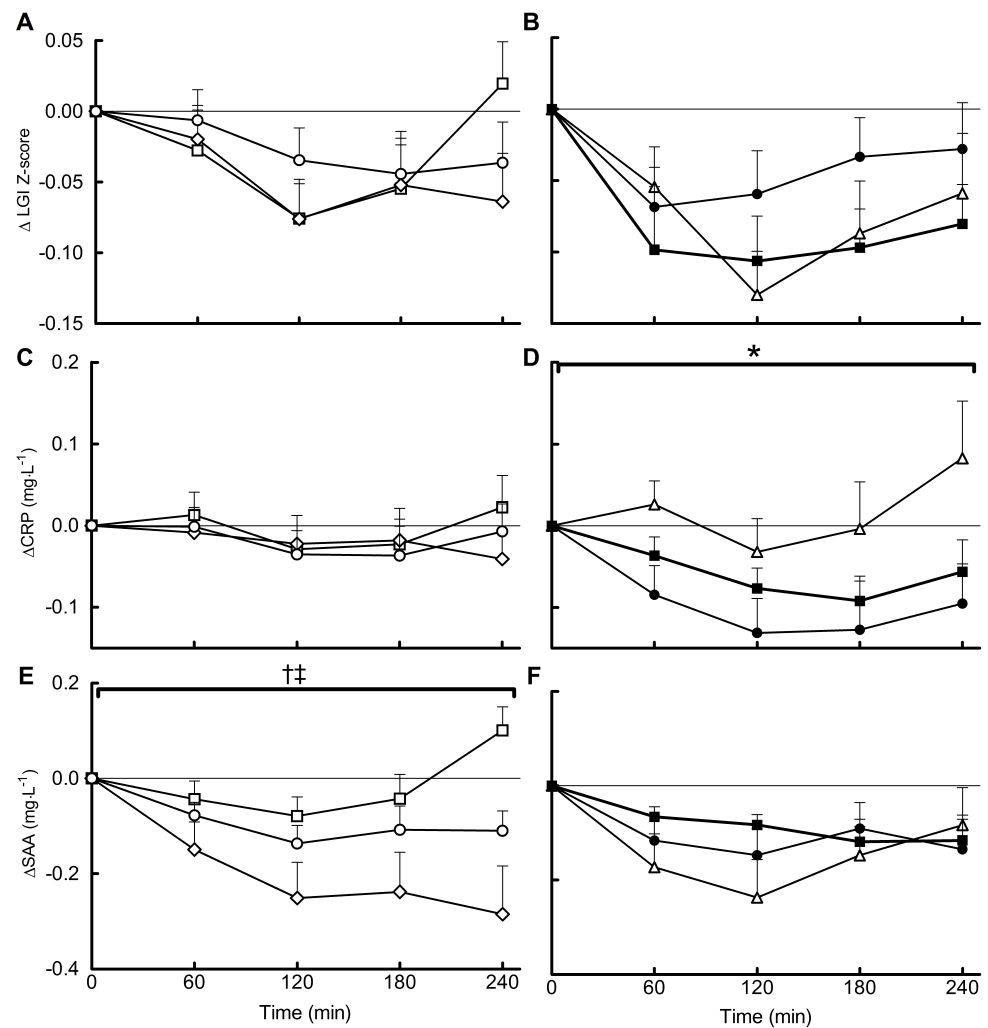

Figure 5. Mean ( \pm SEM) of $4 \mathrm{~h}$ postprandial responses of low-grade inflammation to pea protein $(\square)$, milk protein $(\diamond)$ and egg-white protein (o) (left) and maltodextrin $(\bullet)$, sucrose $(\square)$ and a protein $\operatorname{mix}(\Delta)$ (right) in the second postprandial study. Panels are LGI Z-scores (A, B), CRP (C, D), SAA (E, F). Participants included in analyses pea protein $n=45$, milk protein $n=46$, egg-white protein $n=45$, maltodextrin $n=47$, sucrose $n=45$, protein mix $n=45{ }^{*}$ significant difference between protein mix and maltodextrin over the whole $4 \mathrm{~h}$ period shown by post-hoc tests with Bonferroni correction $(P \leq 0.01)$ if meal was significant $(P \leq 0.05)$.

+ significant difference between pea protein and egg-white protein over the whole $4 \mathrm{~h}$ period shown by post-hoc tests with Bonferroni correction $(P \leq 0.01)$ if meal was significant $(P \leq 0.05)$. $¥$ significant difference between pea protein and milk protein over the whole $4 \mathrm{~h}$ period shown by post-hoc tests with Bonferroni correction $(P \leq 0.01)$ if meal was significant $(P \leq 0.05)$. CRP, C-reactive protein; LGI, low-grade inflammation; SAA, serum amyloid $A$.

Second postprandial study: postprandial responses of LGI after consumption of various protein and carbohydrate sources.

Postprandial responses in LGI Z-scores did not differ between protein sources or between maltodextrin vs. sucrose, or maltodextrin vs. the protein mix (figure 5A,B). Ingestion of pea protein induced higher postprandial SAA levels than ingestion of milk, and egg-white protein $(P<0.001$, figure $5 \mathrm{E}, \mathrm{F})$. Ingestion of the protein mix resulted in higher postprandial CRP levels than ingestion of maltodextrin $(P<0.001$, figure 5C,D). 


\section{DISCUSSION}

\section{Chronic study}

The most important findings in the studies reported here are the lower fasting levels of ED Z-scores and SICAM after 4 weeks on the protein diet compared to the maltodextrin diet in the PROPRES study. Literature data on the effects of protein-enriched diets on fasting levels of markers of ED are relatively scarce. Two weeks consumption of a novel whey derived peptide ( $5 \mathrm{~g} /$ day) did not affect fasting values of $s E$-selectin, sICAM, sVCAM and CRP compared to placebo in healthy individuals (10). Eight weeks consumption of 40 $\mathrm{g} /$ day soybean protein (including isoflavones) lowered fasting levels of $\mathrm{sE}$-selectin compared with intake of $40 \mathrm{~g} /$ day milk protein, but not compared to intake of $40 \mathrm{~g} / \mathrm{day}$ complex carbohydrate. No differences between supplements were found for fasting sICAM and sVCAM levels (9). In contrast to these two studies, we demonstrated a decrease of sICAM levels after the protein mix. One explanation for our finding could be the greater difference in protein intake (60 g/day) between groups in our study. In addition to soy and milk protein our protein mix also consisted of pea protein and eggwhite protein. Therefore, our results are consistent with the view that increased protein intake improves markers of ED within 4 weeks under fasting conditions. This may be related to the dose of protein and/or the mix of protein sources that were tested.

Fasting levels of markers of LGI did not differ between the protein and maltodextrin group after the 4-week intervention. This is consistent with a 12-week trial, which found no differences in fasting concentrations of TNF- $\alpha$, IL- 6 and CRP between a whey-, casein- or glucose-supplemented diet (54 g/day) (11). In another study, fasting CRP levels did not significantly differ after eight weeks of soybean protein or milk protein consumption compared to complex carbohydrate (9). Eight weeks on a high protein weight loss diet (30\% of energy intake) also did not affect fasting CRP levels compared to a high carbohydrate/fiber weight loss diet (20\% of energy intake from protein) (12). Neither did one-week consumption of milk tripeptides versus placebo (25). However, two other studies found unfavorable effects of increased protein intake on LGI. The DIOGENES randomized controlled trial, comparing diets with higher/lower protein content combined with higher/lower glycemic index, found evidence that the lower protein diets were associated with lower fasting CRP concentrations than the higher protein diets (26). A recent weight loss trial found increased inflammation scores after a high protein weight loss diet ( $30 \%$ of energy intake) compared to a normal protein weight loss diet ( $15 \%$ of energy intake), while levels of individual markers CRP, TNF $\alpha$, plasminogen activator inhibitor-1 (PAI-1) and IL-6 did not differ between groups. This increased inflammation score was found especially for high animal and meat protein intake and not for increased vegetable or fish protein intake (8). The protein supplement in our study was only partly 
composed of animal protein (60\%: $30 \%$ milk and 30\% egg-white protein) and not in the form of meat protein, which may explain why we did not find increased LGI in the protein group. Also, the LGI Z-score in our study was composed of other markers (CRP, SAA and sICAM versus CRP, TNF $\alpha$, PAI-1 and IL-6) (8). Thus, we may conclude that increased protein intake has no effect on levels of markers of LGI under fasting conditions, which is in agreement with several studies $(9,12,19,25)$ but contrasts with findings of two food based interventions $(8,26)$. This may be related to differences in the type of proteins included in the diets/supplementents. Moreover, in food-based studies the effects of other food constituents cannot be fully excluded.

\section{First and second postprandial study}

Postprandial sVCAM levels were found to be lower after protein-supplemented meals compared to maltodextrin-supplemented meals after 4 weeks of intervention in the first postprandial study and after consumption of $0.6 \mathrm{~g} / \mathrm{kg}$ of the protein mix compared to maltodextrin in the second postprandial study. Glucose and insulin might be involved in this difference. In a study investigating the effects of ingestion of $75 \mathrm{~g}$ glucose vs. fructose, both carbohydrates induced similar $3 \mathrm{~h}$ postprandial responses of SVCAM despite different postprandial glucose and insulin responses (18), which suggests that glucose and insulin do not modulate postprandial SVCAM levels. We found that other markers of ED and the ED Z-scores did not differ consistently between the protein mix and maltodextrin. Taken together, we found no clear differences in postprandial responses of ED between a protein mix and maltodextrin.

Postprandial CRP levels were found to be significantly higher after ingestion of the protein mix than after ingestion of maltodextrin in the second postprandial study, whereas postprandial levels of LGI Z-scores, SAA and sICAM did not differ after ingestion of the protein mix compared with maltodextrin. In addition, in our first postprandial study, we did not find significant differences in postprandial levels of LGI markers between the protein- and maltodextrin-supplemented meals, which is in accordance with another study comparing postprandial effects of protein and carbohydrate-supplemented breakfasts (19). In conclusion, we found no clear evidence of differences in postprandial LGI between a protein mix and maltodextrin.

Postprandial responses of markers of ED and LGI were also compared between pea protein, milk protein and egg-white protein ingestion in the second postprandial study. Postprandial sICAM levels were lower after pea protein compared to egg-white protein. As a precursor of nitric oxide, the higher arginine content in pea protein $(8.7 \mathrm{~g} / 100 \mathrm{~g})$ compared to milk protein $(3.7 \mathrm{~g} / 100 \mathrm{~g})$ and egg-white protein $(6 \mathrm{~g} / 100 \mathrm{~g})$ might be involved in this, but addition of arginine to amino acid meals (27) or high fat meals (28) was shown not to affect postprandial levels of $\operatorname{sICAM}(27)$ or $\operatorname{vWf}(27,28)$. We found that pea protein 
induced higher postprandial SAA levels compared to egg-white protein and milk protein. Holmer-Jensen et al. (29) also found differences in postprandial inflammation between high fat mixed meals supplemented with different protein sources. Whey protein consumption, which was the most insulinotropic protein source, resulted in lower postprandial CC chemokine ligand-5 concentrations, but the highest postprandial levels of monocyte chemotactic protein 1. Both are markers of inflammation and the authors could not explain the opposing effects of whey protein (29). In our study the most insulinotropic protein (pea protein (22)) also showed opposing effects on postprandial responses of LGI markers (lower sICAM and higher SAA levels) compared to the other protein sources. Whether postprandial insulin levels play a role in postprandial levels of sICAM and SAA remains unclear.

In conclusion, the present study found evidence that fasting ED Z-scores and sICAM levels are lower after 4 weeks on an increased protein diet compared to an increased maltodextrin diet, while fasting levels of biomarkers of LGI do not differ. Both of our postprandial studies indicate no clear evidence of a favorable effect of protein intake compared to maltodextrin intake on postprandial responses of ED and LGI. Postprandial responses of some biomarkers of ED and LGI differed between protein sources, but the importance of these differences is not clear, because overall ED- and LGI-Z-scores did not differ between protein sources. Postprandial responses of ED and LGI to the ingestion of maltodextrin did not differ from those after the ingestion of sucrose.

\section{ACKNOWLEDGEMENTS}

The authors thank Harrie Robins, Jeroen Smets, Sander Offermans, Frank Engel, Thijs Käfer, Floor van den Brand and Imco Janssen for their help with conducting the PROPRES study and second postprandial study. The authors also thank Bas van Bussel for his advice on calculation of the ED and LGI Z-scores.

This study was funded by the Top Institute (TI) Food and Nutrition (project number A1003), Wageningen, The Netherlands. TI Food and Nutrition is a public private partnership of science, industry and government conducting strategic research in food and nutrition (www.tifn.nl). 


\section{REFERENCES}

1. Tielemans SM, Altorf-van der Kuil W, Engberink MF, Brink EJ, van Baak MA, Bakker SJ, et al. Intake of total protein, plant protein and animal protein in relation to blood pressure: a meta-analysis of observational and intervention studies. J Hum Hypertens. 2013;27(9):564-71.

2. Rebholz CM, Friedman EE, Powers LJ, Arroyave WD, He J, Kelly TN. Dietary protein intake and blood pressure: a meta-analysis of randomized controlled trials. Am J Epidemiol. 2012;176 Suppl 7:S27-43.

3. Le Brocq M, Leslie SJ, Milliken P, Megson IL. Endothelial dysfunction: from molecular mechanisms to measurement, clinical implications, and therapeutic opportunities. Antioxid Redox Signal. 2008;10(9):1631-74.

4. Watson T, Goon PK, Lip GY. Endothelial progenitor cells, endothelial dysfunction, inflammation, and oxidative stress in hypertension. Antioxid Redox Signal. 2008;10(6):1079-88.

5. Wong WT, Wong SL, Tian XY, Huang Y. Endothelial dysfunction: the common consequence in diabetes and hypertension. Journal of cardiovascular pharmacology. 2010;55(4):300-7.

6. Lee H, Lee IS, Choue R. Obesity, Inflammation and Diet. Pediatric gastroenterology, hepatology \& nutrition. 2013;16(3):143-52.

7. Landberg R, Naidoo N, van Dam RM. Diet and endothelial function: from individual components to dietary patterns. Curr Opin Lipidol. 2012;23(2):147-55.

8. Lopez-Legarrea P, de la Iglesia R, Abete I, Navas-Carretero S, Martinez JA, Zulet MA. The protein type within a hypocaloric diet affects obesity-related inflammation: The RESMENA project. Nutrition (Burbank, Los Angeles County, Calif). 2014;30(4):424-9.

9. Rebholz CM, Reynolds K, Wofford MR, Chen J, Kelly TN, Mei H, et al. Effect of soybean protein on novel cardiovascular disease risk factors: a randomized controlled trial. Eur J Clin Nutr. 2013;67(1):58-63.

10. Ballard KD, Bruno RS, Seip RL, Quann EE, Volk BM, Freidenreich DJ, et al. Acute ingestion of a novel whey-derived peptide improves vascular endothelial responses in healthy individuals: a randomized, placebo controlled trial. Nutr J. 2009;8:34.

11. Pal S, Ellis V. The chronic effects of whey proteins on blood pressure, vascular function, and inflammatory markers in overweight individuals. Obesity (Silver Spring). 2010;18(7):1354-9.

12. Te Morenga LA, Levers MT, Williams SM, Brown RC, Mann J. Comparison of high protein and high fiber weight-loss diets in women with risk factors for the metabolic syndrome: a randomized trial. Nutr J. 2011;10:40.

13. Esser D, Oosterink E, op 't Roodt J, Henry RM, Stehouwer CD, Muller M, et al. Vascular and inflammatory high fat meal responses in young healthy men; a discriminative role of IL-8 observed in a randomized trial. PLoS One. 2013;8(2):e53474.

14. Esser D, van Dijk SJ, Oosterink E, Muller M, Afman LA. A high-fat SFA, MUFA, or n3 PUFA challenge affects the vascular response and initiates an activated state of cellular adherence in lean and obese middle-aged men. J Nutr. 2013;143(6):843-51.

15. Peairs AD, Rankin JW, Lee YW. Effects of acute ingestion of different fats on oxidative stress and inflammation in overweight and obese adults. Nutr J. 2011;10:122.

16. Derosa G, D'Angelo A, Salvadeo SA, Ferrari I, Fogari E, Gravina A, et al. Oral glucose tolerance test effects on endothelial inflammation markers in healthy subjects and diabetic patients. Horm Metab Res. 2010;42(1):8-13.

17. Nappo F, Esposito K, Cioffi M, Giugliano G, Molinari AM, Paolisso G, et al. Postprandial endothelial activation in healthy subjects and in type 2 diabetic patients: role of fat and carbohydrate meals. $\mathrm{J} \mathrm{Am}$ Coll Cardiol. 2002;39(7):1145-50. 
18. Mah E, Noh SK, Ballard KD, Matos ME, Volek JS, Bruno RS. Postprandial hyperglycemia impairs vascular endothelial function in healthy men by inducing lipid peroxidation and increasing asymmetric dimethylarginine:arginine. J Nutr. 2011;141(11):1961-8.

19. Pal S, Ellis V. Acute effects of whey protein isolate on blood pressure, vascular function and inflammatory markers in overweight postmenopausal women. Br J Nutr. 2011;105(10):1512-9.

20. Teunissen-Beekman KF, Dopheide J, Geleijnse JM, Bakker SJ, Brink EJ, de Leeuw PW, et al. Protein supplementation lowers blood pressure in overweight adults: effect of dietary proteins on blood pressure (PROPRES), a randomized trial. Am J Clin Nutr. 2012;95(4):966-71.

21. Teunissen-Beekman KF, Dopheide J, Geleijnse JM, Bakker SJ, Brink EJ, de Leeuw PW, et al. Blood pressure decreases more after high-carbohydrate meals than after high-protein meals in overweight adults with elevated blood pressure, but there is no difference after 4 weeks of consuming a carbohydrate-rich or protein-rich diet. J Nutr. 2013;143(4):424-9.

22. Teunissen-Beekman KF, Dopheide J, Geleijnse JM, Bakker SJ, Brink EJ, de Leeuw PW, et al. Differential effects of proteins and carbohydrates on postprandial blood pressure-related responses. Br J Nutr. 2014;112:600-8.

23. van Bussel BC, Schouten F, Henry RM, Schalkwijk CG, de Boer MR, Ferreira I, et al. Endothelial dysfunction and low-grade inflammation are associated with greater arterial stiffness over a 6-year period. Hypertension. 2011;58(4):588-95.

24. Ridker PM. Clinical application of C-reactive protein for cardiovascular disease detection and prevention. Circulation. 2003;107(3):363-9.

25. Hirota T, Ohki K, Kawagishi R, Kajimoto Y, Mizuno S, Nakamura Y, et al. Casein hydrolysate containing the antihypertensive tripeptides Val-Pro-Pro and Ile-Pro-Pro improves vascular endothelial function independent of blood pressure-lowering effects: contribution of the inhibitory action of angiotensinconverting enzyme. Hypertens Res. 2007;30(6):489-96.

26. Gogebakan O, Kohl A, Osterhoff MA, van Baak MA, Jebb SA, Papadaki A, et al. Effects of weight loss and long-term weight maintenance with diets varying in protein and glycemic index on cardiovascular risk factors: the diet, obesity, and genes (DiOGenes) study: a randomized, controlled trial. Circulation. 2011;124(25):2829-38.

27. Mariotti F, Huneau JF, Szezepanski I, Petzke KJ, Aggoun Y, Tome D, et al. Meal amino acids with varied levels of arginine do not affect postprandial vascular endothelial function in healthy young men. J Nutr. 2007;137(6):1383-9.

28. Lin CC, Tsai WC, Chen JY, Li YH, Lin LJ, Chen JH. Supplements of L-arginine attenuate the effects of highfat meal on endothelial function and oxidative stress. Int J Cardiol. 2008;127(3):337-41.

29. Holmer-Jensen J, Karhu T, Mortensen LS, Pedersen SB, Herzig KH, Hermansen K. Differential effects of dietary protein sources on postprandial low-grade inflammation after a single high fat meal in obese non-diabetic subjects. Nutr J. 2011;10:115. 



\section{Chapter 7}

\section{Effect of increased protein intake on renal acid load and renal hemodynamic responses}

Submitted

Karianna F.M. Teunissen-Beekman

Janneke Dopheide Johanna M. Geleijnse Stephan J.L. Bakker Elizabeth J. Brink Peter W. de Leeuw Marleen A. van Baak 


\section{ABSTRACT}

Increased protein intake versus maltodextrin intake for 4 weeks lowers blood pressure. Concerns exist that high-protein diets reduce renal function. Effects of acute and longterm protein intake versus maltodextrin intake on renal acid load, glomerular filtration rate and related parameters were compared in this study. Seventy-nine overweight individuals with untreated elevated blood pressure were randomized to consume a protein mix (60 g/day) or maltodextrin ( $60 \mathrm{~g} /$ day) for 4 weeks in energy balance. $24 \mathrm{~h}$ urinary potential renal acid load (UPRAL) was compared between groups. A subgroup (maltodextrin $\mathrm{N}=27$, protein mix $N=25$ ) participated in extra test days investigating fasting levels and postprandial effects of protein- and maltodextrin-supplemented meals on glomerular filtration rate, effective renal plasma flow, plasma renin, aldosterone, $\mathrm{pH}$, and bicarbonate. UPRAL was significantly higher in the protein group after 4 weeks $(P \leq$ 0.001). Postprandial filtration fraction decreased further after the protein-supplemented breakfast than after the maltodextrin-supplemented breakfast after 4 weeks of supplementation $(P \leq 0.001)$. Fasting and postprandial levels of glomerular filtration rate, effective renal plasma flow, renin, aldosterone, angiotensin converting enzyme, $\mathrm{pH}$ and bicarbonate did not differ between groups. In conclusion, no effects were found on renal function after 4 weeks on an increased protein diet (25\% of energy intake), despite an increased renal acid load. Postprandial changes, except for filtration fraction, also did not differ between groups. These data suggest that consumption of a protein mix for 4 weeks causes no harm for the kidneys. 


\section{INTRODUCTION}

Small beneficial health effects of high-protein diets need to be weighed against potential harms (1), like gradual loss of kidney function (2). Among the mechanisms held responsible for the effects of dietary protein on the kidney are hyperfiltration (3) and increased renal acid load $(4,5)$. Previous studies have shown that diets with increased protein content increase glomerular filtration rate (GFR) acutely (6-8) and after chronic consumption (9-11) in individuals with normal kidney function. Increased protein diets are often advised to overweight and obese persons because these diets may reduce adiposity (1). Previously, we reported a blood pressure lowering effect of 4 weeks of increased protein consumption ( $3 \times 20 \mathrm{~g}$ day) compared with 4 weeks of maltodextrin consumption ( $3 \times 20 \mathrm{~g}^{\prime}$ day) in overweight individuals with mild blood pressure elevation (12). Because overweight and obese persons often have elevated blood pressure (13), this may be an extra benefit from consuming a high-protein diet for this group. We investigated GFR and acid load in response to $a \approx 10 \%$ increase in protein intake. Chronic and postprandial responses of renal acid load, renal hemodynamics, renal function parameters, and the renin-angiotensin-aldosterone system were compared between protein- and maltodextrin-supplemented diets $(12,14)$. We hypothesized that the renal acid load and fasting GFR would be higher on the protein-supplemented diet than on the maltodextrinsupplemented diet and that the protein-supplemented breakfast would induce a greater postprandial increase in GFR and effective renal plasma flow (ERPF) than the maltodextrin-supplemented breakfast both at the start and at the end of the 4-week diet intervention. Because the kidneys are involved in blood pressure regulation, postprandial changes in renin and aldosterone were also measured. Angiotensin converting enzyme (ACE) activity was studied, because (milk)proteins are hypothesized to reduce blood pressure via ACE inhibition (15).

\section{METHODS}

This randomized trial on the effects of protein on blood pressure (PROPRES) has been described previously $(12,14)$. PROPRES was a randomized, double blind, parallel group trial comparing the effects of 4 weeks $3 \times 20 \mathrm{~g} /$ day protein supplementation (protein intake $\approx 25 \%$ of energy) with isocaloric maltodextrin supplementation ( $3 \times 20 \mathrm{~g} /$ day; protein intake $\approx 15 \%$ of energy) on blood pressure. All 94 participants followed a standard dietary advice from 2 weeks before the start of the study until the end of the supplementation period and remained in energy balance. Postprandial renal and humoral responses to proteinand maltodextrin-supplemented meals were compared in a subgroup ( $N=52)$ of the PROPRES study on day 1 and after 4 weeks of supplementation. The study was approved by the local medical ethical committee of Maastricht University Medical Centre. All 
participants gave written informed consent. Inclusion and exclusion criteria and the method of randomization are described elsewhere $(12,14)$.

\section{Test days}

Participants attended test days on day 1 and after 4 weeks of supplementation for measurements of variables in the fasting state and in response to protein- or maltodextrin-supplemented meals. Meals were supplemented with $20 \mathrm{~g}$ of a protein mix (40\% plant protein and $60 \%$ animal protein) or $20 \mathrm{~g}$ maltodextrin. Renal hemodynamic responses were measured at 30, 60, 90, 120, 180 and $240 \mathrm{~min}$ after breakfast. Postprandial changes in active renin, ACE and aldosterone were also measured during $4 \mathrm{~h}$ after breakfast and were continued for 8 more hours at 300, 360, 420, 480, 540, 600, 660, $720 \mathrm{~min}$. Lunch and dinner were consumed after 4 and 8 hours. Further details on measurements and on the composition of the meals and supplements can be found elsewhere $(12,14)$.

\section{Renal hemodynamic responses}

After participants arrived at the university a catheter was inserted in the left and right antecubital vein and retrogradely in a dorsal vein of the right hand. The right hand was heated in a hot box in order to arterialize the blood in the hand vein. For determination of GFR and ERPF, inulin (Inutest 25\%, Fresenius Kabi, Graz, Austria) and para-aminohippurate (PAH, MSD, Haarlem, Netherlands) were continuously infused in the right arm vein and blood was drawn from the left arm vein (16).

Filtration fraction (FF) was calculated as GFR/ ERPF. Renal blood flow (RBF) was calculated as ERPF /(1-hematocrit). Hematocrit was measured with a microhematocrit reader. Renal vascular resistance (RVR) was calculated from RBF and MAP as: MAP/RBF. Measurements of blood pressure can be found elsewhere (14).

\section{Renin, ACE, aldosterone}

Aldosterone and renin were analyzed in EDTA-plasma and ACE was analyzed in serum. Analyses were done by MLM medical labs (Mönchengladbach, Germany). ACE activity was determined with the ACE-color method (Fujirebio, Tokyo, Japan). Renin was measured with the LIAISON Direct renin assay using chemiluminescent immunoassay technology (Diasorin, Saluggia, Italy). Aldosterone was measured with an ELISA (IBL international GMBH, Hamburg, Germany).

\section{Acid load and urinary excretions}

Blood $\mathrm{pH}$ and bicarbonate concentration were measured in arterialized blood with a blood gas analyzer (ABL 510, Radiometer Medical A/S, Copenhagen, Denmark). 
Renal acid load was determined by calculating the $24 \mathrm{~h}$ urinary potential renal acid load (UPRAL) as follows:

uPRAL $(\mathrm{mEq} /$ day $)=\left(\mathrm{Cl}(\mathrm{mmol} /\right.$ day $)+\mathrm{SO}_{4}(\mathrm{mmol} /$ day $) * 2+\mathrm{PO}_{4}(\mathrm{mmol} /$ day $\left.) * 1.8\right)-(\mathrm{Na}$ $(\mathrm{mmol} /$ day $)+K(\mathrm{mmol} /$ day $)+\mathrm{Mg}(\mathrm{mmol} /$ day $) * 2+\mathrm{Ca}(\mathrm{mmol} /$ day $) * 2)(17)$

$24 \mathrm{~h}$ urinary excretions of electrolytes, sulfate and phosphate are reported elsewhere (12). $24 \mathrm{~h}$ urinary excretion of ammonium was measured chromatographically (Alliance HT 2795; Waters, Milford, MA). Ammonium and ammonia play an important role in the elimination of acid from the body (18).

\section{Statistical analyses}

Baseline characteristics and fasting values of all variables were tested with an independent samples $\mathrm{t}$ test. Changes in fasting variables, UPRAL and $24 \mathrm{~h}$ urinary ammonium after 4 weeks of supplementation were compared between groups with an univariate ANCOVA with baseline measurements as a covariate. To control for errors introduced by incorrect $24 \mathrm{~h}$ urine collection, UPRAL and $24 \mathrm{~h}$ urinary ammonium were also analyzed when including only participants who had a change $<20 \%$ of $24 \mathrm{~h}$ urinary creatinine during the intervention (19).

Postprandial data on each test day were analyzed by a linear mixed-model analysis using a random intercept model. Analyses started off with the full model including group, time, fasting measurement, BMI, age and sex. BMI, age and sex were removed from the model one-by-one starting with the least significant covariate to test whether they significantly contributed to the model with a -2 log likelihood test. Significant covariates were kept in the final model. Aldosterone and renin were naturally log-transformed before analyses because of their non-normal distributions.

Incremental areas under the curve (iAUCs) were calculated and tested for deviance from zero with a one-sample $t$ test to see whether postprandial increases/decreases were significant.

All statistical analyses were performed with SPSS software (version 20; IBM). A $P$ value of $<0.05$ was considered significant.

\section{RESULTS}

From the 94 PROPRES participants, 79 were included in the present analyses because UPRAL could not be calculated in some participants due to missing electrolyte concentrations. Baseline characteristics of 43 participants in the maltodextrin group and 36 participants in the protein group included in analyses are shown in table 1 . Baseline characteristics of the total group and the subgroup participating in the postprandial tests were described previously $(12,14)$. 
Table 1. Baseline characteristics

\begin{tabular}{lccc}
\hline & Maltodextrin group & Protein group & $P$-value \\
\hline Gender (m/f) & $30 / 13$ & $25 / 11$ & - \\
Age (y) & $55 \pm 1$ & $55 \pm 1$ & 0.83 \\
BMI (kg.m $\left.{ }^{-2}\right)$ & $29 \pm 0.5$ & $28 \pm 0.4$ & 0.10 \\
SBP (mmHg) & $143 \pm 2$ & $143 \pm 2$ & 0.90 \\
DBP (mmHg) & $92 \pm 1$ & $93 \pm 1$ & 0.80 \\
\hline
\end{tabular}

Values are mean \pm SEM. Between-group differences were tested with an independent-samples t test. DBP, diastolic blood pressure; SBP, systolic blood pressure.

Table 2. Fasting renal hemodynamics, hormones and measures of systemic acidity

\begin{tabular}{|c|c|c|c|c|c|c|}
\hline & \multicolumn{3}{|c|}{ Maltodextrin } & \multicolumn{3}{|c|}{ Protein } \\
\hline & day 1 & 4 weeks & $\mathbf{N}$ & day 1 & 4 weeks & $\mathbf{N}$ \\
\hline Body surface area $\left(\mathrm{m}^{2}\right)$ & $2.0 \pm 0.0$ & & 27 & $2.0 \pm 0.0$ & & 25 \\
\hline $\operatorname{ERPF}\left(\mathrm{mL} \cdot \mathrm{min}^{-1}\right)$ & $440 \pm 21$ & $437 \pm 20$ & 24 & $433 \pm 17$ & $412 \pm 15$ & 24 \\
\hline $\mathrm{GFR}\left(\mathrm{mL} \cdot \mathrm{min}^{-1}\right)$ & $137 \pm 5$ & $134 \pm 5$ & 24 & $130 \pm 5$ & $127 \pm 5$ & 24 \\
\hline $\mathrm{FF}$ & $0.32 \pm 0.01$ & $0.31 \pm 0.01$ & 24 & $0.30 \pm 0.01$ & $0.32 \pm 0.01$ & 24 \\
\hline $\mathrm{RBF}\left(\mathrm{mL} \cdot \mathrm{min}^{-1}\right)$ & $788 \pm 36$ & $763 \pm 39$ & 23 & $785 \pm 34$ & $710 \pm 28$ & 23 \\
\hline $\mathrm{RVR}\left(\mathrm{mmHg} \cdot \min \cdot \mathrm{mL}^{-1}\right)$ & $0.15 \pm 0.01$ & $0.15 \pm 0.01$ & 24 & $0.14 \pm 0.01$ & $0.15 \pm 0.01$ & 24 \\
\hline $\operatorname{Renin}\left(\mathrm{pmol} \cdot \mathrm{L}^{-1}\right)$ & $0.54 \pm 0.06^{*}$ & $0.52 \pm 0.08$ & 25 & $0.85 \pm 0.12^{*}$ & $0.75 \pm 0.09$ & 25 \\
\hline $\operatorname{ACE}\left(U \cdot L^{-1}\right)$ & $16 \pm 1$ & $16 \pm 1$ & 26 & $15 \pm 1$ & $14 \pm 1$ & 25 \\
\hline Aldosterone $\left(\mathrm{nmol} \cdot \mathrm{L}^{-1}\right)$ & $0.38 \pm 0.02$ & $0.37 \pm 0.03$ & 27 & $0.45 \pm 0.07$ & $0.40 \pm 0.05$ & 25 \\
\hline $\mathrm{pH}$ & $7.41 \pm 0.00$ & $7.40 \pm 0.00$ & 25 & $7.41 \pm 0.00$ & $7.41 \pm 0.00$ & 25 \\
\hline $\mathrm{HCO}_{3}\left(\mathrm{mmol} \cdot \mathrm{L}^{-1}\right)$ & $24 \pm 1$ & $25 \pm 1$ & 25 & $25 \pm 1$ & $25 \pm 1$ & 25 \\
\hline
\end{tabular}

Values are mean \pm SEM. ${ }^{*} \mathrm{P}<0.05$ for between-group differences. Between-group differences on day 1 were tested with an independent samples t-test. Between-group differences after 4 weeks were tested with ANCOVA correcting for the fasting value on day 1. ERPF, effective renal plasma flow; FF, filtration fraction; GFR, glomerular filtration rate; RBF, renal blood flow; RVR, renal vascular resistance.

\section{Renal hemodynamic responses}

Fasting renal hemodynamic values did not differ between groups at baseline and after 4 weeks of supplementation (table 2). Food intake increased ERPF and RBF, and decreased FF and RVR (iAUC, $P \leq 0.05$ ), whereas the iAUC of the postprandial GFR did not differ from zero. Postprandial responses of ERPF, GFR, RBF and RVR did not differ between groups on either test day (figure $1 \mathrm{~A}-\mathrm{H}$ ). Postprandial FF remained significantly higher after the maltodextrin-supplemented breakfast than after the protein-supplemented breakfast after 4 weeks of supplementation (figure 1F). 

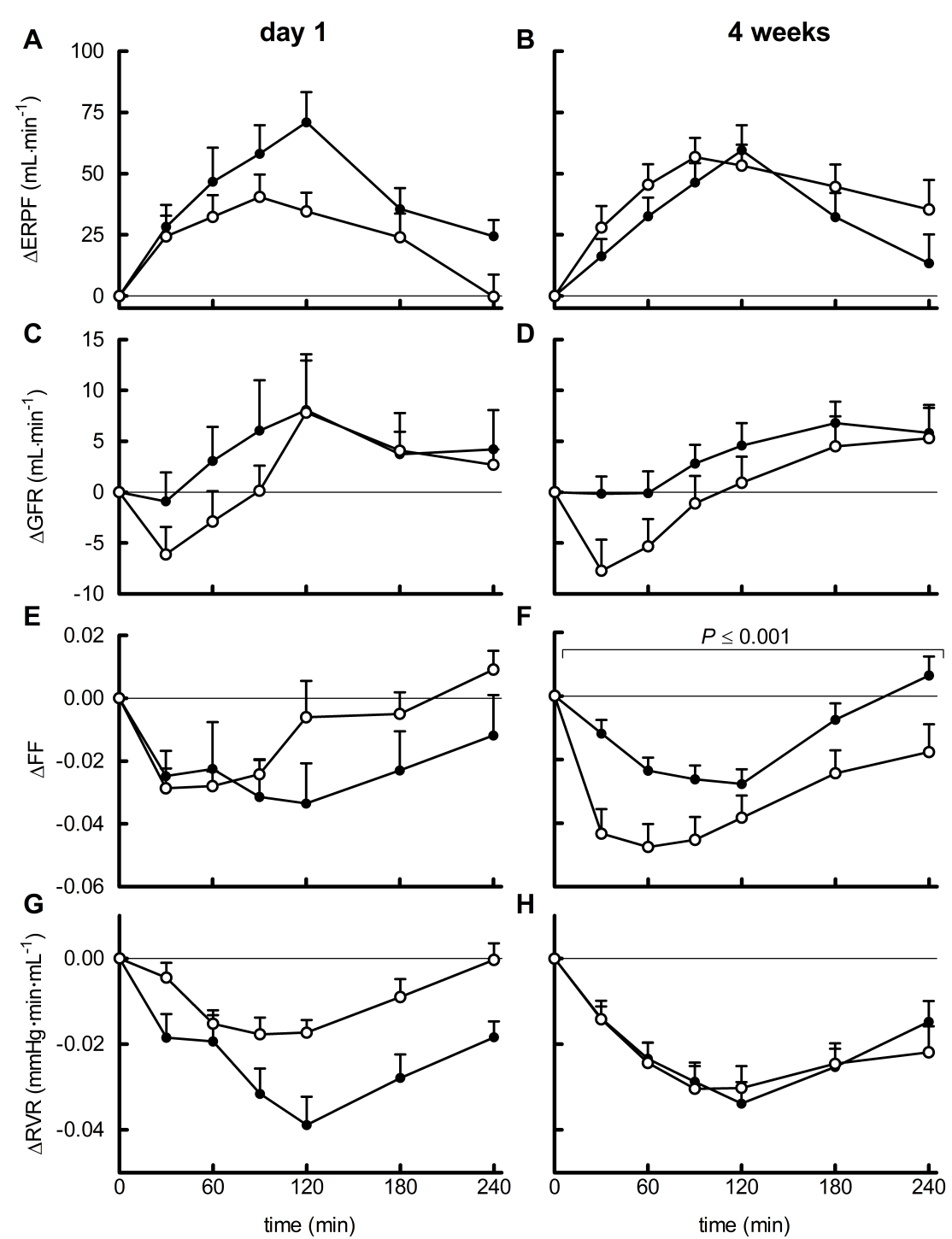

Figure 1. Mean ( \pm SEM) of 4 h postprandial responses of renal function to breakfasts supplemented with protein or maltodextrin on day 1 of supplementation (left) and after 4 weeks of supplementation (right). Panels are $\operatorname{ERPF}(A, B), \operatorname{GFR}(C, D), \operatorname{FF}(E, F)$, and RVR (G, H). On day 1 ERPF, GFR and FF $n=25$ maltodextrin group, $n=25$ protein group; RVR $n=24$ maltodextrin group, $n=24$ protein group. After 4 weeks ERPF, GFR, FF, and RVR $n=26$ maltodextrin group, $n=24$ protein group.

* $\mathrm{P}<0.05$ for the difference between maltodextrin group (black) and protein group (white) over the whole $4 \mathrm{~h}$ period according to the mixed model. ERPF, effective renal plasma flow; FF, filtration fraction; GFR, glomerular filtration rate; RVR, renal vascular resistance. 

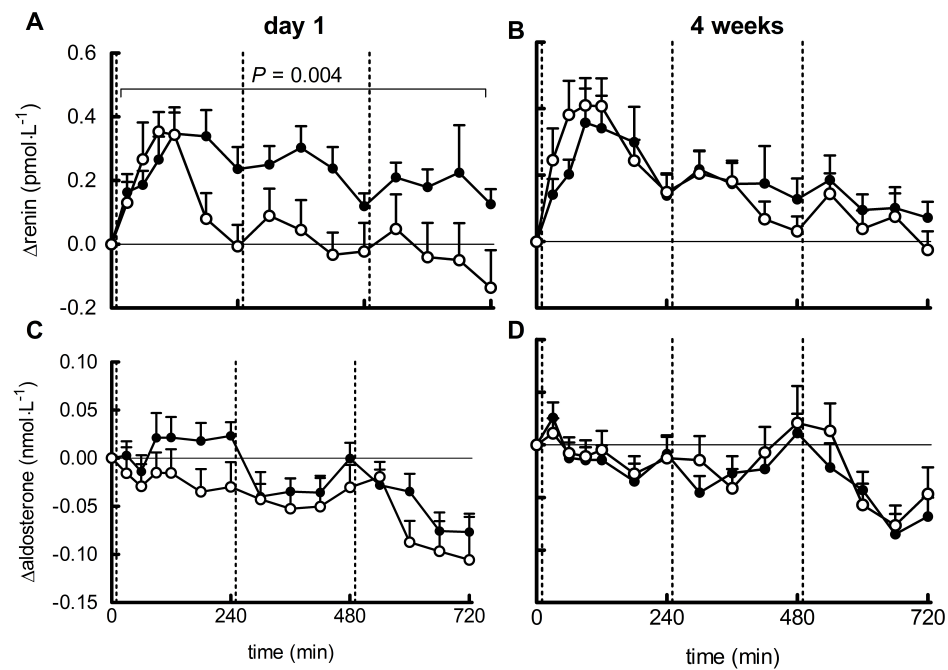

Figure 2. Mean ( \pm SEM) of $12 \mathrm{~h}$ postprandial responses of renin-angiotensin-aldosterone system to meals supplemented with protein or maltodextrin on day 1 of supplementation (left) and after 4 weeks of supplementation (right). Panels are renin (A, B) and aldosterone (C, D). On day 1 renin $n=25$ maltodextrin group, $n=25$ protein group; aldosterone $n=27$ maltodextrin group, $n=25$ protein group. After 4 weeks renin and aldosterone $n=27$ maltodextrin group, $n=25$ protein group. Vertical lines indicate breakfast, lunch, and dinner. ${ }^{*} \mathrm{P}<0.05$ for the difference between maltodextrin group (black) and protein group (white) over the whole $12 \mathrm{~h}$ period according to the mixed model.
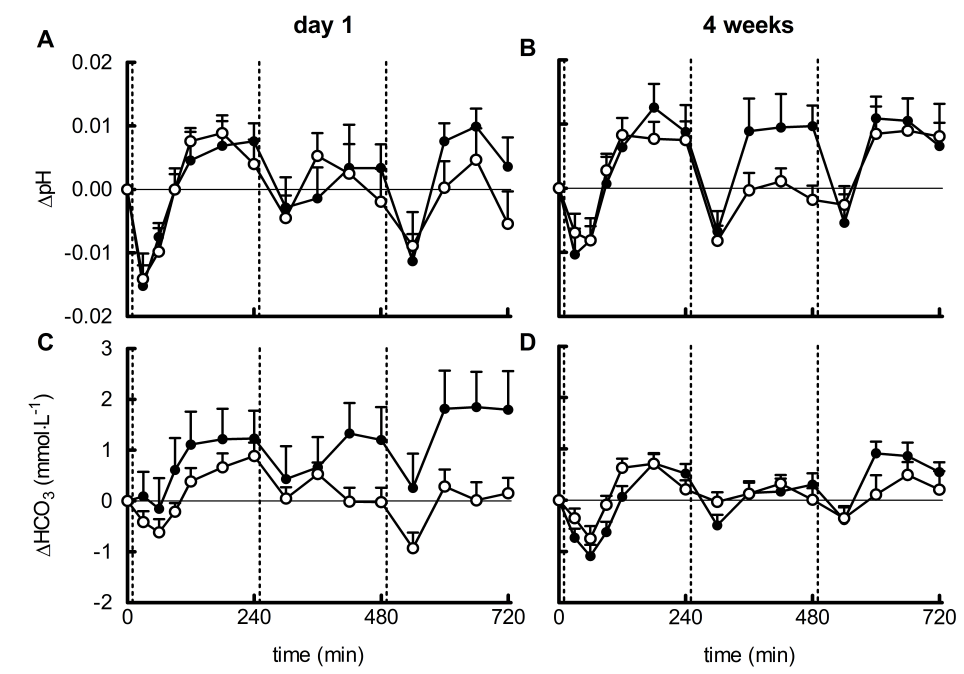

Figure 3. Mean ( \pm SEM) of $12 \mathrm{~h}$ postprandial responses of blood $\mathrm{pH}$ and bicarbonate to meals supplemented with protein or maltodextrin on day 1 of supplementation (left) and after 4 weeks of supplementation (right). Panels are pH (A, B) and bicarbonate (C, D). On day 1 and after 4 weeks pH and bicarbonate $n=26$ maltodextrin group, $n=25$ protein group. Vertical lines indicate breakfast, lunch, and dinner. Postprandial responses did not differ between the maltodextrin group (black) and protein group (white) according to the mixed model. 


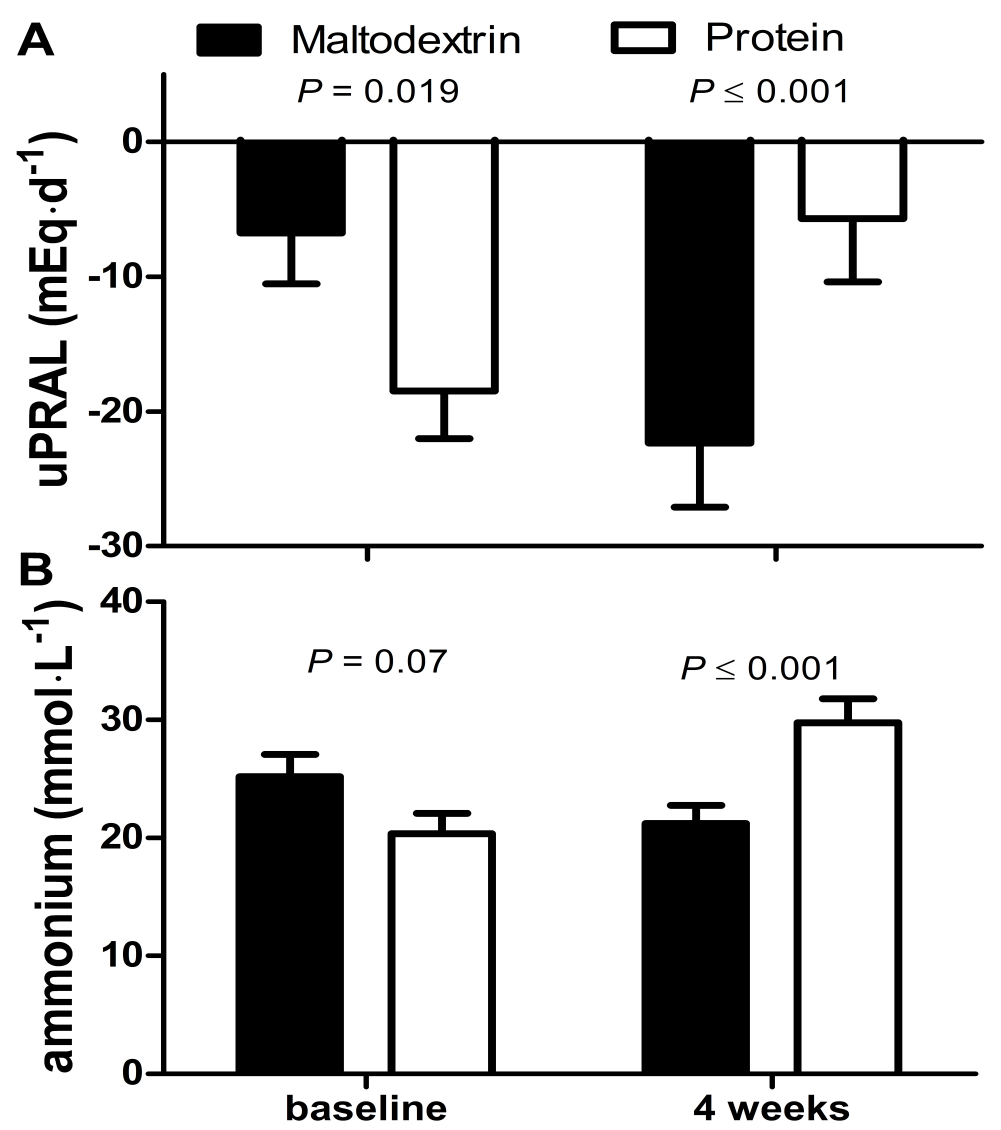

Figure 4. Mean ( \pm SEM) of $24 \mathrm{~h}$ uPRAL (panel A) and ammonium excretion (panel B) at baseline and after 4 weeks of supplementation in the protein group (white) and maltodextrin group (black). For uPRAL: baseline $\mathrm{n}=41$ maltodextrin group, $\mathrm{n}=35$ protein group. After 4 weeks $\mathrm{n}=38$ maltodextrin group, $\mathrm{n}=35$ protein group. For ammonium: baseline $n=43$ maltodextrin group, $n=35$ protein group. After 4 weeks $n=39$ maltodextrin group, $n=35$ protein group. Between-group differences on day 1 were tested with an independent samples t-test. Between-group differences after 4 weeks were tested with ANCOVA correcting for the fasting value on day 1. uPRAL, urinary potential renal acid load.

\section{Renin, aldosterone, $A C E$}

Baseline renin was significantly lower in the maltodextrin group compared with the protein group (table 2). Twelve-hour postprandial renin was increased after the maltodextrin-supplemented breakfast on day 1 and after both breakfasts at 4 weeks (iAUC, $P \leq 0.05$ ). Postprandial renin was higher in the maltodextrin group than in the protein group at day 1 of supplementation, but not after 4 weeks (figure 2A-B). ACE (data not shown) and aldosterone (figure $2 \mathrm{C}-\mathrm{D}$ ) decreased similarly in both groups on both test days (iAUC, $P \leq 0.05$ ). 


\section{Acid load}

Fasting and postprandial plasma $\mathrm{pH}$ and bicarbonate did not differ between groups. (figure 3A-D), and the iAUCs did not significantly differ from zero. Baseline UPRAL was significantly lower in the protein group compared with the maltodextrin group, whereas baseline-corrected UPRAL after 4 weeks was significantly higher in the protein group compared with the maltodextrin group (figure 4A). Ammonium excretion was also significantly higher in the protein group after 4 weeks(figure $4 \mathrm{~B}$ ). When only participants with $<20 \%$ change in $24 \mathrm{~h}$-urinary creatinine were analyzed (maltodextrin group $\mathrm{N}=27$, protein group $\mathrm{N}=29$ ), baseline UPRAL no longer differed between groups, whereas differences in baseline-corrected UPRAL and ammonium after 4 weeks sustained.

\section{DISCUSSION}

In contrast to our hypothesis, fasting GFR and other variables of renal hemodynamics did not differ between the protein and maltodextrin group after 4 weeks of supplementation. Therefore, the present study revealed no indication that GFR would be adversely affected by consumption of $60 \mathrm{~g}$ protein extra per day for 4 weeks. Increased protein consumption has been reported to increase fasting GFR in energy-balanced diets $(9,10)$. In one study GFR and FF increased in healthy young men after 7 days on a high-protein diet (181g protein/day) versus a normal protein diet (88g protein/day)(9). In the Omniheart trial, 6 weeks on an increased protein diet ( $+10 \%$ of energy from protein) increased fasting GFR compared to diets replacing protein with either carbohydrate or fat in individuals with untreated elevated blood pressure (10). High-protein weight-loss diets also increased fasting GFR $(11,20)$. An explanation why the present study did not find an increase in fasting GFR could be because we increased protein intake with protein isolate, while others used protein-rich foods $(9-11,20)$. Also, participants in three of these studies had lower baseline GFR $(10,11,20)$ compared to our participants. Participants in one study had a similar baseline GFR (9) as those in our study, however the contrast in protein intake was higher than in our study (93 g/day versus $60 \mathrm{~g} /$ day) (9), and the extra protein consisted mainly of animal protein (9), while we used $60 \%$ animal protein and $40 \%$ plant protein. Plant protein may have a smaller or no effect on GFR. In a crossover trial, consumption of bread containing $80 \mathrm{~g} /$ day of wheat gluten versus $93 \mathrm{~g} / \mathrm{day}$ of carbohydrates for one month showed no differences in creatinine clearance in individuals with hyperlipidemia (21), whereas a crossover study comparing 4 weeks of animal protein consumption with plant protein consumption found higher GFR and ERPF after the animal protein diet in type 1 diabetic patients (22). 
Changes in UPRAL and ammonium excretion showed that, renal acid load was increased in the protein group after 4 weeks, whereas fasting blood $\mathrm{pH}$ and bicarbonate did not differ between groups. This suggests no disturbances in systemic acid-base balance by the highprotein diet. Associations between protein intake and renal acid load have been reported (23), and it has been suggested that increased renal excretion of ammonia and acids might lead to tubulointerstitial injury and decreased kidney function in the long term (4). The present study found no adverse effects of 4 weeks of increased protein intake on kidney function. In addition, albumin excretion was borderline significantly lower in the protein group compared to the maltodextrin group (12). Whether protein intake-induced hyperfiltration and/or renal acid load will lead, in the longer term, to disturbances in renal function remains unclear. Six months on a high-protein (25\% of energy from protein) weight-loss diet was found to increase GFR without adverse changes in albuminuria (11). Two years on a low-carbohydrate high-protein diet (22\% of energy from protein) was found to improve GFR and urinary microalbumin-to-creatinine ratios to the same extent as a Mediterranean diet and a low fat diet (19\% of energy from protein) (20). Another two year weight-loss study found no effects on GFR or albuminuria of a low-carbohydrate high-protein diet (24). This suggests that, high-protein diets do not adversely affect kidney function in individuals with normal kidney function over a period of 2 years, although effects on the longer term still cannot be excluded. In type 2 diabetic patients with early renal disease, one year on a moderate-protein weight-loss diet (110 g protein/day) compared with a standard protein diet (97 g protein/day) was not harmful for kidney function (25).

In contrast to our second hypothesis, postprandial responses of GFR and ERPF did not differ after the protein- and maltodextrin-supplemented meals. Also, GFR did not increase significantly after the protein-supplemented breakfast and only exceeded baseline levels from 90-120 minutes after breakfast. This increase may be too late to be picked up by iAUC analyses. Many studies have reported that protein-induced increases of postprandial GFR and $\operatorname{ERPF}(7,8,26,27)$. Two of these studies did not report AUCs, but found a significant increase in GFR and ERPF by comparing separate time points with baseline measurements (7) or with a control condition (27). Another potential explanation for the lack of such effect in the present study is the relatively low dose of protein consumed. Studies that reported increases in GFR gave $70-90 \mathrm{~g}$ of protein $(7,8,26,28)$, whereas the protein content of the protein-supplemented breakfast in our study was $43 \mathrm{~g}$. Differences in protein sources tested may also lead to different outcomes. Egg-white protein, cheese, tofu and soy were found to have no acute effects on $\operatorname{GFR}$ and $\operatorname{ERPF}(28,29)$, whereas meat or tuna increased GFR (7, 8, 26-29). The sulfur-containing amino acids methionine and cysteine could play a role in the increased GFR after meat and tuna intake (30). However, 
the protein mix in the present study also contained a considerable amount of methionine and cysteine, which is reflected in increased urinary sulphate excretion in the protein group during the test days (data not shown) and after 4 weeks of supplementation (12). Meal consumption increased ERPF in our study, with no difference between meals. This increase in ERPF was accompanied by a decrease in RVR and parallels the decrease in blood pressure and total peripheral resistance reported earlier (14). Thus increased regional blood flow in the kidneys partly contributed to the postprandial decrease in blood pressure and total peripheral resistance.

On the first day of supplementation, but not after 4 weeks, renin increased to a higher level after the maltodextrin-supplemented breakfast. The meal-induced increase in renin could be a homeostatic response to the meal-induced decrease in blood pressure, which was previously reported (14). This idea is strengthened by the finding that renin was significantly higher in the maltodextrin group on day 1 , when blood pressure was significantly lower (14), whereas postprandial responses of renin and blood pressure did not differ after 4 weeks (14). Higher postprandial renin levels could be a result of the higher insulin response (31) in the maltodextrin group (14). However, postprandial renin no longer differed between groups after 4 weeks of supplementation despite higher postprandial insulin in the maltodextrin group, which makes this explanation less likely. In addition, we found no between-group differences in RBF response on either test day, which contrasts with findings on insulin-induced renal vasodilation (31). Aldosterone, decreased below baseline during the day but showed no clear meal-induced responses. This postprandial change could reflect the circadian rhythm of aldosterone, which peaks at 0600 and then lowers during the day until 00:00 (32). Consumption of beef containing 1 $\mathrm{g} / \mathrm{kg}$ bodyweight of protein was found to increase aldosterone after two hours (33), but our protein dose was much smaller.

In conclusion, this study shows that increasing protein intake to $\approx 25 \%$ of energy for 4 weeks increases the systemic acid load compared to maltodextrin intake, with no evidence for adverse effects on kidney function in healthy obese individuals with mildly elevated blood pressure. 


\section{ACKNOWLEDGEMENTS}

This publication has been realized with the support of MSD (gift of PAH). The views expressed in this publication are those expressed by the authors and do not necessarily reflect those of MSD. The authors thank Harrie Robins, Jeroen Smets, Sander Offermans and Frank Engel for their help in the PROPRES trial. The authors also thank Jet Bost for assessing plasma PAH and inulin levels.

This study was funded by the Top Institute (TI) Food and Nutrition (project number A1003), Wageningen, The Netherlands. TI Food and Nutrition is a public private partnership of science, industry and government conducting strategic research in food and nutrition (www.tifn.nl). 


\section{REFERENCES}

1. Santesso N, Akl EA, Bianchi M, Mente A, Mustafa R, Heels-Ansdell D, et al. Effects of higher- versus lower-protein diets on health outcomes: a systematic review and meta-analysis. Eur J Clin Nutr. 2012;66(7):780-8.

2. Martin WF, Armstrong LE, Rodriguez NR. Dietary protein intake and renal function. Nutr Metab (Lond). 2005;2:25.

3. Palatini P. Glomerular hyperfiltration: a marker of early renal damage in pre-diabetes and prehypertension. Nephrol Dial Transplant. 2012;27(5):1708-14.

4. van den Berg E, Hospers FA, Navis G, Engberink MF, Brink EJ, Geleijnse JM, et al. Dietary acid load and rapid progression to end-stage renal disease of diabetic nephropathy in Westernized South Asian people. J Nephrol. 2011;24(1):11-7.

5. Goraya N, Wesson DE. Dietary management of chronic kidney disease: protein restriction and beyond. Curr Opin Nephrol Hypertens. 2012;21(6):635-40.

6. Chan AY, Cheng ML, Keil LC, Myers BD. Functional response of healthy and diseased glomeruli to a large, protein-rich meal. J Clin Invest. 1988;81(1):245-54.

7. Viberti G, Bognetti E, Wiseman MJ, Dodds R, Gross JL, Keen H. Effect of protein-restricted diet on renal response to a meat meal in humans. Am J Physiol. 1987;253(3 Pt 2):F388-93.

8. Simon AH, Lima PR, Almerinda M, Alves VF, Bottini PV, de Faria JB. Renal haemodynamic responses to a chicken or beef meal in normal individuals. Nephrol Dial Transplant. 1998;13(9):2261-4.

9. Frank H, Graf J, Amann-Gassner U, Bratke R, Daniel H, Heemann U, et al. Effect of short-term highprotein compared with normal-protein diets on renal hemodynamics and associated variables in healthy young men. Am J Clin Nutr. 2009;90(6):1509-16.

10. Juraschek SP, Appel LJ, Anderson CA, Miller ER, 3rd. Effect of a high-protein diet on kidney function in healthy adults: results from the OmniHeart trial. Am J Kidney Dis. 2013;61(4):547-54.

11. Skov AR, Toubro S, Bulow J, Krabbe K, Parving HH, Astrup A. Changes in renal function during weight loss induced by high vs low-protein low-fat diets in overweight subjects. Int J Obes Relat Metab Disord. 1999;23(11):1170-7.

12. Teunissen-Beekman KF, Dopheide J, Geleijnse JM, Bakker SJ, Brink EJ, de Leeuw PW, et al. Protein supplementation lowers blood pressure in overweight adults: effect of dietary proteins on blood pressure (PROPRES), a randomized trial. Am J Clin Nutr. 2012;95(4):966-71.

13. Kang YS. Obesity Associated Hypertension: New Insights into Mechanism. Electrolyte \& blood pressure : E \& BP. 2013;11(2):46-52.

14. Teunissen-Beekman KF, Dopheide J, Geleijnse JM, Bakker SJ, Brink EJ, de Leeuw PW, et al. Blood pressure decreases more after high-carbohydrate meals than after high-protein meals in overweight adults with elevated blood pressure, but there is no difference after 4 weeks of consuming a carbohydrate-rich or protein-rich diet. J Nutr. 2013;143(4):424-9.

15. McGregor RA, Poppitt SD. Milk protein for improved metabolic health: a review of the evidence. Nutr Metab (Lond). 2013;10(1):46.

16. van der Zander K, Houben AJ, Webb DJ, Udo E, Kietselaer B, Hofstra L, et al. Selective endothelin B receptor blockade does not influence BNP-induced natriuresis in man. Kidney Int. 2006;69(5):864-8.

17. Krupp D, Shi L, Remer T. Longitudinal relationships between diet-dependent renal acid load and blood pressure development in healthy children. Kidney Int. 2013.

18. Garibotto G, Verzola D, Sofia A, Saffioti S, Menesi F, Vigo E, et al. Mechanisms of renal ammonia production and protein turnover. Metabolic brain disease. 2009;24(1):159-67.

19. Stuveling EM, Bakker SJ, Hillege HL, Burgerhof JG, de Jong PE, Gans RO, et al. C-reactive protein modifies the relationship between blood pressure and microalbuminuria. Hypertension. 2004;43(4):791-6.

20. Tirosh A, Golan R, Harman-Boehm I, Henkin Y, Schwarzfuchs D, Rudich A, et al. Renal function following three distinct weight loss dietary strategies during 2 years of a randomized controlled trial. Diabetes Care. 2013;36(8):2225-32.

21. Jenkins DJ, Kendall CW, Vidgen E, Augustin LS, van Erk M, Geelen A, et al. High-protein diets in hyperlipidemia: effect of wheat gluten on serum lipids, uric acid, and renal function. Am J Clin Nutr. 2001;74(1):57-63.

22. Kontessis PA, Bossinakou I, Sarika L, Iliopoulou E, Papantoniou A, Trevisan R, et al. Renal, metabolic, and hormonal responses to proteins of different origin in normotensive, nonproteinuric type I diabetic patients. Diabetes Care. 1995;18(9):1233. 
23. Remer T, Manz F. Estimation of the renal net acid excretion by adults consuming diets containing variable amounts of protein. Am J Clin Nutr. 1994;59(6):1356-61.

24. Friedman AN, Ogden LG, Foster GD, Klein S, Stein R, Miller B, et al. Comparative effects of lowcarbohydrate high-protein versus low-fat diets on the kidney. Clin J Am Soc Nephrol. 2012;7(7):1103-11.

25. Jesudason DR, Pedersen E, Clifton PM. Weight-loss diets in people with type 2 diabetes and renal disease: a randomized controlled trial of the effect of different dietary protein amounts. Am J Clin Nutr. 2013;98(2):494-501.

26. Bosch JP, Lew S, Glabman S, Lauer A. Renal hemodynamic changes in humans. Response to protein loading in normal and diseased kidneys. Am J Med. 1986;81(5):809-15.

27. Hostetter TH. Human renal response to meat meal. Am J Physiol. 1986;250(4 Pt 2):F613-8.

28. Kontessis P, Jones S, Dodds R, Trevisan R, Nosadini R, Fioretto P, et al. Renal, metabolic and hormonal responses to ingestion of animal and vegetable proteins. Kidney Int. 1990;38(1):136-44.

29. Nakamura H, Yamazaki M, Chiba Y, Tamura N, Momotsu T, Ito S, et al. Glomerular filtration response to acute loading with protein from different sources in healthy volunteers and diabetic patients. The Tohoku journal of experimental medicine. 1990;162(3):269-78.

30. Brosnan JT, Brosnan ME. The sulfur-containing amino acids: an overview. J Nutr. 2006;136(6 Suppl):1636S-40S.

31. Perlstein TS, Gerhard-Herman M, Hollenberg NK, Williams GH, Thomas A. Insulin induces renal vasodilation, increases plasma renin activity, and sensitizes the renal vasculature to angiotensin receptor blockade in healthy subjects. J Am Soc Nephrol. 2007;18(3):944-51.

32. Hurwitz S, Cohen RJ, Williams GH. Diurnal variation of aldosterone and plasma renin activity: timing relation to melatonin and cortisol and consistency after prolonged bed rest. Journal of applied physiology (Bethesda, Md : 1985). 2004;96(4):1406-14.

33. Krishna GG, Newell G, Miller E, Heeger P, Smith R, Polansky M, et al. Protein-induced glomerular hyperfiltration: role of hormonal factors. Kidney Int. 1988;33(2):578-83. 



\section{Chapter 8}

General discussion 
This thesis aimed to answer two questions. The first was: "Does protein intake affect blood pressure (BP)?" and the second was: "Do dietary proteins influence BP by affecting sympathetic nervous system (SNS) activity, humoral mechanisms, endothelial function, the renin-angiotensin-aldosterone system (RAAS), and/or kidney function?" In chapter 2 these questions were reviewed based on the most recent literature. Chapter $\mathbf{3}$ describes the findings of a 4-week randomized controlled trial, which compared the effects of 60 g/day dietary proteins versus $60 \mathrm{~g} /$ day maltodextrin on BP. Chapters 4 and 6 describe postprandial studies aimed to explore mechanisms by which dietary proteins affect BP, compared to maltodextrin. In chapters 5 and $\mathbf{6}$ postprandial effects of protein isolates from different sources (pea, milk, egg white) on BP and BP regulation mechanisms were tested to explore whether protein sources have different effects on BP and through which mechanisms. Chapter 7 describes the effects of 4 weeks increased protein intake and of protein-enriched meals on kidney function.

\section{DOES PROTEIN INTAKE AFFECT BLOOD PRESSURE?}

In our 4-week randomized trial, we found a reduction in BP of $-4.9 \mathrm{mmHg}$ systolic blood pressure (SBP) and $-2.7 \mathrm{mmHg}$ diastolic blood pressure (DBP) after consumption of the protein mix compared to maltodextrin (Chapter 3 ). This confirms the findings from recent meta-analyses that exchanging dietary carbohydrates for dietary proteins is beneficial for BP $(1,2)$. Strongest evidence for a BP lowering effect by dietary proteins comes from randomized controlled trials because food intake can be controlled better than in observational studies ( 3 ), the contrast in protein intake is greater (2) and because the research populations in randomized trials are more sensitive to BP lowering effects since these usually have elevated BP while most observational studies were conducted in the general population $(2,3)$. Strength of our trial is that we used protein isolates to increase protein consumption, which decreases chances of biased findings due to effects of other nutrients. A complicating factor in randomized trials is that dietary compliance may decrease in the longer term. Reviewing the new evidence emerging in 2011 and 2012 in chapter 2, we found that longer-term trials showed less clear effects of dietary proteins on BP than short-term trials. On the other hand, a meta-analyses of 17 randomized trials published between 1984 and 2012 found no effect of study duration on BP responses (2). The DIOGENES trial tested the effects of protein intake and glycemic index on weight maintenance after weight loss in 773 adults in eight European countries (4). Two of the eight European centers provided free food to participants and their family in laboratory supermarkets. In these centers, in which compliance with the high protein (HP) diet was highest, children of participants on the HP diets had significantly lower DBP and mean arterial pressure (MAP) after 6 months compared to the low-protein diets (5). Adult 
DIOGENES trial participants who successfully lost weight and had elevated BP levels maintained a lower SBP and DBP during 6 months weight maintenance in the HP groups than those in the low protein groups. This effect was attenuated after correction for initial BP and weight change (4). Our study adds evidence to this BP-lowering effect of dietary proteins. Current knowledge seems convincing that replacement of dietary carbohydrates for dietary protein lowers BP in individuals with elevated BP.

A question that remains unanswered in our study is whether it is the increased protein content of the diet or the decreased carbohydrate content of the diet that is beneficial for BP. A pooled estimate from three trials comparing the effects of proteins with those of dietary fats (mainly mono-unsaturated fats) on BP revealed no effects when dietary fats were replaced by protein (2). This suggests that increased protein intake is only beneficial for BP when taken at the expense of carbohydrates. However, studies investigating the effects of exchanging carbohydrates and (unsaturated) fats on BP are limited and inconclusive (6). Therefore, it is still not clear whether a reduction of carbohydrate intake or an increase of protein intake is beneficial for BP. Large randomized controlled trials comparing effects of proteins, carbohydrates and fats are necessary to answer this question.

Our study showed beneficial effects of increased dietary protein intake versus maltodextrin intake on BP over a period of 4 weeks (chapter 3). An important question remaining is whether these beneficial effects will still be present in the longer term. Shortterm hypotensive effects of increased protein intake could be weakened in the longerterm, because of longer-term effects like for instance reduced kidney function could oppose the blood pressure lowering effect of dietary proteins (7). Another possible cause of weakened effects after longer-term consumptions is decreased dietary compliance. Longer-term consumption of a certain diet that deviates from the habitual dietary pattern usually goes together with a gradual decrease in dietary compliance (chapter 2). However, a meta-analysis of 17 randomized trials with a mean duration of 17 weeks (range: 3-104 weeks) found no significant association between BP changes and study duration (2). Perhaps it is not the long duration of a diet but the degree of deviance from the habitual diet that reduces dietary compliance. A study encouraging 4 servings of low-fat dairy per day for individuals with a habitual low dairy intake for 12 months found that even though the food was free of charge, participants experienced difficulties with dietary compliance because they perceived 4 servings per day as too much and they had trouble with incorporating the extra dairy intake into their usual diets without gaining weight. In addition, the lack of choice of protein-rich foods was also mentioned as a problem (8). In the DIOGENES study, dietary compliance to the HP diets ( $25 \%$ of energy intake) was also 
decreased towards the end of the 6-month trial. According to the authors, this could have been due to insufficient knowledge of the protein content of local foods (9). In our study, participants exchanged a carbohydrate-rich drink for protein or maltodextrin powder dissolved in water, three times per day. This may be easier to maintain in the long-term because a supplement-based dietary change is not as rigorous as a food-based dietary change. However, our participants were not asked whether they saw challenges in maintaining our study regime in the longer term. Tastiness and monotony, for example, could influence long-term compliance. To maximize dietary compliance, long-term studies should include regular checks to deal with compliance problems in time.

\section{BLOOD PRESSURE LOWERING MECHANISMS OF DIETARY PROTEINS: 4-WEEK STUDY}

We found lower office and ambulatory BP after 4 weeks of protein supplementation. The office BP-measurements were taken at any time of day during visits to the dietitian. In contrast, BP and other hemodynamic variables i.e. heart rate (HR), stroke volume (SV), cardiac output (CO), total peripheral resistance (TPR) and forearm blood flow (FBF) measured in the morning after an overnight fast did not differ significantly between groups after 4 weeks of intervention (data not published). Fasting levels of catecholamines, glucose, insulin, sodium (data not published), renin, aldosterone, angiotensin converting enzyme (ACE), blood pH, bicarbonate (chapter 7) and hematocrit (data not published) also did not differ between groups. However, we did find that endothelial function might be improved after 4 weeks of increased protein intake because fasting values of soluble intercellular adhesion molecule 1 (sICAM) and endothelial dysfunction (ED) Z-scores (composed of sICAM, soluble vascular adhesion molecule 1 (sVCAM), soluble E-selectin (sE-selectin) and von Willebrand factor (vWf)) were significantly lower after the HP diet compared to the maltodextrin diet (chapter 6). Markers of low-grade inflammation (LGI) (LGI Z-scores, composed of C-reactive protein (CRP), SAA and sICAM) did not differ between groups after the intervention (chapter 6). As discussed in chapter $\mathbf{6}$, our finding of improved endothelial function after 4 weeks on a HP diet is new. As far as we know only two other studies compared sICAM levels after increased protein intake to carbohydrate intake (10) or placebo (11). Neither study found an improvement in SICAM after protein supplementation $(10,11)$. Therefore, additional research is necessary to expand evidence on the effects of protein intake on ED markers. Measurement of biomarkers is a good way to unravel mechanisms of ED in a clinical research setting (12). Pulse wave velocity (PWV) and augmentation index (Alx) are also considered to be measures of ED (13). We did find significantly lower fasting PWV after 4 weeks of protein intake compared to maltodextrin $(P=0.02$, data not published). Studies on milk protein also suggest that milk-derived bioactive peptides may reduce PWV (14, 
15). However, caution is warranted with the interpretation of changes in arterial stiffness because arterial stiffness is pressure-dependent. A decrease in stiffness in combination with a decrease in BP does not necessarily mean that arterial wall properties have improved (16). A combination of measurement of 24-hour, daytime and nighttime PWV and Alx, as in a recently published study (17), could be interesting for future studies to see whether changes in ED markers are related to changes in arterial stiffness in the longer term. Arterial stiffness parameters are of great interest because these are strong predictors of cardiovascular diseases (CVD). However, a relationship between improvement of arterial stiffness and decreased risk for cardiovascular events still needs to be determined (18).

Our study revealed no evidence that kidney function was affected by moderately increased protein intake, since fasting values of effective renal plasma flow (ERPF), glomerular filtration rate (GFR), filtration fraction (FF), renal blood flow (RBF), and renal vascular resistance (RVR) did not differ between groups after the 4-week intervention (chapter 7). However, we did find a significantly lower serum creatinine in the protein group after 4 weeks of supplementation ( $P \leq 0.001$, data not published). We cannot explain this difference because fasting GFR (chapter 7) and creatinine clearance (not published) did not differ between groups after 4 weeks of supplementation. Changes in muscle mass (19) are unlikely to explain the difference in serum creatinine in our study. Higher urea and sulfate excretion in the protein group after 4 weeks of supplementation confirmed the higher protein intake in the protein group (chapter 3 ). We also found a higher acid load, measured as urinary potential renal acid load (UPRAL), in the protein group after 4 weeks of supplementation (chapter 7 ). Because dietary protein increases acid load (20), this was in line with our expectations. Despite the higher acid load, which is proposed to adversely affect kidney function (21), we found no adverse effects on kidney hemodynamics (chapter 7) or on albumin excretion (chapter $\mathbf{3}$ ).

We unexpectedly found significantly higher $24 \mathrm{~h}$ urine sodium excretion in the maltodextrin group compared to the protein group after the 4-week intervention (chapter 3), for which we do not have a mechanistic explanation. Therefore, it is most likely that the higher sodium excretion is a result of higher sodium intake in the maltodextrin group, despite comparable sodium content of the protein and maltodextrin supplements and the weekly standard dietary advice in both groups. Sodium intake is positively associated with BP (22). Although changes in sodium excretion were not significantly associated with BP changes in our groups, we cannot fully exclude an effect of salt intake on our findings (chapter 3). During the test days, sodium excretion was similar in both groups (data not published). A difference in sodium intake seems the most plausible explanation for the greater sodium excretion in the maltodextrin group because literature does not support 
higher sodium excretion after a high carbohydrate diet compared to a high protein diet $(23,24)$. Calcium excretion tended to be higher in the protein group after 4 weeks of intervention (chapter $\mathbf{3}$ ) and was significantly higher during both test days (data not published). Intake of calcium is associated with lower BP (25), whereas serum levels of calcium are associated with increased pulse pressure (PP). Mechanisms for the relation between calcium and PP are unclear, but it has been suggested that higher serum calcium levels accelerate vascular calcification. Calcium can also modulate vascular resistance via Ca-transport proteins and it may be involved with renal vascular dysfunction (26).

\section{BLOOD PRESSURE-LOWERING MECHANISMS OF DIETARY PROTEINS: POSTPRANDIAL}

\section{STUDIES}

In our studies, a greater postprandial decrease of BP was found after maltodextrin consumption compared to the protein mix, whether consumed with or without a standardized meal (chapters $\mathbf{4}$ and $\mathbf{5}$ ). This is in agreement with one other study, which found a decrease of MAP within 60 min after ingestion of carbohydrate meals, but not after protein meals in elderly individuals, while neither of these macronutrients induced significant postprandial changes in young individuals (27). The difference between the old and young group in this study could indicate that older individuals have worse postprandial control of BP compared to younger individuals. This could have played a role also in our overweight, middle-aged research group (mean age $\approx 55$ years) with elevated BP. The majority of studies found no significant differences between postprandial BP responses after ingestion of protein and carbohydrate meals (28-32).

To explain differences in postprandial BP levels, several mechanisms involved in the regulation of $\mathrm{CO}$ and TPR were compared between the protein mix and maltodextrin (chapters 4, 5 and 7). No differences in postprandial CO responses were found between maltodextrin and protein meals (chapters 4 and 5). If differences in $\mathrm{CO}$ cannot explain differences in BP, differences in postprandial TPR are the likely cause of different BP responses. In agreement with this, a borderline-significantly greater decrease in TPR was found after maltodextrin supplemented meals compared to meals supplemented with the protein mix (chapter 4). However, no differences in TPR were found after ingestion of maltodextrin or the protein mix without a supplemental meal (chapter 5). An explanation for this discrepancy could be the lower caloric intake in the latter study, which induced a smaller response in TPR and therefore may have hampered the detection of differences between postprandial responses. Another reason could be that TPR cannot be measured directly but is derived from BP and $\mathrm{CO}$ measurements. Thus, imprecisions in measurements of BP and CO could have masked differences in TPR. 
Differences in postprandial TPR responses after ingestion of protein or maltodextrin could be caused by differences in postprandial SNS activation. We found no differences in postprandial SNS activity, measured as plasma and urine levels of epinephrine (E) and norepinephrine (NE), were found between meals (chapter 4). However, plasma E and NE levels may not be sensitive enough to detect small regional differences in SNS activity (33). Thus we cannot fully exclude that the lower TPR after the maltodextrin-supplemented meals (chapter 4) might be due to a lower postprandial SNS activity after the maltodextrin-supplemented meals compared with the protein-supplemented meals. In the second postprandial study (chapter 5) we found a lower postprandial HR after the ingestion of maltodextrin compared with after ingestion of the protein mix, which may also indicate a lower SNS activity after the ingestion of maltodextrin compared with after the ingestion of the protein mix. Therefore, more research with more precise methods to assess (regional) sympathetic activity is necessary to definitively conclude whether dietary proteins differentially affect SNS activity compared to carbohydrates.

Differences in postprandial TPR responses after ingestion of protein or maltodextrin could also be caused by differing postprandial humoral responses. A lower TPR may be related to higher postprandial insulin levels after maltodextrin-supplemented meals (chapter 4 and 5), because insulin is involved in NO-dependent postprandial vasodilation (34), which increases blood flow to the muscles (35). However, nitrite, nitroso compounds (RXNO) and S-nitrosothiols (NOx)-levels, which was proposed to be a mechanism through which insulin induces vasodilation, were higher after the protein mix meal (chapter 5). NOx could have been higher after protein-supplemented meals because of the arginine content (36) of the protein mix and higher postprandial glucagon-like peptide-1 (GLP-1) and glucagon responses, which also induce vasodilation $(37,38)$ (chapter 5 ). Despite higher NOx, GLP-1 and glucagon after the protein mix (chapter 5), BP decreased more after maltodextrin compared to the protein mix.

Another mechanism that could have reduced postprandial TPR after ingestion of maltodextrin compared with ingestion of the protein mix is decreased ED (39). However, we found no clear differences in postprandial levels of markers of ED and LGI between the protein mix and maltodextrin (chapter 6). To our knowledge, only one other study compared postprandial changes in markers of ED and LGI after protein and carbohydrate intake (32). Postprandial responses in interleukin 6 (IL-6), CRP and tumor necrosis factor $\alpha$ (TNF $\alpha$ ) did not differ between meals supplemented with whey protein, casein protein or glucose in that study (32). However, a large number of measurable biomarkers of endothelial function, inflammation and cardiovascular risk are available nowadays (40) and we investigated only a fraction of these markers. In addition to the unclear findings on markers of ED, 4-hour postprandial responses of arterial stiffness, measured as PWV and Alx, did not differ between the protein mix and maltodextrin (chapter 5). Twelve-hour 
postprandial PWV responses to protein and carbohydrate supplemented meals also did not differ between groups (data not published).

Finally, we proposed that modulation of the RAAS could influence (postprandial) BP via changes in TPR and CO. Peptide-induced ACE inhibition has been proposed to cause vasodilation by decreased formation of angiotensin II, which is a strong vasoconstrictor. Even though several studies have shown that milk-derived peptides can reduce $\operatorname{BP}(14,41$ 44), ACE inhibition has not been confirmed in human trials (41-43). In agreement with these findings, we also found no evidence of long-term or postprandial ACE inhibition by the protein mix compared to maltodextrin (chapters 5 and 7). For this reason, systemic ACE inhibition seems unlikely to be the mechanism explaining BP lowering effects of dietary proteins. However, we cannot exclude a local ACE inhibitory effect at the tissue levels by dietary proteins. Changes in extracellular volume (ECV) could also affect BP. Although we found significantly greater postprandial renin after the maltodextrinsupplemented meals on the first day of the intervention (chapter 7), we found no differences in fasting and postprandial levels of aldosterone between the protein and maltodextrin group (chapter 7). Therefore, alteration of ECV via the RAAS seems unlikely to explain decreased BP after 4 weeks on a HP diet.

In summary, postprandial BP decreased more after maltodextrin consumption, than after protein consumption, which is most likely to be the result of decreased TPR induced by insulin release. However, insufficient SNS activity after maltodextrin consumption could also have played a role.

\section{LONG TERM EFFECTS VERSUS ACUTE EFFECTS OF DIETARY PROTEIN ON BLOOD}

\section{PRESSURE}

We demonstrated that 4-week effects on office BP and the postprandial BP effects of protein and maltodextrin were not similar with different mechanisms being involved in the regulation of long-term and postprandial BP. This is not surprising because BP is regulated by different mechanisms acting in the short term and long-term. For instance, the baroreflex is a short-term BP regulation mechanism, whereas aldosterone regulates BP more long-term via control of ECV. Our finding that endothelial function and PWV are improved after 4 weeks consumption of the protein mix, may indicate that dietary protein introduces long-term structural changes of the vascular endothelium, but this needs to be confirmed in future studies. Even though postprandial BP responses could not predict long-term responses, acute studies are of importance because humans are in the postprandial state for the greater part of the day. Our findings stress that acute studies are an efficient way to explore effects of (macro)nutrients on BP regulation, but long-term 
effects on BP cannot be predicted from these studies. Therefore, BP-lowering (macro)nutrients studied postprandially also need to be compared in long-term studies.

\section{COMPARISONS BETWEEN CARBOHYDRATE SOURCES}

The different effects on BP of protein and maltodextrin intake, both acutely and in the long term (chapter 3 and 4), gave rise to the question whether the carbohydrate source chosen in our study could have affected our study outcomes. To investigate this question, we compared postprandial responses after intake of $0.6 \mathrm{~g} / \mathrm{kg}$ maltodextrin, which is a glucose polymer, to those after intake of $0.6 \mathrm{~g} / \mathrm{kg}$ sucrose (chapters $\mathbf{5}$ and $\mathbf{6}$ ). Sucrose was chosen because it is a commonly consumed disaccharide containing $50 \%$ glucose and $50 \%$ fructose. Effects of chronic fructose intake on BP have been studied rather extensively, because chronic intake of fructose results in diet-induced hypertension in rats (45). However, the situation is different in humans. Three recent meta-analyses found no adverse effects of fructose intake on BP in humans. One meta-analysis even reported that fructose reduces DBP and MAP compared to other carbohydrates (46). Compared to glucose, fructose was found to reduce SBP and MAP in another meta-analysis (47). Another review found that fructose increases SBP, but this effect became insignificant after correction for heterogeneity between studies (48).

We found a significantly greater postprandial decrease in BP at $1 \mathrm{~h}$ after ingestion of maltodextrin compared to sucrose (chapter 5). Higher postprandial BP levels after ingestion of fructose compared to glucose have been reported before (49-51), while no differences in postprandial BP were found after the ingestion of glucose compared to sucrose $(50,51)$ or a glucose-fructose drink $(52)$. Maltodextrin also induced a greater fall in BP compared to sucrose with significantly higher postprandial glucose, GLP-1 and insulin levels (chapter 5). Fructose has been reported to induce a smaller rise in glucose, insulin and GLP-1 levels compared to glucose (53). Because of their vasoactive characteristics the higher insulin and GLP-1 levels may explain the lower BP after maltodextrin $(37,54)$. A BP-lowering effect of insulin and GLP-1 had to be induced via a nitric oxide (NO)-independent vasodilatory pathway, since NO did not differ until $2 \mathrm{~h}$ after ingestion of carbohydrates.

In summary, because postprandial BP responses differed after sucrose and maltodextrin ingestion, we suspect that long-term effects of sucrose and maltodextrin intake may also be different. In contrast to rat studies suggesting that fructose induces hypertension, human studies found a favorable or no effect on BP of fructose intake compared to other carbohydrates. If fructose lowers BP compared to glucose, as suggested by recent metaanalyses $(46,47)$, sucrose consumption may induce a decrease in BP when compared to maltodextrin consumption. As a consequence, the BP lowering effect of the protein mix 
could be smaller, non-existent or even unfavourable compared to sucrose. Further investigation is necessary to find out which type of carbohydrate should be exchanged with dietary protein to induce an optimal effect on BP.

\section{COMPARISON OF PROTEIN SOURCES}

Several studies have already added information to the question whether long-term consumption of a certain type of protein would be more beneficial for BP than other protein types. In chapter $\mathbf{2}$, we argued that observational studies suggest that plant protein may be more beneficial for lowering BP than animal proteins. This is in agreement with a current meta-analysis, which showed a week yet significant inverse relationship between plant protein intake and systolic BP in cross-sectional studies (2). This association was found after exclusion of a cross-sectional study conducted in Japan (55), which found a direct association between plant protein intake and BP and an inverse association between animal protein intake and BP. The reason that the findings in this study are in contrast with other cross-sectional studies may be due to the fact that Japanese eat more animal protein derived from fish compared to Chinese and Western countries, and fish protein may be more beneficial compared to meat protein (2). On the other hand, randomized trials do not indicate different effects of plant protein and animal protein intake on BP (chapter 2 ). A recently published randomized crossover trial compared the effects of 8 weeks of lupin protein isolate ( $25 \mathrm{~g} /$ day) to milk protein isolate and found no differences in BP between the two protein sources (56). Meta-analyses of randomized trials also found no differences in BP lowering effects of animal and plant protein sources $(1,2,57)$. However, most trials compared soy protein to milk protein or diets composed of several animal protein sources versus several plant protein sources (1). A recently published crossover trial compared BP lowering effects of 5 weeks of a healthy American diet (17 energy\% protein), dietary approaches to stop hypertension (DASH) diet (18 energy\% protein, 9\% lean beef), BOLD diet (DASH diet with lean beef as main protein source; $19 \%$ protein of which $53 \%$ from lean beef) and a BOLD+ diet (BOLD diet with a higher energy\% derived from proteins, $27 \%$ protein, lean beef $42 \%$ ) in normotensive individuals. The BOLD+ diet significantly reduced SBP compared to the other three diets, which suggests that meat proteins are also capable of lowering BP (58). To further investigate the question whether a particular protein source may be more beneficial than other sources, other promising protein sources need to be evaluated.

To address this question, we compared postprandial changes in BP and related mechanisms between three protein sources (pea protein, milk protein and egg-white protein) in chapters 5 and 6. 
Postprandial BP was significantly higher after egg-white protein compared to the other two protein sources (chapter 5). Only one other study compared postprandial BP responses after different protein sources and found no differences between whey and casein protein in 6-hour BP responses (32). HR was significantly lower after egg-white protein compared to pea protein, which may indicate that pea protein induced increased SNS activation in order to maintain BP. The amino acid tryptophan has been suggested to suppress SNS activation (59). Tryptophan was lowest in pea protein $(1 \mathrm{~g} / 100 \mathrm{~g})$ and highest in egg-white protein $(1.2 \mathrm{~g} / 100 \mathrm{~g}$, chapter 5$)$, thus tryptophan content might explain lower SNS activation after egg-white protein compared to pea protein.

Even though we could not demonstrate a difference in TPR between protein sources, we did find differences between protein sources in mechanisms related to TPR. Egg white protein induced the smallest increases in insulin and glucagon and the smallest fall in Alx, while pea protein induced the greatest NOx and glucagon responses compared to the other two proteins (chapter 5 ). Other studies have already shown that different proteins and amino acids have different insulin- (60-62) and glucagon-stimulating $(60,62,63)$ properties. The amino acid arginine, which was present in the highest amount in pea protein, is involved in the production of NO (64). Despite higher hormonal values, NOx levels after ingestion of milk protein did not differ significantly from egg-white protein and cannot explain why BP remained lower after milk protein consumption compared to eggwhite protein consumption. Ingestion of milk protein may reduce BP levels via different mechanism than ingestion of pea protein, for instance via ACE inhibition $(65,66)$. However, we did not find differences in ACE activity between protein sources. Perhaps higher insulin and glucagon levels after milk protein may have decreased BP via NO independent vasodilation. For instance, insulin also stimulates endothelium-derived hyperpolarizing factor (EDHF) and prostaglandin $\mathrm{PGI}_{2}$. Both factors induce vasodilation (54). Another mechanism that could have been affected by the different protein sources is arterial function. However, ED and LGI Z-scores (chapter 6) and PWV (chapter 5) did not differ between protein sources. In contrast, postprandial Alx did differ between protein sources (chapter 6). We suggested that this difference could be the result of different postprandial insulin responses (67). However, Alx can also be influenced by other factors, like PWV, BP, and arterial tone, which makes interpretation of the findings difficult (68). Therefore, we cannot conclude that arterial stiffness itself was affected postprandially by the different protein sources.

In summary, protein sources induced different postprandial BP responses, and therefore, long-term BP responses may also be affected differently by different protein sources. Eggwhite protein and pea protein introduced the greatest contrast in postprandial responses and are therefore an interesting pair to compare in a long-term study. On the other hand, 
milk protein is also interesting because milk-derived bioactive peptides have been shown to improve PWV in the long-term (14).

\section{CONCLUSION AND FUTURE RESEARCH PERSPECTIVES}

The studies described in this thesis added to the large pile of evidence that dietary protein intake lowers BP (chapter $\mathbf{3}$ ) without adversely affecting kidney function, at least in the short-term (chapters 3 and 7). In addition, several mechanisms via which dietary proteins could lower BP were explored. Some evidence was found that improved endothelial function plays a role in BP lowering by dietary protein intake. ED Z-scores, sICAM (chapter 6) and PWV (not published) were decreased after 4 weeks on the HP diet compared to the maltodextrin diet. In addition postprandial NO was increased after the protein mix compared to maltodextrin (chapter 5). No evidence was found that decreased sympathetic activation plays a role (chapter 4). However, more research is necessary to confirm this finding. Changes in RAAS activity also did not serve as a plausible explanation in our studies. The question, which protein source in the mix was most beneficial for BP could not be answered in our studies. However, protein sources may differ in their effects on postprandial BP (chapter 5), which could indicate that effects of long-term consumption on BP may also differ between protein sources.

The questions that are still remaining:

1. Do the BP lowering effects of dietary proteins after 4 weeks still exist after longerterm consumption?

2. Which protein source is most beneficial for BP lowering after long-term consumption?

3. Can future studies confirm our findings on changes in endothelial function and inflammation?

4. If dietary proteins lower BP in the long term, should the effect be established by intake of protein supplements or protein rich foods?

5. Does increased protein intake or decreased carbohydrate intake explain the beneficial effects of consuming proteins at the expense of carbohydrates on BP?

6. Does a HP diet have adverse health effects in the longer-term? 


\section{REFERENCES}

1. Rebholz CM, Friedman EE, Powers LJ, Arroyave WD, He J, Kelly TN. Dietary protein intake and blood pressure: a meta-analysis of randomized controlled trials. Am J Epidemiol. 2012;176 Suppl 7:S27-43.

2. Tielemans SM, Altorf-van der Kuil W, Engberink MF, Brink EJ, van Baak MA, Bakker SJ, et al. Intake of total protein, plant protein and animal protein in relation to blood pressure: a meta-analysis of observational and intervention studies. J Hum Hypertens. 2013;27(9):564-71.

3. Altorf-van der Kuil W, Engberink MF, Brink EJ, van Baak MA, Bakker SJ, Navis G, et al. Dietary protein and blood pressure: a systematic review. PLoS One. 2010;5(8):e12102.

4. Engberink MF, Geleijnse JM, Bakker SJ, Larsen TM, Handjieva-Darlesnka T, Kafatos A, et al. Effect of a high-protein diet on maintenance of blood pressure levels achieved after initial weight loss: the DiOGenes randomized study. J Hum Hypertens. 2014.

5. Damsgaard CT, Papadaki A, Jensen SM, Ritz C, Dalskov SM, Hlavaty P, et al. Higher protein diets consumed ad libitum improve cardiovascular risk markers in children of overweight parents from eight European countries. J Nutr. 2013;143(6):810-7.

6. Schwab U, Lauritzen L, Tholstrup T, Haldorssoni T, Riserus U, Uusitupa M, et al. Effect of the amount and type of dietary fat on cardiometabolic risk factors and risk of developing type 2 diabetes, cardiovascular diseases, and cancer: a systematic review. Food Nutr Res. 2014;58.

7. Viazzi F, Pontremoli R. Blood pressure, albuminuria and renal dysfunction: the 'chicken or egg' dilemma. Nephrol Dial Transplant. 2014.

8. Crichton GE, Howe PR, Buckley JD, Coates AM, Murphy KJ, Bryan J. Long-term dietary intervention trials: critical issues and challenges. Trials. 2012;13(1):111.

9. Larsen TM, Dalskov SM, van Baak M, Jebb SA, Papadaki A, Pfeiffer AF, et al. Diets with high or low protein content and glycemic index for weight-loss maintenance. N Engl J Med. 2010;363(22):2102-13.

10. Rebholz CM, Reynolds K, Wofford MR, Chen J, Kelly TN, Mei H, et al. Effect of soybean protein on novel cardiovascular disease risk factors: a randomized controlled trial. Eur J Clin Nutr. 2013;67(1):58-63.

11. Ballard KD, Bruno RS, Seip RL, Quann EE, Volk BM, Freidenreich DJ, et al. Acute ingestion of a novel whey-derived peptide improves vascular endothelial responses in healthy individuals: a randomized, placebo controlled trial. Nutr J. 2009;8:34.

12. Inoue T, Matsuoka H, Higashi Y, Ueda S, Sata M, Shimada KE, et al. Flow-mediated vasodilation as a diagnostic modality for vascular failure. Hypertens Res. 2008;31(12):2105-13.

13. Le Brocq M, Leslie SJ, Milliken P, Megson IL. Endothelial dysfunction: from molecular mechanisms to measurement, clinical implications, and therapeutic opportunities. Antioxid Redox Signal. 2008;10(9):1631-74

14. Nakamura T, Mizutani J, Ohki K, Yamada K, Yamamoto N, Takeshi M, et al. Casein hydrolysate containing Val-Pro-Pro and lle-Pro-Pro improves central blood pressure and arterial stiffness in hypertensive subjects: a randomized, double-blind, placebo-controlled trial. Atherosclerosis. 2011;219(1):298-303.

15. Crichton GE, Elias MF, Dore GA, Abhayaratna WP, Robbins MA. Relations between dairy food intake and arterial stiffness: pulse wave velocity and pulse pressure. Hypertension. 2012;59(5):1044-51.

16. London GM, Pannier B. Arterial functions: how to interpret the complex physiology. Nephrol Dial Transplant. 2010;25(12):3815-23.

17. Kuznetsova TY, Korneva VA, Bryantseva EN, Barkan VS, Orlov AV, Posokhov IN, et al. The 24-hour pulse wave velocity, aortic augmentation index, and central blood pressure in normotensive volunteers. Vascular health and risk management. 2014;10:247-51.

18. Laurent S, Boutouyrie P. Recent advances in arterial stiffness and wave reflection in human hypertension. Hypertension. 2007;49(6):1202-6. 
19. Patel SS, Molnar MZ, Tayek JA, Ix JH, Noori N, Benner D, et al. Serum creatinine as a marker of muscle mass in chronic kidney disease: results of a cross-sectional study and review of literature. Journal of cachexia, sarcopenia and muscle. 2013;4(1):19-29.

20. Remer T, Manz F. Estimation of the renal net acid excretion by adults consuming diets containing variable amounts of protein. Am J Clin Nutr. 1994;59(6):1356-61.

21. van den Berg E, Hospers FA, Navis G, Engberink MF, Brink EJ, Geleijnse JM, et al. Dietary acid load and rapid progression to end-stage renal disease of diabetic nephropathy in Westernized South Asian people. J Nephrol. 2011;24(1):11-7.

22. Sarkkinen ES, Kastarinen MJ, Niskanen TH, Karjalainen PH, Venalainen TM, Udani JK, et al. Feasibility and antihypertensive effect of replacing regular salt with mineral salt -rich in magnesium and potassium- in subjects with mildly elevated blood pressure. Nutr J. 2011;10:88.

23. Defronzo RA, Cooke CR, Andres R, Faloona GR, Davis PJ. The effect of insulin on renal handling of sodium, potassium, calcium, and phosphate in man. J Clin Invest. 1975;55(4):845-55.

24. Lauridsen TG, Vase H, Starklint J, Bech JN, Pedersen EB. Protein-enriched diet increases water absorption via the aquaporin-2 water channels in healthy humans. Nephrol Dial Transplant. 2010;25(8):2502-10.

25. Chrysant SG, Chrysant GS. An update on the cardiovascular pleiotropic effects of milk and milk products. J Clin Hypertens (Greenwich). 2013;15(7):503-10.

26. Mateus-Hamdan L, Beauchet O, Rolland Y, Schott AM, Annweiler C. Association of calcium concentration with pulse pressure in older women: data from a large population-based multicentric study. The journal of nutrition, health \& aging. 2014;18(3):323-9.

27. Ferreira-Filho SR, de Castro Rodrigues Ferreira AC, de Oliveira PC. Systemic hemodynamic changes in young and elderly normotensive individuals after ingestion of meals with high lipid, protein, and carbohydrate contents. Blood Press Monit. 2012;17(3):110-5.

28. Ferreira-Filho SR, Ferreira AC, Oliveira PC, Moreira JF, Ribeiro EC, Oliveira AM, et al. Systemic hemodynamic changes in elderly hypertensive patients after ingesting foods with lipid, protein, and carbohydrate contents. Journal of clinical hypertension. 2009;11(5):271-6.

29. Hoost U, Kelbaek H, Rasmusen H, Court-Payen M, Christensen NJ, Pedersen-Bjergaard U, et al. Haemodynamic effects of eating: the role of meal composition. Clin Sci (Lond). 1996;90(4):269-76.

30. Waaler BA, Eriksen M. Post-prandial cardiovascular responses in man after ingestion of carbohydrate, protein or fat. Acta Physiol Scand. 1992;146(3):321-7.

31. Potter JF, Heseltine D, Hartley G, Matthews J, MacDonald IA, James OF. Effects of meal composition on the postprandial blood pressure, catecholamine and insulin changes in elderly subjects. Clin Sci (Lond). 1989;77(3):265-72.

32. Pal S, Ellis V. Acute effects of whey protein isolate on blood pressure, vascular function and inflammatory markers in overweight postmenopausal women. Br J Nutr. 2011;105(10):1512-9.

33. Grassi G, Esler M. How to assess sympathetic activity in humans. J Hypertens. 1999;17(6):719-34.

34. Scherrer $U$, Sartori C. Insulin as a vascular and sympathoexcitatory hormone: implications for blood pressure regulation, insulin sensitivity, and cardiovascular morbidity. Circulation. 1997;96(11):4104-13.

35. van Baak MA. Meal-induced activation of the sympathetic nervous system and its cardiovascular and thermogenic effects in man. Physiol Behav. 2008;94(2):178-86.

36. Bode-Boger SM, Boger RH, Galland A, Tsikas D, Frolich JC. L-arginine-induced vasodilation in healthy humans: pharmacokinetic-pharmacodynamic relationship. Br J Clin Pharmacol. 1998;46(5):489-97.

37. Wang B, Ni Y, Zhong J, Sun F. Effects of incretins on blood pressure: a promising therapy for type 2 diabetes mellitus with hypertension. J Diabetes. 2012;4(1):22-9.

38. Farah AE. Glucagon and the circulation. Pharmacol Rev. 1983;35(3):181-217.

39. Vanhoutte PM, Shimokawa H, Tang EH, Feletou M. Endothelial dysfunction and vascular disease. Acta Physiol (Oxf). 2009;196(2):193-222. 
40. Anderson L. Candidate-based proteomics in the search for biomarkers of cardiovascular disease. $J$ Physiol. 2005;563(Pt 1):23-60.

41. Boelsma E, Kloek J. IPP-rich milk protein hydrolysate lowers blood pressure in subjects with stage 1 hypertension, a randomized controlled trial. Nutr J. 2010;9:52.

42. Turpeinen AM, Ehlers PI, Kivimaki AS, Jarvenpaa S, Filler I, Wiegert E, et al. Ile-Pro-Pro and Val-Pro-Pro tripeptide-containing milk product has acute blood pressure lowering effects in mildly hypertensive subjects. Clin Exp Hypertens. 2011;33(6):388-96.

43. de Leeuw PW, van der Zander K, Kroon AA, Rennenberg RM, Koning MM. Dose-dependent lowering of blood pressure by dairy peptides in mildly hypertensive subjects. Blood Press. 2009;18(1-2):44-50.

44. Seppo L, Jauhiainen T, Poussa T, Korpela R. A fermented milk high in bioactive peptides has a blood pressure-lowering effect in hypertensive subjects. Am J Clin Nutr. 2003;77(2):326-30.

45. Vasdev S, Singal P, Gill V. The antihypertensive effect of cysteine. Int J Angiol. 2009;18(1):7-21.

46. Ha V, Sievenpiper JL, de Souza RJ, Chiavaroli L, Wang DD, Cozma Al, et al. Effect of fructose on blood pressure: a systematic review and meta-analysis of controlled feeding trials. Hypertension. 2012;59(4):787-95.

47. Sievenpiper JL, de Souza RJ, Cozma Al, Chiavaroli L, Ha V, Mirrahimi A. Fructose vs. glucose and metabolism: do the metabolic differences matter? Curr Opin Lipidol. 2014;25(1):8-19.

48. Kelishadi R, Mansourian M, Heidari-Beni M. Association of fructose consumption and components of metabolic syndrome in human studies: a systematic review and meta-analysis. Nutrition (Burbank, Los Angeles County, Calif). 2014;30(5):503-10.

49. Brown CM, Dulloo AG, Yepuri G, Montani JP. Fructose ingestion acutely elevates blood pressure in healthy young humans. Am J Physiol Regul Integr Comp Physiol. 2008;294(3):R730-7.

50. Grasser EK, Dulloo A, Montani JP. Cardiovascular responses to the ingestion of sugary drinks using a randomised cross-over study design: does glucose attenuate the blood pressure-elevating effect of fructose? Br J Nutr. 2014;112(2):183-92.

51. Visvanathan R, Chen R, Garcia M, Horowitz M, Chapman I. The effects of drinks made from simple sugars on blood pressure in healthy older people. Br J Nutr. 2005;93(5):575-9.

52. Bidwell AJ, Holmstrup ME, Doyle RP, Fairchild TJ. Assessment of endothelial function and blood metabolite status following acute ingestion of a fructose-containing beverage. Acta Physiol (Oxf). 2010;200(1):35-43.

53. Kuhre RE, Gribble FM, Hartmann B, Reimann F, Windelov JA, Rehfeld JF, et al. Fructose stimulates GLP-1 but not GIP secretion in mice, rats, and humans. Am J Physiol Gastrointest Liver Physiol. 2014;306(7):G622-30.

54. Muniyappa R, Yavuz S. Metabolic actions of angiotensin II and insulin: a microvascular endothelial balancing act. Molecular and cellular endocrinology. 2013;378(1-2):59-69.

55. Umesawa M, Sato S, Imano H, Kitamura A, Shimamoto T, Yamagishi K, et al. Relations between protein intake and blood pressure in Japanese men and women: the Circulatory Risk in Communities Study (CIRCS). Am J Clin Nutr. 2009;90(2):377-84.

56. Bahr M, Fechner A, Kramer J, Kiehntopf M, Jahreis G. Lupin protein positively affects plasma LDL cholesterol and LDL:HDL cholesterol ratio in hypercholesterolemic adults after four weeks of supplementation: a randomized, controlled crossover study. Nutr J. 2013;12(1):107.

57. Dong JY, Tong X, Wu ZW, Xun PC, He K, Qin LQ. Effect of soya protein on blood pressure: a meta-analysis of randomised controlled trials. Br J Nutr. 2011;106(3):317-26.

58. Roussell MA, Hill AM, Gaugler TL, West SG, Ulbrecht JS, Vanden Heuvel JP, et al. Effects of a DASH-like diet containing lean beef on vascular health. J Hum Hypertens. 2014.

59. Vasdev S, Stuckless J. Antihypertensive effects of dietary protein and its mechanism. Int J Angiol. 2010;19(1):e7-e20. 
60. Morifuji M, Ishizaka M, Baba S, Fukuda K, Matsumoto H, Koga J, et al. Comparison of different sources and degrees of hydrolysis of dietary protein: effect on plasma amino acids, dipeptides, and insulin responses in human subjects. J Agric Food Chem. 2010;58(15):8788-97.

61. van Loon $L$, Saris $W H$, Verhagen $H$, Wagenmakers AJ. Plasma insulin responses after ingestion of different amino acid or protein mixtures with carbohydrate. Am J Clin Nutr. 2000;72(1):96-105.

62. Gannon MC, Nuttall FQ. Amino acid ingestion and glucose metabolism--a review. IUBMB Life. 2010;62(9):660-8.

63. Claessens $M$, Calame $W$, Siemensma $A D$, van Baak MA, Saris WH. The effect of different protein hydrolysate/carbohydrate mixtures on postprandial glucagon and insulin responses in healthy subjects. Eur J Clin Nutr. 2009;63(1):48-56.

64. Luiking YC, Ten Have GA, Wolfe RR, Deutz NE. Arginine de novo and nitric oxide production in disease states. Am J Physiol Endocrinol Metab. 2012;303(10):E1177-89.

65. Cicero AF, Aubin F, Azais-Braesco V, Borghi C. Do the lactotripeptides isoleucine-proline-proline and valine-proline-proline reduce systolic blood pressure in European subjects? A meta-analysis of randomized controlled trials. Am J Hypertens. 2013;26(3):442-9.

66. Qin LQ, Xu JY, Dong JY, Zhao Y, van Bladeren P, Zhang W. Lactotripeptides intake and blood pressure management: a meta-analysis of randomised controlled clinical trials. Nutr Metab Cardiovasc Dis. 2013;23(5):395-402.

67. Westerbacka J, Wilkinson I, Cockcroft J, Utriainen T, Vehkavaara S, Yki-Jarvinen H. Diminished wave reflection in the aorta. A novel physiological action of insulin on large blood vessels. Hypertension. 1999;33(5):1118-22.

68. Hamilton PK, Lockhart CJ, Quinn CE, McVeigh GE. Arterial stiffness: clinical relevance, measurement and treatment. Clin Sci (Lond). 2007;113(4):157-70. 
Summary 
Cardiovascular diseases are responsible for a large part of all deaths worldwide. Hypertension is an important risk factor for cardiovascular diseases and can be modulated by lifestyle changes like a healthy diet and increased physical activity. A heart healthy diet, for instance, includes restricted amounts of salt intake and high intake of fruit and vegetables. Intake of dietary proteins has been suggested to improve blood pressure (BP), but it is still unclear which protein sources have the greatest beneficial effect. The aim of this thesis was to investigate whether consumption of a mix of animal and plant protein sources affects BP after 4 weeks and to explore whether dietary proteins influence blood pressure by affecting sympathetic nervous system activity (SNS), humoral mechanisms, endothelial function, the renin-angiotensin-aldosterone-system (RAAS), and/or kidney function.

Reviewing new evidence emerging in 2011 and 2012 in chapter 2 we found that dietary proteins intake at the expense of carbohydrate intake may be beneficial for BP. Evidence suggested no difference in BP-lowering effects between plant proteins and animal proteins, but different protein sources may lower BP via different mechanisms like increasing nitric oxide (NO) availability, angiotensin converting enzyme (ACE) inhibition or release of hormones like insulin and glucagon-like-peptide-1 (GLP-1).

The dietary proteins and BP (PROPRES) trial aimed to determine whether dietary proteins affect BP. We compared the effects of 4 weeks of increased protein intake with maltodextrin intake in overweight and obese individuals with untreated elevated BP in chapter 3. Participants replaced three consumptions of a sugary drink ( $20 \mathrm{~g}$ sugar per consumption) per day isoenergetically with a protein mix, which consisted of $20 \%$ pea protein, $20 \%$ soy protein, $30 \%$ egg-white protein and $30 \%$ milk protein or with maltodextrin. Participants consuming the protein mix had a larger reduction in BP after 4 weeks compared to participants consuming maltodextrin. A subgroup of PROPRES trial volunteers participated in extra test days on the first day and last day of the intervention. Fasting values of pulse wave velocity (PWV, not published), endothelial dysfunction (ED) Zscores (composed of soluble intercellular adhesion molecule 1 (sICAM), soluble vascular adhesion molecule 1 (sVCAM), soluble E-selectin (sE-selectin) and von Willebrand factor (vWf)) and sICAM were lower in the protein group compared to the maltodextrin group after the 4-week intervention (chapter 6 ). This suggests that ED was improved after 4 weeks on the protein mix diet. Despite a significantly higher acid load from the high protein diet we found no adverse effects of the protein mix compared to maltodextrin on renal hemodynamics in our research population with healthy kidney function (chapter 7 ). To further explore the effects of the protein mix on BP regulation, we studied 12-hour postprandial responses after meals supplemented with the protein mix or maltodextrin during the two extra test days in the PROPRES subgroup (chapters 4, 6 and 7). A significantly greater postprandial decrease in BP was found after the maltodextrin- 
supplemented meals compared to the meals supplemented with the protein mix. Total peripheral resistance (TPR) tended to decrease further in the maltodextrin group, suggesting that vasodilation played a role in the difference in postprandial BP (chapter 4). We found no compelling evidence of a between-group difference in postprandial responses of SNS activity (chapter 4), ED, LGI (chapter 6) RAAS and renal hemodynamics (chapter 7). We suggested that the higher postprandial insulin response after the maltodextrin-supplemented meals could have induced the greater decrease in TPR (chapter 4). In a second study (chapter 5) we compared 4-hour hormonal responses after ingestion of $0.6 \mathrm{~g} / \mathrm{kg}$ of the protein mix to $0.6 \mathrm{~g} / \mathrm{kg}$ maltodextrin in a similar research population as the PROPRES study. We hypothesized that insulin, GLP-1, and glucagon would induce greater NO-dependent vasodilation. Again, maltodextrin induced a greater decrease in BP and a greater increase in postprandial insulin. However, ingestion of the protein mix resulted in the greatest postprandial levels of GLP-1, glucagon and nitrite, nitroso compounds (RXNO) and S-nitrosothiols (NOx). This suggests that the greater decrease in BP after maltodextrin was not mediated via NO-dependent vasodilation.

The chronic effects of 4 weeks of increased protein intake compared to maltodextrin intake were different from the acute effects of protein ingestion compared to maltodextrin ingestion. The protein mix reduced BP in the long-term, while postprandial $\mathrm{BP}$ was reduced more after ingestion of maltodextrin. This finding suggests that postprandial responses to the ingestion of dietary protein cannot directly predict the effects of long-term intake. In addition, different BP regulation mechanisms may be working postprandial and in the long term.

For a further exploration of the effects of dietary proteins on BP regulation we compared 4-hour postprandial responses after ingestion of $0.6 \mathrm{~g} / \mathrm{kg}$ pea protein, milk protein, and egg-white protein (chapters 5 and 6). Egg-white protein induced a significantly greater increase in BP compared to the other two protein sources. In addition, egg-white protein induced the smallest increases in insulin and glucagon and the smallest decrease in augmentation index (Alx) compared to pea protein and milk protein. Ingestion of pea protein resulted in the greatest increases in glucagon and NOx. These findings suggest that pea protein ingestion resulted in lower postprandial BP due to higher insulin and glucagon levels, which could have induced greater vasodilation via NO-dependent pathways. Milk protein resulted in lower BP compared to egg-white protein via an NO-independent pathway, because NOx levels were similar after ingestion of the two protein sources. These studies suggest that dietary proteins originating from different food sources can affect postprandial BP differently. Future studies should focus on the effects of chronic intake of these protein sources, because we cannot predict long-term effects from our postprandial studies. In addition, two other questions that still need to be answered are: "is the effect of increased protein intake on BP a result of increased protein intake or 
decreased carbohydrate intake?" and "does the protein mix improve BP compared to maltodextrin beyond 4 weeks of supplementation, without any adverse effects on kidney function?" 
Samenvatting 
Wereldwijd zijn hart- en vaatziekten een belangrijke doodsoorzaak. Hoge bloeddruk (hypertensie) is een belangrijke risicofactor voor het krijgen van hart- en vaatziekten. Leefstijlveranderingen zoals het volgen van een gezond voedingspatroon en meer lichaamsbeweging hebben een gunstige invloed op de bloeddruk. Een dieet om de gezondheid van het hart te waarborgen bevat bijvoorbeeld een beperkte hoeveelheid zout en een grote hoeveelheid fruit en groenten. Een eiwitrijk voedingspatroon kan de bloeddruk verbeteren, maar het is nog onduidelijk of dat door de eiwitten zelf komt en zo ja, welke eiwitbronnen het beste effect hebben. Het doel van dit proefschrift was om te onderzoeken of het eten van een mengsel van gezuiverde dierlijke en plantaardige eiwitten gedurende 4 weken invloed heeft op de bloeddruk en om uit te zoeken of (verschillende soorten) eiwitten de bloeddruk beïnvloeden via veranderingen in sympathische activiteit, humorale mechanismen, endotheelfunctie, het renineangiontensine-aldosteron-systeem en/of nierfunctie.

In een review van studies gepubliceerd in 2011 en 2012 (hoofdstuk 2) vonden we dat het verhogen van de inname van eiwitten ten koste van de inname van koolhydraten de bloeddruk zou kunnen verlagen. We vonden geen bewijs voor een verschil in bloeddrukverlagende effecten van plantaardige ten opzichte van dierlijke eiwitten. Echter, eiwitten afkomstig van verschillende voedingsmiddelen kunnen de bloeddruk wel via verschillende mechanismen beïnvloeden, zoals het verhogen van de beschikbaarheid stikstofoxide (NO), het inhiberen van activiteit van het angiotensin-converting-enzyme (ACE) of afgifte van hormonen zoals insuline en glucagon-like peptide-1 (GLP-1).

Het effect van voedingseiwitten op bloeddruk werd getest in de "PROteins and blood PRESsure" (PROPRES) studie. In de PROPRES studie werden de effecten op de bloeddruk van 4 weken verhoogde eiwitinname vergeleken met 4 weken maltodextrine-inname in vrijwilligers met overgewicht of obesitas en een verhoogde bloeddruk (hoofdstuk 3 ). De deelnemers gebruikten geen medicijnen om de hoge bloeddruk te behandelen. De ene groep deelnemers verving, gedurende 4 weken, 3 consumpties van een suikerhoudende drank (20 g suiker per consumptie) door een eiwitmengsel, bestaande uit $20 \%$ erwteneiwit, $20 \%$ soja-eiwit, $30 \%$ kippenei-eiwit en $30 \%$ melkeiwit, met dezelfde hoeveelheid calorieën. De andere groep verving de suikerhoudende drank door maltodextrine, ook met dezelfde hoeveelheid calorieën. Deelnemers die het eiwitmengsel consumeerden hadden een grotere daling van de bloeddruk na 4 weken dan deelnemers die maltodextrine namen. Een subgroep van de deelnemers in de PROPRES studie deed mee aan extra testdagen op de eerste en laatste dag van de interventie. Gevaste waarden van pols-golfsnelheid (PWV, niet gepubliceerd), endotheeldysfunctie (ED) Z-scores (bestaande uit soluble intercellular adhesion molecule 1 (sICAM), soluble vascular adhesion molecule 1 (sVCAM), soluble E-selectin (sE-selectin) en von Willebrand factor (vWf)) en sICAM (hoofdstuk 6) waren lager in de eiwitgroep aan het eind van de

\section{Samenvatting}


interventie in vergelijking tot de maltodextrinegroep. Dit suggereert dat ED was verbeterd na 4 weken inname van het eiwitmengsel. Ondanks de significant grotere zuurbelasting als gevolg van het eiwitdieet, vonden we in onze onderzoekspopulatie met gezonde nierfunctie geen nadelige effecten van het eiwitmengsel op de renale hemodynamica in vergelijking tot maltodextrine (hoofdstuk 7).

Om verder uit te zoeken hoe het eiwitmengsel de bloeddruk beïnvloedt, hebben we gedurende 12 uur gevolgd wat met de bloeddruk en bloeddruk-gerelateerde mechanismen gebeurde tijdens 2 extra testdagen in de subgroep van de PROPRESstudie (hoofdstuk 4, 6 en 7). De deelnemers kregen op die dagen drie maaltijden (ontbijt, lunch en avondeten) aangevuld met het eiwitmengsel of met maltodextrine. De bloeddruk daalde significant verder na het eten van de maaltijden met maltodextrine in vergelijking tot de maaltijden met eiwitten. De totale perifere weerstand liet een tendens zien voor een grotere postprandiale daling na de maaltijden met maltodextrine. Dit suggereert dat postprandiale vasodilatatie een rol heeft gespeeld bij het verschil in postprandiale bloeddrukken tussen de maaltijden met maltodextrine en de maaltijden met eiwitten (hoofdstuk 4). We vonden geen duidelijke aanwijzingen voor verschillen in sympathische activiteit (hoofdstuk 4), ED, laaggradige inflammatie (hoofdstuk 6), renine-angiotensinealdosteron-systeem en renale hemodynamica (hoofdstuk 7) tussen de eiwit- en maltodextrinegroep. Wij suggereerden dat de hogere postprandiale insulineconcentraties na de maaltijden met maltodextrine de grotere daling in totale perifere weerstand kan hebben veroorzaakt (hoofdstuk 4). In een tweede studie (hoofdstuk 5) hebben we de hormonale responsen gevolgd gedurende 4 uur na inname van $0.6 \mathrm{~g} / \mathrm{kg}$ van het eiwitmengsel en na inname van $0.6 \mathrm{~g} / \mathrm{kg}$ maltodextrine in een onderzoekspopulatie vergelijkbaar met die van de PROPRESstudie. De verwachting was dat hogere insuline-, GLP-1- en glucagonconcentraties gepaard zouden gaan met grotere NO-afhankelijke vasodilatatie. Ook in deze studie veroorzaakte inname van maltodextrine een grotere postprandiale bloeddrukdaling en een grotere postprandiale stijging van insuline. Echter, inname van het eiwitmengsel veroorzaakte de hoogste postprandiale concentraties van GLP-1, glucagon en nitriet, nitroso compounds (RXNO) en S-nitrosothiols (NOx). Dit suggereert dat de grotere bloeddrukdaling na inname van maltodextrine niet via NOafhankelijke vasodilatatie is geschied.

De chronische effecten van 4 weken verhoogde eiwitinname op de bloeddruk in vergelijking tot maltodextrine-inname verschilden van de postprandiale effecten van het eiwitmengsel en van maltodextrine. Het eiwitmengsel verlaagde de bloeddruk op de lange termijn ten opzichte van maltodextrine, maar de postprandiale bloeddruk werd juist meer verlaagd na inname van maltodextrine. Deze bevinding suggereert dat postprandiale responsen als gevolg van eiwitinname niet direct de effecten van lange termijn inname kunnen voorspellen. Daarnaast kunnen verschillende bloeddrukregulerende mechanismen 
een rol spelen bij de postprandiale effecten en bij de lange termijn effecten van verhoogde eiwitinname.

Om het effect van voedingseiwitten op bloeddrukregulatie verder uit te zoeken hebben we 4-uur postprandiale responsen na de inname van $0.6 \mathrm{~g} / \mathrm{kg}$ erwteneiwit, melkeiwit en kippenei-eiwit met elkaar vergeleken (hoofdstuk 5 en 6). Kippenei-eiwit veroorzaakte een significant grotere stijging in bloeddruk in vergelijking met de andere twee eiwitten. Daarnaast veroorzaakte kippenei-eiwit de kleinste stijging van insuline- en glucagonconcentraties en de kleinste daling van de augmentation index (Alx) vergeleken met melk- en erwteneiwit. Inname van het erwteneiwit veroorzaakte de grootste stijging van glucagon en NOx concentraties. Deze bevindingen suggereren dat erwteneiwit een lagere postprandiale bloeddruk veroorzaakte in vergelijking met kippenei-eiwit als gevolg van hogere insuline- en glucagonconcentraties, welke een grotere NO-afhankelijke vasodilatatie kunnen teweegbrengen. Melkeiwit veroorzaakte een lagere postprandiale bloeddruk dan kippenei-eiwit via NO-onafhankelijke mechanismen, omdat NOx concentraties vergelijkbaar waren tussen kippenei-eiwit en melkeiwit. Onze bevindingen suggereren dat voedingseiwitten afkomstig van verschillende voedselbronnen verschillende effecten op de bloeddruk hebben. Toekomstige studies moeten zich richten op lange termijn effecten van deze eiwitbronnen op de bloeddruk, omdat we de lange termijn effecten niet kunnen voorspellen uit onze postprandiale studies. Daarnaast dienen nog twee andere vragen te worden beantwoord: "is het effect van verhoogde eiwitinname op bloeddruk een gevolg van de grotere eiwitinname of van de lagere koolhydraatinname?" en "verbetert het eiwitmengsel de bloeddruk ook over een periode langer dan 4 weken in vergelijking tot maltodextrine zonder negatieve effecten op nierfunctie?" 
Valorization 


\section{MAIN GOAL OF VALORIZATION}

Valorization is defined by the National Volarization Committee as "the process of creating value from knowledge, by making knowledge suitable and/or available for social (and/or economic) use and by making knowledge suitable for translation into competitive products, services, processes and new commercial activities". In other words: "How can the finding that 4 weeks consumption of a protein mix lowers blood pressure (BP) be translated into practice?" The first question that needs to be addressed is the societal relevance of this finding. The next question is what extra knowledge do we need, before this finding can be translated into practice? Followed by addressing how this knowledge, when sufficient, can be translated into practice.

\section{SOCIETAL AND ECONOMIC RELEVANCE}

Increased BP is an important risk factor, which frequently goes together with other disease risk factors like obesity and hyperinsulinemia in the metabolic syndrome. The metabolic syndrome often leads to cardiovascular diseases (CVD) or type 2 diabetes (1). In a randomized controlled trial comparing effects of 4 weeks of increased protein intake $(3 \mathrm{x}$ $20 \mathrm{~g}$ per day) with maltodextrin intake ( $3 \times 20 \mathrm{~g}$ per day) on BP, we found a decrease of 4.9 $\mathrm{mmHg}$ systolic blood pressure (SBP) after 4 weeks on a high protein diet (chapter 3 ). A decrease of this magnitude at the population level would lead to a $14 \%$ risk reduction of stroke mortality and $9 \%$ risk reduction in coronary heart disease mortality (2). Population wide reductions of diastolic blood pressure (DBP) could also reduce the risk of stroke, transient ischemic attacks, and coronary heart disease (2). This would have a great societal impact, since CVD are the second largest cause of death in the Netherlands (3). This would also reduce medical costs of surgery, revalidation, and medication. Reduction of BP by means of a healthy lifestyle could also postpone the need for antihypertensive medication use, which also saves medication costs.

\section{IS CURRENT KNOWLEDGE SUFFICIENT TO IMPLEMENT A DIETARY ADVICE?}

Before a dietary advice can be implemented, it is of importance to assess the risk-tobenefit ratio for specific target groups. Regarding BP the benefits of increased protein intake have been shown for mixes of dietary proteins, protein-rich diets and for several protein-rich food substances. Dietary proteins also improve adiposity and triglyceride levels, but small beneficial effects need to be evaluated against potential harms (4). It is still not clear whether all types of proteins and protein-rich foods are beneficial for health. Some types of proteins may have adverse effects on BP, for instance via adverse effects on kidney function. In addition, other risks of protein consumption also need to be 
considered, like the potentially increased risk of cancer reported recently (5). Therefore, the time may not be right yet for the implementation of a general dietary advice to increase protein intake. Further research is necessary and future research should concentrate on long-term effects (beyond 4 weeks) of dietary proteins on BP and other health issues. Although randomized trials do not suggest a difference in the BP-lowering effects of plant and animal proteins, animal proteins are suggested to increase the risk of cancer in individuals between the ages of 50-65 years old (5).Therefore, plant proteins may be the most promising proteins regarding risk-to-benefit ratios. Increasing the intake of plant proteins is also more attractive from a economical and ecological point of view, because animal proteins are more expensive to produce and production of animal proteins goes together with more environmental pollution. Because the risk of cancer from high protein intake differs between age-groups (5), it is of importance to investigate the risk-to-benefit ratios in different age groups. Different patient groups may also have different risk-to-benefit ratios for increased protein intake. For instance, individuals with impaired kidney function or a higher risk for impaired kidney function (like type 2 diabetics), could have an adverse risk-to-benefit ratio of increased protein intake compared to individuals without (an increased risk of) impaired renal function. Therefore, risk-to-benefit ratios need to be assessed for different types of populations.The development of biomarkers to identify the individuals who would benefit from the BPlowering effect of dietary proteins would also be a nice approach. We did not find differences in biomarkers of endothelial dysfunction (ED) postprandially, whereas we did find that ED and pulse wave velocity were improved after 4 weeks on the high protein diet. Perhaps other markers, which we did not measure, are able to predict whether an individual would show an improvement in ED and BP in the long-term.

\section{PARTIES THAT SHOULD BE INVOLVED IN NEW RESEARCH PROJECTS}

\section{Academia}

Academia have a good insight into existing knowledge and with this knowledge they can come up with new studies, which add information to existing evidence. Academia have knowledge on physiological risks and benefits of certain foods for certain populations and they can translate current knowledge from scientific publications to choose the most promising product to test. Also, academia know how to plan a scientifically sound study design and academia have state-of-the-art facilities for conducting independent objective research. Academia are also experts in objectively publishing research findings in the academic world, which drives other research groups to use their expertise and facilities for further investigation to further broaden current knowledge. 
Statisticians should also add to the research proposal to make sure that the study is designed in such a way that data can be analyzed in the best possible way.

Funding for the research can be obtained from industrial companies and/or from research organizations like the Hartstichting. It is important to keep valorization in mind when planning research.

\section{Industry}

The present research was a part of research project A-1003 funded by top institute food and nutrition (TIFN). TIFN is a public-private partnership of science, industry and government conducting strategic research in food and nutrition. Such collaboration is essential for optimal valorization of research. Research scientists are supposed to be the objective party bringing the knowledge to conduct a promising study, while the industry brings in practical use of research and translation into products that can be marketed. For instance, researcher may be very interested to find out how a certain bioactive food component reduces BP, whereas this particular food component may not be of interest for industry because of the costs to isolate this component.

Industries keep an eye on the innovative and practical parts of the research. Is the product already patented? Can we patent it in the future if proven beneficial? Is the product we choose to test easy to obtain? What are the costs? Can the product be produced in a tasty edible form? Do they weigh up against the health/economical benefits?

\section{Health care specialists}

Disciplines like dietitians and general practioners should also be involved in the development of new research projects. These health care specialist have expertise on how to motivate participants to take the test product according to the prescription. They also know what challenges are to be expected when supplements are used as opposed to whole foods. And these disciplines have experience to design the research in such a way that dietary compliance is optimized. Their experience is also valuable to design the research within the boundaries of daily practice. Strictly controlled diets with researchers providing food are a good way to proof a principle but are too intensive to be feasible for daily practice. Because the BP-lowering effect of dietary proteins has been shown many times, now it is time to conduct research controlled within the boundaries of daily practicioners. In this way, results can be generalized better and the step towards implementation of a dietary advice is also smaller. 


\section{TARGET GROUPS FOR IMPLEMENTATION OF AN INCREASED PROTEIN DIET}

If follow-up studies show that the risk-to-benefit ratio of increased intake of certain proteins is beneficial for the health of specific patient groups, the time is right to start with the implementation of a dietary advice. To make sure that knowledge obtained from our studies is put to good use, it is important to inform as many groups of stakeholders as possible to spread the knowledge. Several target groups are interested in our study results.

\section{Patients}

Individuals with elevated BP and patient organizations would be interested in our study results. Individuals with elevated BP could profit from an increased protein diet. Because studies are based on research populations, it is not certain that all individuals with elevated blood pressure would profit from a high protein diet. But those who are able to lower their BP may lower their risk for CVD. In addition, BP lowering medication might be reduced, which also reduces the burden of medication use and drug reactions. Patients could also have lower expenses because in the Netherlands everyone is obliged to pay for the first 350 euros of health care costs themselves. Some of our research participants were against the use of medication and were very interested in dietary approaches to reduce their $\mathrm{BP}$.

\section{Health care professionals}

Evidence-based practice is an important part of health care practice theses days. Because general practioners, dietitians, life style coaches etcetera want the best for their patients/clients they would be interested in implementing a new dietary advice.

\section{Industry and entrepreneurs}

Companies would be interested in our research findings. For the present study, the finding that dietary protein lowers BP does not lead to a patent because dietary protein is freely available on the market. However, in the future health claims could be added to proteinrich products to convince consumers to buy these products. These health claims could also help health care professionals, like dietitians and general practioners, providing dietary advice to individuals with elevated BP.

\section{Media}

Media reporting news on health care are also a target group that needs to be considered. The Maastricht University press-bureau for scientific communication can assist scientists in writing a scientifically sound press release to inform the media. Our paper in chapter 3 
received media attention. Working together with a professional of media communication could have helped us with managing media attention and using the media efficiently for carrying out the main message from our research.

\section{Policy makers}

One target group is the Dutch Health Council, which is an independent scientific advisory organ who gives advice to the Dutch government on public health. Another important target group is the Dutch Food center, which informs the Dutch population on healthy nutrition. In addition, the European Society of Hypertension (ESH) and European Society of Cardiology (ESC) could be informed to implement a high protein diet in their guidelines for the treatment of hypertension.

\section{APPROACH FOR IMPLEMENTATION OF AN INCREASED PROTEIN DIET}

\section{Create a solid dietary advice}

A multidisciplinary approach is necessary to create a solid dietary advice for patients. Health care professionals have experience with advising dietary regimens and can contribute to finding the best way to successfully increase protein intake of patients/clients. Health sciences graduates in the field of health promotion can also advise on how to make an appealing and clear leaflet for patients and for health care professionals on the dietary advise. A contact number/email should be put on the leaflet to help patients and health care professionals when they have questions about the diet.

How to reach the target groups

Collaboration with authorities involved in providing dietary advice to consumers and health care professionals like the Dutch Food center. In addition, Information could also be provided to healthcare professionals at congresses and symposia, like "arts en voeding", via occupational websites like www.nieuwsvoordietisten.nl, and via schools and education.

Large groups of people can be reached by showing up in public debates, television interviews, interviews for popular magazines read by target groups. Many magazines targeting men and women of different age groups also have a health column.

The most important thing is to not sit and wait until you are contacted. A communications professional should be assigned to manage information provision. This professional can identify the most important communication channels to start with and may also be a good spokes person to show up in the media. 
To reach a greater audience scientific findings should be published in open access journals. But to reach a non-scientific public articles in national newspapers could be a better medium.

Social media are also an efficient way to reach many persons in a short time. Many companies nowadays have Linkedin, Twitter and Facebook accounts with lots of followers.

\section{Industrial products}

Even though dietary proteins are commercially available, entrepreneurs may be interested in developing for instance a protein bar for lowering BP. But a health claim could also help to sell existing protein-rich products. If a protein-rich diet becomes hype perhaps the market had place for restaurants serving only protein-rich products.

\section{Follow up of implementation}

Health care professionals can also be involved in follow-up of dietary advises to monitor beneficial and adverse health effects in the long term. National research bureaus like central bureau of statistics (CBS) or the national institute for public health and environment (RIVM) could also help in monitoring health developments of patients in the longer term. If implementation is successful in the Netherlands, the advice could be extended by involving the World Health Organization. 


\section{REFERENCES}

1. Wiernsperger N, Nivoit P, De Aguiar LG, Bouskela E. Microcirculation and the metabolic syndrome. Microcirculation. 2007;14(4-5):403-38.

2. Whelton PK, He J, Appel LJ, Cutler JA, Havas S, Kotchen TA, et al. Primary prevention of hypertension: clinical and public health advisory from The National High Blood Pressure Education Program. Jama. 2002;288(15):1882-8.

3. Vaartjes I, Koopman C, van Dis I, Visseren FL, Bots ML. Hart- en vaatziekten in Nederland 2013, cijfers over leefstijl, risicofactoren, ziekte en sterfte. 2013. Available from: https://http://www.hartstichting.nl/downloads/cijferboek-2013.

4. Santesso N, Akl EA, Bianchi M, Mente A, Mustafa R, Heels-Ansdell D, et al. Effects of higher- versus lower-protein diets on health outcomes: a systematic review and meta-analysis. Eur J Clin Nutr. 2012;66(7):780-8.

5. Levine ME, Suarez JA, Brandhorst S, Balasubramanian P, Cheng CW, Madia F, et al. Low Protein Intake Is Associated with a Major Reduction in IGF-1, Cancer, and Overall Mortality in the 65 and Younger but Not Older Population. Cell metabolism. 2014;19(3):407-17. 


\section{Dankwoord}

Acknowledgements 
Vele mensen hebben bijgedragen aan de totstandkoming van dit proefschrift. Bij deze wil ik graag iedereen bedanken die, op welke manier dan ook, betrokken is geweest. Bedankt allemaal!

Allereerst zou ik graag mijn promotoren Marleen van Baak en Peter de Leeuw willen bedanken voor al hun steun en vertrouwen bij het schrijven van mijn thesis. Marleen, ik vond het heel plezierig om voor jou te werken en heb het idee dat ik bij jou altijd 'mijn ei' kwijt kon zowel met betrekking tot praktische zaken als privézaken. Ik heb het als zeer prettig ervaren dat je altijd snel was met nakijken zodat ik weer verder kon met schrijven. Peter, bedankt voor je kritische en klinische blik op mijn thesis.

I would also like to thank the members of the assessment committee. Prof. dr. R.P. Mensink, prof. dr. H.A.J. Struijker Boudier, prof. I.A. Macdonald, and dr. P. Zock thank you for reviewing my thesis.

Lieve Janneke, jij hebt letterlijk bloed, zweet en tranen gestopt in de uitvoering van de PROPRES en AAPRES studie. Een beter organisatietalent hadden we ons niet kunnen wensen. Ik heb zoveel van jou geleerd vanaf het moment dat ik als masterstagiaire begon op de PROPRES studie tot aan het moment dat we beiden als PhD-studenten werkten bij Marleen. Als werkende moeder ben je ook één van mijn voorbeelden. Ik vind het zo knap hoe jij tijdens de PROPRES en AAPRES studie je werk en privéleven hebt weten te balanceren. Ik wil je bedanken voor het vertrouwen dat je in mij hebt gesteld, waardoor ik als stagiaire/onderzoeksassistent aan alle metingen mee heb mogen werken. En natuurlijk ook voor je vertrouwen dat ik de resultaten van deze mooie studies heb mogen opschrijven.

Uiteraard waren de PROPRES en AAPRES studie niet mogelijk geweest zonder enthousiaste proefpersonen. Bij deze wil ik alle proefpersonen bedanken voor hun bijdrage aan deze studies.

Met veel plezier denk ik terug aan mijn PROPRES-tijd waar ik heb samengewerkt met Janneke, Harry R, Jeroen, Sander O en Frank. Harry R, van jou heb ik geleerd dat je ook met minder voorbereiding, heel veel situaties ad hoc goed op kunt lossen! Bedankt daarvoor. Janneke, Harry R, Thijs, Frank, Imco en Floor bedankt voor jullie werk op de AAPRES studie. 
Graag wil ik ook alle betrokkenen bij het project A1003 bij TIFN bedanken. Lisette, Stephan en Marianne bedankt voor jullie suggesties voor mijn artikelen. Ik werd altijd heel blij van jullie enthousiaste en snelle commentaren. Jan bedankt voor je statistische ondersteuning en Casper bedankt voor je input bij het endotheelfunctie artikel. Mijn mede-aio's Wieke, Else en Susanne, ik vond het leuk om met jullie samen te werken. Wieke en Else, na jullie promoties heb ik de eer om met mijn promotie het A1003 project af te sluiten. Susanne, jij bent net als ik later in het A1003-bootje gestapt. Veel succes met het afronden van je promotie.

Eveline en Brenda, wat ben ik trots dat jullie als mijn paranimfen naast me staan. We kennen elkaar al van onze studietijd, maar zijn pas echt met elkaar opgetrokken toen we collega's zijn geworden. Het is bijzonder dat we alle drie ongeveer tegelijkertijd zijn begonnen met promoveren en daardoor ondanks heel verschillende studies veel hebben kunnen delen. Samen met Dorit hebben we heel wat stoom afgeblazen tijdens onze talloze gezellige lunches. Bij jullie kon ik altijd terecht met problemen of voor motivationele speeches. Maar ook buiten het werk hebben we de nodige inspanning (skaten met Brenda) en ontspanning (Carcassonne met Eveline, samen eten) met elkaar gedeeld. Brenda, om jouw droge gevoel voor humor kan ik erg lachen $(;)$. Daarnaast waardeer ik ook je bakkunsten waar ik vaak van mee mocht genieten. Zo vaak zelfs dat je kamergenoten dachten "daar komt ze weer om te eten". Eveline, ondanks onze verschillende interesses kunnen we altijd gezellig kletsen over van alles en nog wat. Jij bent een echte bezige bij en toch weet je altijd wel tijd vrij te maken om samen af te spreken. Ik ben zeer vereerd dat ik jouw paranimf mag zijn, zodat ik nog een kijkje achter de schermen kan nemen voordat mijn eigen 'grote dag' aanbreekt.

Zonder mijn kamergenoten, Jos en Dorit, zouden mijn werkdagen een stuk saaier zijn geweest. Onze discussies over goede manieren, de deur afsluiten, het inrichten van onze kamer en elastiekgevechten ga ik wel missen. Jos, als ik aan HB denk, denk ik meteen aan jou. Jij bent er altijd en staat altijd (soms onder protest ;-D ) voor iedereen klaar. Dorit, met jou kon ik alles delen. Jij staat altijd klaar om te helpen met bijvoorbeeld het nakijken van belangrijke e-mails of om presentaties te oefenen. Van jouw humane kijk op gezondheidsonderzoek, ten opzichte van mijn fysiologische blik, heb ik veel geleerd.

Ook Bianca, Els, Roel, Nadia, Laura, Jeroen, Daisy, Dennis, Chantalle en mijn exkamergenoten Janneke, Anouk en Jasper wil ik bedanken voor de gezellige koffie/lunch/klets pauzes tussen het werk door. Chantalle, ik vond het een bijzondere ervaring om als jouw paranimf het hele traject van promoveren al een keer van achter de schermen te mogen zien. 
Uit de verschillende werk/vetstof/literatuur overleggen heb ik veel geleerd van Marleen, Dorit, Erik, Roel, Nadia, Laura, Ellen B, Ellen K, Anneke, Annemieke, Yvonne, Chantalle, Dorien, Jasper, Emanuel, Max, Rudi, Birgitta, Gijs, Johan J, Judith en Nicole.

Natuurlijk mag ik alle mensen die me met raad en daad hebben bijgestaan bij het uitvoeren van experimenten met vetbiopten en gekweekte SGBS vetcellen niet vergeten: Wim S, Ellen K, Jasper, Roel, Jos, Wendy, Freek, Johan J, Yvonne, Nicole, Gijs, Johan R, Anja, Erik, en Bram. Uiteraard wil ik ook de proefpersonen van COEUR en van de trainingsstudie bedanken voor hun bereidheid om een vetbiopt af te staan voor mijn experimenten.

Harry F, thanks for your help with my experiments. You took a lot of work out of my hands so that I was able to concentrate on writing the articles to finish my thesis.

Claudia, Desiree en Yolanda, jullie wil ik graag bedanken voor jullie interesse en hulp met het regelen van allerlei zaken rondom mijn werk en de promotie. Loek, wanneer SPSS me in de steek liet, was jij altijd met de oplossing in de buurt.

Ook mijn nieuwe collega's van het hart en vaatcentrum in het MUMC+ mag ik niet vergeten. Ik ga niet iedereen noemen, maar mijn directe BIM collega's Gitte, Helma, Paul $B$, Tom en Wim D wil ik speciaal bedanken voor een gezellige werksfeer en ik hoop dat we nog lang plezierig kunnen samenwerken.

Lieve vrienden en familie, aan jullie natuurlijk ook mijn dank voor jullie onuitputtelijke interesse in mijn onderzoek en het verzorgen van leuke afleiding tijdens mijn vrije dagen.

Pap en mam, zonder jullie had ik hier niet gestaan. Jullie hebben me altijd gesteund en achter me gestaan met alles wat ik doe. Bij jullie kan ik altijd met alles terecht of het nou is voor advies, om mijn hart te luchten of om op het laatste moment mee te eten, dat maakt jullie niet uit. Bedankt voor al jullie interesse en vertrouwen.

Mijn schoonouders, Ger en Gertie, jullie zijn als een tweede ouderlijk huis voor mij.

Bedankt voor al jullie steun en interesse. Familiebezoekjes met Vienna, Jorinda, Melanie, Sander J, Dylan, Keanan en Kristan zorgen altijd voor gezellige ontspanning.

Graag wil ik Ger en Gertie, pap en mam en Melanie bedanken voor het oppassen op Stijn. Zonder jullie was mijn boekje lang niet zo snel afgekomen! 
De twee belangrijkste mannen in mijn leven, Paul en Stijn. Paul, jij hebt altijd het volste vertrouwen gehad dat ik mijn promotie tot een goed einde kan brengen. Je hebt me met Stijn altijd de ruimte gegeven om mijn werk goed af te ronden. Bedankt voor je onvoorwaardelijke steun en interesse en voor je hulp bij het maken van de cover. Lieve Stijn, jij hebt van het laatste jaar van mijn promotie echt een feestje gemaakt. Na een dag werken is het altijd heerlijk thuiskomen als ik jou weer zie met je grote blauwe ogen en je brede lach :-D 

Curriculum vitae 


\section{CURRICULUM VITAE}

Karianna Francisca Maria Beekman was born on February $17^{\text {th }}, 1983$ in Cadier en Keer, the Netherlands. She completed secondary school at SG Groenewald in Stein in 2001. From 2001-2004, she studied occupational therapy at Hogeschool Zuyd in Heerlen, but she decided to switch towards scientific education and started with "health sciences" at Maastricht University in 2005. In 2009, she graduated cum laude as Master of "physical activity and health: metabolism and nutrition" at Maastricht University. Her internship was spent on the PROtein and blood PRESsure (PROPRES) project under supervision of Marleen van Baak and Peter de Leeuw. Her Master thesis was about the postprandial effects of protein supplementation on blood pressure and arterial stiffness. Since 2010, Karianna worked as a PhD student under supervision of Marleen van Baak at the department of Human Biology at Maastricht University. She worked on the project: " $\beta_{2}$ adrenergic sensitivity in obesity". In 2011, she started to write articles about findings in the PROPRES study. These articles, which describe two studies on effects of dietary proteins on blood pressure, are described in her thesis. In September 2014, she started working as datamanager at the cardiovascular center of Maastricht University Medical Centre in Maastricht. 
List of publications 


\section{PUBLISHED MANUSCRIPTS}

Teunissen-Beekman KFM, Dopheide J, Geleijnse JM, Bakker SJ, Brink EJ, de Leeuw PW, van Baak MA. Protein supplementation lowers blood pressure in overweight adults: effect of dietary proteins on blood pressure (PROPRES), a randomized trial. Am J Clin Nutr. 2012;95(4):966-71.

Teunissen-Beekman KFM, van Baak MA. The role of dietary protein in blood pressure regulation. Curr Opin Lipidol. 2013;24(1):65-70.

Teunissen-Beekman KFM, Dopheide J, Geleijnse JM, Bakker SJ, Brink EJ, de Leeuw PW, Serroyen J, van Baak MA. Blood pressure decreases more after high-carbohydrate meals than after high-protein meals in overweight adults with elevated blood pressure, but there is no difference after 4 weeks of consuming a carbohydrate-rich or protein-rich diet. J Nutr. 2013;143(4):424-9.

Teunissen-Beekman KFM, Dopheide J, Geleijnse JM, Bakker SJ, Brink EJ, de Leeuw PW, Serroyen J, van Baak MA. Differential effects of proteins and carbohydrates on postprandial blood pressure-related responses. Br J Nutr. 2014;112:600-8.

\section{MANUSCRIPTS IN PREPARATION}

Teunissen-Beekman KFM, Dopheide J, Geleijnse JM, Bakker SJ, Brink EJ, de Leeuw PW, Schalkwijk CG, van Baak MA.Effects of dietary proteins and carbohydrates on markers of endothelial function and low-grade inflammation. In preparation

Teunissen-Beekman KFM, Dopheide J, Geleijnse JM, Bakker SJ, Brink EJ, de Leeuw PW, van Baak MA. Effect of increased protein intake on renal acid load and renal hemodynamic responses. Submitted 

